GEOLOGY OF HARRISON AND MONONA COUNTIES

BY

B. SHIMEK 



\section{E R R A T A}

P. 309-First line at top, read XXIV in place of XXXI.

P. 349-Plate XXVIII, Figure 2.-The inscription for Figure 2 (B), reads as if the calcareous plates had been folded after formation. They were evidently formed on a folded surface.

P. 395-Sixth line from top, read 30 in place of 31.

P. 415-Tenth line from bottom; read XXXV in place of XXV.

P. 466-Fourteenth line from bottom, read 47 instead of 49 .

P. 475-Seventeenth line from bottom, after "first grove" insert: (See Plate XXXV, Figure I.).

P. 484-Tenth line from bottom, substitute H. A. Kinney for M. S. Kinney. 
$P \operatorname{con} r \quad p a g_{e}$ faces $p .273$

$$
(4.20)
$$




\title{
GEOLOGY OF HARRISON AND MONONA COUNTIES
}

\author{
BY B. SHIMEK
}

CONTENTS

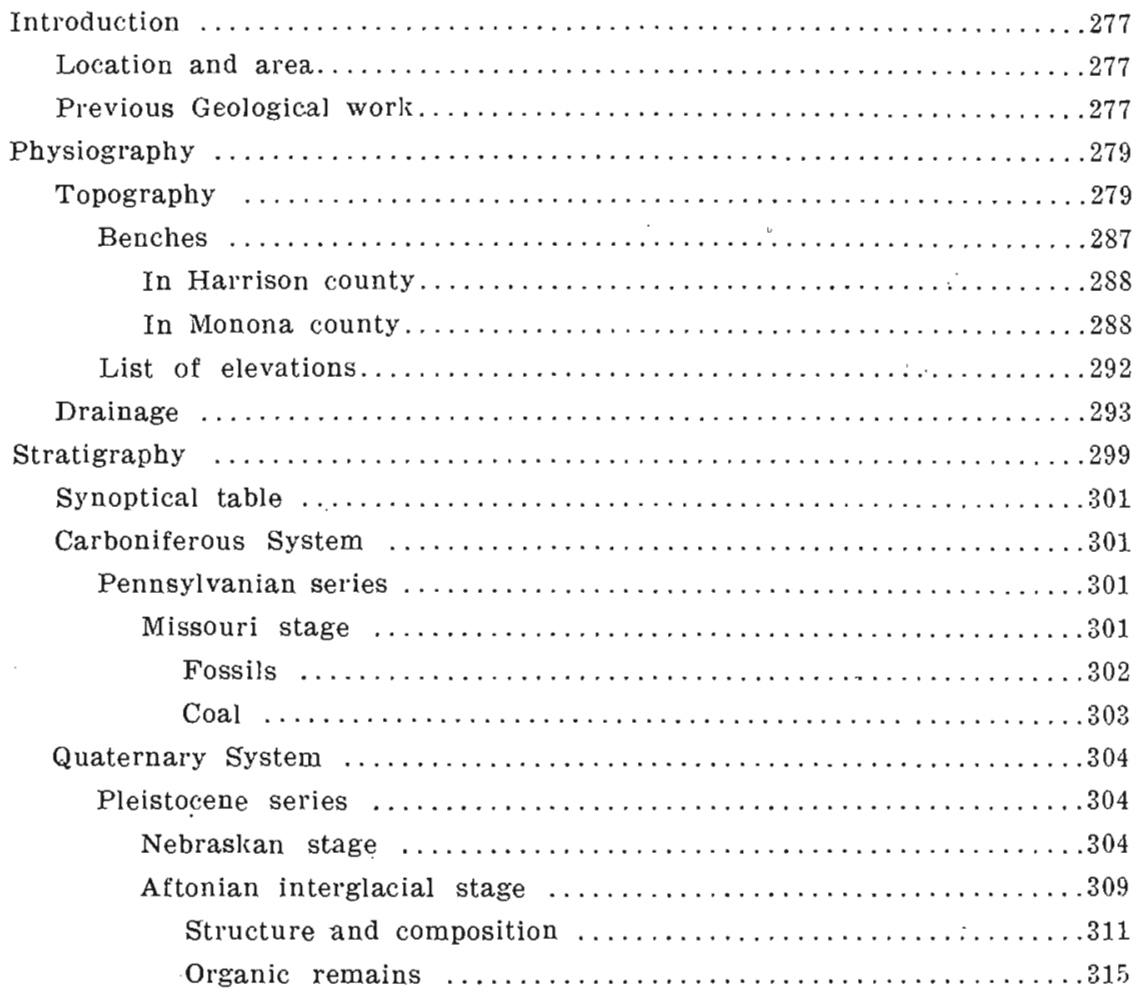




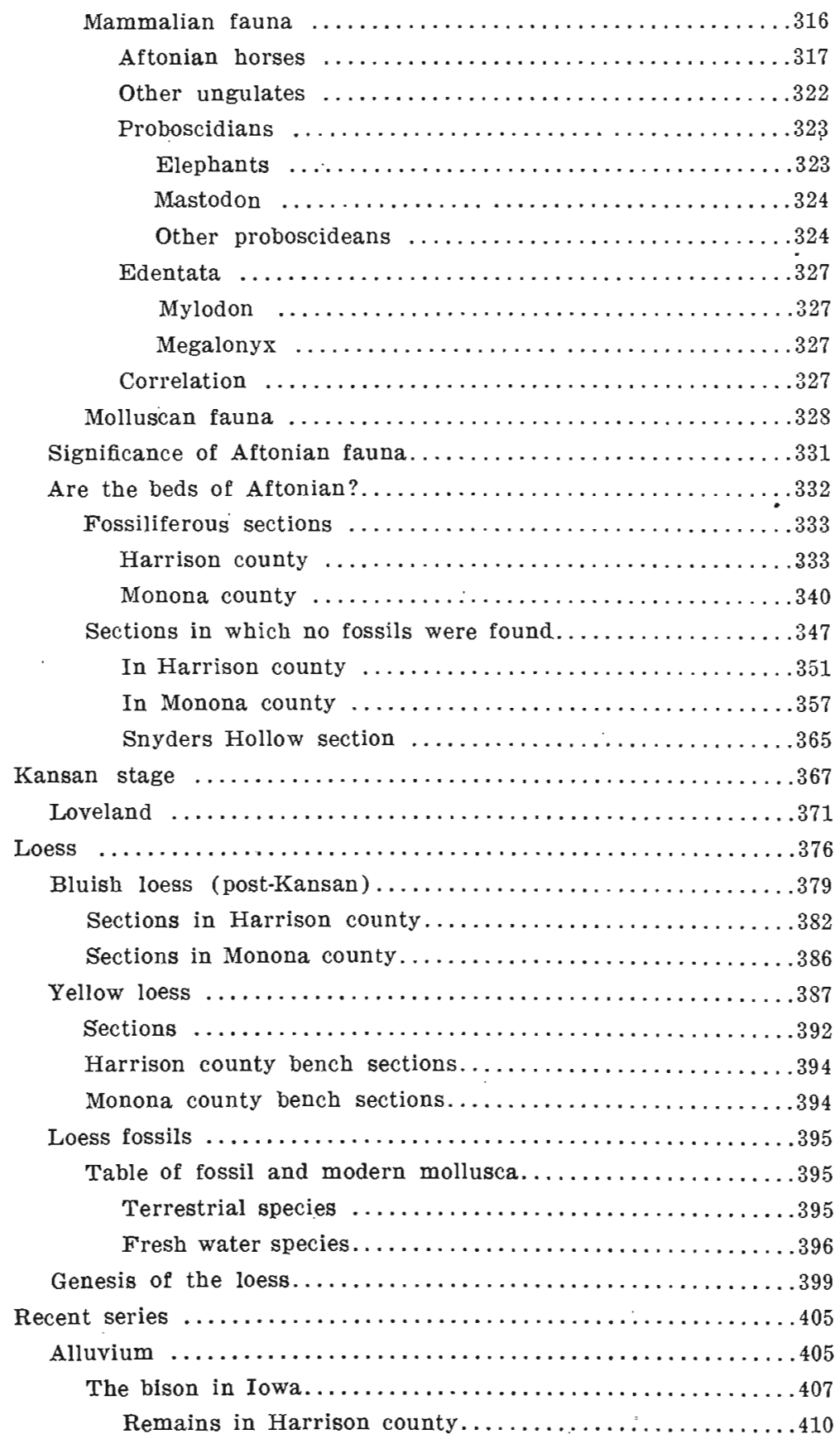


Remains in Monona county.................. 410

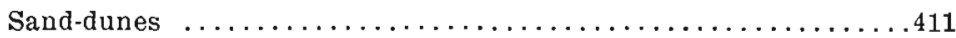

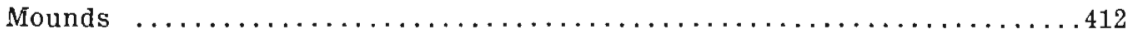

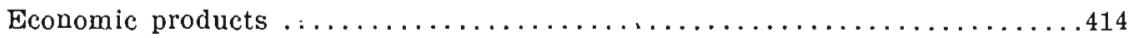

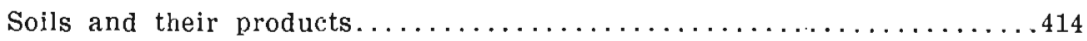

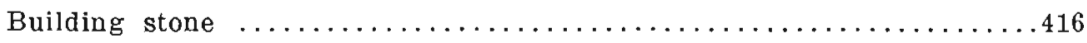

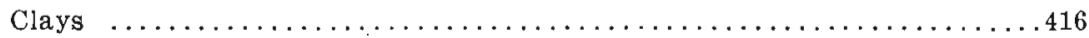

Sand and gravel.............................. 417

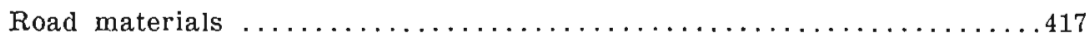

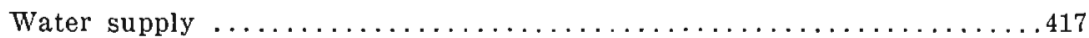

Watel power and drainage ditches...................... 418

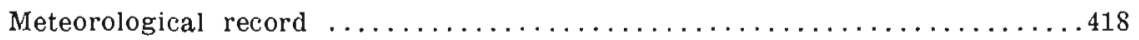

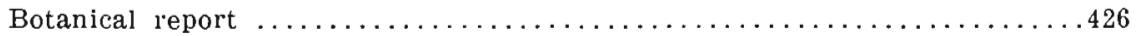

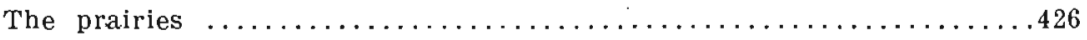

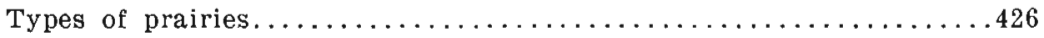

The prairie flora.............................. 430

Plants of dry prailies.........................433

Plants of upland woods......................... 439

Plants of alluvial groves....................... 442

Plants of low grounds, marshes, etc . . . . . . . . . . . . 443

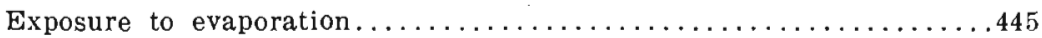

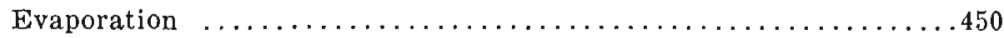

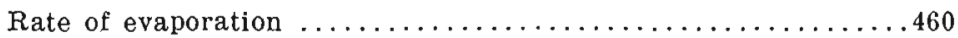

Contributing causes of prairies..................... 471

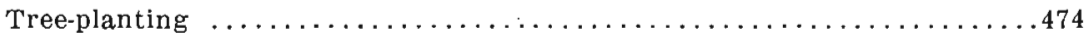

Plants in the Whiting grove....................... 476

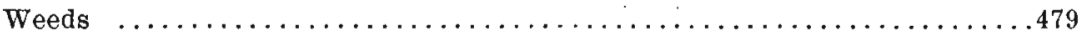

List of weeds and introduced plants.................480

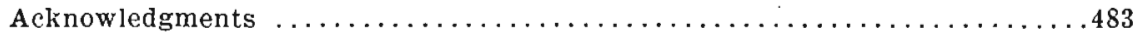




\section{GEOLOGY OF HARRISON AND MONONA COUNTIES}

\section{INTRODUCTION}

LOCATION AND AREA.

Harrison and Monona counties border on the Missouri river, the latter being in the middle east and west tier of counties and the former lying immediately south of it. They adjoin Woodbury county on the north, Crawford and Shelby on the east, and Pottawattamie on the south. Both are irregular in outline, the Missouri river forming their western boundaries, and the east line of Harrison county is broken because the southernmost tier of townships lies south of the correction line.

Harrison county, which was named for President William Henry Harrison, has a superficial area which is a variable quantity on account of the shifting of the Missouri river. It was reported in $1875^{*}$ as "nearly 660 square miles," and in 1888 on the basis of the "latest measurements" as about 697 square miles. $\dagger$ Its present area is probably nearly 690 square miles, of which less than one-fourth is occupied by the Missouri river bottom-lands.

Monona county is said to have been named from Monona, Clayton county, the name having been suggested by the member of the General Assembly from Clayton. Its area is also variable, and for the same reason. It was reported in Andreas' Atlas $\ddagger$ as about 680 square miles, but it is now probably about 690 square miles, of which nearly two-fifths is occupied by the Missouri river alluvial plain.

\section{PREVIOUS GEOLOGICAL WORK.}

Though recent investigations show that this region possesses features of great interest it has not been looked upon with favor by geologists in the past, in part because it was assumed that the

*Andreas' Atlas of Iowa, p. 410.

tJ. H. Smith, History of Harrison County, p. 20.

tOp. clt., p. 409. 
great mantle of loess on the uplands obscures all other features, and in part because the neighboring counties of Woodbury and Pottawattamie had been quite fully studied, and the intermediate region seemed to give little promise of new developments.

The first scientific expedition to visit this territory was that of Lewis and Clark in 1804,-44 years before the first white settler came to Harrison county; and 48 years before the settlement of Monona county. The expedition spent seven days, from August 5 th to 11 th inclusive, along the Missouri river within our limits, and three camps were located in what is now Harrison county, and four in what is now Monona county.*

On April 20, 1820, Thomas Say, who was a member of the Long Expedition, $\dagger$ which had spent the winter almost opposite the south line of Harrison county, ascended Boyer creek in a row boat with a small party to ascertain where it discharges from the bluffs. $\frac{\ddagger}{t}$

In 1870 St. John made a brief report on the surface features and geology of these counties; $\$$ in 1894 Keyes published a brief discussion of the possibility of the occurrence of coal in Harrison county,*** probably based on St. John's report; in 1896 Bain made a brief report on the geology of Woodwarth's (or Woodward's) glen in the northern part of Monona county; $+\dagger$ in 1899 Todd noticed certain Pleistocene and surface features of Harrison county; $\ddagger \ddagger$ in 1901 the writer reported a Pyramidula from the loess of Monona county, $\$$ later discussed and illustrated the sand-dunes of Harrison county, ${ }^{* * *}$ noted certain loess features of the vicinity of Missouri Valley, ${ }^{* * * *}$ and illus-

* See History of the Expedition under the command of Lewis and Clark, republished by Elliott Coues, 1893, Vol. I, pp. 67-72.

tAccount of an Expedition from Pittsburgh to the Rocky Mountains-, under command of Major S. H. Long, U. S. Top. Eng. Compiled by Edwin James, 3 vols., 1823.

IOp. cit., Vol. II, pp. 67-69. They reached the bluffs in the evening, and on the following day walked up the river, evidently to the present site of Logan, for Say records that "at the distance of about five miles, the high grounds closely bounded the creek, and the valley which below is extensive and fertile, disappears." No other point would answer to this description. There can be no question as to the identity of the stream as the Boyer is correctly represented on the map which accompanies the report. Say subsequently described mammals, birds, reptiles, insects and mollusks from the general region, and some of them are specifically credited to "Boyer creek." 186. IIn Whlte's Report on the Geological Survey of the State of Iowa, Vol. II, pp. 175-

* Rep. Iowa Geological Survey, Vol. II, pp. 436-437.

t+Rep. Iowa Geological Survey, Vol. V, p. 280 . 151.

¥\$Bull. U. S. Geol. Survey, No. 158, plate I, and pp. 88, 98, 140, 144, 147; 149 and

88.Bull. Lab. of Natural Hist., State University of Iowa, Vol. V, p. 143.

* Op. cit., Vol. V, part IV, 1904, p. 374, plate XIV, fig. 2.

*** Proc. Iowa Academy of Sciences, Vol, XIV, 1908, pp. 243 and 245. 
trated the bluff topography and sand-dunes of Harrison county;* and in 1907 Beyer and Williams discussed the Carbeniferous of Harrison county and again described the Logan section.**

Preliminary reports on the results of the present survey were also made by Calvin and the writer in papers cited in connection with the discussion of the Aftonian.

\section{PHYSIOGRAPHY Topography}

The topography of Harrison and Monona counties exhibits three distinct features. The greater part of the surface of both counties presents a rolling loess-Kansan contour which is interrupted by a series of valleys of the streams tributary to the Missouri, extending from northeast to southwest and varying in width from one-half to nearly three miles. Over the greater part of this upland area the surface is not too rough for successful cultivation excepting in a few rather restricted inland localities, which probably date their greater roughness from Kansan time, or even earlier.

The most striking examples of these rough areas in Harrison county are found in the northeastern part of La Grange township; the eastern part of Jefferson township and the western part of Cass (Six Mile grove); near the center of Jefferson township (Elk grove); in the southeastern part of Boyer township and the southwestern part of Douglas township (Twelve Mile grove); the region immediately north and west of Logan; Bigler's Grove in Magnolia and Boyer townships; the region northwest of Magnolia (Raglan's grove) in Raglan township; a large part of Allen township; and in a number of less sharply defined areas in Monona county of which the most striking are in the eastern part of Sioux township; the western part of Kennebec township; and the territory northeast of Grant Center. All these latter areas are deeply cut by narrow branching valleys above which the rugged slopes rise very abruptly. It is also a noteworthy fact that these rough areas are marked by the largest native groves of hard-wood trees.

\footnotetext{
*Op. clt.. Vol. XV, 1909, plate III, fig. 2, and plate V, fig. 2.

* Rep. Iowa Geol. Survey, Vol. XVII, pp. 495-496.
} 
The loess bluffs border the Missouri valley throughout its extent in these counties, and are interrupted only by the tributary valleys, which they frequently follow for some distance, especially on the north and west sides. Similar bluffs appear on the opposite side of the valleys wherever a turn in the valley exposes them to the south and west, but usually on the southeast sides of the tributary valleys the bluffs are lower and less abrupt.*

These loess bluffs and ridges form the most striking feature of the topography of this region. They are most prominent along the immediate border of the great valley, gradually descending to the east and finally blending with the rolling loessKansan surface. They present their most striking faces toward the great valley of the Missouri, lowever, and the abrupt slopes rise in sharp contrast from two to three hundred feet above the great flat alluvial plain (see plate XXI, figure 1, and plate XXXI, figure 2) which has been constructed by the restless river whose history is so interestingly written in the geology of the region. In the spring when abundant rains have bathed the rugged slopes an almost uniform green suffuses them; in early summer they are brilliant with loco weed and other flowers; but when summer has advanced, when the rains have ceased and the blistering winds and scorching sun have robbed the southwesterly prairie slopes of their moisture, the sheltered groves and the exposed prairie surfaces stand out in sharp contrast, visible for many miles and setting out with striking effect and unmistakable precision the varied features of this singular topography. The bluffs facing the valley are usually abrupt, though the basal part of the slope is frequently rendered less precipitous by a remnant of a bench which may be traced along almost their entire length. (See plate XXI, figure 1, plate XXIX, figure 1, and plate XXXI, figure 2.) Frequently the bluffs are formed by the abrupt sides of sharp ridges which are parallel with the valley and in that case they are continuous; or they are formed by the ends of a succession of ridges lying

\footnotetext{
* See plate XXII. The bluffs at Pisgah (figure 1) are on the left side of the valley, but their line is here so bent that they face the southwest. They resemble the type which is common on the opposite side of the valley.
} 


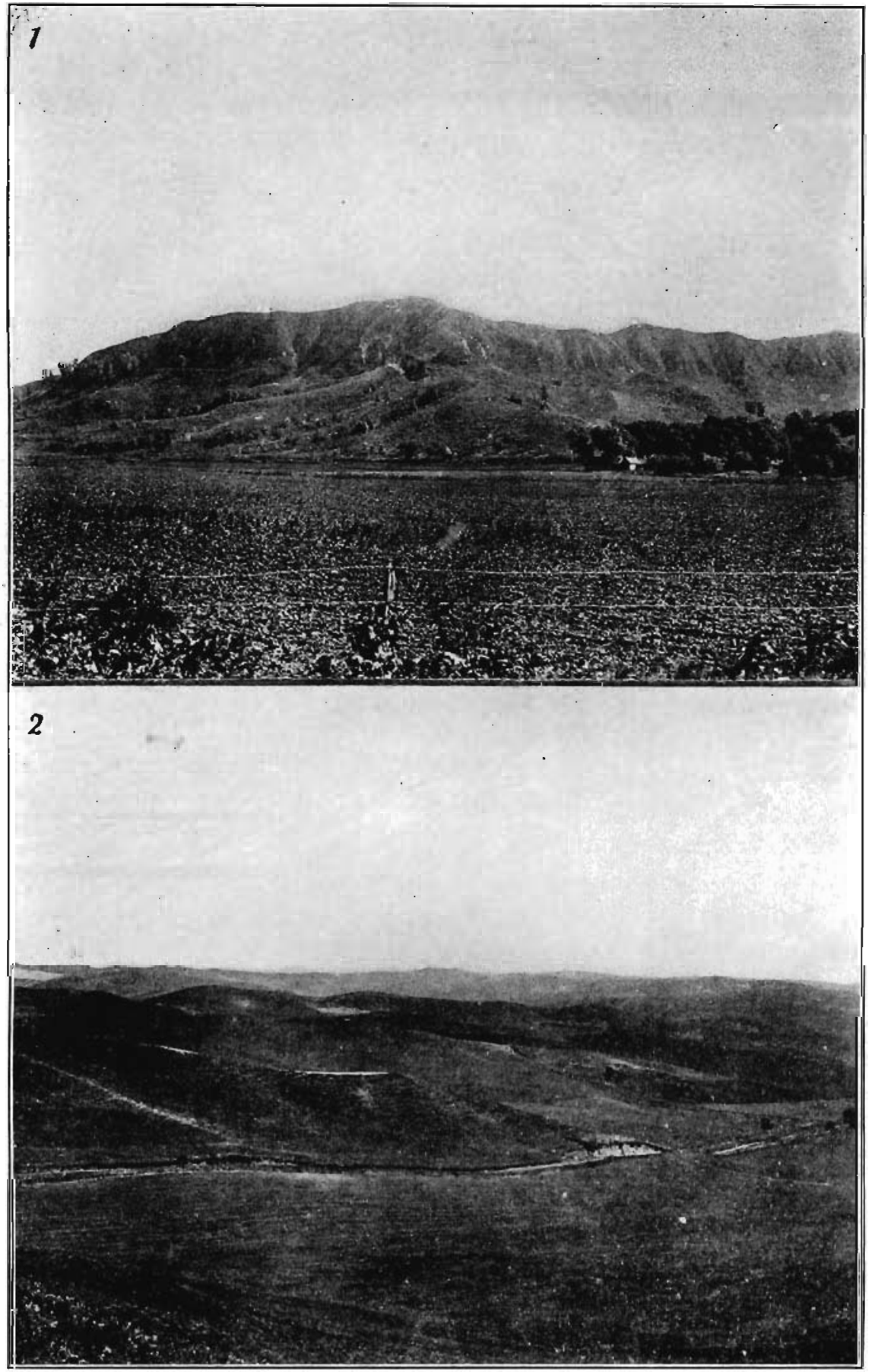

Plate XXI.-Topography in northern Harrison county. (1) Murray Hill, looking northeast (p. 280). (2) Inland topography, looking east from summit of (1) (p 287 ). 
p. $[282]$

(v.20) 
nearly at right angles to the valley and which present an interrupted serrate contour reminding one of distant views of some of the Sierras of the west.

During the day these bluffs may burn in the heat of the midday sun, they may be swept by the hot blasts of summer winds, or hidden in the whirling clouds of yellow dust which are carried up from the bars of the great river; but in the stillness of early morning, and again when the peace and quiet which portend the close of day have settled upon them, they are both restful and inspiring when looked upon from the valley; and there is no grander view in the great Mississippi-Missouri valley than that which is presented under such circumstances from their summits, - on the one hand over the broad valley and on the other across the billowy expanse of the inland loess ridges which appear like the giant swell of a stormy sea which has been suddenly fixed. (See plate XXI, figures 1 and 2.)

This maze of sharp ridges separated by deep valleys has usually been regarded as a result of erosion. White specifically referred to it in these terms, ${ }^{*}$ and this view of their origin has been very generally accepted. It will be shown, however, in the discussion of the loess that the sharpest features of this topography owe their peculiarities to constructional agencies combined with erosion, the former building up the ridges, the latter degrading the valleys. Not infrequently the slopes facing the valley are almost vertical, presenting clear exposures of loess as a result of great slides or faults, which are not unusual during very wet seasons. The oldest settlers report that in the spring of 1859, following an unusually wet year, great masses of the bluff material slipped in this manner. Mr. J. B. P. Day, one of the oldest settlers of Monona county, specifically reports that the principal abrupt exposures along the west side of the Maple valley between Castana and Turin were formed in this manner at that time.

The familiar "cat-steps" which form so conspicuous a feature of the most abrupt loess slopes represent similar action on a smaller scale. It has been sometimes thought that these steps are formed by grazing cattle, but they appear on all the sharper

*Report of the Geological Survey of Iowa, Vol. II, 1870, p. 178. 
loess ridges, especially where exposed to the south and west, and the numerous narrow ledges which characterize this type of topography seem to be the result of successive faulting of masses of the loess, and the cattle have simply taken advantage of the natural paths so provided. It should be especially noted that these "cat-steps" and the very abrupt slopes upon which alone they occur are not ordinarily found on the bluffs bordering the valleys of the larger tributaries of the Missouri on the southeast. It is only where a projecting ridge or a bend in the line of bluffs on this side of the valleys forms an exposure to the south and southwest that we find the slopes marked by the cat-steps which are so frequent on the opposite sides of the valleys. This is strikingly illustrated along the east side of the Soldier in Harrion county in sections 13 and 26, township 81 north, range 44 west, and along the Little Sioux river in Monona county in sections 11 and 14, township 85 north, range 44 west. (See also plate XXII, figure 1.) Cat-steps are almost uniformly present along the main line of the bluffs facing the Missouri river (see plate XXXI, figure 2, and plate XXXIII, figure 1), and for several miles along the tributaries back from the main valley they are also prominent on the west side. They are also more or less well developed on inland loess ridges with a similar southerly exposure. (See plate XXXIV, figure 1.)

These loess bluffs rise to a height of from one hundred and fifty to a little more than three liundred feet above the alluvial plain and present the most unique topography of the entire Mississippi valley; and whether viewed in midsummer with their unequal covering of vegetation, or in the fall when they are tinted a rusty red by the covering of dry blue-joint grass, or in winter when with their mantle of snow they present the aspect of a series of huge snow drifts, they are of unusual interest to the physiographer, the geologist and the botanist, and they will some day be more fully appreciated even by those who are seeking merely material interests.

As already noted these loess bluffs pass eastward into typical rolling Kansan through a series of ridges constantly decreasing: 


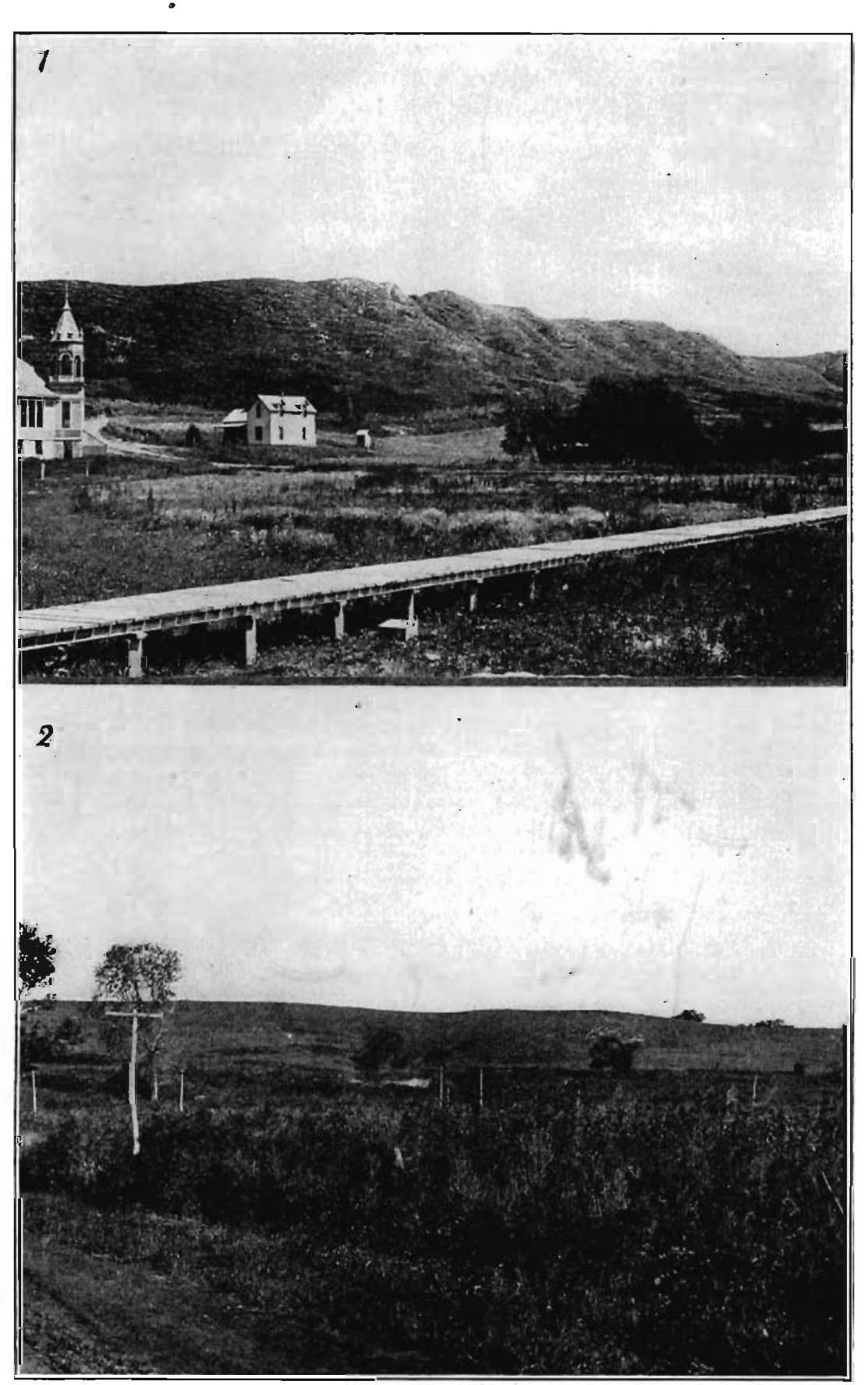

Plate XXII.-Bluffs of tributary valleys. (1) Loess bluffs with cat-steps exposed to southwest. Pisgah, along Soldier (p. 280). (2) Rounded bluffs along the Boyer, south of Cox pit (p. 280 ). 
in abruptness and altitude, the transition usually being complete within two or three miles; though in some cases, as in Raglan, Jackson and Allen townships in Harrison county, and in Sioux, Belvidere and Kennebec townships in Monona county; they extend inland for several miles. The succession of bare sharp ridges and deep valleys form a picture of unusual interest when viewed from the highest points. A bit of this topography is illustrated in plate $X X I$, figure 2, which represents a view looking east from Murray Hill along the boundary between Little Sioux and Jackson townships in Harrison county.

The third of the great topographic regions includes the alluvial plains of the Missouri river and its larger tributaries. The main Missouri alluvial plain varies in width from about five miles near the southern boundary of Harrison county to about eighteen miles in the northern part of Monona county. The Missouri plain slopes to the south, the fall in Monona and Harrison counties being a total of about seventy feet, but there is also a slope of five to six feet from the banks of the Missouri to the flat at the base of the bluffs. It is this fact which accounts for the presence of ponds and small lakes along this edge of the alluvial plain. It also places one of the greatest obstacles in the way of the great drainage projects in which the people of this section are so vitally interested. The difficulty of securing an outlet under such circumstances is obvious.

The tributary streams, like the Little Sioux, Soldier, etc., have likewise formed natural levees which rise from four to five feet above the outlying flats in that portion of the great valley which is subject to frequent overflows, thus exposing these flats to more disastrous floods, and rendering their drainage more difficult after the floods have subsided.

The alluvial plain extends inland along all the larger tributaries of the Missouri, forming flat bottom lands varying, as noted, from one-half to three miles in width. These bottom lands are narrowed in many cases by the encroachment of more or less distinctly developed benches which form a striking feature of the tributary valleys. These benches are narrow or obsolete along the bluffs bordering the great valley, but in the 
lateral valleys they are conspicuous, and form not only the best farming territory, but a safe and convenient location for many of the towns.

The most conspicuous of these benches are located as follows: IN HARRISON CoUnty.

Along the Boyer.-At Dunlap, on both sides of the river, varying in altitude from forty to fifty feet above the river bottom. Dunlap is located on the east bench.

At Woodbine, the town being located on the west bench, which rises thirty-five to forty feet above the valley. On the east side the bench is also conspicuous, especially above Woodbine, and is cut by Picayune creek.

Opposite Willets Siding a prominent bench narrows the valley to about one-lialf mile. This bench reaches a width of more than a mile, and extends along the east side of the valley for more than two miles.

Opposite Logan a bench more than four miles long extends along the east side of the river, and the business part of Logan is situated on the corresponding bench on the west side, which rises sixty to seventy-five feet above the valley. The ridge bordering this bench on the west rises from ninety to 120 feet higher.

Along the west side of the Boyer between Logan and Missouri Valley several smaller benches may be seen.

Along the Willow.-Along the Willow numerous smaller benches appear, perhaps the largest being located in section 27 , township 80 north, range 43 west, on the west side.

Along the Soldier.-In sections 14 and 15 on the west side of the valley, and in 22 and 27 on the east side, township 81 north, range 44 west, distinct benches, which are more or less broken, form a prominent feature.

In sections 1 and 12 of the same township, northeast of Pisgah, benches appear on both sides of the stream.

In Monona Countr.

Along the Soldier.-Between Preparation and Moorhead a bench which reaches fully a mile in width, extends along the east side of the valley for more than three miles. Moorhead is partly located on a narrow bench on the west side. 


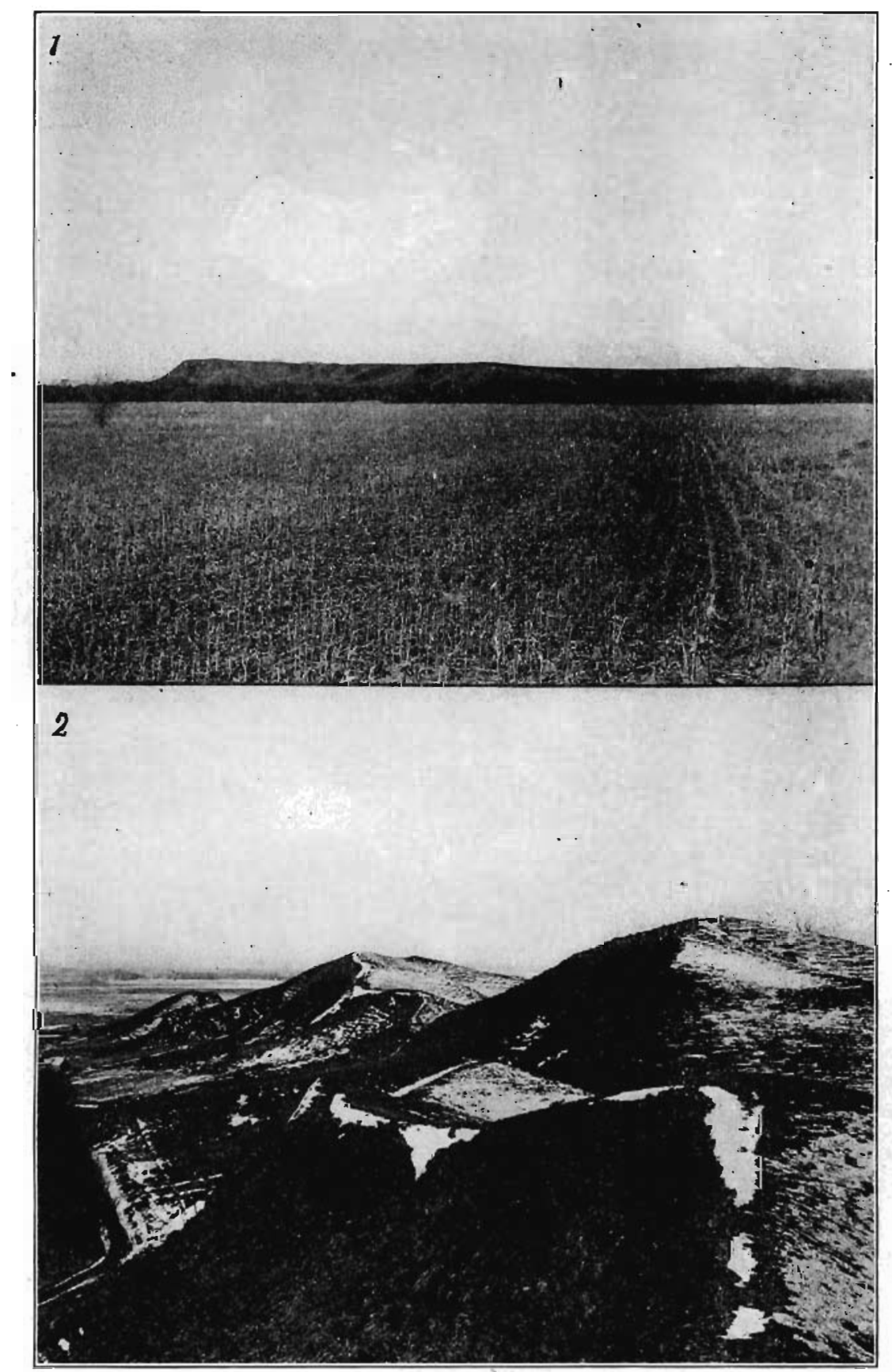

Plate XXIII.-Topography near Turin. (1) Belvidere bench, looking north (p, 291). (2) Loess ridges north of Turin, looking south. Snow on highest points. 
Another of about the same size extends south from Soldier, on the east side. The town of Soldier is located on a smaller bench on the west side.

Between Soldier and Ute smaller, interrupted benches appear on both sides of the river.

Along the Maple.-The finest of these benches, the Belvidere bench, extends along the southeast side of the Maple opposite Turin, for more than three miles. (See plate XXIII, figure 1.) Its upper surface is quite level, and lies about 120 to 130 feet above the valley, rising toward its western extremity, however, to a height of 170 feet and then abruptly descending to the valley. This additional elevation is evidently due to the greater accumulation of loess along the edge lying nearest to the Missouri valley.

Castana also stands on a prominent bench which rises from ninety to 140 feet above the valley. Its finest portion extends northeast from Castana. On the west side a narrow bench extends southward from Castana for about two miles.

Between Castana and Mapleton interrupted benches also appear, especially on the east side of the river.

Mapleton is located on a bench which rises thirty to forty feet above the valley on the east side, and extends southward, gradually descending to the lower level of the valley.

Along the Little Sioux.- The benches along the Little Sioux are not prominent within the county, and appear chiefly on the east side.

In all these cases the hills rise above these benches quite abruptly on the west side, often showing cat-steps, while on the east side the rise is more gradual, and the hills are less rugged.

These benches have sometimes been mistaken for riverterraces, * but they are evidently a remnant of an old drift plain, their stratigraphic structure being the same as that of all the uplands, as is shown in well-sections and exposures. In sections they show Missouri limestone, Nebraskan drift, Aftonian sand and gravel, Kansan drift, Loveland joint clay, post-Kansan loess, and a yellow loess which sometimes shows an imperfect division

\footnotetext{
*They were specifically referred to as "high terraces of silt" by J. E. Todd, Bulletin U. S. Geol. Sur., No. 158,1899 , p. 140. St. John also describes them as terraces, in White's Report on the Geol. Sur. of Iowa, Vol. II, 1870, pp. 178-179, and $185-186$.
} 
into two parts. The structure of these benches is shown in the Peckenpaugh well, and section, the Griffin well, and the various wells on, benches which are discussed in connection with the Aftonian.

LIST OF ELEVATIONS.

Taken from Gannett's Dictionary of Altitudes.

Harrison CoUnty.

LOCALITY

AUTHORITY

ELEVATION

Dunlap

C. \& N. W. R. R $.1,097$

Logan

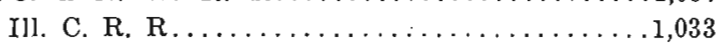

Missouri Valley

C. \& N.W. R. R

1,006

Modale

C. \& N. W. R. R

1,016

Mondamin

C. \& N. W. R. R.

1,025

Persia

C., M. \& St. P. R. R.

1,167

River Sioux

C. \& N.W. R. R.

1,042

Rode

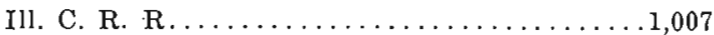

Woodbine

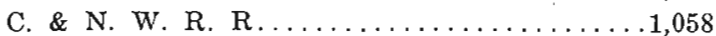

Woodbine

Ill. C. R. R.

1,069

Missouri river opposite California Junction, low water, 986, high water, 1,007.

\section{Monona County.}

LOCALITY

AUTHORITY

ELEVATION

Blencoe

C. \& N. W. R. R

$.1,043$

Grant Center

C., M. \& St. P. R. R

$.1,070$

Kennebec

III. C. R. R

Mapleton

C. \& N.W. R. R

..1,061

Mapleton

C., M. \& St. P. R. R

(?) 1,138

Onawa

C. \& N. W. R. R.

(?) 1,263

Rodney

C., M. \& St. P. R. R

1,051

Ticonic

$\ldots \ldots \ldots . \ldots \ldots 8$

Ute

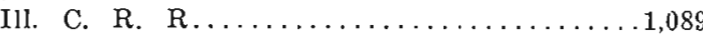

Whiting

C., M. \& St. P. R. R

1,205

Sloan, just nortl of the Monona county line, on the Chicago and Northwestern railroad, has an elevation of 1,076 feet. Smithland, on the Illinois Central railroad, also north of Monona county, has an elevation of 1,080 feet.

There is a manifest error in the Mapleton elevations, as the difference is too great, though the Chicago and Northwestern railroad is really lower than the Chicago, Milwaukee and St. Paul.

With the exception of those at Persia and Ute these elevations are but little above the bottom lands. At Missouri Valley the hills rise fully 225 feet above the valley; the summit of Murray Hil], four miles northeast of River Sioux, in section 8, township 81 
north, range 44 west, is more than 300 feet above the valley, and the hills at Turin rise from ninety to more than 200 feet above the lowlands.

\section{Drainage}

The drainage of the counties under discussion is similar to that of all that part of the state bordering on the Missouri river. The great stream furnishes the outlet to all the surface waters of both counties. As has been noted its alluvial plain is so flat that drainage is very unsatisfactory, the difficulty being increased by the natural levees which border not only the Missouri, but those tributaries which meander across its valley.

This presents a serious problem not only in connection with the great artificial drainage system now being developed, but also in relation to sanitary drainage in the valley towns. Missouri Valley and Onawa have both struggled with this problem, and other similar towns are interested, but no satisfactory solution has yet been found and put into practice.

In a manner characteristic of streams with broad, low bottomlands, the Missouri and its eastern tributaries follow very tortuous courses. It is a little more than fifty miles in a direct line from the northwest corner of Monona county to the southwest corner of Harrison county, but the present course of the Missouri river between these points is more than eighty miles long, and its length was formerly still greater, for the Lewis and Clark survey shows that part bordering Harrison and Monona counties to have been at least forty miles longer than at the present time.* Similarly sixty miles of the Boyer river are crowded into the twenty-eight miles of valley lying within Harrison county. +

The Boyer, Willow, Soldier, Maple and Little Sioux rivers have recently had their courses shortened by artificial cut-offs-the more important of which are shown on the maps-for the purpose of increasing the fall and thus the rate of run-off. It is thus expected more rapidly to release the floods which are discharged by these tributaries upon the flat bottom-lands from the interior, and from the adjacent bluffs.

* See maps of Harrison and Monona counties.

tSmith's History of Harrison County, 1888, p. 21. 
The Missouri river has naturally shortened its course, and increased its velocity, as already noted, and those who have watched the floods in the great valley for many years declare that the danger from floods of the Missouri has been thereby materially diminished.

Both the Missouri and its tributaries lave so frequently changed their courses that numerous ox-bow or cut-off lakes have been formed. The largest of these in Harrison county are the following: Noble lake, lying partly in Pottawattanie county; Horseshoe lake, Round lake and Sol Smith lake. The last of these probably formed a part of the Little Sioux, and is the finest and deepest of these lakes, and-the only larger lake in this territory lying close to the bluffs.

$\Lambda$ shallow lake, now reduced to little more than a swamp, known as McWilliams lake, lies in section 27, township 81 north, range 44 west. It drains into the Soldier.

The principal lakes of Monona county are Gard lake, Blue lake, Badger lake, and East Skunk lake. A portion of Holman lake, now on the west side of the Missouri, also falls within this county.

Blue lake is the largest of these lakes, but all of them are being diminished more or less by the recent drainage operations, and by the cultivation of surrounding lands. On the Lewis and Clark map both Blue lake and Badger lake are represented as a part of the Missouri channe]. These lakes have therefore been formed since 1804.

The principal streams of Harrison county which discharge their waters directly upon the great Missouri bottom are Mosquito creek, Pigeon creek, Boyer river, Willow river, Allen creek. Steer creek, Soldier river, and the Little Sioux river.

Mosquito creek is a small stream which crosses Washington township from north to south, and enters the Missouri plain in Pottawattamie county. Its valley within the county varies from less than half a mile to nearly a mile in width, and passes through a rolling loess-Kansan region. The upper course of Keg creek also crosses the eastern part of this township.

Pigeon creek is similar to Mosquito creek, but is somewhat smaller. It also enters the Missouri bottoms in Pottawattamie 
county, and receives as its chief tributary Potato creek, which is the smallest of these creeks. These creeks cross Union and Washington townships in a somewhat southwesterly direction, and their valleys divide the great loess-Kansan uplands of the southern tier of townships into four distinct blocks, of which the westernmost is the largest and most rugged, containing the Missouri bluffs. Its northern part in La Grange township drains to the north and west and is also very rough. The remainder of the area is typical rolling loess-Kansan.

Perhaps the finest view of this type of topography in this part of the state is that which may be obtained by looking east from Beebeetown, where the swells follow one another for miles in endless series.

The Boyer is one of the largest streams within the county, and also enters the Missouri in Pottawattamie county. Its source is: near the Wisconsin divide, and it drains a large area the waters of which give rise to disastrous floods in the lower part of the valley.

The valley of the Boyer cuts the uplands for a distance of about twenty-six miles from northeast to southwest, and varies from one to two miles in width. At two points only does it become narrower, and those are where the bench opposite Willets Siding encroaches upon it and reduces it to less than one-half mile, and at Logan where it is similarly narrowed to less than a quarter of a mile. This is one of the most important valleys of the region, and contains the principal towns of the county.

Most of the tributaries of the Boyer within the county are creeks which drain the uplands on either side. The largest of these is Willow river (a river by courtesy only) which did not enter the Boyer until it had traversed several miles of the Missouri bottoms and passed into Pottawattamie county. Throughout the lower part of its course it has since been deflected, how- ever, into the Willow creek ditch, and the Boyer has been connected with it by a cut-off in the southern part of St. Johns township. That part of the Willow valley which cuts the uplands is similar to the valley of the Boyer in direction and general character, but is narrower, varying from one-half to a mile in width. Allen and Steer creeks drain the rugged uplands of Taylor, 
Magnolia, Raglan and Allen townships, and cut them by their deep, narrow valleys. Allen creek is now carried across the bottoms by the Allen creek ditch, which passes into Pottawattamie county. Steer creek is a tributary of the Soldier.

The Soldier river is scarcely more than a creek, and the greater part of its course lies in the alluvial plain of the Missouri, its natural outlet being in Cincinnati township. It is proposed, however, to make a cut-off from section 7 to section 16 in Morgan township, thus eliminating the greater part of the stream within the county.

That part of the Soldier valley which cuts the uplands is also similar to that of the Boyer in direction and general character, and iike all the larger stream valleys of this part of the state, provides a railway outlet through the uplands. It averages about a mile in widtll, but it is much narrowed both above and below Pisgah by benches, which project from both sides.

The Little Sioux river crosses the northwest corner of the county, and empties into the Missouri just west of River Sioux. Its course within this county lies wholly in the alluvial plain of the Missouri.

The principal streams of Monona county are: the Soldier, Maple, Little Sioux and West Fork of the Little Sioux rivers.

The valley of the Soldier continues the same as at Pisgah as far as Ute, being narrowed by numerous benches on both sides of the stream. At Ute the valley divides, and that portion following the main stream becomes very much narrower.

Like all the preceding streams, the Maple river follows a soutliwesterly course, cutting through the uplands, and its valley is essentially like those of the Boyer and the Soldier. It varies flom one to two miles in width, and is frequently narrowed by benches which make of this part of the county the most fertile region in our territory. The Maple emptied into the Little Sioux in section 28, Belvidere township, but a cut-off now eonnects the streams two miles farther north, in section 16 .

The Maple also has its source on the Wisconsin divide, and drains a large area of rolling loess-Kansan. Its floods usually reach the great valley sooner than those of the larger Little 
Sioux, and the result is that frequently in the earlier floodstages the waters of the Maple run to the north, banking the waters of the Little Sioux, and causing higher water in the latter.

The Little Sioux river is the largest tributary of the Missouri in this section, and in this county the greater part of its course lies in the Missouri bottoms, chiefly along the low eastern part, close to the bluffs.

It cuts the uplands in the nortlern part of the county, its valley having the usual southwesterly direction, and averaging nearly three miles in width within the county.

The West Fork lies wholly in the Missouri plain, and joins the main stream northeast of Onawa.

The Little Sionx and the West Fork, reinforced by the Maple, cause the largest amount of annoyance and damage by floods.

The overflow area affected by this system reaches a total of 88,000 acres in Monona county and 8,000 acres in Harrison county, besides 47,000 acres along the West Fork in Woodbury county.* The width of the overflow area varies from two to more than eight miles.

Thronghout both Harrison and Monona counties the bluffs bordering the Missouri valley are higher than the region to the east, and the result is that the smaller tributary streams draining the areas lying immediately east of the crest of the bluffs flow towards the east,-away from the Missouri valley! The most conspicuous illustrations in Harrison county are found in the western part of Jackson and the eastern part of Little Sioux townships, and in the bluffs southwest of Magnolia. Those in Monona county are in the region north of Grant Center, and in the western part of Sioux and the northwestern part of Spring Valley townships.

Interesting readjustments have evidently taken place in the gradients of the streams in this part of the state.

At varions points at the base of the Missonri bluffs there are bordering banks of alluvial deposits, and most of the larger tributaries also show them. They ordinarily rise to about fifteen or twenty feet above the alluvial plain, and frequently contain molluscan shells. They are described more fully under Alluvium.

\footnotetext{
*This information was furnished by Mr. Mstchell Vincent of Onawa.
} 
These banks suggest that the streams occupied a higher level, or were subject to vastly greater floods.

That there have been changes in the level of the streams is suggested perhaps most forcibly by the smaller tributary streams. The channels of nearly all the permanent and temporary streamlets in this region are very deep and narrow, sometimes, as in section 7, township 79 north, range 43 west, southwest of Magnolia, reaching a depth of fully forty feet, while the width in many places is less than the depth, suggesting that there has been a recent rapid degradation of the stream-bed. This is further shown by the not infrequent hanging valleys of their still smaller tributaries, as along Beaver creek in Jordan township and Woodward's glen in Grant township in Monona county, and in the Magnolia locality already cited.

These narrow gulches frequently give striking evidence of these fluctuations in level. That formed by Beaver creek in Jordan township, Monona county, is especially interesting, and will serve as a type. (See plate XXXII, figure 1.) Here the creek has cut to a depth of fifteen to eighteen feet through a heavy alluvial deposit which partly filled a wider and deeper gully, the banks of which are still visible rising several feet above the newer alluvial terrace. Evidently Beaver creek had first cut a deeper and wider gully; this was then largely filled with alluvium on account of some obstruction in the lower course of the stream; and when the obstruction disappeared, or was overcome, the stream again rapidly cut into the newer alluvial deposit. That this is not merely local is shown by the fact that nearly all the smaller streams of these counties, and especially those which pass out directly into the great valley, show the same deep narrow gullies cut into recent alluvium, though not all show ods there was general slumping of the loess along the Missouri the second, or older terraces. This suggests that some general in the Missouri and its tributaries may have provided such obobstruction blocked these streams at their outlets. Great floods structions, and it is possible that during exceptionally wet peribluffs, and the consequent blocking of the smaller streams. However, no very satisfactory evidences of the latter were found 
in the field at the points of debouchure of the small valleys, and moreover such obstructions would bring about much more unequal results.

Whatever may be the cause, the fact remains that the smaller streams have quite generally cut deep and narrow gullies in the alluvium which had been deposited during the earlier process of aggrading. The walls of these gullies are usually quite vertical, and in their lower parts especially they display alluvium which is almost as tough and tenacious as Nebraskan drift. In some cases the streamlets have cut through to sand, gravel or bowlders, which may be Aftonian or Kansan, and these materials are strewn along their beds. Some of the more striking illustrations of this kind are furnished by Woodward's glen, in Grant township, and Rock creek south of Ute, and the creek east of Mapleton, in Monona county, and portions of Allen and Harris Grove creek in Harrison county. In all these cases the streams are now nearer their base level than they were when the former aggrading commenced.

It should be noted that there is no connection between the nar. row alluvial terraces of the creeks, and the larger benches along the rivers, which have already been discussed. The latter are older, and are in no sense terraces; as has already been explained on page 291.

In some cases the creeks cut their deep channels across the benches, as in Dunlap, Woodbine, opposite Logan, at Mapleton, etc.

\section{STRATIGRAPHY}

The only exposures of country rock known in the territory under discussion are those which are found in the valley of the Boyer river in Harrison county. They show Carboniferous limestone of the Missouri stage.

The greater part of these counties is covered with great beds of alluvium or drift and loess, and it is impossible to determine the character of the underlying rock, especially since but few deep wells have been sunk, and the records of most of these are imperfect or lost.

The Cretaceous is represented as extending into Harrison and Monona counties in the geological map of Iowa, published by 
Calvin, ${ }^{*}$ but the author clearly explains, on p. 199, that the Cretaceous was extensively eroded, and that on the map "the Cretaceous is indicated over the entire area upon which it was originally spread, the thick mantle of drift covering that part of Iowa making it now impossible to outline the individual remnants."

Keyes specifically reported the Cretaceous from Harrison county, $\uparrow$ but the writer has been unable to find any evidence of it whatever, and the report was probably based on the approximations of the maps.

It is interesting also to note that Udden, writing of Pottawattamie county $\ddagger$ which lies immediately south of Harrison, stated that "there seems to be no doubt that Cretaceous beds are absent from the greater part of the area comprising the western twothirds of the county." This is the portion of Pottawattamie county which is contiguous to Harrison.

No rocks are exposed in Monona county, nor could any definite information be obtained concerning the deeply buried rock strata.

Bain, in his report on Wondbury county, $\$$ represents the Cretaceous as extending to (and evidently passing over into) Monona county, the Dakota on the Missouri bottoms and "unresolved Cretaceous" in the uplands.

No evidence was found in the field, however, which would warrant the inclusion of the Cretaceous in a Monona county section, though it is not improbable that it does occur in the upland area north of Grant Center.

So far as could be determined there is a great hiatus in Harrison and Monona counties representing all that part of the geological column normally occurring between the Carboniferous and the Pleistocene. The latter is very well developed,and presents several features of unusual interest.

The following table represents a section of the formations definitely known from the counties under discussion:

* Iowa Geol. Survey, Vol. XVII. 1907, plate I. Similar maps had prevlously been published in Vols. I, II, III, VII, VIII, $X$ and XIV.

†Iowa Geol. Sur., Vol. II, $18^{9} 4$, p. 436.

:Geology of Pottawattanie County, Iowa Geol. Sur., Vol. XI, 1901, p. 239.

slowa Geol. Sur., Vol. V, 1895, map. 
SYNOPTICAL TABLE.

\begin{tabular}{|c|c|c|c|}
\hline GROTP & SYSTEM & SERIES & $\begin{array}{c}\text { FORMATIONS, SOME HAVING THE } \\
\text { RANK OF STAGES }\end{array}$ \\
\hline \multirow[t]{2}{*}{ Cenozoic } & \multirow[t]{3}{*}{ Quaternary } & Recent & $\begin{array}{l}\text { Alluvium } \\
\text { Post-Wisconsin loess } \\
\text { Sand-dunes }\end{array}$ \\
\hline & & Pleistocene & $\begin{array}{l}\text { Post-Iowan loess } \\
\text { Post-Kansan loess } \\
\text { Loveland joint clay } \\
\text { Kansan drift } \\
\text { Aftonian sands and gravels } \\
\text { Nebraskan drift }\end{array}$ \\
\hline Paleozoic & & Pennsylvanian & Missouri \\
\hline
\end{tabular}

No complete section was found in this territory, the nearest approach to it being the Peckenpaugh section opposite Logan (See plate XXX, figure 1), which lacks four members of the Pleistocene series. A large series of uniformly consistent sections, however, permitted a satisfactory determination of the stratigraphy. These sections are discussed in connection with the various formations represented.

\section{CARBONIFEROUS SYSTEM \\ Pennsylvanian Series MISSOURI STAGE.}

The only known country rock of this territory belongs to the Missouri stage or the Upper Coal Measures and its presence has been satisfactorily determined at only a few points in Harrison county. The best of these exposures is that which appears opposite Logan in and near the old quarry near the dam, now the property of Mr. Frank Peckenpaugh.

This is the exposure reported by St. John* whose report was later practically reproduced by Keyes. $\dagger$

The quarry has not been operated for some years, and slumping has somewhat obscured the sections, but a small exposure of gray limestone, about four feet in thickness, is discernible in the old quarry, and portions of the ledge on the east side were seen rising to a height of about twelve feet above the water in the river below the dam, which was then probably three or four feet

-White's Rep. Iowa Geol. Sur., 1870, Vol. II, p. 180.

Howa Geol. Surv., Vol. II, 1894, pp. 436-437. 
above low water mark. The limestone was also reached in the Peckenpaugh well and in the sand-pit, both of which are described under the Aftonian. These several sections indicate that the rock rises to a height of from sixteen to eighteen feet above low water in the Boyer below the dam, and forms a part of the base of the great Logan bench.

The following fossils were collected in rock which had been taken from the quarry some years ago, and is now piled up on the west shore of the Boyer. They were identified by Professor Calvin.

FOSSILS FROM THE MISSOURI STAGE AT LOGAN, IOWA.

PROTOZOA

Fusulina cylindrica of American authors, probably $F$. secalica Say. Not common.

COELENTERATA

Campophyllum torquium Owen. One specimen.

ECHINODERMATA

*Numerous unidentified stem segments of crinoids.

MOLLUSCOIDEA

Meekella striatocostata Cox. Three specimens.

Productus nebraskcnsis Owen. Four specimens.

* Productus costatus Sowerby. Twenty-six specimens.

Productus cora d'Orbigny. Two specimens.

Productus punctatus Martin. Seven specimens.

* Productus longispinus Sowerby. Eight specimens.

* Spirifer cameratus Morton. Twenty-two specimens.

* Spiriferina kentuckensis Sh. Two specimens.

* Seminula subtilita Hall. Forty specimens.

ARTFBOPODA

Phillipsia major Shumard. One pygidium.

The other exposures in this portion of Harrison county which were reported by St. John are still more obscure, as no attempt to work the quarries has been made for many years. They are located respectively in section 24 , township 79 north, range 43 west, and in the southeast quarter of section 28 , township 80 north, range 42 west.

No other ledges lying near the surface are known, but $\mathrm{Mr}$. Wattles reports that when borings were made for the bridge of the Chicago and Northwestern railroad across the Missouri opposite Blair, Nebraska, a hard gray limestone (evidently Missouri) was reached at a depth of forty-five feet below low water

*The species marked with an asterisk were reported in 1870 from the same exposure by St. John in White's Report, Vol. II, p. 180. 
on the east side and fifty feet on the west side of the river. The four Chicago and Northwestern railway wells at Missouri Valley were sunk to a depth of ninety feet to a bed of similar rock, and the city well reached the same depth. It is evident that in this part of Harrison county the entire Missouri bottoms are underlain with Missouri limestone. Mr. Theodore Warren, welldigger at Woodbine, reports that on the flat along the Chicago and Northwestern railway in Woodbine he finds limestone at a depth of twenty-eight to thirty feet.

COAL.

Efforts to find coal suitable for mining have been of no av́ail. Such efforts were made years ago at Missouri Valley and elsewhere, and rumors of coal or possibilities of coal within Harrison county liave been extant. St. John stated* that coal may be found at greater depths by boring, and Keyest made indefinite references to possibilities of its occurrence in the county, and included Harrison county in the report on Coal Deposits in lowa. In the more recent report of Hindst Harrison county is omitted entirely from the list of coal-bearing counties of the state.

The only definite record which was obtained in the course of the work was given by Mr. J. C. Prather, a well-digger of Missouri Valley, who reports the following well-section made on the east slope at Missouri Valley, at the home of B. Cox. This is some distance above the Boyer bottoms. In substance Mr. Prather's report is as follows:

B. Cox Well-Section.

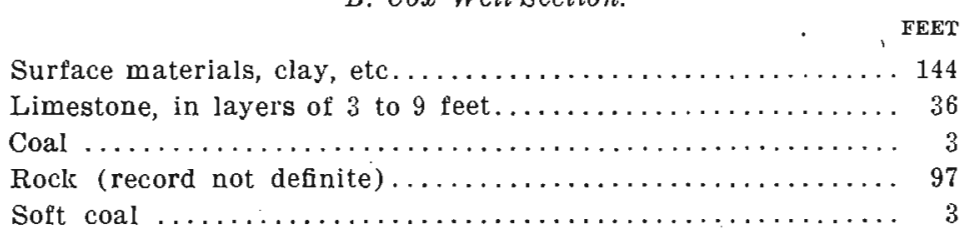

Shale appeared above and below the lower coal seam, but not with the upper.

*P. 181, I. c.

tP. 436,1 . c.

†Ia. Geol. Sur., Vol. XIX, 1909. 


\section{QUATERNARY SYSTEM}

\section{Pleistocene Series}

The Quaternary covers Harrison and Monona counties with a great mantle of drift, sand, gravel, loess and alluvium, and practically determines all the surface features of these counties. Several members of the system as known in Iowa are not present in this territory, as would be expected from its geographical position, but those which constitute the known series are consistently arranged and some of them are of unusual interest.

So far as is definitely known the Quaternary here rests directly upon the Missouri limestone, and a general section shows the following members:

7. A yellow loess, light in both color and texture, probably postWisconsin, found chiefly on the bluffs bordering the Missouri valley and the valleys of the larger tributaries. Usually blends more or less with (6).

6. A yellow, rather heavy loess, probably post-Iowan, blending with (7), but sharply separated from (5).

5. A bluish gray, compact, post-Kansan ioess.

4. The Loveland, a heavy joint clay, usually reddish, evidently closely associated with the close of the Kansan, reaching a thickness of at least forty feet.

3. The Kansan drift, very variable in thickness.

2. The Aftonian gravel, sand and silt, up to forty feet in thicliness.

1. The Nebraskan drift (pre-Kansan), which is not fully revealed in sections, being largely buried under other deposits.

The aggregate thickness of (5), (6) and (7) sometimes reaches a total of ninety feet in this territory, but on the opposite side of the Missouri, in Nebraska, it seldom reaches thirty-five feet. The relative thickness of the three loess members is very variable.

The complete section is not shown at any one point, but the members which are present are always arranged in the order indicated, excepting where there has been a manifest disturbance due to the passing of the Kansan ice over the Aftonian and $\mathrm{Ne}$ braskan beds. The detailed description of the several members follows.

NEBRASKAN STAGE.

Throughout the western and southwestern parts of Iowa and southeastern Nebraska there are exposures of a dark blue-black drift, which, as far as could be ascertained, rests directly upon 


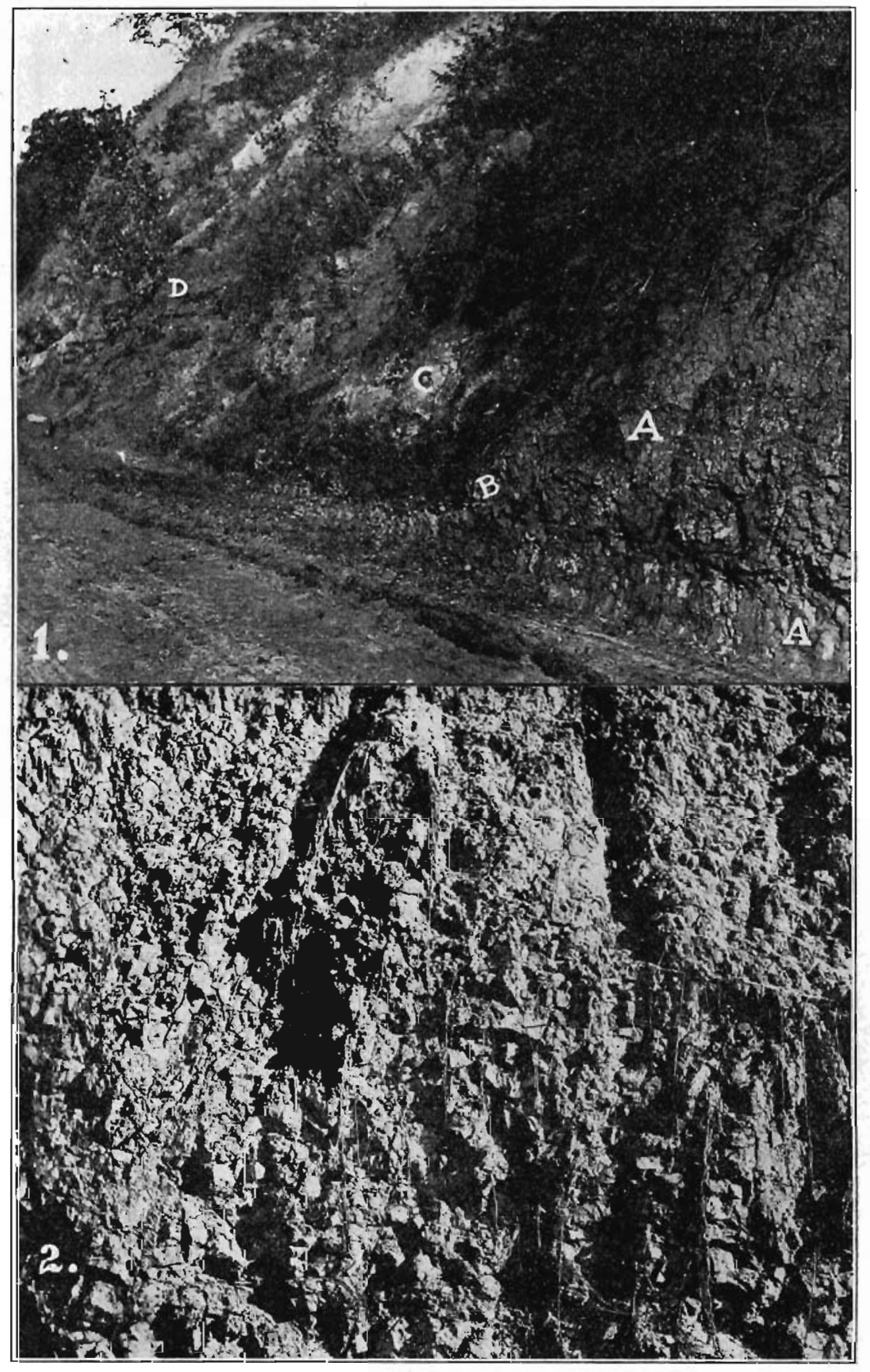

Tlate XXIV.-County-line exposure. (1) Looking north. AA. Nebriskan drift. B. Upper line of Nebraskan following road to left, rising abruptly to right. C. Aftonian sand and gravel. D. Fossiliferous Aftonian sand and silt ( $p .338$ ). (2) Nearer view of A showing Nebraskan drift (p. 307). 
$P:[306]$

(V01.20) 
the older rocks of the region. It consists chiefly of a dark blueblack joint elay, sometimes more or less ferruginous, which when dry is hard and brittle, and breaks up into very small angular blocks (resembling lumps of ordinary starch, as has been suggested) as shown in plate XXIV, figure 2. It is almost impervious to water, and when wet is very tough, tenacious, "rubberlike," and so difficult to work that it is the abomination of welldiggers and road-workers, being the most despised of all "gumbos."

Scattered through this joint clay are relatively few, usually dark-colored pebbles and small bowlders (larger bowlders are very rare) which frequently show sharp angles and fractures, or distinctly planed striated faces, demonstrating that this is a true drift.

In some respects this drift resembles some of the dark Carboniferous shales, and it has been referred to the Carboniferous. Bain called attention to this as early as 1897, , stating that "its blackness *** leads one on first view to expect a Carboniferous shale." It was identified as Carboniferous shale by Barbour, who makes repeated referencest' of the dark formation underlying the drift above Florence, Nebraska, to the Carboniferous. The formation is Nebraskan drift.

However, it must not be assumed that all dark formations underlying the Aftonian gravels are Nebraskan drift. Thus Leonard's reference $\ddagger$ to Carboniferous shale below what is clearly Aftonian in the section north of Eldon, Iowa, is correct, as are most of the similar references for that county. The possible exception is the Cass township section, page 474, where in some places along Avery creek Nebraskan drift lies just below the Aftonian gravels.

In the earlier reports the Nebraskan, Aftonian and Kansan were simply collectively included in the drift.

In the Geology of Pottawattamie county§ Udden expresses doubt that there is here more than one drift sheet, but on page

* Iowa Geol. Sur., Vol. VIII, p. 287

tNebraska Geol. Survey, Vol. II, 1906 , pp. 325 and 333 ; Science, n. s., Vol. XXV, 1907, p. 110: Putnam's Monthly, Jan., 1907, p. 502 . Gilder also uses one of these references in the Am. Anthropologist, Vol. 9, 1907, p. 703.

Towa Geol. Sur., Vol, XII. 1902, n. 474, etc.

§Iowa Geol. Sur., Vol. XI, 1901, p. 252. 
254 he states that the dark blue bowlder clay is probably identical with the so-called pre-Kansan drift.

This drift has usually received the non-committal names of pre-Kansan or sub-Aftonian, but it has also been reported under the names Albertan and Jerseyan. The Albertan is probably not glacial* and the formation in Iowa and Nebraska, which has been known to students of Iowa geology for some years, cannot be correlated with it, or with the uncertain Jerseyan. For that reason it was recently named the Nebraskan, $\uparrow$ and typical sections were pointed out near Omaha, Nebraska, and Council Bluffs, Iowa.

The finest known exposures of Nebraskan drift are displayed along the foot of the bluffs between Council Bluffs and Crescent, in Pottawattamie county, which borders Harrison county on the south. They may be traced here at intervals for several miles, the finest sections appearing about four miles north of Council Bluffs, and this older drift is exposed at longer intervals within Pottawattamie county almost to the Harrison county line.

Its position here as elsewhere is uniformly below the Aftonian, and it is exposed along the bluffs north of Council Bluffs to a depth of fully sixteen feet. Its total depth has not been ascertained.

In Harrison and Monona counties the Nebraskan drift is less prominent, but it is sufficiently well developed to fix its stratigraphic position, and to wirrant the conclusion that it underlies much of the Kansan covered area. In color, texture, composition and position it is typical, and is undoubtedly a part of the formation which is so well displayed near Council Bluffs and Omaha. - Its presence was first noticed by St. John, for the blue clays mentioned in the report on Harrison county (1. c. page 177) and on Monona county (1. c. page 184) are undoubtedly Nebraskan.

The finest exposure observed in Harrison county is that in the County line section. Here a mass sixty-five feet in length and reaching a maximum leight of ten feet above the road is exposed by a road-cut, and lies unconformably under a stratum of Aftonian gravel, its upper surface strongly oxidized. (See plate

*See Chamberlain and Salisbury's College Geology, 1909, p. 875.

tScience, n. s., Vol. XXXI, p. 75, Jan. 14, 1910. The name also appears in the Bulletin of the Geological Soc. of America, Vol. XX, in the part dated Deaember, 1909 , but this was distributed after the publication in Science. 
XXXI, figure 1.) The Murray hill exposure shows fragmentary masses of Nebraskan drift which, together with a thin stratum of Aftonian, had evidently been plowed by the later Kansan ice. Mr. Peyton reports a "dark blue clay" (probably Nebraskan) under the sand in his pit south of Pisgah. These sections are discussed more fully in connection with the Aftonian. An exposure in a creek' gully in Snyder's Hollow, Missouri Valley, also appears to be Nebraskan, but neither its structure nor its stratigraphic position could be studied satisfactorily.

The best exposure in Monona county was made in the Ordway. well opposite Castana. Beneath the gravel in the Elliott pit at Turin, Mr. Babcock found tough dark-blue clay, with bowlders, undoubtedly Nebraskan. In Woodward's Glen, north of Grant Center, Nebraskan is exposed under Aftonian gravel and sand along the bottom of the creek-gully for some distance, and to a depth of one to two feet. These sections are also discussed more fully under the Aftonian.

Mr. Patrick of Ute also reports that he dug a well on the ridge at Ute to a depth of between sixty and seventy feet, to a very dark and very hard clay.

In the same vicinity Mr. Perkins made a drive well and reached a hard layer on which rested fifteen feet of gravel. Welldiggers in a number of cases report the discovery of a tough darkblue clay, which may be Nebraskan.

\section{AFTONIAN INTERglaCial STAGE.}

One of the most important results of the survey of Harrison and Monona counties was the determination of large deposits of Aftonian gravel, sand and silt, and the discovery of a comparatively rich mammalian and molluscan fauna belonging to this interval.

The Aftonian had been known in Iowa for some years, and had been discussed by various writers in the Reports of the Iowa Geological Survey, the Proceedings of the Iowa Academy of Sciences, the Journal of Geology, etc., " but no fossils were known from this horizon, excepting such as had clearly been derived from older formations.

\footnotetext{
* See especially Calvin's paper on The Aftonian Gravels, Proc. Davenport Acad. of Science: Vol. X, 1905.
} 
The species constituting the fauna of the Aftonian, herein discussed, had also been known, but not from this formation. The mammalian fauna is represented in the Elephas imperator Zone, or "Loup River" horizon, of the "Upper Pliocene or Lower Pleistocene" "* by Elephas imperator, Mastodon mirificus and Equus, but it appears at its best in the Equus Zone which includes the "Sheridan formation," "Equus beds," and "Rock Creek beds." ** In no case was the reference definite, and the stratigraphic relation of the several beds remained more or less in doubt. If the mammalian fossils are a sufficient criterion, however, these beds may be definitely referred to the Aftonian interglacial stage as a result of the studies initiated in Harrison and Monona counties, and since extended to other parts of Iowa, and to Nebraska.

The molluscan fauna, consisting of numerous individuals of freshwater species and a few terrestrial forms which had evidently been washed down from adjoining land surfaces, has also been known from every interglacial period since the Kansan, and down to the present time. None, however, had been reported from the Aftonian, and the entire fauna, mammalian and molluscan, as here reported is new in its relation to that formation.

Aside from other considerations which are later herein presented, this fact alone made a careful study of the deposits desirable. The sands and gravels of Harrison and Monona counties, which are now referred to the Aftonian, had received previous brief notice. St. Johnt considered them modified drift, Bain reported "gravelly drift" from the northern part of Monona county, $\dagger \dagger$ and Beyer and Williams $\ddagger$ include them in the Logan section simply as "Pleistocene."

In nearby territory Udden included them with the drift in Pottawattamie county, $\ddagger \ddagger$ and Bain discussed "stratified drift" in Plymouth county, while Hayden ladd previously§ describerl those of Doug]as county, Nebraska, as drift which had been deposited by turbulent waters.

* Osborn, Bull. U. S. Geol. Sur., No. 361, 1909, p. 83.

* Osborn, op. cit., pp. 84-86. He classes them with the Lower Pleistocene, which he calls preglacial.

†White's Report, Ia. Geol. Sur., Vol. II, 1870, pp. 177, and 184.

t+Iowa Geol. Sur., Vol. V, 1896, p. 281 .

IIowa Geol. Sur., Vol. XVII, 1907, p. 496.

:Jowa Geol. Sur., Vol. XI, 1901, pp. 251-254.

$\$$ Final Rep. U. S. 'Geol. Sur, of Nebraska, etc., 1872, p. 9. 
Preliminary reports of the results of the present survey were published in Science, ${ }^{*}$ and in the Bulletins of the Geological Society of America. $†$.

\section{Structure and Composition.}

In structure and composition the Aftonian of this region varies: within well-defined limits. It consists of gravel, sand and fine silt, variously inter-bedded and cross-bedded, and evidently deposited by currents of different velocities. No peat-beds, such as occur in other parts of the state, have been observed.

The gravel and sand are variously disposed. Sometimes the gravel is at the very base of the deposit, as in the Peckenpaugh section; again it forms the uppermost part, as in a portion of the County line exposure; or it is intermediate between beds of sand, as in the Cox pit; or it is irregularly interbedded with sand, as: in parts of the County line exposure, Peyton pit, etc. In several sections fine sand only was exposed, but as the sections were not complete it is probable that gravel occurs in the deeper parts. Both the sands and gravels vary in coarseness and in degree of intermixing. The gravel beds commonly contain pebbles and bowlders up to four inches in diameter; and rarely very large bowlders of Sioux quartzite or granite occur. The sand and finer gravel frequently interbed and cross-bed, and the wedges and strata of sand are often sharply set off by lines of fine gravel. The wedges and strata are of all degrees of coarseness and vary in color. Beds of almost pure wlite sand occur, as in the Cox and Peyton pits; or the gravel and sand are stained with iron oxide, the stain sometimes permeating the entire wedge or stratum, or merely marking its limits with a more or less distinct line; or there is a similar black discoloration due to manganese dioxide $\left(\mathrm{MnO}_{2}\right)$ which occurs uniformly in greater or lesser quantity in all the sectious examined. Some variation in color is also due to the different materials which compose the sand and gravel. Dark

\footnotetext{
*B. Shimek, Science, new series, Vol. XXVIII, Dec. 25, 1908, p. 923; also Vol. XXXI, 1910 , p. 75.

tS. Calvin. "Present Phase of the Pleistocene Problem in Iowa," Vol. 20, 1909. pp. 133-152, and "Aftonian Mammalian Fauna." ihid. pp. 341-356.

"B. Shimek, "Aftonian Sands and Gravels in Western Iowa," ibid, pp. 399-408; "Evidences that the Fossiliferous Gravel and Sand Beds of Iowa and Nebraska are Aftonian," ibid, Vol. 21. pp. 119-140.
} 
colored pebbles and bowlders, such as occur in both the $\mathrm{Ne}$ braskan and Kansan drifts, are common, but there is a preponderance of rather light-colored materials.

The finer sands contain rather small, very soft, chalky, pure white, usually rounded calcareous nodules, and calcareous noclular plates usually two to four inches in thickness, frecquently separate the Aftonian from the Kansan. These are very prominent in the Cox pit (plate XXV, figure 1), the Weniger pit* (plate XXVII, figure 2), and the Ferdig pit (see plate XXVIII figure.2).

In the Cox pit these calcareous plates exhibited markings which seem to be glacial striations, and which may be compared with similar striations found by Calvin on ferruginous plates in like situations at Afton Junction. + It is impossible to conceive of the presence of these calcareous plates in their present position just above the Aftonian sands and gravels at the time of the passing of the Kansan ice over the territory in which they occur. They have evidently been formed since the deposition of the overlying drift from material carried upward in the Aftonian in solution and deposited against the lower surface of the drift.

The Aftonian beds were evidently frozen solid before and during the maximum stage of Kansan glaciation, as is shown by the numerous detached Aftonian "sand-bowlders" imbedded in the Jower part of the Kansan (see page 348) and still retaining their stratified and cross-bedded structure, and by the greater masses of Aftonian sand and gravel which similarly preserve their structure even where the strata have been so disturbed that they practically stand on edge. In this frozen condition the Aftonian beds were planed and striated by the Kansan ice as were other types of bed-rock, and when the Kansan till was deposited upon them it formed a reversed mold of the markings made by the glacial ice. Calcareous as well as ferruginous plates deposited against the lower surface of this till would reproduce all the grooves and furrows and all other markings which had originally been impressed on the planed surface of the frozen sand and gravel beds by the moving Kansan ice, and would thus appear as if they themselves had been glaciated.

* See also fig. 1, plate 2, in the Bull. Geol. Soc. of America. Vol. 21. 1910.

+Proc. Davenport Acad. of Science, Tol. X, 1905, p. 25 . plate II.I, fig. 6. 


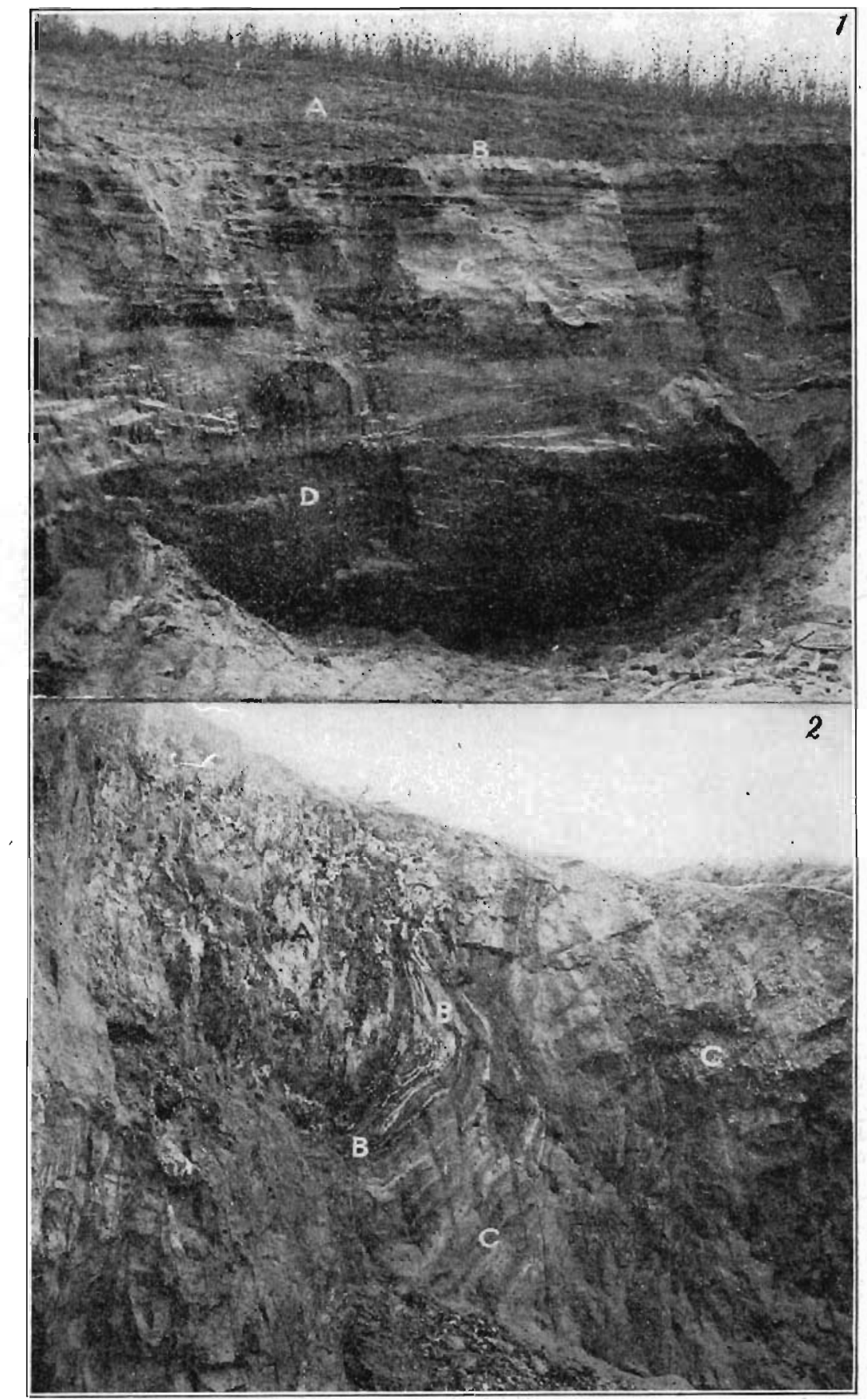

Plate XXV.-Aftonian sections. (1) Cox pit: A. Kansan drift. B. Calcareous noduIar plates. C. Aftonian sand, 21 feet. D. Aftonian. gravel, 14 feet (p. 333). (2) McGavern pit: A. Kansan. BB. Front of Kansan plow. CC. Aftonian sand, nearly
vertical (p. 351). 
$p .[314]$

(v.20) 
The silt bands and belts of the Aftonian are also variously distributed, but are most common in the uppermost or the lowermost parts of the formation and vary in thickness from a fraction of an inch to several feet. When occurring in the upper parts they consist of a heavy silt which is dull bluish gray, or less frequently yellowish or even ferruginous in color, but those in the lower part are usually made up of a finer whitish or light bluish silt which is decidedly putty-like when wet. Pellets of these silts, rolled into spherical or fusiform shapes, are frequently found in the sand and gravel. Such pellets are usually several inches in diameter; they were evidently detached and rolled by the currents which carried the coarser material, and they are usually incrusted with ferruginous sand. Sometimes similar pellets of Nebraskan drift, evidently formed in the same manner, are also found in the Aftonian sand and gravel. They are readily distinguished from the silt pellets by their darker color and by the presence of pebbles.

Occasionally more or less cylindrical masses of silt or sand penetrate the sand and gravel beds irregularly in the upper portions of the formation. These were evidently formed by silt and sand being carried down by water into cavities formed upon the decay of the roots of plants. They appear in cross-section as round spots, and some are shown in plate XXVIII, figure 1, representing the Elliott pit. Here these tubes, or rather cylinders, consisted of fine sands, silt, which is present in the uppermost part of the section, and loess which caps the ridge. In this section they vary up to about three inches in diameter.*

\section{Organic Remains.}

Organic remains are quite frequent in the Aftonian and form a feature of unusual interest. No plant remains were found, though mosses and conifers are known from the peat-beds in other parts of the state.

Animal remains, consisting of bones, teeth and tusks of mammals, and shells of mollusks, are quite abundant and widely distributed. One small vertebra of a fish was also found.

*See also Bull. Geol. Soc. of Am., Vol. 21, plate 2, figure 2. 


\section{THE MAMMALIAN FAUNA.}

The following species of mammals have been definitely identified by Professor Calvin:

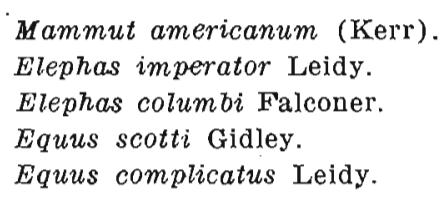

Two molars, fragments of a tusk and of cranial bones of Mammut mirificum (Leidy) were also collected in the Aftonian of Plymouth county, in the same general territory, and a tooth of Elephas primigenius Blumenbach was collected in what appears to be Aftonian at Denison, only a few miles from the Harrison county line.

In addition to these Professor Calvin recognizes bones of unidentifiable species belonging to the following genera:

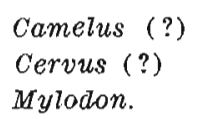
Denison deposit. There are also bones of other mammals not yet identi. fied.

The bones and teeth were mostly scattered, often fragmentary and usually freely intermingled as though the bodies of the animals had been stranded on ancient bars and, after the decay of the softer parts, their skeletons had been scattered by the same floods which moved the great mass of gravel. Occasionally, however, they were transported when at least some of the bones were still united by ligaments, for in some cases the bones and teeth of evidently the same skeleton lie in close proximity, as in the Wilkenson well, and in the Akron wel] in Plymouth county.

Professor Calvin has discussed these Aftonian mammals quite fully, ${ }^{*}$ and that part of his paper which has a direct bearing on the Aftonian of our territory is here reproduced. In the paper quoted the discussion of the teeth of horses from the Aftonian

*In the Bulletin of the Geol. Survey of America, vol. 20, pp. 341-356, plates 16-27. 
of Harrison and Monona counties is so intimately connected with that of the fine sets of upper and lower left molars and premolars of the Gladwin horse obtained from Mills county, that the latter is also here included, though the specimens are extra-limital:*

The discussion is presented in Professor Calvin's own words:

The Aftonian Horses.

In the collections under consideration horses are represented by a much larger number of bones and teeth than any of the other types of Aftonian mammals. There are bones from nearly all parts of the skeleton, but leg bones and foot bones are most common and most significant. Among the teeth there are more than twenty superior molars and premolars and about an equal number from the lower series. The Gladwin set is the only one that is complete; the other teeth show great variations in the amount of wear and in minor details, and it is quite certain that they represent a number of individuals. At least two species seem to be clearly indicated. In one the teeth are larger than those of the modern species, as is shown by the following comparisons and measurements of the upper molars of the Gladwin hor'se. Comparison is made with the measurements of the teeth of the domestic species, expressed in millimeters, as given by Gidley in the table on page 98 of volume xiv of the Bulletin of the American Museum of Natural History. Only the transverse diameters are compared, but the other dimensions show corresponding differences in size. In the case of the teeth of the Gladwin horse, to quote from Gidley, "the transverse diameters were measured across from the exterior ridge of the mesostyle to the exterior wall of the posterior lobe of the protocone, exclusive of cement." In the Gladwin horse fully half the original length of the teeth has been worn away. The antero-posterjor dimensions of the entire series of superior grinders, measured in a straight line from the sharp, anterior enamel fold of $p^{2}$ to the posterior, outer fold of $\mathrm{m}^{3}$, is 187 millimeters. The antero-posterior dimensions of the individual teeth, following the outer curve of the series, but inside of the metastyle and parastyle, are: $\mathrm{p}^{2}, 43.5$ millimeters; $p^{3}, 33$ millimeters; $p^{4}, 31$ millimeters; $\mathrm{m}^{1}, 25$ millimeters; $\mathrm{m}^{2}, 26$ millimeters, and $\mathrm{m}^{3}, 32$ millimeters. This gives a total length of the series around the outer curve, but inside the external styloid ridges, of 190.5 millimeters.

*Professor Calvin refers to the Gladwin horse as follows: "A complete set of left molars of a large horse, upper and lower, was found by Mr. E. L. Gladwin while grading a road in section 35 , Tyons township, Mills county, A considerable portion of the skeleton was present, but the bones were too soft for preservation. The Gladwin horse was found in a fine blue clay, a bed of silt, that here in places overlies the gravels but is of the same age." Loc. cit., p. 344 . 
Table showing comparative transverse Diameters of the Teeth of the Gladuin. Horse.

\begin{tabular}{l}
\hline \hline \\
\hline
\end{tabular}

There are a number of teetlı from the Cox pit at Missouri Valley, and one from Turin, which agree in dimensions with the larger teeth of the Gladwin horse, and are evidently from the same species, if transver'se diameters may be taken as a guide. These may be noted in tabular form as follows:

\begin{tabular}{|c|c|c|c|}
\hline $\begin{array}{l}\text { Catalogue } \\
\text { number }\end{array}$ & $\begin{array}{l}\text { Trans- } \\
\text { verse } \\
\text { diameter. }\end{array}$ & $\begin{array}{l}\text { Antero- } \\
\text { posterior } \\
\text { diameter. }\end{array}$ & Length. \\
\hline 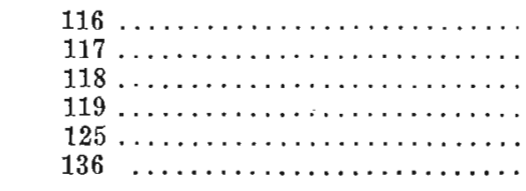 & $\begin{array}{l}33.0 \\
33.5 \\
32.0 \\
31.5 \\
31.0 \\
33.0\end{array}$ & $\begin{array}{l}33.0 \\
35.0 \\
32.0 \\
29.0 \\
30.0 \\
35.0\end{array}$ & $\begin{array}{l}95 \\
82 \\
38 \\
50 \\
62 \\
80\end{array}$ \\
\hline
\end{tabular}

An imperfect second upper premolar, with the thin, anterior edge broken away and having a transverse diameter of 29 millimeters, belongs in this group of large teeth. Nearly one-third of the crown has been worn off by use; the part remaining measures 65 millimeters in lengtl.

Among the recognized species of Pleistocene horses the teeth of the Gladwin horse and the others above noted agree best in size with Equus scotti Gidley, from the Sheridan beds, Rock Creek, Brisco county, Texas, ${ }^{*}$ though tooth number 117 is practically identical in size and other details with the superior third and fourth premolars referred by Gidley to Equus pacificus Leidy.t Comparing the Gladwin teeth with the measurements given for Equus scotti in the American Museum Bulletin, volume xiv, page 136, the close agreement becomes apparent:

* Bulletin of the American Museum of Natural History. Vol. XIV, p. 134. tOn. cit., p. 117 . 


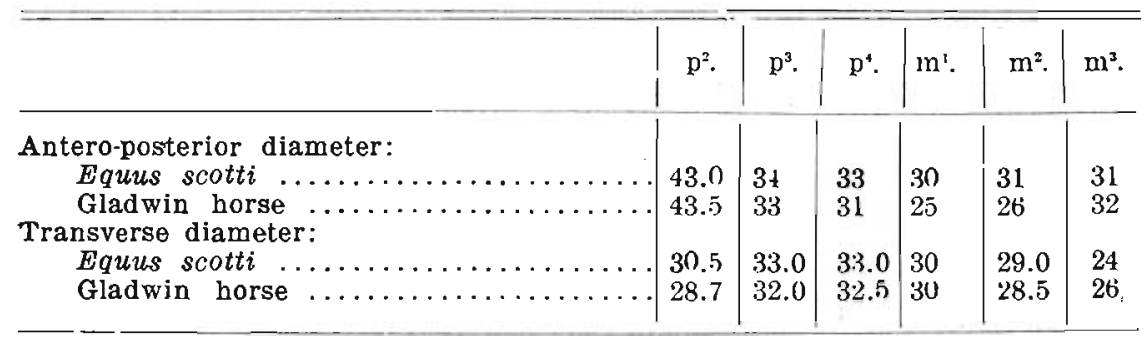

The differences that appear in making these comparisons may be accounted for on the basis (1) of individual variations and (2) of differences in the amount of wear which the teeth of the two animals has undergone. The measurements of Equus scotti given on page 136 of the work cited are those of an individual "in which all the teeth have come into full use," but presumably an animal comparatively young. The teeth of the Gladwin horse, on the other hand, have been worn down to about half their original length. The greatest discrepancy appears in the antero-posterior diameters of $\mathrm{m}^{1}$ and $\mathrm{m}^{2}$ and in the transverse diameters of $\mathrm{p}^{2}$ and $\mathrm{m}^{3}$. Applying Gidley's "Laws governing the changes of diameters of the tooth crowns," formulated on page 99 of the American Museum Bulletin already quoted, the differences are largely, if not wholly, explained. After the molar-premolar series comes into full use, according to law (1), the antero-posterior diameter of each of the intermediate teeth diminishes at first very rapidly, and then more gradually to the roots. Differences even as great as those seen in $\mathrm{m}^{2}$ and $\mathrm{m}^{2}$ are to be expected. The antero-posterior diameter of $\mathrm{m}^{3}$ in the Gladwin horse accords with law (3). The differences in transverse diameters of the first and last teeth of the series exemplifies that part of law (4) which is expressed in the clause " $p^{2}$ gradually diminishes, while $\mathrm{m}^{3}$ increases in transverse diameter as the crown wears away." In the present case the teeth are the only parts available for study, but these are in such perfect accord with the teeth of Equus scotti Gidley that there need be little hesitation in referring them to that species. Equus scotti has been recognized with doubt in collections from the Sheridan beds near Hay Springs, Nebraska,* a point farther north than southwestern Iowa and equally as far from the type locality.

The collection contains a few teeth of smaller size, agreeing in dimensions and in the enamel foldings with teeth which have been referred to Equns complicatus Leidy. A superior third molar,

*W. D. Mathew: Iist of the Pleistocene fauna from Hay Springs, Nebraska. BuIletin of the American Museum of Natural History, Vol. XVI, 1902, p. 317. 
number 128, from Missouri Valley, shows a very complicated pattern, even though considerably worn. Its dimensions are: transverse diameter, 24 millimeters; antero-posterior diameter, $2 i$ millimeters; length, 60 millimeters. An Aftonian gravel pit at Turin, Towa, has furnished an imperfect superior molar, number 122, intermediate between the first and the last of the series, but its exact position undetermined, which shows a transverse diameter of 28 millimeters and a length of 70 millimeters. The anterior fourth of the tooth has been split off, but what remains shows very complicated enamel foldings. Another tooth, number 124, of somewhat simpler pattern, but still sufficiently intricate to belong to $E$. complicatus, is from the Cox pit at Missouri Valley; it is 28 millimeters in transverse diameter, 29 millimeters anter aposteriorly, and 70 millimeters in length. Tooth number 121 is also from the Cox pit; it is 75 millimeters in length, but little worn; the enamel pattern is much simpler than in any of the other teeth so far noted. It agrees with Equus excelsus and $E$. occidentalis in the absence "of the little enamel fold near the bottom of the deep valley between the protocone and the hypocone.". It is 28.5 millimeters in transverse diameter and 30 millimeters from front to back. In size and pattern, however, this tooth is almost identical with Gidley's figure $3 \mathrm{~A}$, in the American Museum Bulletin, volume xiv, page 97 , and this figure is described as a.molar of Equus complicatus. If the teeth illustrated in figure 3 , page 97 , and in figure 7 , page 109 , of the bulletin above quoted may be referred to one species, then all the superior molars from the Aftonian gravels of soutliwestern Iowa may be arranged under two species distiuguished by differences in the size of the teeth, namely, Equus scotti Gidley and Equus complicatus Leidy.

Of the lower molar-premolars there are two well marked types which probably correspond to the two species, Equns scotti and Equus complicatus. The left mandibular series of the Gladwin horse illustrates one of these types. The teeth have very thick c(土nentum and are unusually heavy; the transverse diameters measured in millimeters, exclusive of the cementum, are: $p_{2}, 18$; $p_{s}, 19 ; p_{\jmath}, 21 ; m_{1}, 17$. The otler molars are broken and cannot be measured. The thickness of $\mathrm{p}_{4}$, including cementum, is 24 millimeters. The length of the series antero-posteriorly is 195 millimeters. Another notable feature of these teeth is the great thickness of the enamel. The same thick enamel and massive charac ter are seen in two inferior molars from the Cox pit at Missouri Valley. This specimen may without doubt be referred to the same species as the Gladwin horse. All the other inferior molar's 
in the collections belong to the other type. The transverse diameters are less, the cementum very meager, and the enamel is much thinner and more flexuous. *** The thinner teeth, with thinner and more flexuous enamel, may be looked upon as teeth belonging to a species quite distinct from the Gladwin horse and may be associated with the superior molars which have been referred to Equus complicatus.

*** One tooth shows the effects of alveolar abscesses from which the animal probably suffered seriously. Whether this disease hastened the death of the individual may not be known, but it is certain that life was cut short from some cause before the teeth were very much worn.

There are many equine bones from the Aftonian beds of Harrison and Monona counties which, while more or less fragmentary, are in a fair state of preservation. There are two humeri, right and left, each lacking the proximal articulation. These indicate an animal about the size of the average modern hor'se, the radius and ulna of the domestic species fitting perfectly with the radial articulation of the fossil humerus. There are portions of the radius among the fossil bones, four tibix, four imperfect metapodials, four first phalanges, and other portions of equine skeletons. The most perfect of the tibire is comparatively small. The animal to which it belonged was adult, but the size would indicate a rather small pony. On the other hand, the distal ends of two of the fossil tibiæ are equally as large as the corresponding part of Equus caballus, and the same is true of the distal end of a fossil radius. The sides of the broadened articular extremity of the Aftonian radius are abraded, making measurements impossib]e, but $70 \mathrm{millimeters} \mathrm{above} \mathrm{the} \mathrm{articulation} \mathrm{both} \mathrm{modern} \mathrm{and}$ fossil bones are 60 millimeters in transverse diameter and 35 millimeters in thickness. The fossil metapodials are large and strong and differ in cross-section from the same bone of the domestic species, being more nearly circular in corresponding parts of the shaft. The splint bones were evidently more rudimentary than in the modern horse. Three of the first phalanges are as large as those of the present coach horse; the largest one measures 92 millimeters in length, is 58 millimeters in transverse diameter at the proximal end, 41 millimeters broad at the narrowest part of the shaft, and 51 millimeters at the distal end. A slenderer phalanx, that of an immature individual, is 87 millimeters long and the narrow shaft is 33 millimeters wide. An examination of the equine bones from the Aftonian gravels, entirely apart from the evidence furnished by the teeth, suggests 
the possibility of at least two Aftonian species, one somewhat smaller than the average horse of today, the other fully equaling the modern horse in size.

The teeth of the Gladwin horse and the other teeth above referred to Equus scotti Gidley are all notably larger than those of Equus caballus, while the teeth referred to Equus complicatus are about the size of the teeth of the domestic horse. According to Gidley, in the article from the American Museum Bulletin, volume xiv, frequently quoted in this paper, the head and the teeth of the Pleistocene horses were proportionately larger than in the modern species. On page 139 of the bulletin Equus complicatus is described as "a species with teeth about the size of those of the ordinary draft horse and of moderately complex pattern, but with the bones of the skeleton about the size of those of the smaller varieties of the western pony." Notwithstanding the large size of the teeth in Equns scotti, it is said that "this species represents a horse about the size of the largest western pony." While in all probability the Aftonian horses represent but two species, Equus complicatus and Equus scotti, the fact should not be overlooked that some of the bones and teeth agree with those of Equus pacificus, concerning which it is stated that "the skeleton indicates a horse about the size of the ordinary draft horse, but the skull is proportionately larger." Many of the fossil bones are about the size of those of the ordinary draft horse.

Two of the equine metatarsals and two of the phalanges from Turin are decidedly larger than the corresponding bones from the modern liorse. One of these large cannon bones is complete and measures 30.5 centimeters in length, while a metatarsal of a fair sized modern horse, with which it is compared, measures but 27 centimeters. Other measurements show corresponding differences between the fossil and the domestic species. One of the teeth noted in the-paper agrees in size with $E_{\text {quns pacificus Leidy. }}$ It is larger than the teeth of Equns scotti recorded by Gidley. It may be possible that this large tooth and these large cannon bones belong to a species larger than Equus scotti; but on the other hand it is possible that individuals varied, and that some of the animals belonging to the species Equus scotti may have exceeded "the size of the largest western pony." The solution of some of these questions must await additional evidence.

\section{Other Ungulates.}

Of the ungulates associated with the Aftonian horses, one of the more significant is the camel. This is represented by a single 
first phalanx which came from the Peyton pit at Pisgah.* It is 127 millimeters long, 36 millimeters in transverse diameter at the proximal end, 31 millimeters across at the distal end, and the smallest diameter of the shaft is 20 millimeters. Other Artiodactyls are indicated by the distal ends of two metapodials, and there are two unidentified horn cores. There are two large calcanea and other undetermined bones, probably of Ungulata. $†$

\section{Proboscideans}

\section{ELEPHANTS.}

Elephas imperator:--Three elephants are indicated by the collections from the Aftonian gravel pits. A large, slightly worn molar has the massive proportions and the coarse ribs which distinguish Elephas imperator Leidy. This ponderous, clumsy tooth is from the Peyton pit at Pisgah; it is 290 millimeters (about 113/s inches) in length, 108 millimeters (41/4 inches) across the grinding surface, and 265 milimeters (103/4 inches) high, measured between two planes parallel to the grinding surface. The enamel loops, corresponding to the longitudinal ridges on the lateral faces of the tooth, vary in thickness and in the width of the intervening spaces, but on the whole they are more constant in these respects than are those of the tooth illustrated by Holmest and Lucas $\oint$ and which served to re-establish Elephas imperator as a valid species. In some parts of the Iowa specimen the ridges are fully an inch in width, the number in 10 inches ranging from 11 to 14 , according to the part of the tooth selected for measurement. Besides the large tootli from Pisgah, there is an imperfect lower jaw from the ( $\mathrm{Ox}$ pit at Missouri Valley (plate XXVI, figure 1) which belongs to this species. In both rami the inner side of the alveolus has been broken away, but the outer wall is intact and shows the broad, vertical grooves corresponding to the wide ridges on the lateral face of the tooth. These are of the same order of magnitude as the ridges of the Pisgah tooth referred to Elephas imperator. A large femur to be noted later probably belongs to this species.

Elephas primigenius and $E$. columbi.-There are other and very different elephant teeth in the Pleistocene collections of the University of Iowa in which the number of ridges in 10 inches

\footnotetext{
* Two teeth and three additional phalanges have been recelved since this paper was published.

- Hince the publication of Professor Calvin's paper a part of a Ieft ramus of Cervus (?) was received from the Cox pit. It contains the last premolar and the first and second molars.

tWilliam Henry Holmes: Flint implements and fossil remains from a sulphur spring at Afton, Indian Territory. Report of U. S. National Museum for 1901, p. 244 , plate 9 .

\$r. A. Lucas: Maryland Geological Survey, 1906. Pliocene and Pleistocene mammalia, p. 167, plate XXXVIII, fig. 2.
} 
range from 20 to 25 . There is one from the Cox pit showing 20 folds or ridges in the space mentioned, and another from the gravels at Denison showing 25. The specific relationship of these admits of little doubt. Lucas, in the work cited, page 159 , specifies 18 ridges in 10 inches as characteristic of Elephas columbi and 24 in the same space as marking the molars of $E$. primigenius. Making the necessary allowance for individual variations, the Cox Pit tooth, with its average of two folds to the inch, is referred to $E$. columbi, and the Denison tooth, with two and a half folds to the inch, represents, without doubt, the $E$. primigenius. The last agrees in almost every minute detail with a tooth of $E$. primigenius from Europe.*

\section{MASTODON : MAMMUT AMERICANUM.}

The common American mastodon is represented in the Aftonian collections by a portion of the lower jaw-the symphysis and left ramus, with the last three molars in place (plate XXVI, figure 2 ) - and by three separate molars. The jaw is from the Pisgah pit and the separate molars are from Missouri Valley. The Pisgah specimen is massive and shows the deep sockets for the mandibular tusks. The teeth from Missouri Valley are molars 4, 5 and 6 , but they are not from the same individual. The fifth molar has the crown completely worn down, and the fangs show effects of absorption; the sixth molar is perfectly developed, but practically unworn.

\section{OTHER PROBOSCIDEAN REMAINS.}

The other proboscidean fossils worthy of note include a complete left tibia (plate XXVI, figure 5) from Missouri Valley, a humerus and a femur (plate XXVI, figures 4,6), both imperfect, from Pisgah, and a cervical vertebra (figure 8) from Turin. A scapula, complete when taken from the pit at Missouri Valley, was allowed to crumble to pieces for lack of care by the finders. There are two caudal vertebræ, and a fragment of a pelvis, and, in addition, there is a section of a lower tusk of the mastodon.

The large femur mentioned above is 45 inches long, and yet it lacks all of the enlarged proximal end; it is broken at the thin, flattened part of the shaft below the great trochanter. When complete the length was certainly more than 61 inches, the reported length of the femur of $E$. imperator from Keene, Oklahoma, noted by Lucas on page 168 of the work eited above. The Warren mastodon was among the largest of its species; its

* A very fine fourth molar of Elephas columbi has since been found in Aftonian gravels in the Peckenpaugh pit at Logan. 


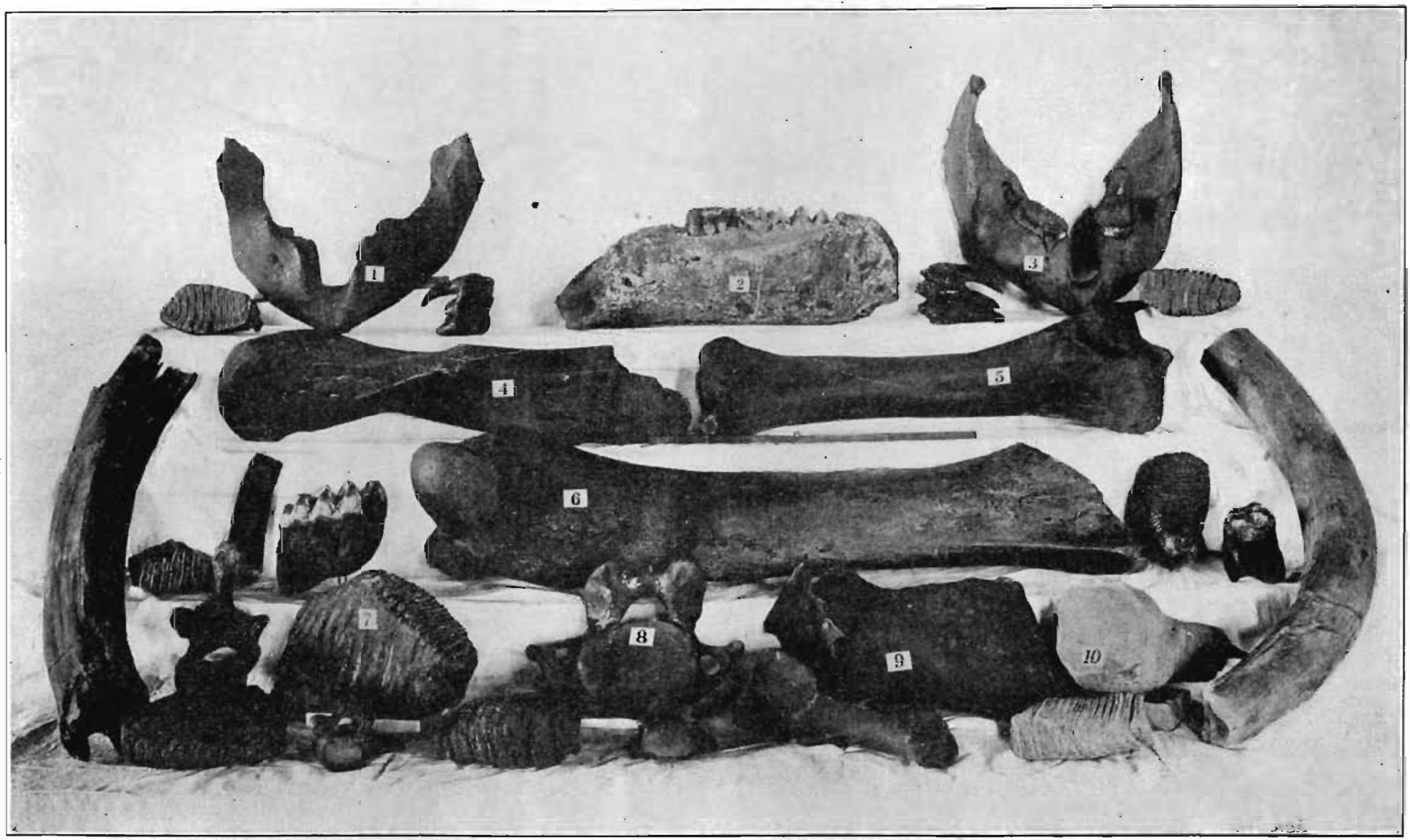

Plate XXVI.-Proboscidian remains from the Aftonian (see pp. 323, 324, 335). 
femur, complete, is said to be 45 inches in length.* The Pisgah femur belonged to an animal larger than the ordinary mastodon, larger than the modern elephant or the northern mammoth, and it is a fair inference from its great size that it belonged to the imperial mammoth, a tooth of which comes from the same gravel pit.

\section{Edentata}

MYLODON.

From the noted Cox pit at Missouri Valley there comes an imperfect terminal phalanx of Mylodon. The tip of the ungual process is broken off; otherwise it is practically complete and shows the characteristics of this part of Mylodon very clearly. The claw as a whole is proportionately much thicker, is less falcate, and tapers less rapidly toward the point than do the claws of Megalonyx. The ungual process is regularly rounded on the upper side instead of being compressed to a relatively sharp ridge. All the characteristics coincide with Owen's classical description of the distal phalanges of Mylodon. $\dagger$

\section{MEGALONYX.}

The probable presence of Megalonyx as a member of the Aftonian fauna is noted in the body of the paper; the only point concerning which there might be possible doubt is the age of the beds in which the specimen collected by Todd was found; a claw now in hand from Sioux City places the matter of an Aftonian Megalonyx beyond question, but the genus is not yet represented in the Aftonian fauna of Harrison and Monona counties.

\section{Correlation.}

The Aftonian fauna is as yet very incomplete. Additions to the list of species must wait on the further development of the sand pits and gravel beds. Besides the sloths, the forms thus far discovered and recognized are all large herbivores. $t$ An attempt

\footnotetext{
*The length of the femur of the Warren mastodon does not seem to be stated in Doctor Warren's classic memoir, but on page 107 he compares the femur of the Cambridge mastodon with that of the elephant Pizarro This bone in the Cambridge specimen measures only 36 inches in length. In the Twenty-first Annual Report of the Regents of the University of the State of New York, pages 120 and 127, there are comparative measurements; the femur of the Warren mastodon is given as 45 inches long and that of the Cohoes mastodon as $411 / 2$ inches.

†Richard Owen: Description of the skelton of an extinct gigantic sloth, Mylodon robustus Owen, pp. 94, 95, 107, 122. Leidy's work, A memoir on the extinct sloth tribe of North America, Smithsonian Contributions to Knowledge, accepted for publication December, $1853, \mathrm{p} .37$, describes the ungual phalanges of Megalonyx. The plates in both of these publications assist in making clear the differences between the claws of the two great sloths mentioned.

:An exception must be made of Ursus, discovered since the publiction of Professor Calvin's paper.
} 
to correlate the Aftonian beds with Pleistocene faunal zones which have been established in regions lying outside the glaciated area would probably, at the present time, be somewhat premature, but there are a few facts of some significance which may be noted. The deposition of the pre-Kansan drift certainly did not take place until some time after the actual beginning of the Pleistocene, and yet Elephas imperator was present in the long, mild interval which followed the pre-Kansan. Associated with the imperial mammoth were such typical members of the Equus fauna as Equus scotti and Equus complicatus. The camel and the Mylodon add other faunal elements which have some bearing on the question of correlation. Fragmentary and incomplete as is our knowledge of the Aftonian fauna, enough is known to warrant the statement that it resembles most closely the fauna of the Equus zone or "Sheridan formation" as that fauna has been listed by Matthew* and Osborne. ${ }^{*}$ The localities from which the Aftonian fossils have been collected are not very far from the type localities of the Sheridan beds in Sheridan county, Nebraska. A statement by Scott, remarkable for its insight and suggestiveness, may here be quoted. Speaking of the Sheridan stage (Equus beds), he says : $\ddagger$

"It is to a large extent, of xolian origin and in places contains great numbers of fossil bones. In South Dakota the Sheridan passes under a drift sheet, and probably it corresponds to one of the earlier interglacial stages."

If, as now seems probable, the Sheridan may be correlated with the Aftonian, it corresponds to the very earliest of the known interglacial stages.

\section{THE MOLLUSCAN FAUNA.}

The mollusks of the Aftonian of this region, though apparently insignificant when compared with their giant mammalian contemporaries, are of great interest, for not only do they throw light upon the conditions under which the Aftonian deposits were formed, but they demonstrate the remarkable stability and persistence of the species represented; for notwithstanding the invasion of Iowa by four distinct ice-sheets since the Aftonian, all the species of Aftonian mollusks thus far identified have come down to the present time without material change!

\footnotetext{
*W. D. Matthew: List of the Pleistocene fauna from Hay Springs, Nebraska. Bulletin of the American Museum of Natural History, Vol. XVI, p. 317.

tHenry Fairfield Osborne: Cenozoic Mammal Horizons of Western North America. Bulletín No. 361, U. S. Geological Survey, p. 85 .

IWilliam B. Scott: An introduction to Geology, second edition, p. 782 . New York, 1908 .
} 
In order that the similarity of the Aftonian and modern mollusks may be more fully appreciated a list is here presented showing the species which were collected by the writer in the Aftonian of Harrison and Monona counties, together with a comparison with the modern fauna from Lake Okoboji.

AQUATIC SPECHES.

Unio metanever Raf.

Unio anodontoides Lea.

* Sphaerium sulcatum (Lam.) Pr.

*Pisidium abditum Hald.

Pisidium compressum Prime.

*Amnicola

*Bythinella obtusa (Lea) St.

* Valvata tricarinata Say.

Valvata bicarinata Lea.
Ancylus rivularis Say.

Lymnaea reflexa Say.

*Lymnaea caperata Say.

${ }^{*}$ Lymnaea humilis Say.

*Physa integra Hald. (?)

* Planorbis bicarinatus Say.

*Planorbis parvus Say.

*Planorbis dilatatus Gld.

Segmentina armigera (Say) H. \& A. Adams.

TERRESTRIAL SPECTES.

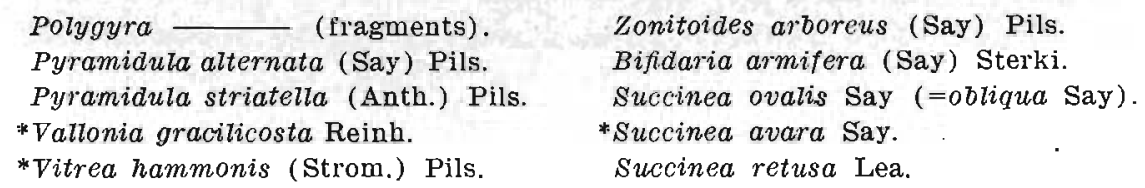

*Vitrea hammonis (Strom.) Pils.

Unlike the mammalian remains, which are usually found in gravel, the foregoing species of mollusks were collected chiefly in the finer sands of the Aftonian. A few valves of Sphaerium sulcatum and fragments of Unios are sometimes found in gravel, but this is exceptional. In number of individuals the aquatic species predominate, the land shells being represented by but few specimens which were evidently washed in from nearby land surfaces.

The species which are marked with an asterisk were also collected in Millers Bay, West Lake Okoboji, Iowa. This set of modern shells was selected for comparison because while Lake Okoboji is some distance to the north and east of our territory, the molluscan fauna of its vicinity is essentially the same, and moreover the lake is a reservoir into which shells may be washed from the surrounding land surfaces on which terrestrial species are quite common, and we have here a fair means of determining to what extent they are so transported. These shells were obtained by dredging in Millers Bay which forms a regular rounded 
indentation in the west shore of West Lake Okoboji. The dredging was done in water four to eight feet deep near the head of the bay just opposite the Iowa Lakeside Laboratory.

It will be noticed that practically all the Aftonian aquatic species were also collected in the bay. Where only the generic name is given the identification has not been completed, but the Aftonian and lake specimens are evidently identical. All the species which were not dredged from the bay are also living in Iowa today. Unio metanever (=Quadrula metanevra (Raf.) Simp.) and Unio anodontoides (= Lampsilis anodontoides (Lea) Baker) are common in the larger streams of Iowa and eastern Nebraska today; Valvata bicarinata is found in the state occasionally, more frequently in the eastern part; Ancylus rivularis is common in the Des. Moines river less than twenty miles away; and Lymnaea reflexa is common in ponds near the lake, and also along the shores of other portions of the lake. The bay also yielded several aquatic species which have not been found in the Aftonian. They are: Unio luteolus Lam. (=Lampsilis luteolus (Lam.) Bak.), an Anodonta, four additional species of Planorbis, two of Lymnaca, one of Aplexa, all living in the bay or in ponds communicating with it. The similarity of the aquatic fauna of the bay to that of the Aftonian is striking. It is a fauna belonging to the larger streams and lakes, and is unlike the terrestrial fauna with its occasional small-pond pulmonates which characterizes the loess.

It will be noticed that three of the terrestrial species occurring in the Aftonian were also dredged from the bay. Two specimens of Succinea avara and one each of Vitrea hammonis and Vallonia gracilicosta were secured in this way, together with one specimen of Vallonia parvula Sterki, a species not known from the Aftonian.

It is important to note the small number of terrestrial. shells which find their way to the bottom of the bay, especially since terrestrial species are abundant in the groves bordering the bay, and great numbers of them are carried out on the lake by freshets to be thrown ashore again. This was well illustrated during the summer of 1909, when great numbers of shells, largely 
terrestrial species, were thrown out upon the north shore of Millers Bay. The bay is bordered by native forest on the west and south shores, and in these groves dwell mole than twentyfive species of terrestrial mollusks, some of them in large numbers. The dead shells of these species, often perfectly fresh, are washed into the bay, and are driven to the north shore by the prevailing southerly or southwesterly winds, where they are massed literally in thousands on the flat beach, together with aquatic species from the bay itself. No forest suitable as a habitat for these species occurs on the slopes adjacent to the north shore of the bay, and the only possible source of these shells is on the opposite, or southerly, timbered part of the shore. Yet notwithstanding the great number and variety of forms which were so carried across the bay, ${ }^{*}$ but few find their way to the bottom as was shown by the result of the dredging. In the light of this fact it seems fair to conclude that the relatively larger number of terrestrial forms in the Aftonian points to a rich terrestrial fama and large land areas bordering the ancient Aftonian streams. $\dagger^{+}$

\section{Significance of the Aftonlan Fauna.}

The importance of the Aftonian mammalian fauna in determining the age of certain beds containing remains of large mammals has already been noted.

Certain other considerations make the entire fauna, mammalian and molluscan, worthy of further note. The presence of this fauna makes possible a more accurate approximation to the correct determination of the climatic and surface conditions which prevailed during the Aftonian.

Some light is thrown upon these conditions by the presence of the mammalian fauna made up chiefly of large herbivorous animals which evidently required large quantities of plant food and which could therefore probably live only in a climate supporting

*The drifted material from the north shore of the bay contained the following aquatic forms: one species of Pisidium, one Amnicola, one Valvata, five Planorbis, one Segmentina, four Lymnaea and one Aplexa. Mingled with them in great numbers were the following terrestrial forms: one species of Carychium, one Euconulus, two Zonitoides, one Vitrea, one Pyramidula, one Helicodiscus, one Punctum, one Strobilops, five Bifiaria, three Vertigo, one Pupoides and one Cochlicopa. Hundreds of specimens of some of these species were collected.

In making the comparison with Millers Bay conditions it should be, understood, however, that strong currents such as evidently prevailed in Aftonian streams would cause a larger number of shells to sink. 
abundant plant life. While all these species of mammals are extinct and it is not safe to draw conclusions concerning the habits of animals from mere relationship, it seems reasonable to conclude that the climate was sufficiently mild to support this necessary abundant flora.

The same conclusion is suggested by the mollusks, and here the result is even more satisfactory, for the species are identical with those living today and we have a much more accurate measure of their habits. The presence of the land shells in the Aftonian is especially suggestive, for land species probably suffer much more from climatic changes than aquatic forms. Moreover they are herbivorous and require a relatively rich flora for shelter. Their presence seems to prove the proximity to the Aftonian streams of plant-covered land areas similar to those which now prevail in the region under discussion, and a climate not materially different from that of Iowa today, at least so far as temperature is concerned.

The presence of the widely distributed manganese dioxide $\left(\mathrm{MnO}_{2}\right)$ in the Aftonian would also suggest large quantities of decaying organic matter* and hence the occurrence of mild seasons.

These facts then go to prove that the Aftonian was an interglacial period with a moderately mild climate, and that there were plant-covered land areas on which numerous animals found shelter and sustenance.

The scattered condition of the bones and the presence of numerous fluviatile shells corroborate the evidence furnished by the structure and composition of the beds that the Aftonian is of fluviatile origin.

\section{Are the Beds Aftonian?}

In view of the importance of these fossils it is necessary that so far as possible the age and stratigraphic relation of these beds be fixed beyond question. It is fortunate that all the species of Aftonian mollusks are still living today and furnish an opportunity for the exact determination of their habits, but that very fact introduces an element of possible error in the determination

* See Geikie's Text-book of Geology, 3d ed., 1893, pp, 63-64, 456-459, and 495 . Also th ed., Vol. I, 1903, p. 585 . 
of the age of the beds if reliance should be placed upon the molluscan fossils alone, for similar or identical series of shells may be collected both in our present waters and in every modern alluvial deposit; and all these species probably invaded the region of Iowa during every interglacial period of Pleistocene time.*

The position of the Aftonian beds between the Nebraskan and Kansan tills has. already been noted in the general Pleistocene section. So far as concerns the two counties under discussion, the position of the Aftonian sands and gravels below Kansan drift was first determined in the Cox pit near Missouri Valley, and the first complete section showing their relation to both the Nebraskan and the Kansan was observed near the county line northeast of Little Sioux, also in Harrison county. Subsequently numerous other sections in Harrison and Monona counties and at other points in western Iowa and eastern Nebraska verified this determination and demonstrated the widespread distribution of the Aftonian.

In order that the evidence, on the basis of which the reference of these beds to the Aftonian was made, may be properly set forth, and to give some conception of the extent of the beds, a detailed description of the principal sections is here presented. Where fossils were found separate lists are also given for each section to show the extent and character of their distribution. For convenience in reference these are given separately for each county.

\section{FOSSILIFEROUS SECTIONS}

\section{Harrison County.}

1. The Cox pit:t-This is located in the southeast bluffs of the Boyer river, in the northeast quarter of section 24, township 78 north, range 44 west, and is one of the finest sections of the entire series. The Aftonian here rises to a height of about thirty-five feet above the Boyer bottoms. The section shows the following:

* For a comparison of the Aftonian, loess, alluvial and modern molluscan faunas see table on p. 395.

†See plate XXV, figure 1, also Bull. Geol. Soc. of Am., Vol. 20, 1909, plate 2, figure 1 , plate 16 , figure 1 and plate 33 , figures 1 and 2 . 
4. Loess, capping the ridge above, but not appearing in the pit.

3. Loveland, exposed just above the pit.

2. Kansan, typical bluish calcareous till, 12 feet(plate $x x v$, figure $1, A$ ).

1. Aftónian:

Sand, varying in coarseness, beautifully cross-bedded, 21 feet. (plate $\mathrm{xxy}$, figure $1, \mathrm{C}$ ).

Gravel, light colored, cross-bedded, with small bowlders, 6 to 8 feet. (plate $x \times v$, figure 1, D).

Gravel, dark colored with much $\mathrm{MnO}_{3}, 6$ to 8 feet.

Fine bluish silt, 6 inches.

White sand, penetrated to a depth of 4 feet.

The Aftonian is typical in structure and composition, ana both gravel beds contained mammalian and molluscan fossils. No fossils were observed in the sand.

The line between the Aftonian and Kansan is very sharply defined, more or less ferruginous, and with Jarge nodular calcareous plates. Aftonian sand and gravel "bowlders," which are scattered through the lower part of the Kansan, also give evidence of plowing by the latter. About thirty-three rods* east of the pit, at Mr. P. R. Cox's house, and about 100 feet above the valley, a well-section aecording to Mr. Cox showed forty feet of yellow clay (evidently loess and prohably Loveland) and blue joint clay (evidently Kansan), below which a great bed of sand and gravel was penetrated to a lepth of eighty-seven feet.

Just south of the road and sonth of the Cox pit on the same slope is the abandoned Diehl pit, from which it is said many bones and teeth were taken when the pit was operated. None of these could be traced, however.

The following fossils were collected in the Cox pit $†$ : MAMMALS:

1. Elephas imperator, lower jaw (plate xxvi, figure 1).

16. Elephas columbi, molar.

12. Mammut americanum, sixth molar (figure to left of.fig. 6, plate xxvi), Mammut americanum, other molars.

*This was erroneously reported as 15 rods in the Bull. Geol. Soc. of Am., Yol. 20. p. 405 .

Hince this paper was set up the following additional mammalian remains were received from the Cox pit::

Ursus-(?) A complete right ramus. It is smaller than that of the grizzly or polar bears, but the compressed canine, here somewhat worn, is quite as large at the base as that of the latter, and exceeds that of the former. This is the first Carnivore obtained from the Aftonian.

Equus scotti, Inferior molar.

Equns - A left tibia.

Cervus (?). Part of left ramus with one premolar and two molars. 
42. (a) Mammut americanum, piece of mandibular tusk (figure just below left end of figure 4 , plate xxvi).

5. Elephas or Mammut, left tibia (plate xxvi, figure 5).

18, 25. Elephas or Mammut, caudal vertebræ.

30. Elephas or Mammut, pubic bone, part.

138. Elephas or Mammut, distal end of radius.

45, 46. Elephas or Mfammut, scapula, fragments (plate xxvi, figure 9).

19. Vertebra, unidentified.

57. Incisor, unidentified.

64. Ruminant, probably Ovibos ——, holn cores (Bull. Geol. Soc. of Am., vol. 20, plate xxiii, figure 1).

83. Astragalus of large luminant (op. cit., plate xxil, figure 1). Piece of cannon bone of. large ruminant (op. cit., plate xxil, figure 3 ).

183. Camelus (?), second right inferior molar.

185. Camelus (?), second phalanx.

67. Large, undetermined ungulate os calcaneum, three specimens

69. Equus $=$, proximal end of radius.

72. Equus ——, ulna, part.

75. Equus …- scapula, part.

77. Equus , three incisors.

78. Equus - , dorsal vertebra.

79. Equиs - astragalus.

80. Eyuus ——- five metatarsals.

81. Equus - humerus, two specimens.

82. Equus - entire tibia and fragments.

85. Equus _- - - distal end of femur.

86. Equus —- first phalanx, three bones.

87. Equus ___ part of large vertebra.

88. Equus - - - distal end of radius, two pieces.

137. Equus —- - distal end of left tibia.

70, 120, 123, 126, 127, 129-135. Equus_—_, molars.

116-119 125, 185. Equus scotti, molars (op. cit., plate xviii, figures 1 to 6 ).

121, 124, 128. Equus complicatus, molars (op. cit., plate xix, figures 1 to 5 , and plate xxi, figures 2 to 4 ).

162. Mylodon - claw (op. cit., plate xxvi).

225. Numerous fragments of bones and teeth.

MOLLESKS:

Unio —- smooth heavy shell.

Unio metanever, one valve.

Unio ——, smooth shell.

2. Peckenpangh sections. - These are located on the east side of the Boyer river near the mill-dam, at Logan, Iowa. There are really three sections, but they lie in close proximity and present the same essential facts.

The largest section was made in quarrying rock just above the dam.*

* See photograph or this section, plate $\mathrm{xxx}$, figure 1 . 
The quarry section shows the following formations:

4. Loess and soil, 20 feet (figure 1, D).

3. Loveland, reddish, somewhat sandy, 6 feet (figure 1, C).

2. Aftonian:

Sand, cross-bedded, 7 feet (figure 1, B).

Coarse ferruginous gravel 2 feet.

1. Missouri limestone, exposed 4 feet (upper surface at $\mathrm{A}$, figure 1).

The water in the Boyer river above the dam is about five feet lower than the bottom of this section.

A well located just opposite the dam and about five rods from the river revealed the following:

4. Loess,

3. Loveland,

23 feet.

2. Aftonian:

Colored sand, 4 feet.

White sand, 5 feet.

Coarse gravel, 2 feet.

1. Missouri limestone, penetrated 4 feet.

The top of the well rises thirty-nine feet above the dam.

The third section is in a sand pit, excavated at the level of the road; which is about twenty-three feet lower than the top of the well. The following section was shown:

2. Aftonian:

Sand and finer gravel, 9 to 12 feet.

Fine silt, about 1 foot.

Coarse. ferruginous gravel, 18 inches.

1. Missouri limestone.

It will be noticed that the Kansan and Nebraskan drifts are wanting in all these sections, but the arrangement of the formaltions present is consistent with the typical section.

The lowest gravel bed is the only fossiliferous part of the Aftonian in these sections. It yielded the following:

Elephas columbi, a good molar, collected north of the middle of the quarry section.

Fragment of a large scapula (?), with the preceding.

Equus (?), a fragment, probably from limb bone of a horse, was taken from the well.

Part of a rib and a fragment of an unidentifed bone were taken from the gravel in the sand pit.

3. Robinson pit.--The Robinson pit is located in the southwest quarter of section 16, township 80 north, range 44 west, and shows a typical Aftonian section with Kansan drift, Loveland joint clay and loess above. The Aftonian rises to a height of 
forty feet above the valley, and is sharply separated from the Kansan by an oxidized band and by large nodular calcareous plates. It contains very little silt, but is made up (luiefly of sand and gravel of the usual Aftonian type.

The following mollusks were collected in the sand:

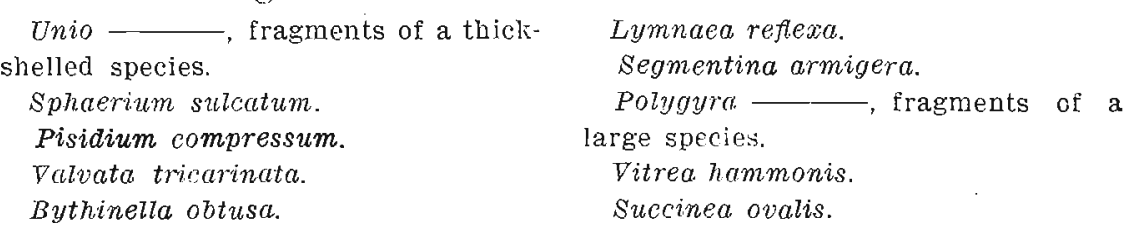

Planoruis parvus

4. Wallace pit.-The Wallace sand pit is located in the bluffs of the Little Sioux-Missouri valloy just north of Sol. Simith lake in the northwest quarter of section 31, township 81 north, range 45 west. This section is cut inte the edge of a narrow bench ant shows that these benches are not ordinary river-terraces but exhibit the usual structure of the uplands. It farcs the great valley and shows the following member's:

4. Loess, rising above the section to the top of the bench.

3. Loveland joint clay, 6 to 8 feet exposed; upper part covercd by slump. In its lower part next to the Kansan it usually contains very large calcareous nodules.

2. Kansan till, typical, 10 feet. Its lowermost line is also marked by large calcareous nodules.

1. Aftonian, exhibiting two distinct phases:

a. Mixed and interstratified sand and silt, 15 feet. The silt is yellow and the sand very fine, the combination resembling very closely that which may be found in most of the modern Missouri river bars.

b. Fine and coarse sand and fine gravel, variously interstratified and cross-bedded, containing the usual soft calcarcous concretions and coneretions and plates of sand and iron oxide. Exposed up to 20 feet ahove the valley but the lower part is covered with talus

The Aftonian sand contained fragments and flakes of a Unio or related musse].

About sixty yards south of this pit Mr. Wallace opened another pit some time ago in which he found the upper Aftonian sand and silt layer reduced to about one foot in thickness, and below it he exposed a bed of gravel sixteen to eighteen feet in thickness. 
On this bench, and several rods from its edge in which these pits are located, Mr. Wallace has a well which he reports to be ninety-five feet deep. It is located at a point about eighty feet above the valley, and its lowest eighteen feet passed through gravel. The gravel is evidently Aftonian, and the well-section shows that these gravels are not comparatively recent formations deposited along the edge of the modern valley.

5. County-line Exposure.-This is a section made by a road cut along the Little Sioux river, in the north half of section 5, township 81 north, range 44 west, less than half a mile south of the Monona and Harrison county line. (See plate XXIV.)

The road is here about twenty-five feet above the Little Sioux river and parallel with it. Three cuts appear in close proximity, making an almost continuous section more than 500 feet in length. The southernmost of these cuts is the best and shows the following :

5. Loess, appearing above the cut, and ascending to top of bluff.

4. Loveland, a reddish joint clay, with lines of very large calcareous nodules, more than 15 feet.

3. Kansan, typical bluish, very calcareous till, 12 fcet.

7. Aftonian:

Fine whitish silt, about 15 feet.

Fine silt, mixed with sand, shell-bearing, 5 feet (figure 1, D).

Coarse gravel, very ferruginous, about 7 feet. This reaches 10 feet in the northernmost cut.

Fine cross-bedded sand 6 to 12 feet.

1. Nebraskan drift, 10 feet exposed, but running out both ways (figure $1, \mathbf{A}, \mathbf{A})$.

1. The Nebraskan is typical blue-black till, breaking up into very small blocks, and containing scattered pebbles and bowlders. It is exposed along the road for a distance of about sixtyfive feet, and its upper line is very irregular, but sharply aefined. The Aftonian, which lies unconformably upon it, has a very ferruginous band at its base.*

2. The Aftonian is more or less variable in the distribution of its materials. In some parts fine silt appears above, and the sand and gravel are variously disposed. However, they shuw the characteristic structure already noted and are typical. Large slabs or blocks of sand-conglomerate are found in the sand beds. The measurements of the several parts of this formation as

*See Bull, Geological Soclety of America, volume 20, plate 34, figure 1. 
given in the section are maxima. At no point do these appear together, the total exposure at any one point being about twenty feet.

3. The exposed parts of the Kansan vary in thickness in the several cuts from zero to fifteen feet. None appears in the northern cut, the Loveland resting directly on the Aftonian.

The Kansan is separated from the Aftonian by a sharp ferruginous line.*

4. The Loveland consists of typical reddish joint clay and varies from eight to more than fifteen feet in thickness.

Fossils were found in the layer of sandy silt, with the exception of the fragments of Unio, which were collected in sand in the northern cut. The list follows :

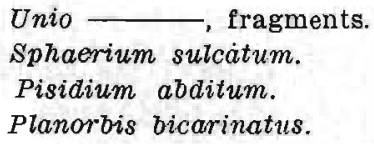

6. Peyton pit.†-This sand pit is located in the northeast quarter of section 23 , township 81 north, range 44 west. The Aftonian here rises about forty feet above the Soldier river bottoms and is at least thirty feet thick. It is made up largely of sand, but with beds and wedges of gravel, and it presents all-the characters of typical Aftonian.

Near the base of the section a bed of white sand six to eight feet thick appears, and just above it, in sand and gravel, a Sioux quartzite bowlder measuring 4 by 2 by $11 / 2$ feet was found.

Mr. Peyton reports a dark blue clay under the sand and gravel. This is probably Nebraskan drift.

The Kansan lies unconformably on the Aftonian, which it has evidently plowed in its upper portions, and is very distinct. It contains numerous Aftonian sand-bowlders.

The following fossils were collected, the mammals in gravel and the mollusks in sand $\ddagger$ :

* See op. cit., plate 34 , flgure 2.

†See Bull. Geol. Soc. of Am., Vol. 20, 1909, plate 16, figure 2.

IRecently two inferior molars belonging to Equus, probably scotti, were added to the collection from this pit. 
MAMLIALS :

2. Mammut americanum, jaw with four teeth (see plate xxvi, figure 2).

4. Elephas (?), part of humerus (see plate xxvi, fgure 4).

6. Elephas imperator (?), femur, four feet long, broken (see plate xxvi, figure 6).

7. Elephas imperator, sixth molar (see plate xxvi, figure 7).

9. Elephas - - (?) scapula, fragment.

157. Limb bone of proboscidean.

18a. Rib, unidentified.

56. Camel, first phalanx (see Bull. Geol. Soc. Am., vol, 20, plate xxl, figure 1, and plate xxil, figure 2).

66. Equus -, acetabulum.

84. Equus , part of metapodial.

Moluds :

Sphaerium sulcatum.

7. Sand-pit in the northwest quarter of section 26, township 81 north, range 44 west.-This sand-pit is located south of the creek and east of the wagon-road, and is only a few feet above the creek bottoms. It shows two or three feet of typical Kansan lying over six to eight feet of mixed sand and Kansan, and below this an exposure of five feet of Aftonian sand. The sand is separated from the Kansan by calcareous nodular plates and an oxidized band, and contained fragments of a Sphaerium, probably S. sulcatum.

\section{In Monona County.}

Monona county furnished a number of fossiliferous sections of which the Elliott pit at Turin is the richest in fossils. A.discussion of the several sections follows:

8. The Elliott pit.-This is a sand pit located in the northeastern part of Turin. The sand and gravel in this pit are typically Aftonian in the cross-bedding, streaking with iron and $\mathrm{MnO}_{2}$, the presence of silt and drift nodules or pellets and white, soft calcareous nodules, and the occurrence of mollusks in the sand and mammalian remains in the gravel.

Moreover, the position of these beds removes all doubt as to their identity. Superintendent W. E. Babcock, of the cement tile factory operating this pit, reports that in boring in the pit they encountered, below the sand and gravel, a layer of "dark clay which was like rubber," into which they penetrated about four feet. They found it putty-like, tough, very hard to work, 
and containing occasional bowlders. This is evidently $\mathrm{Ne}$ braskan drift, which is also well exposed in the same valley at Castana.

The Aftonian was exposed to a depth of about twelve feet. In the greater part of the exposure the fine sand lies above the gravel, though there is some interbedding, but near the south end a layer of coarse, ferruginous gravel rests on the sand.

The bones and teeth were found in gravel at a depth of ten to twelve feet below the top of the Aftonian.

A distinct band of bluish or reddish laminated silt was found above the sand and gravel. It is about two feet thick, and evidently represents a slack-water deposit of the Aftonian. It grades downward into fine sand.

The superimposed formations, the Kansan drift, the Loveland, and the loess, are well developed, and the entire section is typical. The sharp contact line between the Kansan and Aftonian is shown in plate XXVIII, figure 1, A being the Kansan and B the Aftonian.

The following fossils were collected*: VERTEBRATES:

8. Elephas or Mammut, a cervical vertebra (see plate xxvi, figure 8).

161. Part of rib of proboscidean.

166. Mammut americanum, sixth molar.

54. Large ruminant. Distal end of metapodial.

187, 231. Camelus (?) — first phalanx.

122, 136. Equus scotti, superior molars.

227. Equus scotti, inferior molars.

184. Equus complicatus, premolar.

Miscellaneous bones and teeth of Equus: four cannon bones (169); phalanges $(171-172,195)$; a tooth (199); fragments of teeth (228); left radius (232).

197. Jaw of ruminant, fragment.

233. Various unidentified bones, mostly fragmentary.

229. Incisor of a horse (?).

230. Premolar of animal related to camel.

Vertebra of a fish. Found in fine sand.

* Since this paper has gone to the printer the following specimens were received from the Elliott pit:

Elephas columbi, a worn molar.

Proboscidean scapula, fragments.

Equus complicatus, a worn molar.

Equus —-, a splint bone.

Numerous unidentifiable fragments. 
MOLLUSKS:

$\begin{array}{ll}\text { Unio anodontoides Lea. (?) } & \text { Segmentina armigera. } \\ \text { Unio } \quad \text { fragments of a } & \text { Pyramidula alternata. } \\ \quad \text { beavier species. } & \text { Pyramidula striatella. } \\ \text { Sphaerium sulcatum. } & \text { Vallonia gracilicosta. } \\ \text { Pisidium compressum. } & \text { Vitrea hammonis. } \\ \text { Amnicola } & \text { Zonitoides arboreus. } \\ \text { Valvata tricarinata. } & \text { Bifdaria armifera. } \\ \text { Valvata bicarinata. } & \text { Succinea ovalis. } \\ \text { Ancylus rivularis. } & \text { Fragments of two or three other } \\ \text { Lymnaea caperata. } & \text { species. } \\ \text { Planorbis parvus. } & \end{array}$

9. Ordway pit.-This is located in the bluff on the southwest side of the Maple river, opposite Castana, in the southeast quarter of section 13, township 84 north, range 44 west.

The Aftonian here rises about forty feet above the Maple bottoms. The section shows the following members present:

5. Loess, abundant on the ridge above the section.

4. Loveland, 5 to 6 feet.

3. Kansan drift, 6 to 18 feet.

2. Aftonian: Fine, cross-bedded, with interstratified silt, and otber characteristics of typical Aftonian, 5 to 8 feet.

1. Aftonian ferruginous gravel, in part forming conglomerate plates, 3 to 4 feet.

Both this and the following section are on a Kansan sloping bench with no over-lying loess. The loess begins higher up on the slope, and the ridge is capped with a thick deposit of it.

In the northern part of the same pit a layer of gravel three feet in thickness lies under the sand, and contained a stratum of mussel shells (mostly heavy-shelled Unio) in which the shells were closely massed. They were very fragile and could not be taken out entire. . With them were shells of Sphaerium sulcatum and a shell of Ancylus rivularis. Several large bowlders rested on this gravel layer.

The finer sand contained the following mollusks:

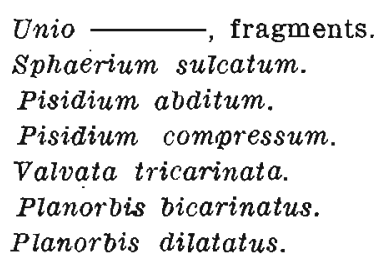

\author{
Segmentina armigera. \\ Physa integra (?). \\ Ancylus rivularis. \\ succinea retusa. \\ succinea avara.
}


10. Orduay well.-This well was excavated on the same terrace-like slope, about an eighth of a mile northeast from the pit.

Measurements of the well section could not be made, but it was plain that the Kansan reaches the surface here, and may be traced upward for thirty feet more (vertically) before it disappears under the loess which covers the ridge in its upper parts. In the well itself bluish Kansan till was clearly discernible. Below this Aftonian sand, with a little gravel, rested on a deep bed of Nebraskan drift.

An examination of the materials brought up from the well corroborated the correctness of the record. The sand is here clearly interglacial, lying between the Kansan and the Nebraskan drift sheets, and hence Aftonian.

The sand in the well section yielded the following fossils:

Unio - fragments.

Sphaerium sulcatum.

Pisidium compressum.
Valvata tricarinata. Planorbis bicarinatus.

Some years ago a fragment of a large scapula was obtained from an old gravel pit near this well, and it has been added to the collection (number 91).

11. Griffin well.-This is located near Mapleton, on the farm of C. H. Griffin, on the east side of section 17, township 85 north, range 42 west. It is situated in a rolling Kansan area about fifty feet above the valley of Heisler creek.

The section was made through loess, Kansan drift, and into Aftonian sand and gravel to a depth of about forty feet. The writer examined the material taken from the well. Moreover, Kansan appears at the surface on the same slope at a lower level, the loess covering only the upper parts of the ridge. At a depth of thirty-five feet a part of the tooth of Elephas imperator was found in the gravel.

12. Wilkenson well.-This is located in the northwest quarter of section 6 , township 85 north, range 42 west. Here, in a typical Kansan drift region, a large tusk (234), a molar, nearly eight feet long on the outer curve, and fragments of cranial bones (numbers 204-211) of Mammut americanum were found at a depth of about thirty-five to forty feet, in loose sand and gravel. This section is similar to number 9 . 
13. Hawthorn pit.-This is a sand and gravel pit in the same region, being located in the northwest quarter of section 14, township 85 north, range 43 west.

The section is typical, showing loess, Loveland, Kansan drift, and Aftonian, the latter here chiefly sand. Mr. C. A. Hawthorn discovered bones in this at various times, but none were saved.

14. McCleary pit.-This is also located in the same region, in the southwest quarter of section 1, township 84 north, range 42 west. The pit is remarkable because it is situated more than two miles inland from the line of the Maple river bluffs, on a small tributary creek. It shows distinct plowing by the Kansan, which here lies distinctly above a stratum of typical Aftonian sand, with some gravel, about twelve feet in depth. The owner reported that in the gravelly portions of the pit he has found "regular clam shells."

15. The New Wooduard section.-This is a new sand pit located in the southwest quarter of section 9, township 85 north, range 44 west, about two miles southwest of Rodney. The exposure shows about three feet of fine, white, cross-bedded sand, containing shells of molluslss, and above it an irregular mass of sand and gravel about eight feet deep.

The material lying above the sand is not clearly defined, on account of slumping, but it is mixed drift and gravel, such as is common in this region, where the Kansan plowed into the upper part of the Aftonian.

The sand contains silt balls or pellets, such as are common in the Aftonian, and in all respects the structure and composition of the beds are typical. Moreover, several sections in the vicinity show the unmistakable presence of the Aftonian, one, located in Woodwards Glen in the southwest quarter of section 17, showing a distinct layer of Nebraskan drift immediately below the Aftonian.

The following mollusks were collected in the white sand in section 15:

Pisidium compressum.

Sphaerium -, probably S. sulcatum, fragments.

Lymnaea.—, probably L. humilis, broken. 


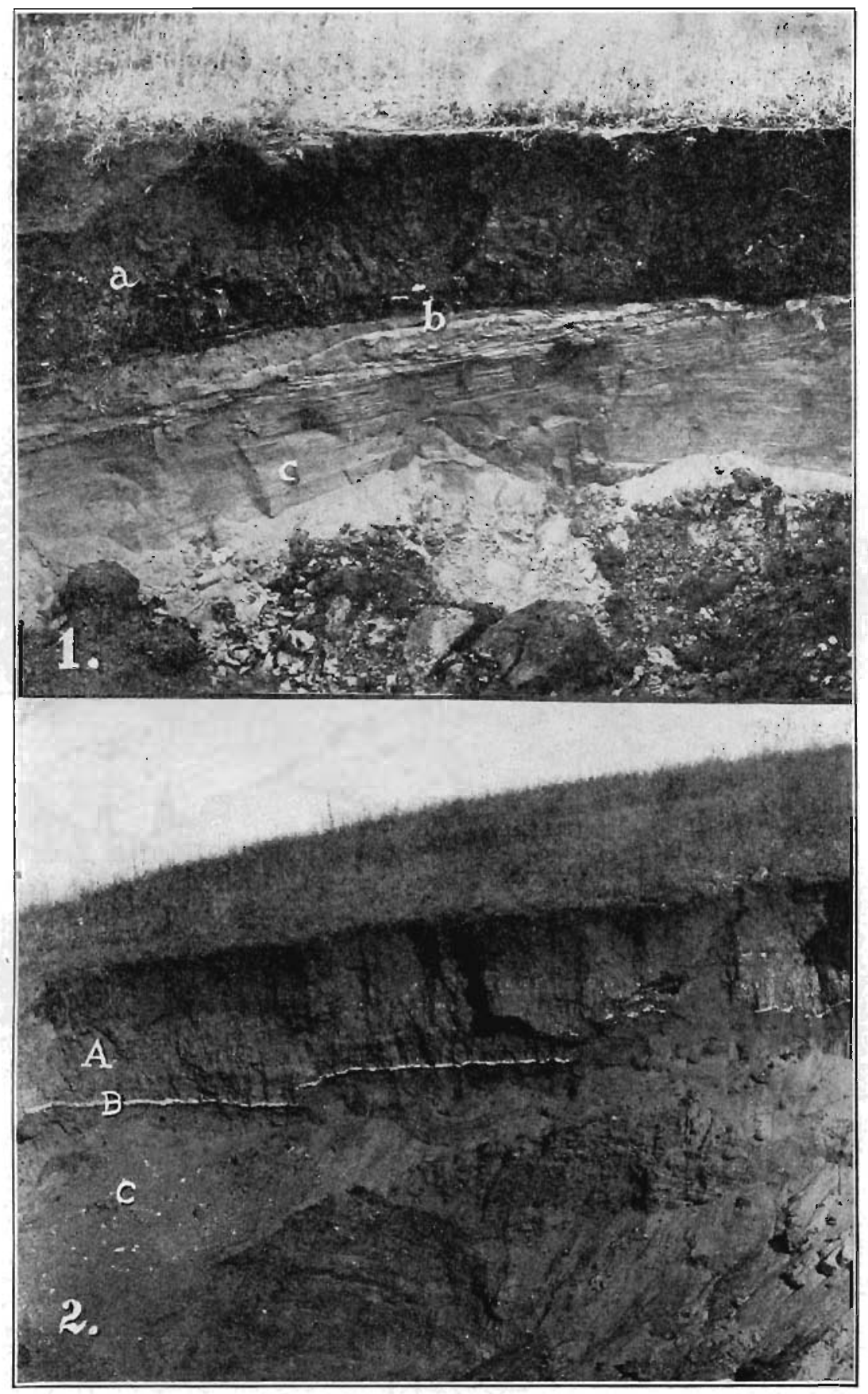

Plate XXVII.-Kansan on Aftonian. (1) In northwest quarter section 7, township 85 north, range 44 west. (a) Kansan. (b) Narrow ferruginous band. (c) Aftonian sand (p. 359). (2) Weniger pit. (A) Kansan. (B) Calcareous nodular
plates. (C) Aftonian sand (p.347). 
16. Weniger pit.-This is a sand pit located in the east half of section 18, township 84 north, range 44 west, in Monona county, in the bluffs facing the Missouri valley. (See plate XXVII, figure 2.)

It shows eight feet of sand and gravel (figure 2, C) on which typical Kansan drift, two to four feet thick (figure 2, A), rests unconformably. The two deposits are separated by a distinct oxidized band and by a layer of calcareous nodular plates. (See figure 2, B.)

The Aftonian here rises to about forty feet above the Missouri bottoms, the average altitude of these beds in this territory.

Fragments of shells, probably Sphaerium, were found in the upper, finer sand.

Some question may arise as to whether the foregoing fossils really belong to the Aftonian, or were derived from other formations. Fossils from older formations are sometimes found in the Aftonian, as well as in the drifts, and a similar origin might be suggested for the fossils herein enumerated. The mollusks occur in various alluvial and loess deposits, but these uniformly overlie the Aftonian beds and moreover the fragile chalky shells would be destroyed by transportation with the coarse Aftonian materials.

The mammalian remains are especially subject to the suspicion that they are derived from older formations. However, the excellent preservation of the fossils, their distribution and abundance, the occurrence of parts of the same skeleton in such position that ligaments evidently united them at the time of transportation, the position of tusks and teeth in their sockets so loosely attached that they were easily removed, the absence of these fossils from the drifts above and below and the fact that the fauna as a whole is not known from any clearly older horizon, all give strong testimony that the fossils are really contemporaneous with the Aftonian beds in which they lie.

SECTIONS IN WHICH NO FOSSILS WERE FOUND.

In addition to the sixteen fossiliferous sections already described, ${ }^{*}$ at least fifty exposures of Aftonian in which no fossils have been found were observed within the limits of these counties,

* For a description of additional fossiliferous Aftonian sections in other parts of Iowa and In Nebraska, see Bull. Geol. Soc. Am., Vol. 21, pp. 119-140. 
in sand pits, aleng the bases of blufis, in road-cuts, well-sections, etc. Some of these sections throw much light on the Pleistocene history of this territory, and for that reason the more important are described in detail.

One feature which so far as observed is best displayed in many of these non-fossiliferous sections, though also present in the uppermost portions of some of the fossiliferous sections already described, is wortly of special attention. This is the evidence of the disturbance and plewing of the Aftonian and Nebraskan beds by the Kansan ice-sheet which passed over them. The Kansan drift overlying the Aftonian frequently contains bowlders of sand and gravel, and more rarely of Nebraskan drift, evidently introduced when the Kansan ice-sheet plowed the underlying beds to a greater or lesser depth and incorporated frozen fragments of them in its own mass. Similar bowlders have already been described by Calvin from the Thayer-Afton region in southern Iowa." But more striking than the testimony of these bowlders is the evidence furnished by the variously folded and distorted strata of the usually cross-bedded or stratified Aftonian sands and gravels which have in some cases been forced into a vertical position or even folded back upon themselves by the Kansan ice. In such cases the line between the Aftonian and Kansan is variously bent and folded as shown in several of the sections described (see plate XXV, figure 2, plate XXVII, figure 2, and plate XXVIII, figure 2), and above it detached fragments or "bowlders" of Aftonian sand and gravel are common. In some cases huge masses of Aftonian were thus set up on edge and pushed far up above their normal level, and occasionally the point of the Kansan plow may be clearly. seen back of the disturbed masses of Aftonian, as in the McGavern, Murray bill and other sections. These twisted and distorted masses indicate that the tremendous pushing and crushing force came from the north or northeast, which is consistent with the recognized direction of the Kansan ice movement in this region. The peculiarities of these disturbed strata are brought out in the detailed descriptions of the sections which follow.

*Proc. Davenport Acad. of Science, Vol. X, 1905, pp. 28-29. 


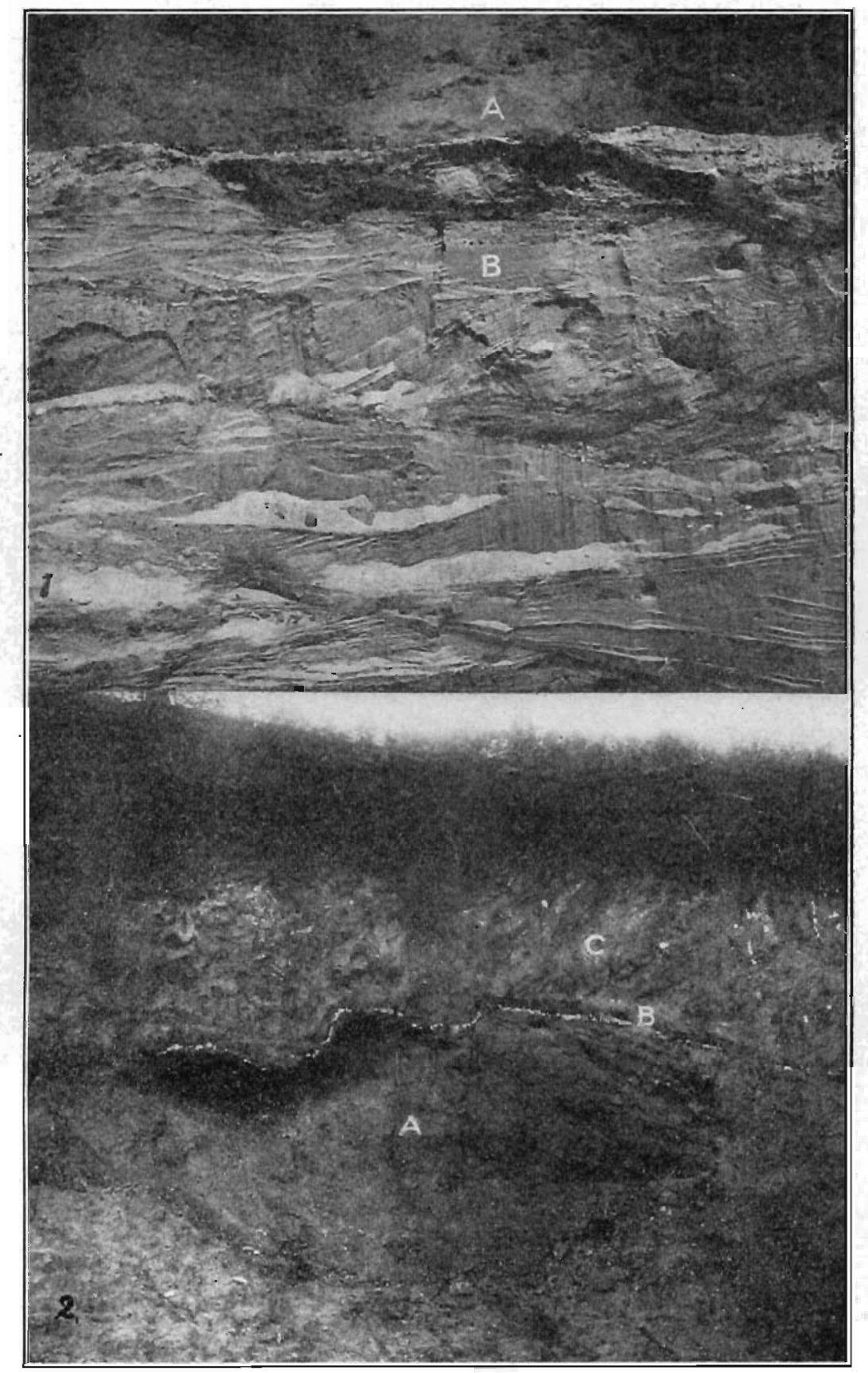

Plate XXVIII.-Kansan and Aftonian. (1) Elliott pit. (A) Kansan. (B) Aftonian sand (p. 341). (2) Ferdig pit. (A) Aftonian sand. (B) Folded layer of calcereous plates. (C) Kansan (p. 358). 
p. $[350]$

( V.20) 


\section{In Harrison County.}

17. McGavern pit.-The remarkable section displayed in the McGavern sand-pit south of Missouri Valley, in the southeast quarter of section 27 , township 78 north, range 44 west, has already been described and figured by Calvin,*, and also by the writer. $\dagger$

The pit is located on the rounded point or angle formed by the Missouri and Boyer valleys on the south side of the latter. Its base as exposed when examined was about forty-five feet above the valley of the Missouri and the total height of the exposed section was about eighteen feet. The southeast face of the section, the upper portion of which is represented in plate $\mathrm{XXV}$, figure 2 , showed a horizontal bed of cross-bedded sand and gravel, about three feet in thickness, which seemed to be practically undisturbed, but it was impossible to determine whether this is a part of a lower undisturbed stratum of Aftonian, or merely a portion of the disturbed mass which had been accidentally left in a horizontal position. Above this layer, and just below (A) in the figure, there is a bed of sand eight feet in thickness, which has evidently been pushed and crowded so that its crossbedded wedges and strata are variously tilted and folded (see C. C). To the right of (A) this bed, which here contains streaks of fine gravel, is folded upward and rises to the top of the section. It is evident that this part of the Aftonian bed was pushed and distorted by the Kansan mass (A) until some portions were folded back through an angle of more than 90 degrees. Excepting for the folding the Aftonian is typical, consisting of strata of sand and fine gravel, the former predominating, which are marked by occasional streaks and stains of $\mathrm{MnO}_{2}$ and iron oxide.

The Kansan mass at (A) is about seven feet thick, but varies irregularly to much less than that in other parts of the section. The Kansan consists of typical bluish till which is here very calcareous. The great pressure of the Kansan mass upon the frozen Aftonian sand and gravel resulted in the development of a concentric lamination in the till which follows the irregular line

*Bull. Geol. Soc. of Am., Vol. 20, p. 140, plate 3, fig. 2.

tOp. cit., Vol. 20, p. 406 , plate 36 , flgures 1 and 2 . 
between the Kansan and Aftonian (at B, B). The Aftonian sand slows a similar lanination near the line of contact.

This section is of special interest because, to cuote from Caivin's description, "here is a mass of deformed and displaced Aftonian, an enormous sand and gravel bowlder, and here, in the exact position assumed while the work was being done, is the agent through which was transnitted the shove and thrust recorded in the distorted gravels."

18. Persia pit.- In the west bluff of Mosquito creek, one block south of the Chicago, Milwaukee and St. Paul railway depot at Persia, and about twenty-five feet above the valley, there is an old sand-pit which also illustrates the effect of the Kansan plowing. Here there is an irregular mass of Kansan till containing numerous pockets of sand, evidently Aftonian sand-bowlders, for they show the cross-bedding and other characteristic features of that formation. Scme of these are so large that they lave been worked as sand-pits.

19. Mefferd pit-This sand-pit, owned by G. L. Mefferd, is located in the southeast quarter of section 31, township 80 north, range 41 west, on the sonth side of a small creek. The Aftonian has been exposed here to a depth of ten feet, and consists of sand which passes below into fine gravel. It is typical cross-bedded Aftoniam, with ferruginous and $\mathrm{MnO}_{2}$ stains, and is separated from the overlying Kansan by calcareous nodular plates. The Kansan is typical, very calcareous till, and the portion exposed is from three to eight feet in thickness. The ridge above the section is covered with loess. A few rods farther down the creek outcrops of the Kansan and Aftonian appear in a bank twenty feet high, but here in the lower six feet the Kansan is folded and contains bowlders or pockets of coarse sand and gravel.

20. Sand-pit in the northeast quarter of section 28, township 80 north, range 42 west.-This sand-pit is located about two and one-half miles soutluwest of Woodbine, and more than twenty feet above the valley. It shows Aftenian gravel and sand-beds variously folded and twisted, and containing bowlders of silt covered with a white calcareous deposit. Above and back of these masses of gravel intricately folded Kansan appears, the whole mass shown in the section having evidently been folded and crumpled together. 


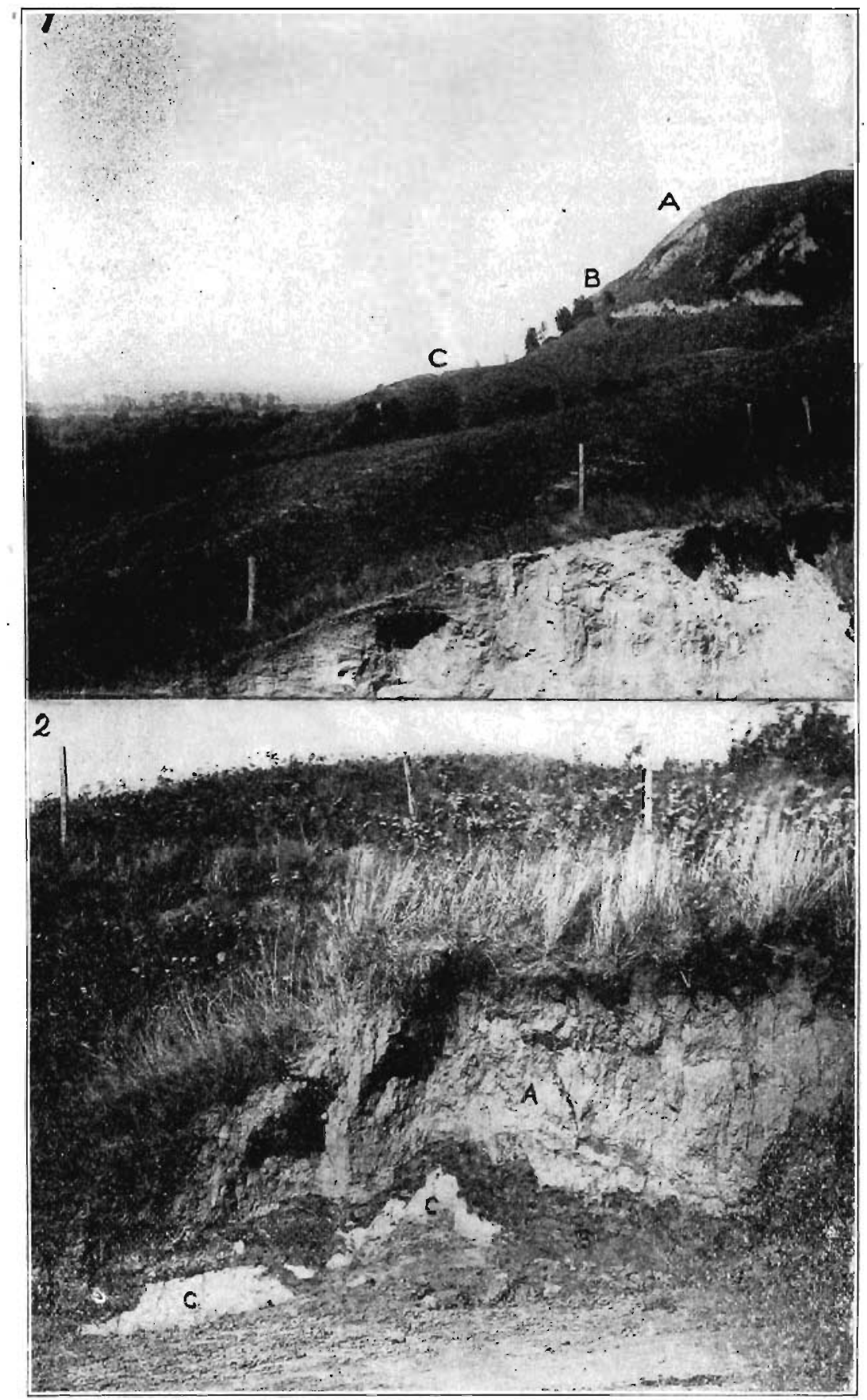

l'lue XX1X.-Murraly thill exposures. (1) Protile, Inoking north (pp. 280, 355.) (2) section along road. (A) Kansin. (B) Ferruginols Aftonian gravel. (CC) Aftonian white sand $(p, 355)$. 
21. The Murray Hill-section.-Murray hill is located in the southeast quarter of section 8, township 81 north, range 44 west, and the section here discussed is exposed in part by the road which ascends the hill.* The section is of great interest because it shows the Aftonian sand and gravel crowded and piled up to a height of at least 120 feet above the valley, the highest point at which the Aftonian has been observed. The entire section gives unmistakable evidence of the overwhelming force of the Kansan ice.

The section is more or less interrupted and that part displaying the Aftonian follows the road for a distance of more than 800 feet and rises from the valley to a height exceeding 120 feet. Along almost the entire section, and especially between the altitudes of thirty and $\mathbf{1 1 5}$ feet above the valley, there are exposures of Nebraskan, Aftonian and Kansan variously folded. (See plate XXIX, figure 2.) At an altitude of about seventy feet the $\mathrm{Ne}$ braskan rises ten feet above the road, and was here, as at other points in the section, folded and strongly laminated by the pressure of the Kansan mass which still lies back of it. At eighty-five feet a sand-pit shows, in its upper or eastern part, the following section:

3. Kansan drift, 6 feet.

2. Aftonian:

Sand, 8 feet.

Gravel, 6 feet.

1. Nebraskan drift, irregular band exposed.

The lower or western part of the pit shows a mass of sand and gravel which seems to be standing almost on edge. So violent was the action of the Kansan ice that in some places the $\mathrm{Ne}$ braskan is folded and pushed into or over the Aftonian.

A profile of Murray hill is shown in plate XXIX, figure 1. The portion marked (C) is made up largely of Aftonian, but the Kansan drift has slipped over it and is discernible toward the base, but in the upper part of (C) the Aftonian comes to the surface. Loess is also present on the southwest slopes of (C). The upper part of the sand-pit section reaches almost to the top of (C). Farther up the slope, at (B), the Loveland joint-clay, ex-

*This section has been in part described and figured in the Bull. Geol. Soc. of Am., Vol. 20 , p. 406 , plate 37 , figure 1 . The ridge which it follows is shown in plate XXI, figure 1, ascending from the left end of the grove to the more abrupt loess slope above. 
posed to a depth of at least ten feet, rests upon the Kansan, and above it, and separated by a sharp line, is a yellow fossiliferous loess, (A).

In addition to the foregoing several minor sections were ob. served in Harrison county, and without exception they were consistent in structure and position with those already described.

Some of the best of these are located as follows: the John Hull pit in the northwest quarter of section 3, township 78 north, range 43 west; the Fred Mefferd pit in the southeast quarter of section 28, township 80 north, range 41 west; the Tuttle pit in the southwest quarter of section 24 , township 80 north, range 42 west; the sand-pit in the northeast quarter of section 28 , township 80 north, range 42 west; an old sand-pit near the middle of the west line of section 10 , township 78 north, range 44 west; the Jardine pit north of the Robinson pit in section 16, township. 80 north, range 44 west; the Hagerman pit south of the Robinson pit; an irregular exposure of sand and drift along the road between sections 17 and 18, township 81 north, range 44 west; and a similar exposure nortl of the county line exposure near the north line of section 3 , township 81 north, range 44 west.

Well-sections in various parts of Harrison county also reveal sand and gravel which are certainly or probably Aftonian, and further demonstrate the important fact that the Aftonian beds extend far beyond the limits of the present river valleys. The well records here presented possess added interest because they throw additional light on the structure of the benches which so prominently border the larger river valleys, for these wells are all located on benches.

The following records are of interest:

At Dunlap.-Mr. David Tacy, a well-digger, reports that in the northern part of the Dunlap bench he finds gravel (it is probably Aftonian), at a depth of sixty-five feet.

At Woodbine.-Mr. Theodore Warren, a well-digger, reports the following usual section for the northern part of the Woodbine bench:

Yellow clay (evidently loess), 25 to 40 feet.

Blue-gray clay (probably Kansan till or post-Kansan loess), 4 to 10 feet. 
Blue fine sand, and beneath it a coarser ferruginous sand.

He also reports less sand and more coarse gravel in the southern part of the same bench.

At Logan.-Mr. J. C. McCabe had a well dug at his residence on the Logan bench, and at a depth of sixty-two feet sand was encountered, and beneath it a layer of gravel. On this sand rested a layer of heavy blue clay (probably Kansan till), and above that was the usual covering of yellow loess. A comparison of this section with the Peckenpaugh sections on the opposite side of the Boyer demonstrates quite clearly that the sand and gravel found in the Logan bench are Aftonian.

On the bench southeast of Logan on the opposite side of the Boyer Mr. R. H. Reed reached sand at a depth of seventy feet, in digging a well in the northeast quarter of the northwest quarter of section 30, township 79 north, range 42 west, and $\mathrm{Mr}$. R. Hill obtained the same result in the southwest quarter of section 19, township 79 north, range 42 west.

\section{In Monona County.}

Exposures of Aftonian which have not yet yielded fossils are even more numerous in Monona than in Harrison county, but they are mostly small pits and it is more than probable that more extensive excavations will transfer many of them to the fossiliferous list. Similar slight excavations in the upper parts of the Cox and Peyton pits would have exposed no fossils, notwithstanding their abundance in the lower strata.

The more noteworthy of these exposures follow:

22. Sand-pit in the southwest quarter of section 35, township 84 north, range 44 west.- This pit lies above the road, and shows the Kansan and Aftonian intermixed and folded. The Kansan may be traced along the slope above the pit for some distance.

23. Pinckney pit.-This sand-pit is located in the southwest quarter of section 30 , township 85 north, range 42 west, southeast of Mapleton, on a hillside about twenty-five feet above the creek valley, which is here about eighteen feet above the bed of the creek. (See figure 29.)

The section exposed was as follows:

5. Loess, 2 to 3 feet (a) in figure.

4. Loveland, $1 / 2$ to $11 / 2$ feet (b). 
3. Kansan, a wedge running out at the west end, where the Loveland rests directly on the Aftonian (c).

2. An oxidized band with calcareous nodular plates, 1 to 3 inches (d).

1. Aftonian, consisting of a layer of coarse gravel about 1 foot in thickness (e), resting on 2 feet (exposed) of fine sand (f).

24. Old Hawthorn pit.- This sand and gravel pit is located on a hillside about forty-five feet above the valley of Wilsey creek in the southeast quarter of section 14, township 85 north, range 43 west, northwest of Mapleton. It shows evidence of great disturbance, the Kansan till and Aftonian gravel being folded and inter-bedded in the upper part of the section in a complicated manner. Manganese dioxide is very abundant in the gravel. The lower part of the section shows several feet of tilted strata of sand and gravel.

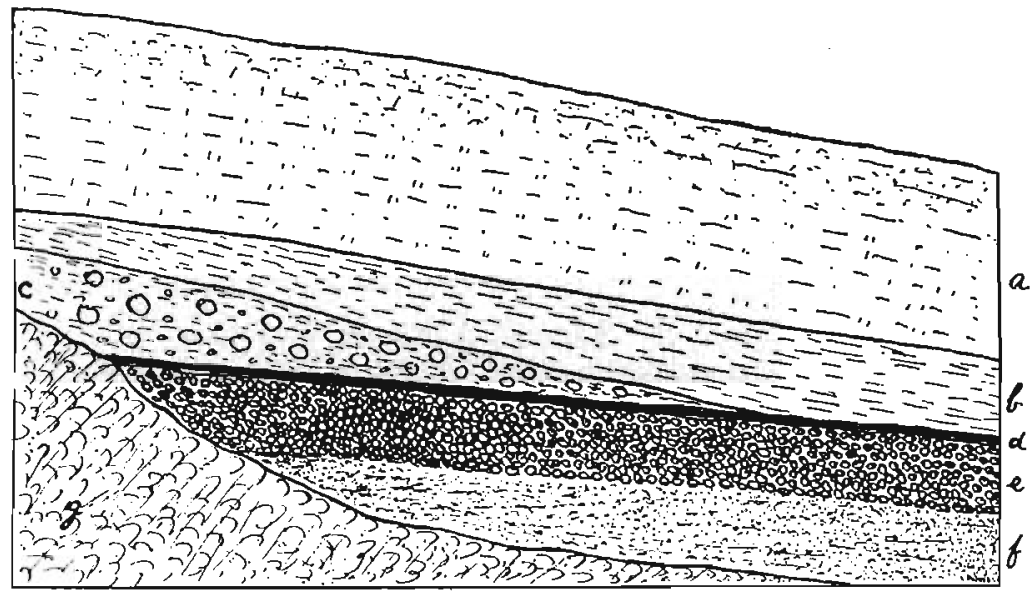

Figure 29. Section of the Pinclney sand pit, southeast of Mapleton.

25. Ferdig pit.-The Ferdig pit is located near the southwest corner of section 10, township 85 north, range 43 west, on a slope some distance from the creek valley. (See plate XXVIII, figure 2.)

The section presented the following members:

4. Loess, 1 to 3 feet.

3. Loveland, 2 to 3 feet, its line of contact with the Kansan irregular, and marked by a band of fine silt 5 to 8 inches thick.

2. Kansan, 4 to 6 feet (c), mole or less folded, becoming thicker laterally, and separated from the following by distinct stratum of white, calcareous nodular plates at (b).

1. Aftonian, about 8 feet of typical cross-bedded sand exposed (a). 
The irregular calcareous line between the Kansan and Aftonian is especially prominent, as is clearly shown in the figure.

26. Sand and gravel pit in the northeast quarter of section 30 , township 85 north, range 44 west. - This pit is located on the detached knob south of the Chicago, Milwaukee and St. Paul railroad near Grant Center. The gravel here rises to a height of fifty feet above the valley, and is exposed along the surface of the slope, and also in three artificial excavations. The one on the northern slope shows three to four feet of Kansan above the gravel, but in the other two which are on the west slope the gravel extends to the surface. A twelve-foot well and borings from fourteen to twenty-five feet in depth, penetrated into but not through the bed of sand and gravel.

The upper part of the Aftonian has been somewhat disturbed, and the overlying Kansan may be traced on the slope to a height of eighty feet above the valley.

27. Sand-pit in the northwest quarter of section 7, township 85 north, range 44 west.--This exposure presents the following section:

2. Kansan, typical calcareous till, plate $x x v i i$, figure 1 (a), 2 to 3 feet, its lower limit marked by an oxidized band (b), 2 inches in thickness.

1. Aftonian, a bed of fine stratified and cross-bedded sand, 4 feet exposed, separated from the Kansan by a layer of calcareous nodular plates interstratified with sand which form a band 1 foot in thickness (c).

28. Blakely pit.-The Blakely pit is situated near the middle of the west line of section 20 , township 85 north, range 44 west. The exposure is irregular. At a height of thirty-five feet above the valley a stratum of cross-bedded sand two feet in thickness is exposed beneath distinct Kansan. Reaching to an altitude of forty-five feet above the valley is a section of a bed of tilted cross-bedded sand and fine gravel, four feet exposed, which was more or less folded by the shove of the later Kansan ice.

29. Woodwards Glen section.-.This section appears in a high bank of the east fork of the ereek in the southwest quarter of section 17, township 85 north, range 44 west. It revealed the following members: 
3. Kansan, with the upper part of the bed evidently a secondary depusit, 16 to 18 feet.

2. Aftonian, cross-bedded, ferruginous sand and gravel, 5 to 6 feet.

1. Nebraskan drift, typical, 1 to 2 feet exposed above the creek bed.

Another section reported from the same region by Bain" shows no Nebraskan, and its sixth member is probably not loess, but a secondary silt deposit, at least in its lower part.

30. Aldrich and Young pit.--This pit is situated near the north line of section 12 , township 85 north, range 44 west. The section consists in the main of tilted Aftonian gravel beds, with some sand, separated from the overlying Kansan by calcareous nodular plates. The Kansan rises high above the Aftonian bed and forms the main part of the lower ridges bordering the valley of the Little Sioux.

31. Sand-pit in the southwest quarter of section 27, township 85 north, range 44 west.-This is a small exposure facing the valley of the Little Sioux, and shows two feet of Kansan resting on three feet (exposed) of Aftonian sand, with the usual calcareous nodular plates separating them.

Turman pit.-This pit, which lies just north of Monona county, at Smithland, is worthy of mention in this connection because it furnishes additional testimony of the crushing power of the Kansan ice in this region. Here the Aftonian, Nebraskan and Kansan are folded in intricate fashion, and sand and joint-clay bowlders of Aftonian and Nebraskan origin are conspicuous in the Kansan.

Numerous small exposures were also observed in Monona county. Along the main bluffs within the first three miles north of the south line of the county ten or twelve such exposures were observed along or above the wagon road; two small pits are located in the southwest quarter of section 34, township 83 north, range 44 west; a gravel pit showing overlying Loveland is located in Crabb's bluff in the northwest quarter of section 27 , township 83 north, range 44 west; another is on the east side of section 33, township 84 north, range 44 west; in the southeast quarter of section 19, township 85 north, range 44 west, there are two exposures; another is located near the center of section 19;

*Rep. Iowa Geol. Sur., Vol. V. 1896, where the region is designated as "Wroodwarth's Glen." 
another, in the north half of section 19, shows plowed Aftonian gravel twenty-five feet above the road; on the south line of section 18, township 85 north, range 44 west, Aftonian appears, with Kansan rising above it to a height of 140 feet above the valley; Aftonian sand and overlying Loveland are exposed in the southeast quarter of section 17 , township 85 north, range 44 west; and a small pit is located in the northwest quarter of section 27 , township 85 north, range 44 west.

Several well-sections are of great interest not only because they again show the structure of the river-valley benches, but because they also demonstrate that the Aftonian beds extend much beyond the present valleys of the larger streams and are not mere river terraces. The following well-records were obtained from various sources.

At Soldier.-A well-digger at Soldier reports that on the bench on which the village stands he finds fifteen feet of yellow clay (evidently loess), a layer with many calcareous nodules, a harder clay (the two latter probably Kansan) and at fifty feet he reaches sand, probably Aftonian.

Mr. David Tacy, a well-digger of Castana, gives in substance the following report on the Belvidere and Castana benches:

On the Belvidere bench.-On the farm of Mr. Chas. Bisbee, located on the Belvidere bench in section 11, township 83 north, range 44 west, gravel was reached at a depth of about 125 feet. Above this was blue clay, and then yellow clay (loess) to the surface.

At Castana.-On the lower part of the Castana bench yellow clay (loess) is uppermost and reaches a depth of thirty to forty feet; then follows a layer of blue clay (evidently usually Kansan but sometimes probably including post-Kansan loess) varying from three to twenty-five feet in thickness, and this is followed by gravel.

The depth at which gravel is reached varies from about ninery to 130 feet according to the height of the bench.

At Mapleton.-Mr. W. M. Osborne of Mapleton reports that on the Mapleton bench be usually reaches sand at a depth of about forty to forty-two feet, and above this he finds seven to eight feet of a bluish layer which is limy (evidently Kansan), and on this and reaching the surface, is a yellow clay (loess). 
The Griffin well already described is also on a similar bench.

While the identification of the members above the Aftonian is not always satisfactory, it is very evident that these well-sections show a stratigraphic arrangement which is consistent with the general sections, and that the sand and gravel belong to the Aftonian.

The foregoing sections which were studied in Harrison and Monona counties show beyond doubt that the sands and gravels here referred to the Aftonian occupy a consistent position below the Kansan drift, and between it and the Nebraskan drift; that they are unconformable with both and separated from them sharply by strongly oxidized ferruginous bands suggesting old surfaces representing long time-intervals; that the Kansan isesheet passed over them and plowed and disturbed them to a greater or less extent while they were frozen; that they represent an interglacial interval in which great floods moved enormous masses of gravel, sand and silt, and during which plant and animal life was abundant; that they are of much wider extent than modern river-valleys, and hence cannot represent marginal deposits of modern streams over which the materials of older deposits had slipped and slumped; and that in short they truly belong to the Aftonian interglacial interval.

The thickness of the Aftonian beds is variable, but where they are not disturbed by the Kansan, it does not exceed forty-five feet, which also represents about their usual height above the alluvial plain of the Missouri river and its larger tributaries.

Where the base of the Aftonian rises somewhat above the valley springs are abundant, the Aftonian being a great waterbearing stratum resting upon the almost impervious Nebraskan drift. Such springs are common on the Missouri valley side north of Grant Center in Monona county, and thence they occur southward at intervals along the bluffs in both Monona and Harrison counties. They are especially abundant between Crescent and Council Bluffs in Pottawattamie county, and at Florence and South Omaha on the Nebraska side of the Missouri. So generally does this horizon furnish springs that wherever water issues from the bluffs in this territory it is worth while to search for Aftonian gravels. 


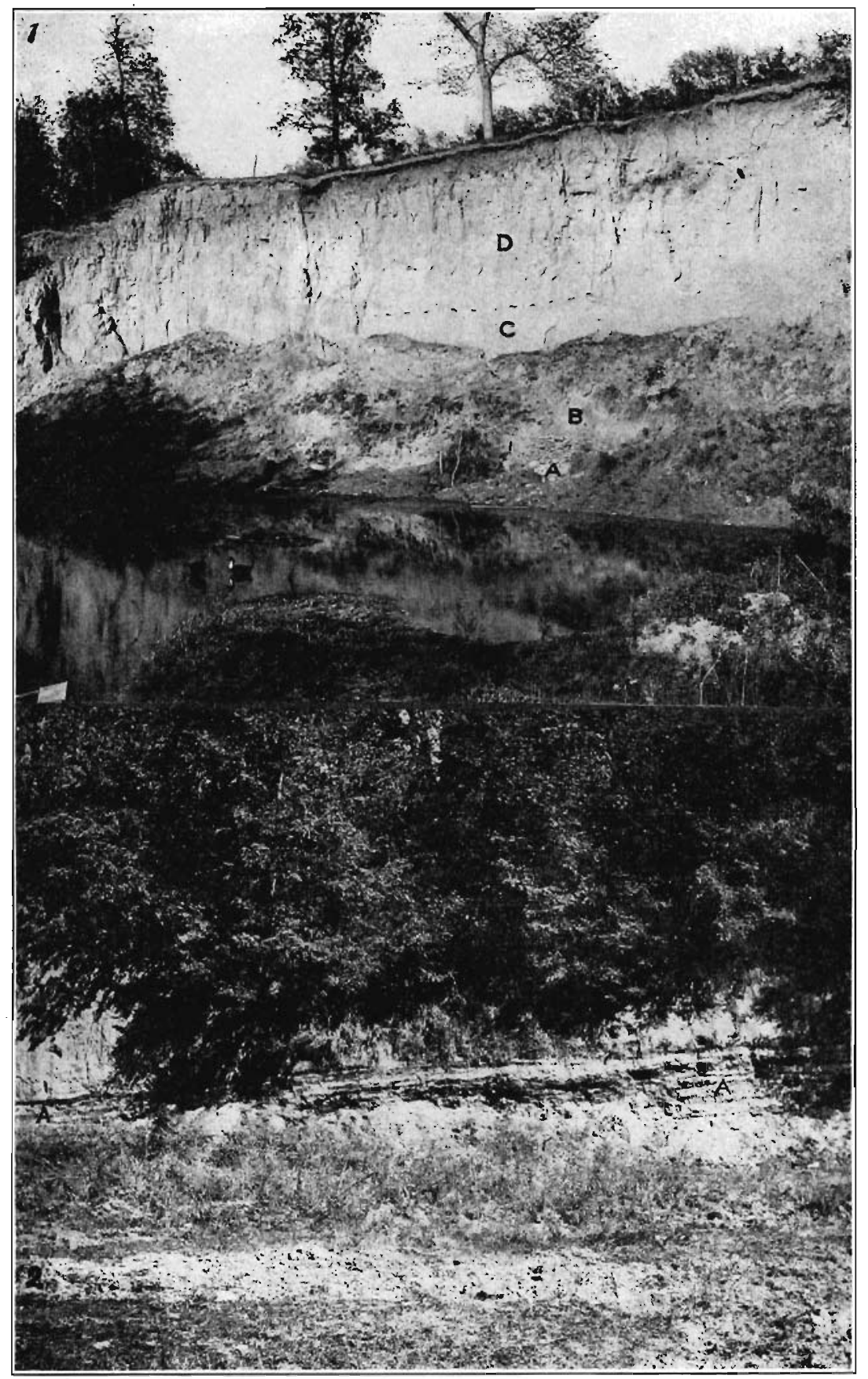

Plate XXX.-Harrison county exposures. (1) Peckenpaugh quarry section. (A) Top

of Missouri limestone at base of rock wall. (B) Aftonian sand. (C) Loveland. (D) Yellow loess ( $\mathrm{pp} .301,335$ ). (2) $\mathrm{MnO}^{2}$ bed in Snyders Hollow. (AA) Northern part of exposure. (p. 365 ). 
P. $[3204]$

(v.20) 
SNYDERS HOLLOW SECTION.

A discussion of the Aftonian sections of this territory should not be completed without some reference to a unique deposit which is prominently exposed in Snyders Hollow just north of Missouri Valley, and which is probably Aftonian. (See plate $\mathrm{XXX}$, figure 2, AA.)

The section is exposed along the east side of the first lateral ravine extending to the south. It is more or less interrupted and obscured by slumping and overwash, but the northern part, which is shown in the figure, exhibits the structure and composition clearly. The entire exposure is more than 200 feet long, and shows at the base a mass of inter-stratified black manganese dioxide $\left(\mathrm{MnO}_{2}\right)$ and white marly calcium carbonate, the upper line of which rises above the flat bottom of the valley from zero at the north end to twelve feet at the south end.

The clear northern section of this stratum is about seventy-five feet long, and from zero to eight feet high. Just opposite its higher end a shallow well shows that at this point the black and white stratum extends about two feet below the surface, and that beneath it there is a layer of silt similar to that which overlies it. The lower silt was exposed in the well to a depth of two feet.

The black bands and layers of $\mathrm{MnO}_{2}$ are made up of fine loose material, or they are consolidated into very hard plates. They vary from mere streaks to layers several inches in thickness, and contain very few fossils.

The white calcareous bands are equally variable in thickness as well as in texture, being sometimes soft and chalky and again forming nodular masses. Rarely narrow bands of silt are interstratified with the $\mathrm{MnO}_{2}$ and calcareous layers. They are very fossiliferous.

Above this stratum lies a band of rather dark silt from one and one-half to two feet in thickness which is also fossiliferous. All of these fossils are listed in the comparative table of mollusks on page 395 .

The uppermost part of this section is made up of a stratum twelve feet in thickness which consists of a sparingly fossiliferous yellow loess somewhat modified below. It is possible that this lower portion represents the Loveland. 
The absence of several members of the usual Pleistocene series makes it very difficult to determine the stratigraphic position of the manganese and silt beds, but the rather scant evidence at hand would point to the Aftonian. It may be briefly summarized as follows:

1. On the opposite or west side of the same lobe of the ridge, and only a few rods away, there is a strong spring at a level only a little below that of the base of the manganese deposit. In this territory springs almost universally have their source in the Aftonian gravels, and these gravels are commonly associated with such silt as appears above and below the manganese deposit. Moreover it is very probable that the shallow well already noted, which is now partly filled, derives its water from the same stratum of Aftonian gravels immediately below the lower silt.

2. Manganese dioxide is widely distributed throughout the Aftonian sand and gravel beds in greater or lesser quantities, and has not in this region been detected in any other formation. Its abundance in this section is suggestive.

3. The thickness of the overlying loess, and the resemblance of its lower part to some of the Loveland joint clay would also suggest a comparatively great age for the manganese bed.

4. While the fossil shells from this stratum are somewhat unlike those which were collected in the Aftonian beds, the difference is no greater than that which we might expect in different parts of the same region, especially since here no doubt special conditions existed. It is probable that the deposit was formed in a swamp or shallow lake, and both its shores and bottom would produce environment unlike that of the Aftonian streams. The preponderance of terrestrial species is, however, very unusual. If this deposit proves to be Aftonian the list of Aftonian molluscan fossils will be increased by ten terrestrial and two aquatic species, as is shown by the comparative table. It should be noted that all these species live in Iowa today, and that one only, Helicina occulta, does not now live in the western part of the state, where it was formerly quite common, as is shown by the fossil shells in the two older loesses. 
KANSAN STA GE.

The Kansan drift is well developed in the uplands of both Harrison and Monona counties, but is usually deeply buried under the loess. For that reason few exposures appear excepting in the bluffs of the Missouri and its larger tributaries.

This drift consists in the main of a light ashen blue joint clay, which is more or less clouded and streaked with calcium carbonate, in which the western Kansan is especially rich, and contains pebbles and bowlders among which larger bowlders of Sioux quartzite are common. While the greater part of this formation in the western part of the state (and in our territory) contains chiefly pebbles and small bowlders, occasionally very large bowlders of granite and Sioux quartzite are found, especially along the Missouri and Little Sioux bluffs in the northern part of Monona county.

When present the Kansan rests directly on Aftonian, being very sharply separated from it by usually oxidized lines, as in figure 1, plate XXVIII, or calcareous nodular plates, as shown in figure 2, plate XXVII, and figure 2, plate XXVIII. With its associated Loveland it uniformly lies below the bluish gray postKansan loess, and when the Loveland is not developed the drift is separated from the loess by a more or less distinct ferretto zone.

That this is Kansan drift is shown by its stratigraphical position between the Aftonian and the post-Kansan loess, and by its composition, which shows the ordinary blue joint clay with dark colored pebbles and bowlders predominating. It is also frequently stained with iron, especially along lines of fracture and old roots.

It differs from the Kansan of the eastern part of the state in the relatively larger amount of calcium carbonate, which usually whitens the lines of fracture and the faces of the little blocks of joint clay and covers the pebbles and small bowlders to such an extent that it sometimes gives a chalky appearance to the exposure, and large calcareous nodules are not uncommon. It also differs in the more frequent occurrence of Sioux quartzite bowlders. 
It differs from the Nebraskan drift in its lighter color, more abundant bowlders (including Sioux quartzite) and calcium. carbonate, and in its coarser fracture.

It varies in thickness up to twenty feet in the exposures, but well-borings indicate that it probably reaches a thickness of at least $100^{\circ}$ feet.

Its lyypsometric distribution is quite variable. In the interior of the upland regions it is usually so deeply buried under loess and Loveland that but few exposures appear, and wells furnish. the chief source of information. Unfortunately well-diggers do not as a rule discriminate between the several members of this series, and the records are not therefore always satisfactory.

The loess covering thins out eastward, however, and brings the Kansan and Loveland much nearer to the surface. This is especially true of the southeastern part of our area. Thus at various points in Washington township, Harrison county, cuts in the road, especially on the lower slopes of bills, display typical Kansan. Such cuts may be seen on the section line between sections 30 and 31,5 and 6 , and 6 and 7 , and in the southeast quarter of section 17, all in township 78 north, range 41 west. Here the overlying Loveland and loesses are thin, each usually not exceeding five or six feet in thickness, especially on the slopes, the contours of whicl the loesses follow approximately, usually thickening toward the top of the ridge.

Northward and westward the superimposed deposits are thicker, and the drift is exposed only along the lower slopes in the deeper ravines and valleys of the rough areas already noted, or along the bases of the bluffs of the larger streams. Illustrations of the former may be seen in the wagon-road in the southeast quarter of section 11, township 78 north, range 43 west, and on the north line of the same section, and above the Hull sandpit in the northwest quarter of section 3 of the same township; and the latter, which are much more common, may be found at the bases of many of the bluffs bordering the valleys of the larger tributaries, as well as along the bluffs of the great valley. Examples of Kansan exposures along the larger tributaries in Harrison county may be seen at the following points: at and near the Cox pit on the east side of the Boyer; along the Willow in the 
north half of section 7, and the east half of section 6 , township 80 north, range 42 west; and along the Soldier in the northeast quarter of section 6 , township 80 north, range 44 west, near the northeast corner of section 13, township 81 north, range 44 west, and in the Peyton pit. Along the Missouri and Little Sioux bluffs the chief exposures of Kansan are located at the following points: at the McGavern pit; in Missouri Valley at the Charles Smith brickyard, and on the south side of the entrance to Snyders Hollow; at the Robinson and Wallace pits; and at the Murray hill and county line exposures.

The section in the Charles Smith brickyard shows the following :

5. Yellow loess, 90 feet.

4. Blue-gray loess (post-Kansan) about 2 feet exposed but apparently about 10 feet thick.

3. Loveland, 2 to 7 feet.

2. Kansan, 10 to 12 feet exposed, but reported by Mr. Smith as about 90 feet in thickness as determined by boring.

1. Sand, reported by Mr. Smith.

The Loveland becomes thicker southward near the schoolhouse.

The section at the entrance to Snyders Hollow is as follows:

3. Blue-gray loess (post-Kansan), exposed 6 feet.

2. Loveland, slightly pebbly below, 2 to 3 feet.

1. Kansan, exposed to 20 feet above the valley, but obscured below by a talus.

The remaining sections have already been described in connection with the Aftonian.

Northward the elevation above the alluvial plain reached by the Kansan drift increases, being fully 120 feet at Murray hill,* and the total elevation of the uplands becomes correspondingly greater.

In Monona county the loess is also thinner in the eastern part and thickens towards the bluffs and, as in the northern part of Harrison county, the Kansan drift rises to a height of probably not less than 100 feet above the Missouri valley and makes up a large part of the bulk of the uplands, which are everywhere

- It is probable that the Kansan mass was abnormally pushed upward here by the ice which plowed the Aftonian, but the Kansan is normally higher in the northern part of the county. 
topped with loess. In the bluffs facing the Missouri valley north and west of Grant Center, and also in those extending for some distance to the northeast on the west side of the Little Sioux, the Kansan is exposed to a height of not less than eighty feet above the valley and forms an imperfect bench, or gentler lower slope, similar to that formed by the Aftonian and Kansan on Murray hill (see plate XXIX, figure 1). This bench or slope is usually conspicuously strewn with large bowlders of granite and Sioux quartzite, and Aftonian sand and gravel frequently appear in its basal part. Near the line between sections 12 and 13, township 85 north, range 44 west, northwest of Mapleton, Kansan drift may also be seen in the road ascending a steep hill rising to a height of more than eighty feet above the Maple valley.

The best inland exposures of Kansan in the northeastern part of Monona county are those in the McCleary pit, the Pinckney pit, the slope near the Griffin well, and the Ferdig pit, which have been noter in connection with the discussion of the Aftonian.

The most conspicuous exposures which were noticed along the larger tributaries were the following:

A series of small exposures along the wagon-road between Turin and Castana, and extending beyond Castana, on the west side of the Maple valley; the Ordway pit which presented eighteen feet of typical Kansan till; the Hawthorn pits northwest of Mapleton; the Woodwards Glen section on the west side of the Little Sioux valley, and the Aldrich and Young pit and the pit in section 12, townsliip 85 north, range 44 west, on the east side of the same valley.

Exposures of Kansan in the bluffs facing the great valley were oloserved at the following points in Monona county: A series of irregular sections at least fifteen in number appearing just above the wagon-road at the foot of the bluffs and extending across Sioux township; the Elliott pit at Turin; the Weniger pit; and the sand-pits in sections 7 and 30, township 85 north, range 44 west, already described, and various exposures lying between them. All the sections specifically named have been described under the Aftonian. 
In all cases the Kansan till in the sections is typical, and is sharply separated from the underlying Aftonian by an oxidized line or band, or a layer of calcareous nodular plates, as described in the discussion of the Aftonian. Where the Kansan ice plowed the underlying strata Aftonian sand-bowlders and less frequently Nebraskan joint-clay bowlders are found in the lower part of the Kansan, and the line between the Aftonian and Kansan is then usually very irregular as in the McGavern pit, Murray hill section, the Ferdig pit, etc.

\section{THE LOVELAND.}

The name Loveland was proposed by the writer* for a formation consisting of heavy clay resembling somewhat the drift joint-clays. It was named from Loveland, a station on the Chicago and Northwestern railway Jocated a short distance south of the Harrison county line, where the type section well displays the formation.

The Loveland is usually associated with the Kansan drift, and where both are present the former invariably rests upon the latter, the line between them usually being quite sharp, though sometimes the Loveland becomes somewhat pebbly below and blends with the Kansan through a mixed stratum which seldom exceeds three or four inches in thickness.

The Loveland has evidently usually been confused with loess which it somewhat resembles, but as early as 1880 Aughey $†$ recognized it as distinct, and later Udden $\ddagger$ discussed it under the name "Gumbo or. Red Clay." It is a heavy, compact, reddish (especially on exposure to the air) or sometimes yellowish silt which when dry is hard with a tendency to break into blocks like a joint clay, and when wet becomes very tough and sticky and hence is sometimes called a gumbo.

It is usually homogeneous, consisting of fine materials, but quite frèquently coarse grains of sand and small pebbles are scattered through its lower portions, these sometimes being so abundant that they cause a blending of this formation with the underlying Kansan. Sometimes the Loveland appears to be

*Bull. Geol, Soc. of America, Vol. 20, p. 405, 1910, foot-note. See also Science, N. S., Vol. XXXI, pp. $75-76,1910$.

The Physical Geography and Geology of Nebraska, pp. 260-261

tGeology of Pottawattamie County. Rep. Iowa Geol. Survey, Vol Xr, 1901, pp. $255-256$. 
quite homogeneous and unstratified, but usually it shows more or less distinct horizontal lamination and stratification,* and sometimes contains interlaminated thin layers of sand, the whole evidently being a water deposit. On the Nebraska side of the Missouri river above Florence such a stratified bed of Loveland also contains a layer of volcanic ashes varying from two to fifteen inches in thickness.

The Loveland is usually quite calcareous, and frequently contains lines or layers of very large calcareous concretions not infrequently three to six inches in diameter and six to twelve inches in length. These are sometimes in the uppermost part of the Loveland or at the very base of the overlying loess as though the solution from which they were developed had been arrested in its downward course by the much less pervious Loveland. Less frequently distinct lines of similar nodules are found within the Loveland or at its very base. The bands of nodules within the body of the Loveland follow the lines of stratification or lamination and probably occupy more porous layers through which the calcareous solution penetrated laterally. Scattered nodules are very.infrequent in the Loveland.

The line of demarkation between the Loveland and the loess is usually very sharp, as in the upper part of the Murray hill exposure, the section at the entrance to Snyders Hollow, and in the great majority of sections observed in this territory and elsewhere, but in two sections, one at the point marked $x$ in plate XXXI, figure 2, and the other north of Florence, Nebraska, there seems to be a blending of the two formations which is probably due to local rain-wash at the time that the loess commenced to form on the old plant-covered Loveland surface. In both of the sections mentioned loess shells, more or less broken, are found in the transition portion, but nowhere in the several hundred sections examined in Iowa, Nebraska, Kansas and Missouri, where the formation is best developed, or in the states where it is less prominent, has any trace of fossils been observed in typical Loveland.

- This lamination however is not like that of the loess, but is regular and the lines are continuous as in typical water-lamination. 
In thickness the Loveland is very variable, reaching fully forty feet in the Council Bluffs and Omaha area where it is best developed, but in the Harrison and Monona county sections the maximum exposure observed does not exceed twenty feet.

In vertical distribution the Loveland is very irregular. Some, times it rises to a height of fully 180 feet above the valley, as on Murray hill, or it may be found near the very base of the bluffs as at the Third Ward schoolhouse in Missouri Valley, in the exposure east of Pisgah, and at many other points. Not infrequently the section of a ridge shows the Loveland to be the thickest in the highest portion of the ridge with its thinner edges extending down over the slopes of the Kansan core, the whole mass thus roughly following the vertical contour of the loess-covered ridge.

This irregularity in the vertical distribution of the Loveland, which is elearly a water-deposit, suggests that it was formed during the melting of the Kansan ice when silt was carried into icebound basins, these being located at first on the higher ridges where the thinner ice was the first to melt, and when the ice finally disappeared these masses of silt, often lens-shaped, were spread upon the underlying Kansan drift, the entire process being carried on in the manner described by McGee.*

In short the explanation of the genesis of the Loveland is probably to be found in that which McGee suggested for the loess in the classic cited. +

The total absence of fossils from true Loveland further strengthens the conclusion that it was formed under the conditions stated, and removes one of the most serious objections which could be made to the application of the explanation to the genesis of the fossiliferous loess.

In age the Loveland evidently corresponds roughly to the Buchanan gravels, $\neq$ but was probably formed somewhat earlier, before strong currents were developed, or in places where such currents did not occur.

*11th An. Report U. S. Geol. Survey, Vol. XI, part I, 1891, pp. 567-577.

+It is evident that McGee did not distinguish between the Loveland and the loess.

For a discussion of the Buchanan see Professor Calvin's report in Iowa GeolSur., Vol. VIII, 1898, pp. 241-244. 
The Loveland may be distinguished from the loess by its reddish color, by its greater hardness or toughness, this being so striking that the hoe will usually reveal the difference even in the dark, by the absence of characteristic horizontal loess cleavage and the tendency to break up in the manner of joint clay, by the distinct water-lamination witl the occasional inter-lamination of sand, by the presence of sand and pebbles in the lower part, and by the total absence of fossils. Moreover its position with reference to the Kansan and loess is uniformly consistent and the line of demarkation between it and the loess is almost invariably sharp. When the Kansan is absent, as in the Peckenpaugh section, the Loveland still holds a consistent position with reference to other formations. The manner in which the Kansan sometimes runs out, permitting the Loveland to rest directly upon the Aftonian is illustrated in the Pinckney pit, figure 29.

The Loveland is as widely distributed as the Kansan drift, but it seems to have reached its maximum development in the Missouri valley. In Harrison and Monona counties it is present in nearly all the sections showing Kansan drift, and in a number of cases it appears where the Kansan is missing or buried from sight. Some of the Loveland exposures have already been noted in connection with the Aftonian sections, as for example in the County-line exposure, the Wallace pit, the Peckenpaugl section, above the Cox pit and in the Murray hill section in Harrison county, and in the Elliott pit, the Ordway pit, the Hawthorn pit, the Pinckney pit and the Ferdig pit in Monona county. The Washington township sections, the Smith section and the Snyders Hollow sections, described in connection witl the Kansan sections of Harrison county, also show typical Loveland. Other exposures were observed at the following points:

In Harrison county, at several points near the base of the Boyer valley bluffs in sections 11 and 12 , township 78 north, range 44 west, along the road at the foot of the hill near the southwest corner of section 35 , township 80 north, range 43 west, along the bluffs of the main valley in the east half of section 27 , the southeast quarter of section 21 , and the southeast quarter and the northeast quarter of section 16, all in township 80 north, range 44 west, and near the foot of the bill east of Pisgah; and 
in Monona county in numerous exposures along the bluffs in Sioux township (one of the best being just east of the intersection of the roads in the east half of section 21, where the Loveland reaches to an altitude fully eighty feet above the valley), near the south line of section 34 and in the northwest quarter of section 27 in township 83 north, range 44 west, along the Maple valley bluffs in the northeast quarter of section 7 , the northwest quarter of section 9 , and the southeast quarter of section 17 , in township 84 nortl, range 44 west, and in the west half of section 12, township 85 north, range 43 west, where the Loveland is at least twenty feet thick and reaches an altitude of over 100 feet above the Maple valley.

As noted, the Loveland rests directly on Kansan drift when the latter is present; its upper contact is uniformly with the bluish gray post-Kansan loess when that member is present, as in several of the Washington township sections near Persia, in the section at the entrance to Snyders Hollow, in the exposures in sections 3,10 and 15 in Sioux township, Monona county, and elsewhere. When the post-Kansan loess is present the line between it and the Loveland is very sharp and the difference is frequently made still more prominent by a ferruginous line. When the post-Kansan loess is absent the lower yellow loess rests on the Loveland and the difference is then less marked because of greater similarity in color, though the line of demarkation is usually sharp, as in the Murray hill section.

The Loveland is deemed worthy of a special name because it is a distinct, wide-spread formation, evidently developed undercircumstances which were wholly unlike either typical glacial or interglacial conditions, and because it is convenient to have a name by which it may be designated in connection with discussions of the apparently similar loess.

It does not often reach the surface excepting in narrow belts on hillsides, but where it does so it is lighly valued, being especially adapted, according to $\mathrm{Mr}$. J. B. P. Day, who has had extensive experience, to the growth of fruit-trees, probably because of its ability to retain moisture. 
THE LOES.S.

The uppermost member of the upland Pleistocene series consists of the loess, or more properly the loesses, for there are certainly two and possibly three within the limits of our territory.

The writer has already pointed out* that in the Missouri valley there are several loesses, that some are interglacial, some postglacial.

Various formations, such as alluvium, Loveland joint-clay, drift and Aftonian silt have been confused with the loess, and these various deposits were supposed to represent different phases of the loess formation, but probably the first recognition of two distinct loesses was made by Pratt at Davenport, Iowa, who described† two distinct loesses, clearly describing our postKansan loess as a "bluish-gray clay" (number 3) containing a few terrestrial shells, and the later loess as "yellow clay" (number 2), containing five species of terrestrial mollusks.

Later McGee $\ddagger$ recognized a lower light-blue loess, evidently post-Kansan, and Leverett distinguished a whitish or blue loess and a yellow loess in Illinois. $\$$

That at least some of the loess is inter-glacial was also observed by McGee and Call** at Des Moines, Iowa, where loess was found between what we now know as the Kansan and Wisconsin drifts, and by Leverett, $\uparrow+$ who found loess under the Wisconsin drift in Illinois.

The loesses agree in consisting of fine, fairly homogeneous material of which usually at least two-thirds are made up of quartz sand dust, and they were evidently formed under essentially the same conditions. They usually contain nodules of calcium carbonate $\ddagger$ which vary greatly in form and size, and they are frequently fossiliferous, the fossils being mollusks among which terrestrial species vastly predominate.

\footnotetext{
* Rulletin from the Laboratories of Natural History, State University of Iowa, vol. $\mathrm{V}, 1004$, pp. $352-368$

tProceedings of the Davenport Academy of Science, vol. I, p. 97, plate XXXII. 1876 It is interesting to note that his peat-bed (number 4), ancient soil (number 5 ) and prohably the member number 6 are evidently Aftonian. Number 6 may be partly or wholly Nebraskan.

$111 \mathrm{th}$ Annilal Report U. S. Genlogical Survey, nart I, p. 437, 1891.

8Monograph U. S. Geological Survey, vol. XXXVIII, 1899, pp. 125 and 127

* American Journal of Science and Arts, 3d series, vol. XXIV, 1882, pp. 202-223.

t广Loc. cit., pp. 187 and 188 .

It Similar nodules are found in the Loveland, the Kansan, etc. They are therefore not peculiar to the Ioess.
} 
They possess more or less distinct peculiarities of color, texture, lamination, distribution of ferric oxide, size and distribution of calcareous nodules and even to some extent in the distribution of the species of fossils, and these will be brought out more fully in connection with the discussion of the several loesses.

These loesses, being inter-glacial, are not of the same age, but in our territory they form a continuous series, the intermediate drifts being absent, and for this reason, and also because of the similarity of their genesis, they may be considered together. The oldest of these loesses was formed in the interval following the Kansan; all the subsequent drifts failed to reach this region, but their influence extended to it more or less, producing new conditions which left their impress on the loess of each succeeding interval, that of the most remote Inlinoian being least evident.

The loesses are distributed generally but not uniformly over all the uplands; they are absent from the alluvial flats and frequently from the bases of the bluffs, as at $\mathrm{C}$ in figure 1 , plate XXIX. They form a more or less irregular veneer over the uplands, and are usually thickest at the tops of the more prominent ridges, the greater prominence of these ridges being due in large part to the accumulated loess.

The fact that the loess thus follows the vertical contours of the ridges has led to exaggerated estimates of its thickness, especially where this was based on observations made in shallow road-cuts and gullies extending from the base to the top of the ridge, the assumption then being made that the entire ridge consisted of loess.

The greatest total thickness of the loesses in our territory which the writer has been able to determine with reasonable certainty is about 100 feet. This measurement was made in the great cut which was excavated through the loess ridge at Smith's brickyard in Missouri Valley, where a deposit of ninety feet of yellow loess was found resting on bluish gray post-Kansan loess of which only about one foot was exposed but which, according to Mr. Charles Smith, who operates the brickyard and who has made sections and horings, is not to exceed ten feet in thickness, thus making a total of about 100 feet. 
On the opposite or west side of the Missouri river and along: the entire eastern border of Nebraska the writer has been unable after several years' search to find a single point at which the aggregate thickness of the loesses exceeds thirty-five feet. Nor has he found any point thus far anywhere within the loess territory at which the thickness of the loess certainly exceeds 100 feet. It is possible, indeed probable, that on some of the highest ridges on the east side of the Missouri river the loess does exceed this thickness, but so far as the writer knows no authentic measurements have demonstrated this. The estimates of greater thickness which have been hitherto published were either based on the erroneous assumption that the underlying formations are horizontal and that a hill covered with loess from base to summit is made up wholly of loess, or they included the Loveland joint clay with the loess.

The lowest member of the loess series, designated as the postKansan loess, is usually readily distinguished by its bluish gray color, usually varied by ferruginous stains, lines or very prominent root-tubes, and it is sharply set off from the upper loess, the line of demarkation frequently being made very conspicuous by a ferruginous line or band.

The upper members of the series blend more or less, usually intergrading very gradually, and for this reason, and because of their color, they will be referred to collectively as the yellow loess.

The discussion of the loess here presented is based on a more or less careful study of 208 sections in Harrison county and eighty-nine in Monona county. Many other sections were observed and examined casually, but they seemed to offer neither additional or contradictory evidence, and they are not here considered.

Fossils were found in ninety-three of the 208 sections in Harrison county, and thirty-two of the eighty-nine sections in Monona county. Larger sections or closer search would probably reveal fossils in many of the deposits in which none were observed, but there are undoubtedly large areas, especially on the interior prairie uplands, where no fossils are found in the loess because no mollusks live in such places. 
In all cases in our territory where sections show the bluish post-Kansan loess, the yellow loess also appears in the same section or on the slopes. immediately above it.

In three such sections in Harrison county and one in Monona county fossils were found in both the bluish and the yellow loesses; in thirteen sections in Harrison county and two sections in Monona county fossils were found only in the bluish loess; and in one case only, in Harrison county, they were found only in the upper or yellow loess. No fossils were found in either b]ue or yellow loess in twenty-four sections in Harrison county and thirteen sections in Monona county.

Of the sections in which yellow loess only appeared ninetythree in Harrison county and twenty-nine in Monona county were fossiliferous, while no fossils were found in seventy-four sections in Harrison county and forty-five in Monona county.

The fossils are considered more fully in connection with the discussion of the genesis of the loess.

\section{Bluish Loess (Post-Kansan)}

The post-Kansan Joess is the oldest of the loesses, and in our territory it does not, so far as observed, exceed fifteen feet in thickness. It is probably a remnant in large part of a deposit which was formerly much larger, for its upper surface frequently presents evidence of weathering and erosion, and it is often unconformable with the loess above.

As already noted the post-Kansan loess is usually light bluish gray in color, more or less varied with ferruginous cloudings, streaks, bands, and especially root-tubules. The stains and bands are more frequent in the upper part and in the sections they appear at or near the line of contact with the upper loess. The root-tubules usually form a very conspicuous feature of this loess, being often very numerous and reaching a diameter of two inches or even more. They follow a more or less vertical course, this being determined by the direction of the roots whose decay left channels through which the iron oxide entered from above. That the sesquioxide of iron $\left(\mathrm{Fe}_{2} \mathrm{O}_{3}\right)$ which produces the ferruginous colors did come from the upper loess is suggested by its usual presence in the form of bands and lines in the upper part of this loess; by the fact that it does so follow old 
roots, remnants of some of which have been found in the tubules of this loess, while in the lower part of the upper loess similar tubules have been found even on living roots;:. and by the further fact that the lower part of the superimposed yellow loess is frequently partly leached of its iron, leaving the leached portions (which seem to follow roots or crevices) bluish gray and not unlike the body of the post-Kansan loess in appearance. $\dagger$

This might suggest that the bluish gray color of the postKansan loess was due to a similar leaching, but it is quite probable that the color is determined by the source of the material in the bluish Kansan till and silts which contributed to the formation of river-bars during the deposition of this loess.

In texture this loess is very fine and compact, when moist resembling putty, and because of its closer grain it takes up moisture more slowly but retains it better than the yellow loess. For this reason, where exposures of this loess appear at the surface, they are frequently covered with a vigorous vegetation, while the more porous yellow loess is bare, or its vegetation is suffering.

Calcareous nodules may or may not be present. When present they are usually less abundant than those in the upper yellow loess, and are generally smooth and rounded, though small irregular nodules also appear.

The presence of iron root-tubules and calcareous nodules has but little significance however, as both are found in other formations, and both have been observed on living roots. Being formed from solutions which may be carried upward or downward in these formations they are of little value in determining the identity or age of the loess.

The post-Kansan loess frequently shows very fine but dislinct lamination parallel to the contour of the upper surface. Even where this lamination does not appear on the surface of the section the loess will break readily along corresponding planes thus indicating that even the apparently homogeneous portions are really laminated.

\footnotetext{
* In a cut west of Logan, in the southeast quarter of section 12 , township 79 north, range 43 west, such tubules were found in the lower part of the yellow loess on the roots of an old bur-oak.

tFor further reference to this leachirg nnin in an illustration of the ferruginous and leached tubules, see the writer"s parer on "The Genesis of Loess a Problem in Plant Ecolngy", in the Proceedings of the Iowa Academy of Science, vol. XV, 1909, 'p. 63 , plate VII, figures 1 and 2 . (The latter is reproduced in figure 31 .)
} 
The post-Kansan loess is frequently fossiliferous. Of the forty-one sections examined in Harrison county sixteen yielded fossils, and of the fifteen examined in Monona county three were fossiliferous. In other portions of the state, however, the number of fossil-bearing sections is relatively larger. The distribution and relative abundance of the species of fossil mollusks occurring in this loess will be discussed on succeeding pages. It may be stated, however, that the fossils furnish no safe criterion by which we might distinguish between the several loesses. Those in the post-Kansan loess are usually softer and more fragile, probably because of greater age and because they have been imbedded in a formation which more readily retains water. There is, however, no material difference between the species of this . and the upper loesses.

That this loess belongs to the interglacial period immediately following the Kansan is shown by the following two significant facts :

1. Throughout the territory of wide extent in which it occurs it invariably rests upon the Kansan or Loveland, or where these are not present, on the next older member of our series which is present. No formation intervening between the KansanLoveland and this loess has been found.

2. In one instance in Muscatine the writer found a bed of fossiliferous bluish gray Kansan loess, in all respects like our post-Kansan loess, between the Kansan and Illinoian drifts." Some of the buried "silts" described by Leverett $\dagger$ may prove to be the same. $\neq$

The post-Kansan loess seems to be quite generally distributed in the uplands of Harrison and Monona counties, but it is more frequently brought to light in road-cuts and other sections in the eastern and southeastern part of the territory east of the region of the high bluffs, because it is much nearer the surface, the superimposed yellow loess being quite thin. In such sections the bluish gray loess is usually better displayed on the lower slopes of the hills, usually tapering out or disappearing under the heavier upper yellow loess towards the summits of the ridges.

\footnotetext{
* See Proceedings of the Iowa Academy of Sciences, vol, XIV, 1908, pp. 239-240, plate $\mathrm{I}$, figure 2 .

Thace cit., pp. 114-116.

tOthers are probably Aftonian silts.
} 
POST-KANSAN LOESS SECTIONS IN HARRISON COUNTY.

Such sections were observed in Harrison county at the following points :

1. A road-cut on the north line of the northeast quarter of section 12 , township 78 north, range 41 west, showing the following section:

Yellow loess, 5 to 6 feet.

Bluish loess, with iron root-tubules and fossils, laminated, 4 to 5 feet.

2. A road-cut on the north line of the northwest quarter of the same section, showing the following:

Yellow loess, 5 to 6 leet.

Ferruginous line.

Bluish loess with iron tubules, 1 foot.

3. A road-cut on the north line of the northeast quarter of section 36 , in the same township, gives

Yellow loess, 4 to 5 feet.

Ferruginous band, narrow.

Bluish loess, with calcareous nodules, iron tubules, and shells, 6 feet. Contained a few Lymnæas which were arranged in a nearly horizontal line or band as if deposited on. the edge of a pond.

4. A road-cut in the southwest (]uarter of section 19, townslip 78 north, range 43 west, in which is exposed

Yellow loess, 2 to 4 feet.

Bluish loess, with ferruginous streaks and a few very fragile land shells.

5. A road-cut at foot of hill in the southeast quarter of section 28 , township 78 north, range 43 west, shows

Yellow loess, 6 feet.

Ferruginous band, 1 inch.

Bluish loess, typical.

6. In a road-cut near foot of slope, in the southeast quarter of section 23, township 78 north, range 43 west, is seen

Yellow loess, 6 to 7 feet.

Ferruginous band, 4 to 6 inches.

Bluish loess, with iron tubules and small calcareous nodules, 3 feet.

Similar sections were observed on the north line of section 30 , in the southwest quarter of section 28 , and in the sontheast quarter of section 23, township 78 north, range 43 west; and on the south line of the southeast quarter of section 8 , and the north line of section 7 , township 78 north, range 41 west. 
In the northern part of the county, northeast of Pisgah, several similar sections were observed in like situations. The following sections will serve as types.

7. A road-cut on the south line of the southwest quarter of section 6 , township 81 north, range 43 west.

Yellow loess, 5 feet.

Bluish loess, with iron tubules, 3 to 4 feet.

8. A road-cut located at the southeast corner of the same section.

Yellow loess, thin and irregular.

Bluish loess, with iron tubules (more abundant below) and fragments of fossils, nearly 10 feet.

Other similar sections in this area are located as follows: In the northwest quarter of section 12, township 81 north, range 44 west, and several 'uts in the northeast quarter' of section 7, township 81 uorth, range 43 west.

Sections of the same character were also seen in the rough, inland, timbered areas in the eastern part of Harrison county. 'Thus a section on the south side of the northwest quarter of section 35 , township 80 north, range 42 west, showed the following:

Yellow loess, 6 feet.

Bluish loess, with iron tubules, less than 1 foot.

Other sections in the same kind of territory are located on the east side of the southwest quarter of the northeast quarter of section 31, township 80 north, range 41 west, and on the north line of the northwest quarter of section 11 , and the north line of section 10, in township 78 north, range 43 west.

In the rough territory west of Logan and in the vicinity of Magnolia the post-Kansan loess also frequently appears in rather shallow cuts, and this quite frequently at rather high altitudes. Some of these sections are located as follows:

9. A road-cut in the southeast quarter of section 12, township 79 north, range 43 west.

Brownish loess and soil, 1 to 4 feet.

Yellow loess streaked with bluish, 5 feet.

Bluish loess (post-Kansan), 1 to 2 feet.

10. A road-cut in the southeast quarter of section 6 , township 79 north, range 43 west. (See figure 30 .) 
Yellow, slightly reddish loess (A), 4 feet.

Bluish post-Kansan loess, more or less streaked and stained with iron (B), 4 feet.

Bluish gray post-Kansan with large iron tubules, 2 feet.

11. A road-cut near the southwest corner of section 8, township 79 north, range 43 west, southwest of Magnolia.

Yellow loess, fossils in lower part, 7 to 9 feet.

Bluish post-Kansan loess, laminated, with large iron tubules, especially below, with fossils, 5 feet exposed.

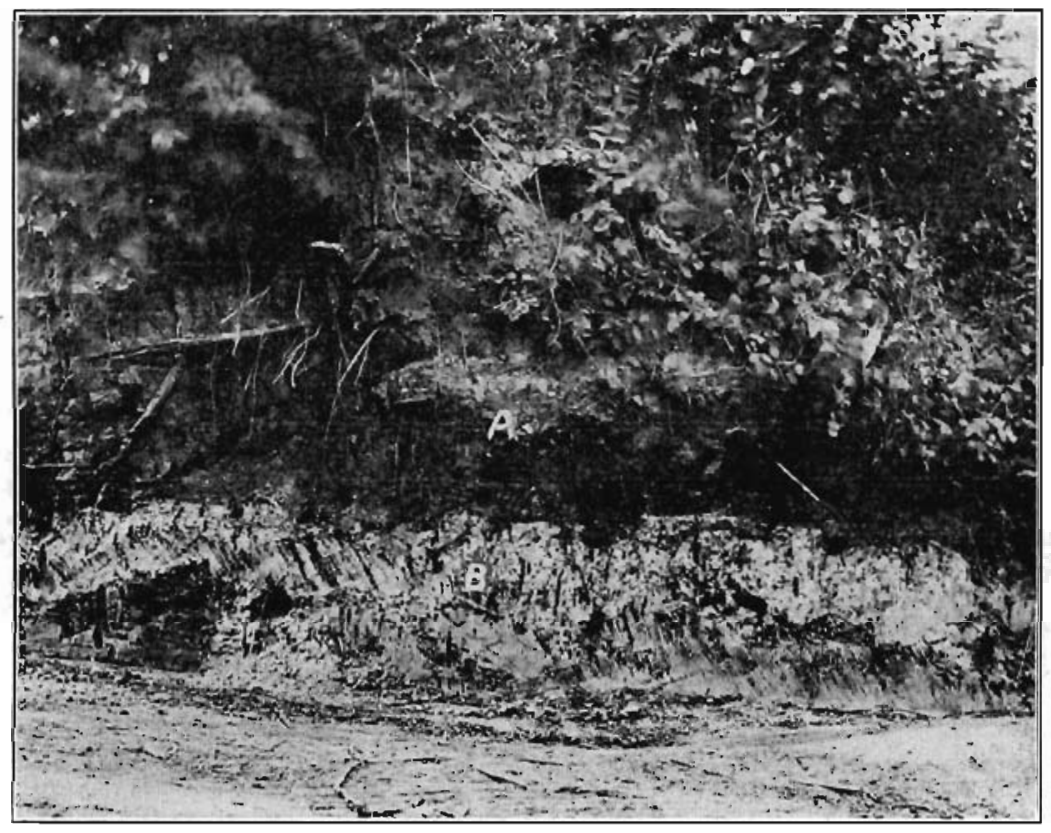

Figure 30. Two loesses, southeast quarter section 6 , township 79 north, range 43 west.

(A) Upper yellow loess. (B) Lower post-Kansan loess. Its upper part marked

$\mathrm{B}$, is stained and streaked with iron (see $\mathrm{p}$. is:3),

The bluish loess here nearly follows the vertical contour of the hill, but disappears under the heavier yellow loess near the summit.

12. A road-cut twelve to fifteen feet deep south of the northwest corner of section 8 , township 79 north, range 43 west, shows bluish loess, especially on lower part of the slope, with yellow loess above. The blue loess is laminated, and contains fossils, large iron-tubules and some nodules.

Other sections in this area are located as follow. In the west half of section 33, and the southeast quarter of section 31 , 
township 80 north, range 43 west; on the east line of the southeast quarter of section 7 , township 79 north, range 43 west; and in the northwest quarter of section 1, township 79 north, range 44 west,

Along the bluffs of the Missouri valley post-Kansan loess is exposed at a number of points. The sections in the Smith brickyard and at the entrance to Snyders Hollow at Missouri Varley have been given in connection with the discussion of the Kansan drift.

Other sections showing post-Kansan loess are located as follows:

In the southeast quarter of section 17 , and in section 20 , township 81 north, range 44 west; and in a road-cut just north of Calhoun. The last section is here presented in detail:

13. A road-cut on hill just north of Calhoun. The post-Kansan loess here extends for some distance up the slope along the road and almost parallel to the surface.

Yellow loess, with numerous calcareous nodules and some fossils, 3 feet.

Brownish yellow loess, with fossils, 2 feet.

Bluish (post-Kansan) loess, with fossils and iron tubes, 3 feet exposed, but thicker near the foot of the hill.

In some cases post-Kansan loess is exposed along the valleys of the larger tributaries of the Missouri. The following sections were observed along the Boyer valley:

14. An exposire in the southeast quarter of section 11, township 78 north, range 44 west.

Yellow loess, 6 to $s$ reet.

Ferruginous line.

Bluish post-Kansan loess, less than 1 foot exposed.

An exposure in the northwest quarter of section 31, township 81 north, range 41 west, and a street eut in Logan one-half a block nortl and one block west of the Chicago \& Northwestern railway depot, also show post-Kansan loess.

Similar exposures in the Willow valley in the north half of section 7, township 80 north, range 42 west, and in the Soldier valley in the 'northwest quarter of section 3, township 80 north, range 44 west, also show the post-Kansan bluish loess. 
POST-KANSAN LOESS IN MONONA COUNTY.

The post-Kansan loess of Monona county is in all respects like that of Harrison county and is found in similar situations.

Inland sections were observed less frequently than in Harrison county. The following section is the best one observed in the eastern rolling prairie regions.

15. A road cut on the line between sections 33 and 34 , township 85 north, range 42 west, in which the bluish loess may be seen in the lower two-thirds of the slope. It presents the following section:

Yellow or reddish Ioess 2 feet, becoming thicker near the top of the hill. Bluish loess (post-Kansan); with iron tubules, 2 feet exposed.

Another inland exposure of typical post-Kansan loess was observed in a gully, in the rough timbered area near the southwest corner of section 16, township 83 north, range 42 west.

A series of exposures of this loess was also found along the Missouri bluffs in Sioux township (township 82 north, range 44 west), located as follows:

.16. A road-cut near the middle of section 15 , showing the following section:

Yellow loess, rising above the section.

Bluish loess, with iron tubules, 12 feet.

Kansan drift, its upper surface 105 feet above the valley.

17. A road-cut in the southwest quarter of section 10, exhibits Loveland at the base, with fossiliferous bluish post-Kansan loess resting on it, and above this a compact yellow loess the lower part of which is also fossiliferous.

Two sections in the northwest quarter of section 10 also show bluish loess which is fossiliferous, and seven sections in the west half of section 3 expose blue-gray loess in which no fossils have been found.

Exposures of this loess were also observed in Grant township (township 85 north, range 44 west). One of these is located in the northeast quarter of section 19 at an altitude of 80 feet above the valley, and several are found in the southwest quarter of section 7 in a similar position. 


\section{The Yellow Loess}

The yellow loess is the most conspicuous member of the Pleistocene series in the counties here discussed. It determines the extreme features of the bluff topography, being thickest on the highest ridges, and forms the immediate subsoil over all the upland region.

As already noted it consists of two members which are more or less distinct in their extreme phases but which blend to such an extent that a clear separation is impossible. The maximum aggregate thickness of these yellow loesses so far as observed is

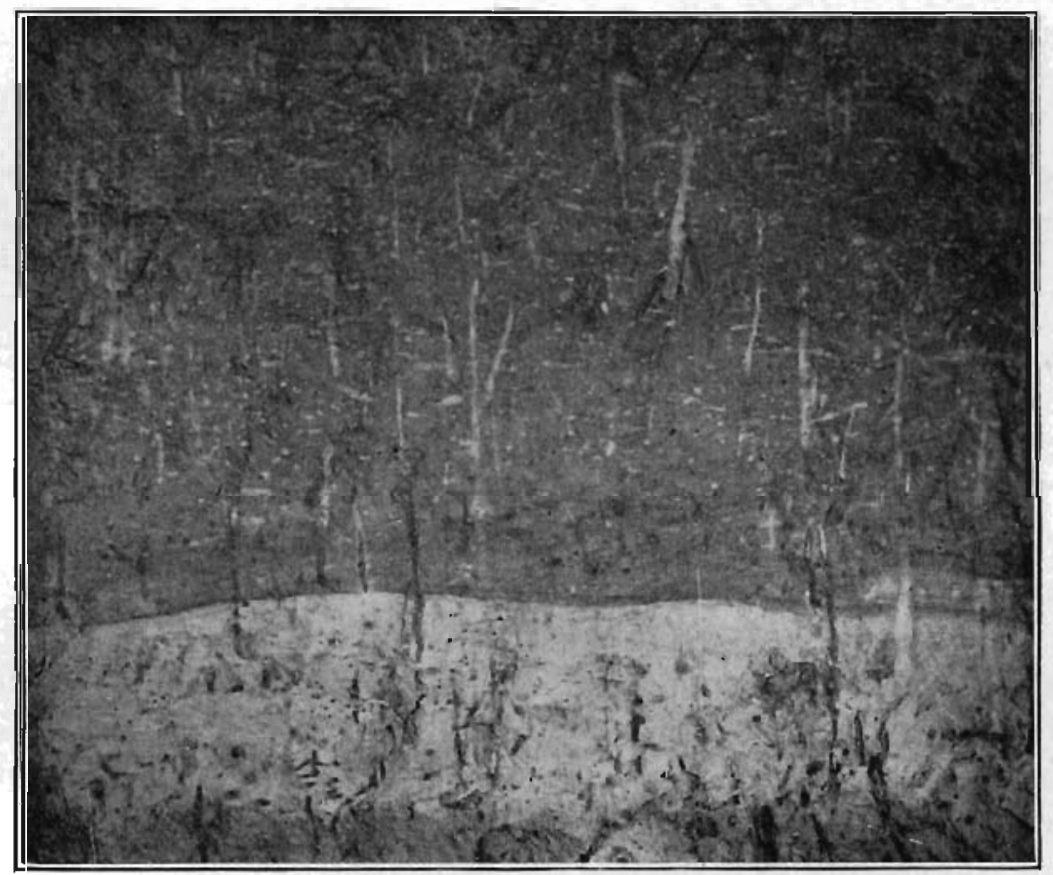

Figure 31. Section in Gaulocher's brickyard in Iowa City, Iowa, showing two loesses very sharply separated but with scarcely a trace of an oxidized line between them. The lower is a gray post-Kansan loess with iron tubules. Tlie upper yellow loess has gray vertical lines or streaks which resemble the lower loess, and which were evidently formed by the roots. In some cases the gray upper streak is continuous with the iron tube in the lower loess; both having evidently been formed by the same root long after both loesses were formed. (See p. 388.)

about ninety feet (see record of the Smith brickyard section at Missouri Valley), and they are very much thicker along the bluffs of the Missouri valley and the abrupt bluffs of the large tributaries than they are farther inland. 
The lower yellow loess is compact, usually laminated, especially in its lower part, and when dry it breaks vertically into irregular columns. While the prevailing color is yellow, and sometimes uniform, usually the lower part shows lines and small irregular areas of bluish gray, evidently formed br leaching along rootlets and crevices, somewhat in the manner suggested by figure 31 on a larger scale. These bluish lines are also sometimes parallel with the laminations, and it is probable that the lines and irregular streaks of bluish gray were formed long after the deposition of the loess. This portion of the loess is also streaked with sesquioxide of iron, the streaks and cloudings probably consisting of material leached from the bluish gray portions just described.

This loess contains scattered, commonly rounded and smooth calcareous nodules which usually vary from one-half to two inches in diameter, but are occasionally much larger, especially in the lowest part of the deposit. Where this loess comes to the surface, as is commonly the case on the inland areas, the uppermost three to five feet usually contains very numerous small and irregular calcareous nodules which prominently mark this part of the loess in nearly all the road-cuts and other sections.

The same portion of the loess is usually broken up into small irregular blocks (probably by the action of roots and frost) which separate readily when dry, causing the loess to crumble.

The lower yellow loess is usually quite fossiliferous, and fossils were collected in nearly one-half of the exposures examined. Not infrequently, especially in sections in the main bluffs, the lower part of this loess contains a more or less distinct band or belt, usually three to six feet in deptl, in which shells are very abundant, suggesting that during the deposition of this part of the loess the conditions were very favorable to snails (the surface probably being forest-covered) and that later, as the deposit piled up, the conditions became more and more xerophytic and consequently less suited to the majority of the species which form the loess fauna. The best illustration of the shell band was found in the Murray Hill exposure just above the Loveland, where it reaches a thickness of more than six feet, shading out upward. 
The upper yellow loess is lighter in both color and texture, and does not usually show distinet lamination. It is uniform in color and sometimes contains scattered calcareous nodules and a few shells, of which Succinea ovalis is the most common. Sometimes it shows an uppermost layer with numerous small irregular calcareous nodules and a tendency to crumble, such as is more clearly shown in the lower yellow loess where it comes to the surface.

In the accompanying table of fossils no attempt is made to separate the fossils of these two yellow loesses as the deposits blend almost imperceptibly and the fossils often grade upward gradually from the lower to the upper. The fauna of the upper loess is less rich in both individuals and species, however, and was evidently developed under xerophytic conditions not unlike those which prevail on the loess bluffs today, the few species being identical with those which occur sparingly on these surfaces at the present time.

The upper loess is practically restricted to the Missouri river bluffs and the more abrupt ridges and bluffs bordering the larger tributaries. It soon runs out inland, the lower loess there forming the surface. In a few places, as east of Murray Hill and north of Grant Center, where the sharp, billowy loess ridges extend farther inland, this loess forms their summits even at points quite remote from the bluffs. On the great river benches and on other inland surfaces the uppermost part of the yellow loess, forming an irregular inconspicuous veneer, also probably belongs to this member.

The difference between the two yellow loesses and the reason for their almost complete blending may be better understood by reference to the changes which have taken place in this part of the country since the Kansan ice period.

It is a well-known fact that Iowa geologists recognize three drift-sheets which followed the Kansan.*

The Kansan was followed by an interval in which the bluish gray loess was deposited, as has already been shown.

The Illinoian drift then entered the state, but was restricted to its southeastern part, practically the length of the state from

* For the distribution of the drift-sheets in Iowa see Calvin's map, plate III, in volume XIV of the Report of the Iowa Geological Survey (1904). 
Harrison and Monona counties. After another interval the Iowan followed, and though its western boundary has not been exactly determined, it is probable that it did not extend west of the center of the state; and lastly, succeeding another interval, the Wisconsin entered the state and extended westward to Carroll county, reaching a point but little more than the length of Crawford county from the northeast corner of Monona county.

It will thus be seen that none of these later drift-sheets reached our territory, yet it is reasonable to conclude that their proximity produced an effect upon the surface conditions even beyond their borders. There would perhaps follow first a destruction of the original flora and an exposure of the surface; the precipitation of moisture upon these surfaces would be affected; floods would originate in the glaciers and extend into the outlying regions; and finally when the glacier receded large quantities of new materials would be exposed to erosion and carried down the streams into the unglaciated territory, there to form bars from which the supply of loess-dust would be obtained.

The evidence now at hand indicates that during each of the interglacial intervals loess was deposited, and that at least a part of the yellow loess is interglacial. Thus at the point in the Wisconsin drift area which is nearest to our territory, namely in Carroll county, the first cut along the Chicago Great Western railway northeast of Carroll shows the following section near the middle of the south side:

6. Wisconsin drift, 1 to 5 feet.

5. Yellow loess (post-Iowan?), about 10 feet.

4. Bluish gray loess (post-Kansan), 5 to 6 feet.

3. Black, mucky, soil-like band, 1 foot.

2. Heavy, reddish, joint-clay (Loveland), 1 foot.

1. Kansan drift.

Both the loesses are fossiliferous, and they are separated by a strongly oxidized band four to ten inches wide. The lower is typical bluish gray post-Kansan, and the upper is the same as the lower yellow loess of Hairrison and Monona counties. It is therefore younger than the post-Kansan loess but older than the Wisconsin drift. 
But in the old quarry west of West Amana, Iowa, a similar fossiliferous yellow loess rests directly on the Iowan drift, the section showing the following members: ${ }^{*}$

4. Yellow loess, 10 feet, the lower 5 or 6 fossiliferous.

3. Iowan drift, 4 feet.

2. Kansan drift, 4 feet.

1. Carboniferous sandstone.

Here the loess is evidently younger than the Iowan drift, and it is probable that at least a part of the more compact lower yellow loess of Harrison and Monona counties is also post-Iowan. It is certainly younger than the post-Kansan loess, and it seems to be identical with a loess which in the Carroll section is clearly below the Wisconsin. It therefore represents the accumulations of one or both of the intervals following the Illinoian and Iowan drift periods. The fact that it is comparatively uniform suggests that it was formed chiefly or wholly within one of these intervals, and since loess essentially like it in Johnson and Iowa counties is post-Iowan, it is probably also post-Iowan. Certainly no variation in this loess which might have been due to two glacial periods has been observed.

The upper light yellow loess appears to be comparatively modern. It is found only in close proximity to the Missouri river, and forms the culminating features of the "snow-drift" topography which characterizes the Missouri bluffs region. It has probably been swept up from the great valley since the Wisconsin period and is evidently being formed very slowly today from the clouds of dust which are carried up by winds from the bars of the Missouri river during the drier seasons of the year.

While the upper loess usually blends with the lower, in' some places, as in the east half of section 22, township 82 north, range 44 west, Monona county, and elsewhere, a line or layer of rather large calcareous nodules forms a more or less distinct line of division between the denser lower loess and the more porous upper loess.

In Missouri Valley and elsewhere where English sparrows are abundant, the upper softer loess is often marked by numerous

* Several other sections near the Iowan drift border in northern Johnson and Iowa counties show yellow loess on the Iowan drift. 
boles excavated by the birds and used as retreats and probably for nesting. Such holes do not appear in the tougher lower loess.

The yellow loess is probably a composite formation consisting of at least two deposits, the source of the materials of whioh was affected by different drift-sheets, the materials being carried beyond the limits of the drift-sheet by streams and re-deposited as loess. It is impossible to determine the extent to which the Iowan drift contributed materials of this kind in our territory as its southwestern limits have not been ascertained. It is probable however that the lower yellow loess was derived at least in part from Iowan sources.

The Wisconsin has evidently contributed much material of this kind to the Missouri drainage, and the upper yellow loess is probably largely derived from this source.

The blending of the yellow loesses in Harrison and Monona counties, and in other territory beyond the limits of the later drift-areas, is probably due to their remoteness from the driftborders and to the similarity of the materials brought down by the later ice-slieets.

\section{YELLOW LOESS SECTIONS.}

Nearly 300 sections showing yellow loess were studied in the two counties, and fossils were found more or less abundantly in 127 of them. The sections are distributed throughout the upland areas along wagon-roads and streets, in gullies, on the faces of the steeper bluffs, in sand-pits and brickyards, and along the Chicago, Milwaukee and St. Paul railway, this being the only railway which cuts the uplands. This loess forms the most abrupt portion of the main bluff (as shown in the upper part of plate-XXI, figure 1, in plate XXXI, figure 2, and Plate XXXIII, figure 1) where it is also thickest, and in such situations slipping and faulting is common and numerous sections are exposed in this manner.

This slipping and faulting frequently results from the undermining of the underlying Aftonian sand and gravel, though the loess itself slips in wet seasons. Ordinarily however it persists even in vertical walls, and in artificial excavations the sides often remain undisturbed for several years. Such cuts are illustrated in plate XXXI, figure 1 , and may be observed in all the Mis- 


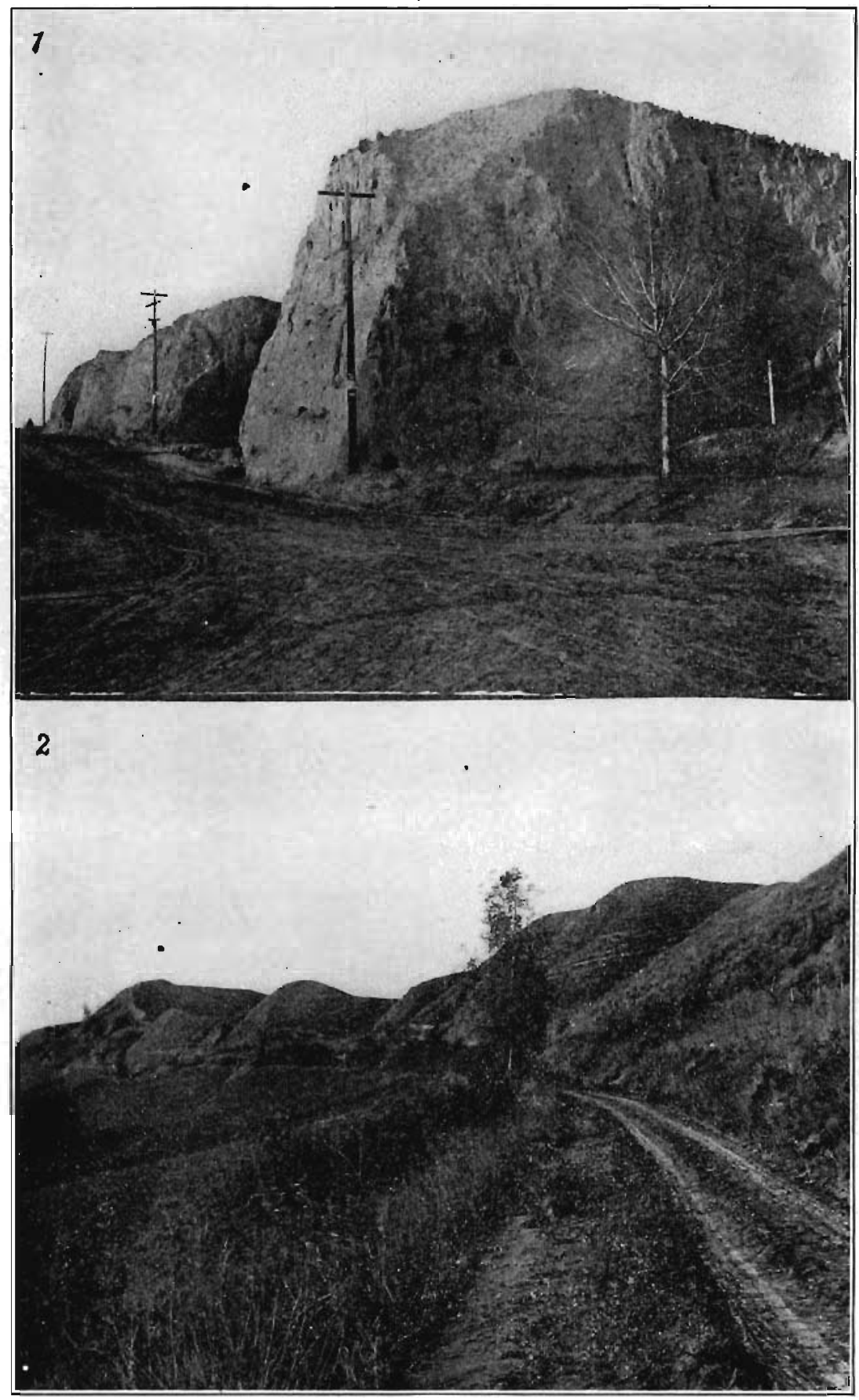

Plate XXXI. - Loess exposures. (1) Looking north on 5th street. Missouri Valley. Street cuts (pp. 309, 392). (2) Loess bluffs in southwest quarter section 3, township 82 north, range 44 west. Loveland and fossiliferous loess (pp. 280, 284, 372, 392, 400, 415). 
Blank pg faces pg 393 (vol.20) 
souri valley bluff cities and towns in Iowa, Nebraska, Missouri and Kansas.

Missouri Valley is the best locality for the study of the yellow loess within our territory, and one of the best in the entire Missouri valley, being equalled only by Sioux City and Council Bluffs, Iowa, and St. Joseph, Missouri, on the east side of the valley, and perhaps by Omaha, Nebraska, on the west side.

Missouri Valley is located in part on the southerly slopes of the point of highlands which projects southward between the Boyer and Missouri valleys. These highlands descend southward in a series of about five ridges, of which the westernmost one is the shortest and most abrupt, forming a prominent headland, and contains the Sinith brickyard section. (See page 369.)

Northward the same highlands form the southern slope of Snyders Hollow, which is shown in plate XXXIII, figure 2.*

Street-cuts and other excavations in this upland mass, to the number of sixty-four, were studied in detail. These sections vary from seven to thirty-five feet in depth, excepting the Smith section which, as already noted, exposes nearly ninety feet of the yellow loess.

On the more easterly ridges the lower yellow loess prevails, but on the western bluffs the lighter upper loess is well developed. Both are typical.

Neither part of the yellow loess is here very fossiliferous, but the lower yielded about twelve species of mollusks, all terrestrial, which were represented by quite a number of more or less scattered individuals. The upper loess yielded only a few individuals of Succinea ovalis, a species which is usually found eastward in rather low alluvial woods, but which occasionally occurs on even the treeless portions of the dry Missouri bluffs in western Iowa. In such cases it is uniformly smaller, evidently stunted by exposure to its environment, but identical with the fossil forms of the same species which occur in all the loesses of the region. $\dagger$

Fossils are much more numerous in other parts of our territory. Perhaps the richest exposure of fossiliferous lower yel-

*The western border of this highland mass, which here forms the Missourl bluffs, is illustrated in plate XXXIII, figure 1.

†The larger form of this Succinea is also found on lower grounds in western Iowa, and it is very common in some of the alluvial deposits described in this report. 
low loess is that in the Murray Hill section in the Missouri bluffs, and in the cuts along the Chicago, Milwaukee and St. Paul railway east of Mapleton.

In connection with the discussion of the yellow loess sections attention should be called to a number of sections showing the loess of the river benches. These benches are covered with loess, chiefly of the lower yellow type, as is shown by a number of sections. This loess is in every way typical, and, like the underlying formation of the benches already described, it is exactly the same as the corresponding formations described elsewhere in this territory, and simply emphasizes the conclusion that these benches are as old as any part of the inland loess-Kansan territory and that they are not river-terraces.

Some of the best of these loess sections are located as follows: HARRISON COUNTY BENOH SECTIONS.

1. A street-cut north of the Chicago and North Western railway station at Logan. Fossils.

2. A road-cut west of Dunlap on the north line of section 9, township 81 north, range 41 west. Fossils.

3. A road-cut near the northwest corner of the northeast quarter of section 5, township 80 north, range 41 west. Fossils.

4. A road-cut near the southwest corner of the northwest quarter of the same section. Fossils.

5. A road-cut in the northwest quarter of section 12, township 81 north, range 44 west, near Pisgah.

6. A road-cut in the southwest quarter of section 14 of the same township. Fossils.

7. Two road-cuts in the southeast quarter of section 15 of the same township.

8. A road-cut in section 23 of the same township.

9. Two road-cuts on the east line of the northeast quarter of section 22 of the same township. Fossils.

MONONA COUNTY BENOH SECTIONS.

10. A road-cut in the southeast quarter of section 30, township 84 north, range 43 west. Fossils.

11. A road-cut in the southeast quarter of section 2, township 83 north, range 44 west. 
12. Two road-cuts in the east half of section 11 of the same township. Fossils.

13. A road-cut near the middle of the east half of section 4 , township 83 north, range 42 west. Fossils.

14. A road-cut near the northwest corner of the northeast quarter of section 31 , township 82 nortll, range 43 west. Few fossils.

\section{Loess Fossils.}

The fossils of the loess of this region are all mollusks, and terrestrial forms here as elsewhere vastly predominate.

The following table gives a comparative view of the molluscan faunas of this region, from the Aftonian to the present time. The first column includes the fauna of the Aftonian beds; the second of the somewhat doubtful, though probably Aftonian, bed of manganese dioxide at Missouri Valley; the third of the bluish gray post-Kansan loess; the fourth of the yellow loess; the fifth of the various alluvial deposits described on succeeding pages; and the sixth the modern fauna.

FOSSIL AND MODERN MOLLUSCA OF HARRISON AND MONONA COUNTIES

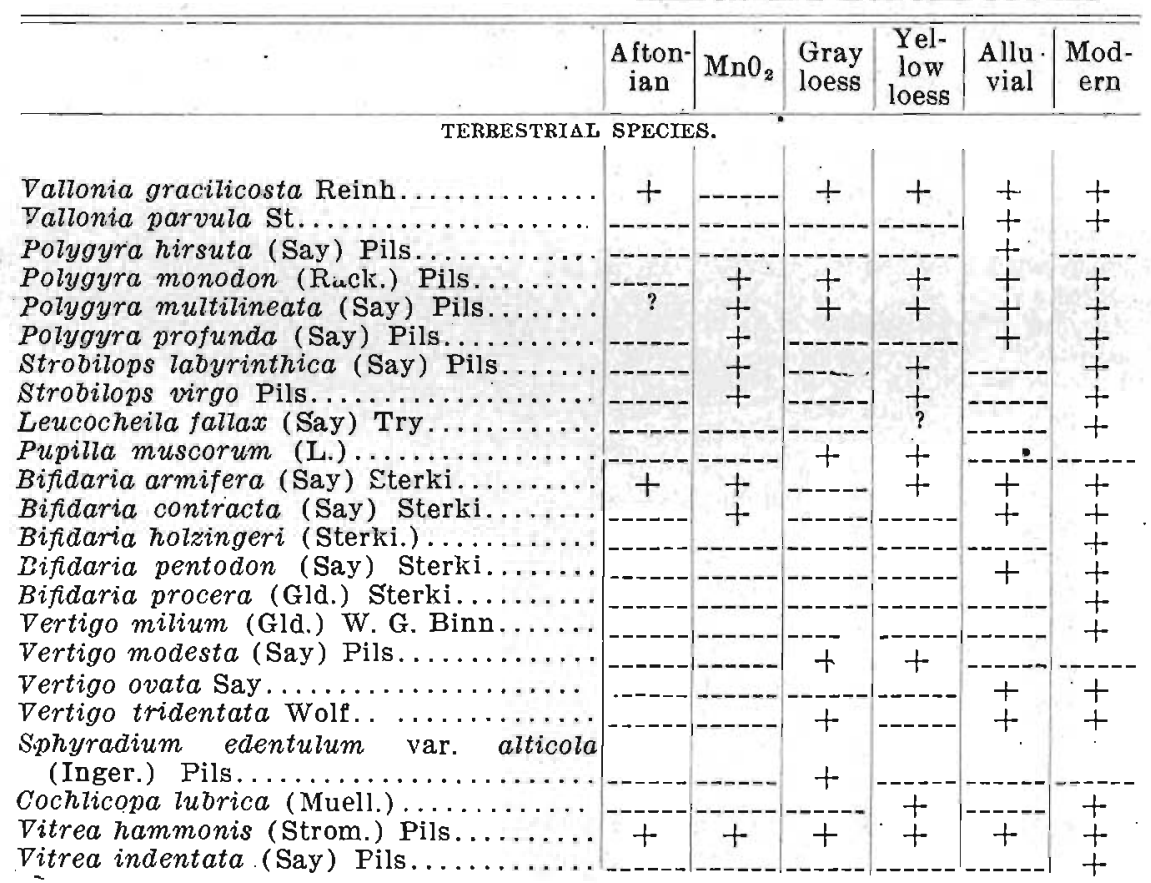


FOSSIL AND MODERN MOLLUSCA OF HARRISON AND MONONA COUNTIES Continued

\begin{tabular}{|c|c|c|c|c|c|c|}
\hline • & $\begin{array}{c}\text { Afton } \\
\text { ian }\end{array}$ & $\mathrm{MnO}_{2}$ & $\begin{array}{l}\text { Grry } \\
\text { loess }\end{array}$ & $\begin{array}{l}\text { Yel- } \\
\text { low } \\
\text { loess }\end{array}$ & $\underset{\text { vilu- }}{\text { Allu- }}$ & $\begin{array}{l}\text { Mod- } \\
\text { ern }\end{array}$ \\
\hline Euconulus fulvus (Drap.) Reinh......... & & + & + & + & 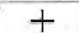 & + \\
\hline Zonitoides arboreus (Say) Pils.... & + & + & + & + & + & + \\
\hline Zonitoides minusculus (Binn.) Pils. & & & & & & \\
\hline Pyramidula alternata (Say) Pils... & + & + & + & + & & + \\
\hline Pyramidula shimekii (Pils.) Sh..... & & & + & + & & \\
\hline Pyramidula striatella (Anth.) Pils..... & + & + & + & + & + & + \\
\hline Helicodiscus parallelus (Say).......... & & + & + & + & + & + \\
\hline Punctum pygmaeum (Drap.) Binn...... & & & & & & \\
\hline 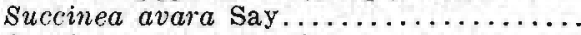 & + & + & + & + & + & + \\
\hline Succinea grosvenorii Lea.............. & & & & & & \\
\hline Succinea ovalis Say (=obliqua Say)... & + & + & + & + & + & t \\
\hline 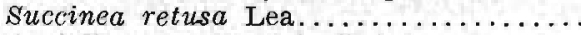 & + & + & --- & -1 & + & + \\
\hline Agriolimax campestris (L.)........... & & & & & & + \\
\hline Carychium exiguum Say........ & & + & --- & & & + \\
\hline Carychium exile Lea......... & & + & --- & & & + \\
\hline Helicina occulta Say........... & & + & + & + & + & --- \\
\hline Eggs of small snails........... & & & + & + & + & + \\
\hline
\end{tabular}

FRESH-WATER SPECIES.

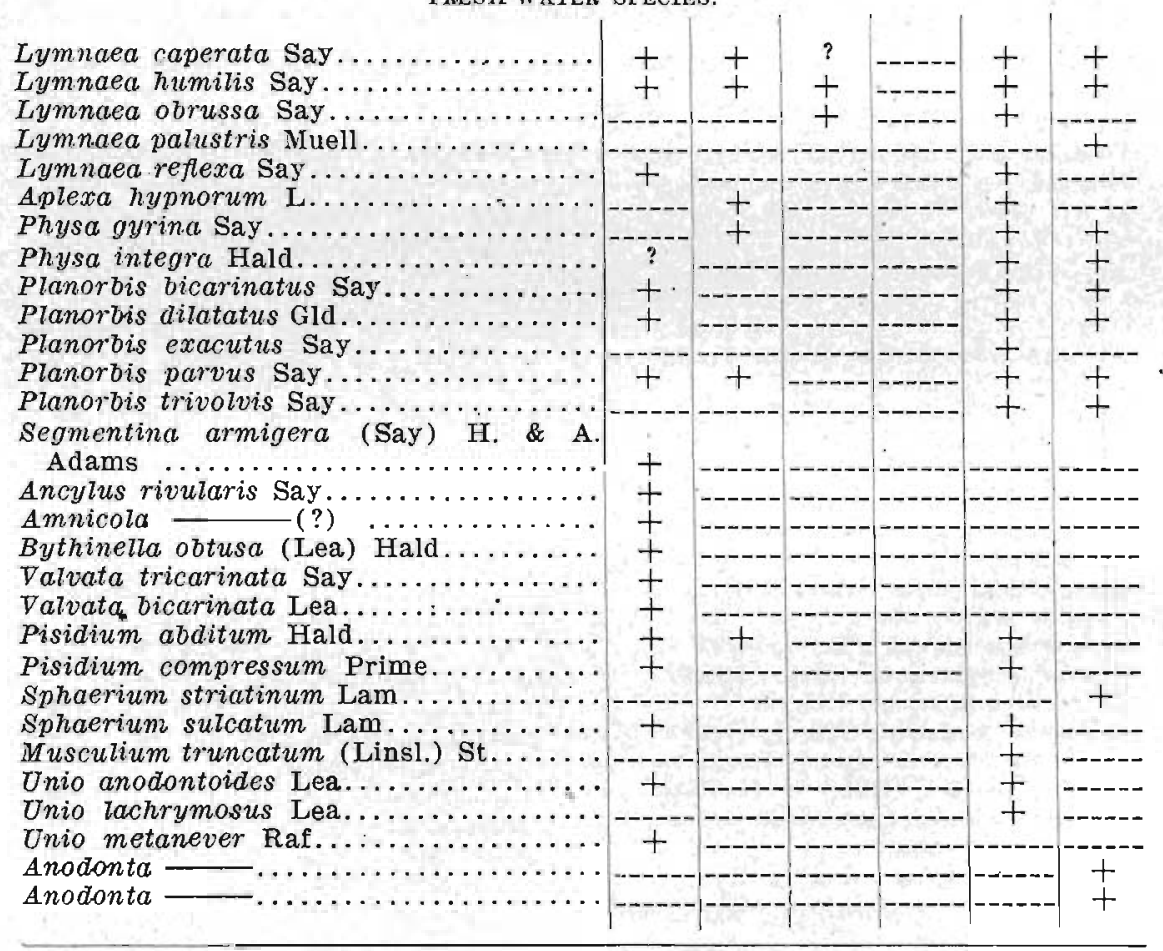

A comparison of the lists of fossils from the two loesses shows very little difference. Fven where species occur in one and not. 
in the other the difference is without significance as in each case the species is found in the other loess in some other section of the state. Such differences for the limited territory here considered are simply due to the uncertainties and inequalities of field work.

It will be noticed that with the exception of the Lymnæas which were found in restricted parts of but two sections of postKansan loess, the loess species are strictly terrestrial, and with the exception of Vertigo modesta and Pyramidula shimeki $i^{*}$ all live within the limits of the state, though three additional species, Sphyradium edentulum, Pupilla muscorum and Helicina occulta $\dagger$ are not found in the modern fauna of these counties.

Several terrestrial species which are found in the modern fauna of the region were not collected in the loess, or the specimens were doubtfully from the loess. All of these species have been found in the loess of other parts of the state and country. They are:

Vallonia parvula Succinea grosvenorii

Polygyra profunda.

Leucocheila fallax

Bifdaria contracta

Bifidaria holzingeri.

Bifiaria pentodon

\author{
Bifidaria procera \\ Vertigo milium \\ Vertigo ovata \\ Vitrea indentata \\ Punctum pygmaeum \\ Carychium exile
}

Vallonia parvula and Succinea grosvenorii are common on the modern surfaces of this region, but they are not common in the loess and seem to be comparatively recent additions to the fauna. Limax campestris is a slug and hence would leave no evidence of its earlier existence. Succinea retusa and Carychium exiguum though not aquatic prefer very moist places, and they are practically absent from the loess of this country, though at least the Succinea extends back to the Aftonian. It will be observed that the same is true of a number of the aquatic species which occur in both the Aftonian and modern faunas but are found very sparingly, or more frequently not at all, in the loess. This fact has an important bearing on the genesis of loess.

* Both of these species live in the dry regions of the southwest. For a more detailed discussion of the Pyramidula see the Bulletin from the Laboratories of Natura History of the State University of Iowa, vol. V, part 2, 1901, pp. 139-145.

$\dagger$ For the discussion of the distribution and variation of both fossil and modern forms of this species see the Proceedings of the Davenport Academy of Sciences. vol IX, 1904, pp. 173-180, and the Journal of Geology, vol. XIII, 1905, pp. 232-237. In our territory this species became extinct before the completion of the deposition of the yellow loess as it does not occur in the upper part of that formation. 
None of the species here listed, whether from the Aftonian, the loess, or the alluvium are entirely extinct.

Quite a number of the terrestrial species extend through all the formations included in the table, but in such cases they occur in the Aftonian and more modern alluvium only in comparatively small numbers and were evidently washed down from adjacent land surfaces. A few species of aquatic pulmonates, belonging to the genus Lymncea, and one bivalve, Pisidium compressum, are also found in all these formations, but they are rare (the Pisidium is very rare), in the loess though common in the waterlain Aftonian and alluvium.

The distribution of the mollusks in all these formations is similar to that of the modern forms. No single exposure will yield all the species in the list, just as no single limited area will support all the modern forms.

Certain species, such as Vallonia gracilicosta, Pyramidula striatella, Succinea avara, Succinea ovalis and Helicina occulta, are likely to occur in considerable numbers in the loess, just as they do on modern surfaces. Other species, such as Polygyra monodon, Vitrea hammonis, Euconulus fulvus, Zonitoides arboreus and Helicodiscus parallelus, are less abundant in any given cut or locality but are widely distributed, thus also resembling the modern representatives of the same species. Still others are rare and local in the loess as well as on the surface.

The vertical distribution of the shells in the loess is also very variable, suggesting that as the loess was forming surface conditions and the surface fauna changed, usually more or less gradually.

The distribution of the few aquatic pulmonates of the loess also resembles that of the modern forms. The smaller Lymnæas, which form the greater part of the aquatic pulmonate fauna of all the loess, are now found usually at the edges of ponds and sluggish streamlets, and when they occur in the loess they are usually found in bands or pockets which suggest a similar condition, and which probably represent the edge of a pond long since buried.

Taken collectively the molluscan fauna of the Aftonian and 
alluvium suggests aquatic and low-ground conditions, while that of the loess suggests terrestrial upland conditions.

The Genesis of the Loess.

The question of the genesis of the American loess has been under discussion for many years, and various hypotheses have been presented to account for the presence and the peculiarities of this deposit.

For many years American geologists quite generally accepted some form of the glacio-fluviatile hypothesis as sufficient to explain the phenomena of the loess, but more recently those who are most familiar with the subject have been inclined to favor the æolian hypothesis.

The writer has presented the æolian side of the case in a more or less fragmentary manner in a series of papers published within the past sixteen years, ${ }^{*}$ and he does not purpose here to enter into a detailed discussion of the genesis of the loess, this being reserved for a more extended paper now in preparation.

However the work in Harrison and Monona counties and in adjacent territory has brought out certain facts which throw light on the genesis of the loess and these are here briefly discussed.

It may be stated at the outset that these facts give support to the æolian hypothesis and are in themselves sufficient to establish it and to show the utter impossibility of the existence of glaciofluviatile conditions during the deposition of the loess.

Briefly stated they are as follows:

1. The presence and relative position of the several loesses is consistent with the conclusion that they are interglacial (the last post-glacial) and that they were deposited in a comparatively mild climate. This precludes the possibility of a glacial or subglacial climate in which shores of ice might at times retain large bodies of water, and increases the difficulty of accounting for the presence of loess on the highest ridges under the glacio-fluviatile hypothesis.

* See the Loess Papers in the Bulletin from the Laboratories of Natural History of the State University of Iowa, vol. V, 1904, pp. 298-381, containing references to earlier papers; the Loess of the Misouri River, Proceedings of the Iowa Academy of Science, vol. XIV, 1908, pp. 237-256; a paper on the Genesis of Loess a Problem in Plant Ecology, loc. clt. vol. XV, 1909, pp. 57-75; the Loess of the Paha and River Ridge, loc. cit., pp. 117-135; and the Nebraska "Loess Man", Bulletin of the Geological Society of America, vol. 19,1908 , pp. 243-254. 
2. The topography of the roughest loess-covered areas where the loess is best developed is distinctively wind or snow-drift topography ' see plate XXI; plate XXII, figure 1; plate XXIII, figure 2 ; and plate $X X X I$, figure 2). In such places the thickest loess always occupies the highest part of the ridge, and was evidently formed from dust which was deposited in much the same manner as snow is whipped up to form drifts. During dry summers the writer has frequently observed little trains of dust thus carried upward between the tufts of the scant vegetation (see figure 34 and plate XXXIII, figure 1) on the loess bluffs along the Missouri valley, and sometimes this was done even by gentle winds or mere intermittent puffs.

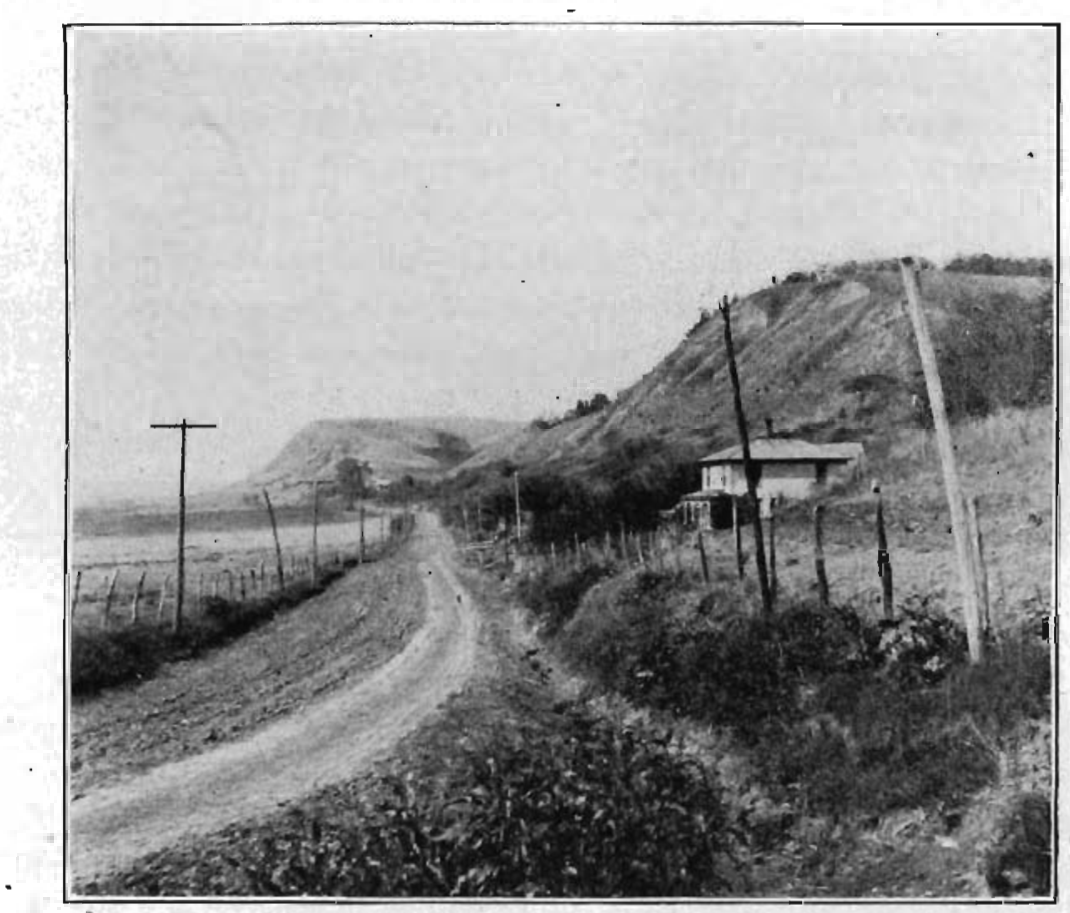

Fig. 32. The abrupt treeless bluffs above Missouri valley, lowa. This represents the prevailing type on the east side of the river. (See p. 403.)

The fact that such transportation of material takes place on the very surfaces under discussion is also brought ont by figure 2 , plate XXIII. This represents the loess ridges north of Turin in Monona county, and the view is taken looking a little west of 
south, after much of the snow had disappeared. Here the sharp crests of the loess ridges are made still higher by the remnants of snow-drifts which were deepest at the very top of each crest. These drifts were built up chiefly by gentle winds for during: the winter of 1909-10 (when the photograph was taken) there was very little violent drifting of snow.

3. The source of the loess materials is here plainly discernible. During most of the days of the open warmer parts of the year winds prevail, and even on merely moderately windy days it is possible by looking out across the valley from the loess bluffs to locate all the larger bars along the Missouri river by the columns and clouds of dust which rise from them. There is always more or less of this dust in circulation, but on very windy days the atmosphere is dense with it, and enormous quantities of material are thus transported. On the bars near the Blair railway bridge in Harrison county, and at other points,

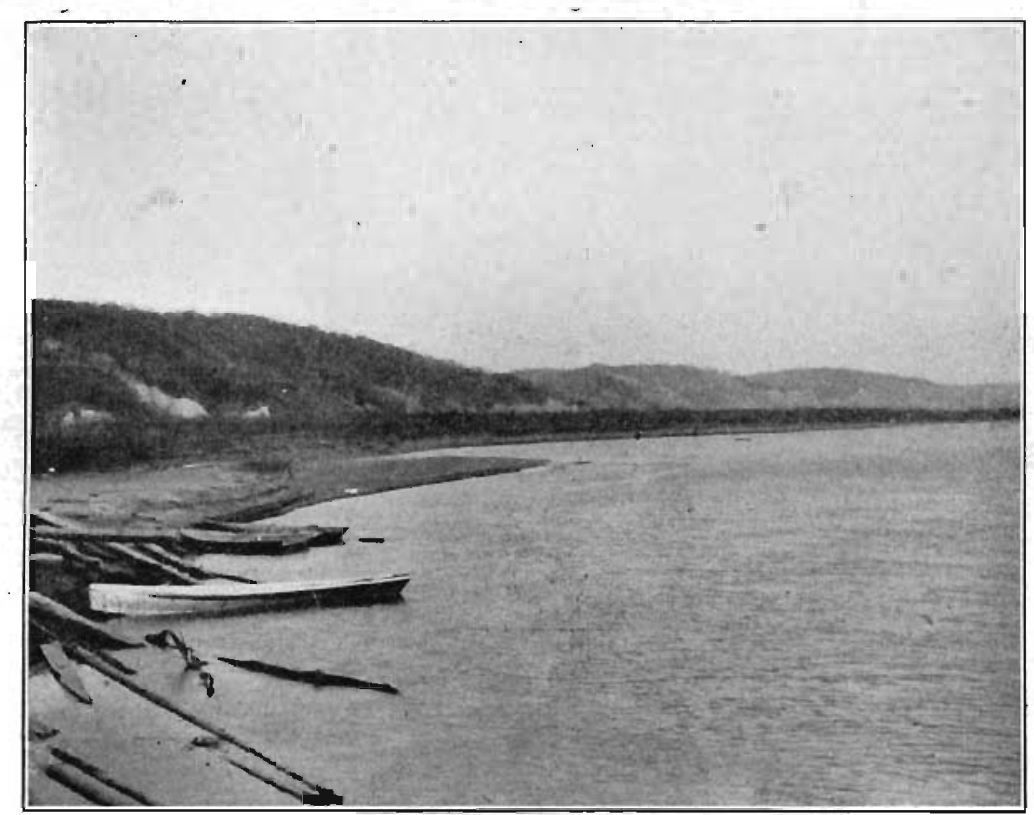

Fig. 33. The wooded bluffs above Florence, Neb. These rounded wooded bluffs are the prevailing type on the west side of the Missouri river. (See p. 103.) 
the writer has observed the manner in which this dust is often released. Much of the silt carried down and deposited by the Missouri is very fine and is variously mingled and interstratified with sand. Where loose sand is at the surface on the exposed river-bars it is frequently driven by the wind over the dry silt which it reduces to dust, much of which is then carried away to be deposited in part on the uplands as loess. As each succeeding rise in the river brings new burdens of silt the supply of dust material is perpetual and inexhaustible.

4. The loess is greater and more irregular in thickness along the bluffs of the valleys and thins out inland where it also commonly forms a more regular veneer. The bluff-loess is also made up of somewliat coarser material than that which forms the more remote inland loess. Both facts are consistent with the æolian hypothesis for the thickest deposit is nearest to the source of supply, and both suggest that a large part of the dust forming the unequal bluff loess drifted into its present position in the

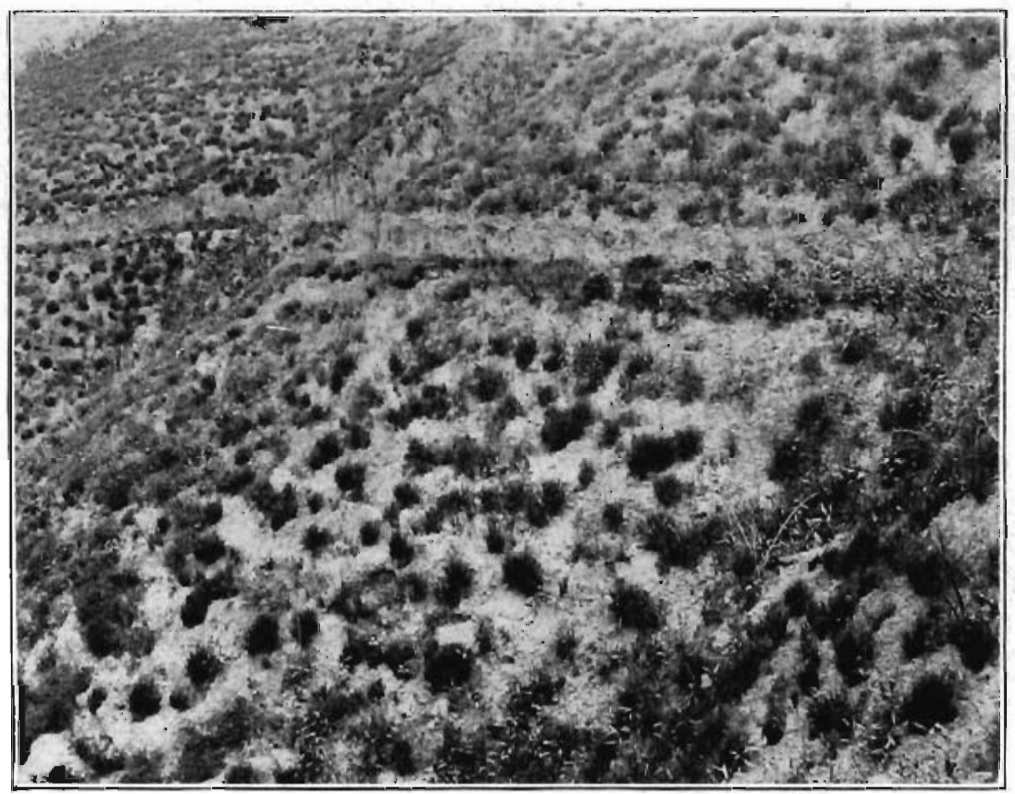

Flg. 34. A portion' of the : face of the loess bluffe at Council Bluffs, Iowa, showing the tufted rerophytic vegetation with large bare spaces between the plants Dust may therefore be whipped up these abrupt slopes much as snow is driven up the face of a snow-drift. (See p. 400.) 
manner already described, while the finer and less abundant dust which remained suspended in the air longer was carried inland to be finally deposited as finer loess in more uniform strata. The loess formed in the shelter of groves would be especially uniform because evenly deposited by settling without drifting.

5. The distribution of the thickest portions of the loess deposits is best explained on the basis of the æolian hypothesis. They are found chiefly on the bluffs on the east side of the Missouri valley, (compare figures 32 and 33) and on the west or northwest bluffs of the larger tributary valleys all of which extend in a general southwesterly direction, thus exposing these bluffs to the prevailing southerly and southwesterly winds of the warmer parts of the year. These thicker deposits do not oecur on the rounded bluffs on the southeastern side of the tributary ralleys, excepting where the line of the bluffs on this side is so turned that a portion of them is exposed to the southwest. In short the distribution of the thickest loess coincides with that of the abrupt bluffs with cat-steps which have already been described. (Compare figures 1 and 2, plate XXII.)

Similarly the edges of the river-benches where exposed in the same manner show a thicker accumulation of loess on the exposed side. Thus the edge of the Soldier river bench in the southwest quarter of section 29, township 82 north, range 43 west, shows the ordinary abrupt wind-topography with cat-steps, and the southwestern and western edge of the great Belvidere bench (see plate XXIII, figure 1) is similar and averages about fifty feet more in lheight than the remainder of the bench. Most of this additional height is evidently due to the greater accumulation of the yellow loess.

It should also be noted that the thickest deposits of loess occur along the streams with the broadest valleys and the largest and most numerous bars, and this is true not only of these counties but of the entire Missouri valley.

6. The lamination of the loess, which, when discernible, quite uniformly follows the vertical contours of the hills, also suggests deposition by wind, for it is very similar to the lamination which may be observed in sand-dunes, such as that illustrated in figure 35, which have been built up gradually by comparatively mod- 
erate winds. It is wholly unlike the regular, more or less horizontal, continuous lamination exhibited by silts.

Udden has reported horizontal shearing planes in both loess and "gumbo" (Loveland) near their line of contact," and it is probable that he refers to the ordinary lamination of the lower part of the loess. Inasmuch as this lamination is most pronounced in the lower parts of the thickest deposits it is possible that the pressure of the upper mass is the cause of the lamination, and that shearing planes are produced as suggested by Udden, but the fact that the lamination follows the vertical contours, and the further fact that sand-dunes show lamination of the same type, point rather to an æolian origin.

- These shearing-planes may have been produced, however, by the slipping of large masses of loess, etc., on the ridges forming the bluffs, a phenomenon by no means uncommon. In that case all the plastic materials, whether loess, Loveland or drift clay, would show similar effects. Such slipping does not, however, take place where the slopes are less abrupt and could not explain the lamination in the loess which is so common even where creeping or slipping of the loess could not take place.

7. The fossil land shells of the loess of this territory present again one of the strongest arguments in support of the æolian hypotheses. They are abundant and widely distributed, while aquatic shells are almost absent, and the few which. were found, less than a dozen specimens, belong to species which ordinarily live in small ponds or along the borders of small sluggish streams. Species belonging to larger bodies of water are notably absent, here as elsewhere, from the loess.

The distribution of the land-shells of the loess has already received attention, and the occurrence of the same species in the modern fauna is brought out in the table of mollusks. It is sufficient here to state that the vertical and horizontal distribution of these species, when compared with the distribution of the modern forms of the same species, suggests that the loess shells were buried in situ on old land surfaces which they inhabited. Then as now there were groves in which snails were quite abun-

*From Pottawattamie county, Iowa, in the Journal of Geology, vol. X, 1902, pp. 245-251. 
dant, and in such places shells are abundant in the loess; then as now there were mollusk stragglers at the edges of the groves, in the scattered clumps of bushes on the prairie, and rarely on the prairie itself, and in such places the fossils are few and scattered; and then as now there were more xerophytic prairie areas on which no mollusks lived, and when these were covered with loess it contained no shells.

The entire loess fauna suggests surface and climatic conditions not materially different from those which prevail in the same region today. Indeed, if there is any difference it suggests a somewhat drier climate since it contains species such as Vertigo modesta, Sphyradium edentulum, Pupilla muscorum and Pyramidula shimekii which are today restricted to, or most abundant in, the drier sections of the far west.

\section{THE ALLUVIUM.}

The alluvium is by no means the least interesting and important of the surface deposits in Harrison and Monona counties. Not only does it form the great alluvial plain of the Missouri and its tributaries, but it contains animal remains which are deserving of attention because of the light which they throw upon the conditions which have prevailed in the region in comparatively recent time. The great alluvial plain is more or less variable in composition, as has been noted. A large part of its area is covered with a rich black alluvial soil which is sufficiently loose and well drained to make excellent farming land. Here and there in the less readily drained tracts there are areas of "gumbo", a heavy, impervious, usually dark-colored deposit, which may be derived in large part from the Nebraskan till. This gumbo is now farmed to advantage, where not too low, by being cultivated while dry. Large tracts of gumbo border both the West Fork and the Little Sioux, occupying most of the area subject to inundation, and it appears more or less abundantly in other parts of the Missouri plain and its larger tributary valleys.

Sandy tracts, representing old river bars, also appear here and there, and the Missouri river is bordered by interrupted sand-dune areas which are derived from the bars of the great stream. The largest of these dune areas is located near the Blair railway bridge west of California Junction. 
The usual organic remains are found in these alluvial deposits. Buried sticks and logs are common, and pond and fluviatile shells belonging chiefly to the genera Spharium, Pisidium, Physa, Lymncea, and Planorbis are found frequently in the alluvium of stream and pond.

However, sections are neither numerous nor deep and only such as are exposed by recent shallow erosion are available for ordinary study. Deeper borings, as in the Missouri Valley wells and elsewhere, indicate that the deeper deposits consist largely of sand and gravels. In the Missouri Valley railway wells sand was found at a depth of thirty-five feet, and rock was reached at ninety feet. Some bowlders were found near the bottom of the deposit. At the Blair bridge, on the Iowa side, bed rock is forty-five feet below low-water, and it dips to the west, being about five feet lower on the west side.*'

But while the alluvial deposits of the great valley excel in magnitude and extent, they are in many respects less satisfactory for study than those which in some places border the valley along the bases of the bluffs, or follow the numerous tributaries into the region in which uplands predominate. These border deposits present many more sections, and both their structure and contents can be more thoroughly studied.

Moreover the smaller tributaries have so deeply cut into the alluvium of their own earlier deposition that they have exposed fine sections in all parts of our territory.

These alluvial deposits usually consist of fine silt which is ordinarily dark in color, sometimes blue-black, but occasionally varies to yellowish. It is more or less distinctly laminated and interstratified with various bands and streaks of sand and fine gravel; when wet it becomes very soft and sticky, and in the bottom of the deep gullies cut by the small streams it usually forms a treacherous mire. In the lower part it frequently contains numerous large iron root-tubes similar to those of the postKansan loess, and is occasionally marked with ferruginous lines and streaks.

Irregular calcareous nodules are, also sometimes present, and

* Reportea by Mr. J. S. Wattles. 
the shells of mollusks present the usual mixture of land and fresh-water species which is ordinarily found in modern alJuvium and in the drift along streams. A list of the species collected from the alluvium of Harrison and Monona counties is given in the table of mollusks. All are living in the state today.

\section{The Bison in lowa.}

The most remarkable feature of the alluvial deposits bordering the smaller creeks, however, is the presence in them of large numbers of skulls and bones of the bison, or buffalo, together with less common remains of the elk and the Virginia deer.

The existence of the bison in considerable numbers in Iowa has long been disputed. The question was again precipitated in recent years by Professor Herbert Osborn* who accepted the evidence as conclusively proving the existence of the bison in Towa. This conclusion was challenged by Mr. Robert L. Garden, who later published his objections in book form, $\uparrow$ and the discussion brought out the fact that isolated skulls and bones of the bison had been frequently found in Iowa. The writer has personal knowledge of such discoveries in Woodbury, Mills, Lyon and Cerro Gordo counties besides a number of cases in Harrison and Monona counties.

Mr. Charles I. Whiting presented a skull of a bison which was taken from the creek alluvium in section 10 of Center township, Monona county; Mr. Edwin Quick reported the discovery of two bison skulls in the southeast quarter of section 30 in Cooper township, Monona county, and the antlers of a Virginia deer in a well in the southeast quarter of section 16 in the same township; Mr. C. G. Kiefer found a part of a bison's skeleton in section 24, township 80 north, range 42 west, in Harrison county; and Smith's History of Harrison county contains an account of other such discoveries and of the killing of a bison in that county (pp. 123-126).

It is also worthy of note that the report of the Long Expedition (loc. cit.) states that on February 22, 1820, several buffaloes were killed near the Sioux river. This was probably the

\footnotetext{
* January number of the Annals of Iowa, 1905.
}

the paper is entitled "Did the Buffalo ever exist in Iowa?", and was published In 1907 by Robert L. Garden in a volume containing in addition a History of Scott lownship, Mahaska county, Iow 8 , and War Reminiscences. 
Little Sioux and within our territory.* While the foregoing cases, and many others like them. demonstrated the occasional occurrence of the bison in Iowa at a time not very remote, they did not conclusively prove that the animals were numerous. It remained for Harrison and Monona counties to furnish the conclusive evidence that the bison did occur in Iowa in large numbers. This evidence was furnished by two localities, one in each county, and consists of a large number of skulls and various parts of skeletons of the bison, associated with a few antlers and bones of the elk and the Virginia deer. The collection from the Monona county locality along Beaver creek is represented in plate XXXII, figure 2.

A more detailed description of the two localities mav be of interest.

The Monona county bone beds are located on the farm of $\mathrm{Mr}$. G. F. Struble in Jordan township. They extend along Beaver creek for some distance, the best exposures being located in the northwest quarter of section 17, township 83 north, range 43 west, and in the southeast quarter of section 8 in the same townsbip.

Large numbers of bones had previously been taken from this deposit by Messrs. Struble, Mathiasen and Babcock, and these gentlemen also assisted Professor Calvin and the writer in making further collections and investigations.

In the best part of the exposure, a portion of which is shown in plate XXXII, figure 1 , the bones were buried to an average depth of about fifteen feet, and were exposed in the deep gully cut by Beaver creek.

This gully is here about eighteen feet deep, and its greatest width is about thirty-five feet. The lowest four feet of the exposure consists of a tough blue-black alluvial layer containing in some places, especially near the base, a large number of nearly vertical ferruginous root-tubes. Upward the material becomes somewhat lighter in both color and texture. Streaks of sand and fine gravel occur throughout. Bones were found in both the

* In the same report Major Long describes the journey across southwestern Iowa, and records (in volume II, p. 108) the following statement May 24th, 1820: "Remains of bison, as bones. horns, hoofs, and the like are often seen in these plains, and in one instance, ... We discovered the recent track of a bull; but all the herds of these anlmals have deserted the country on this side of Council Bluffs. The bones of the elk and deer are very numerous .. . and the living anlmals are still to be found in plenty." 


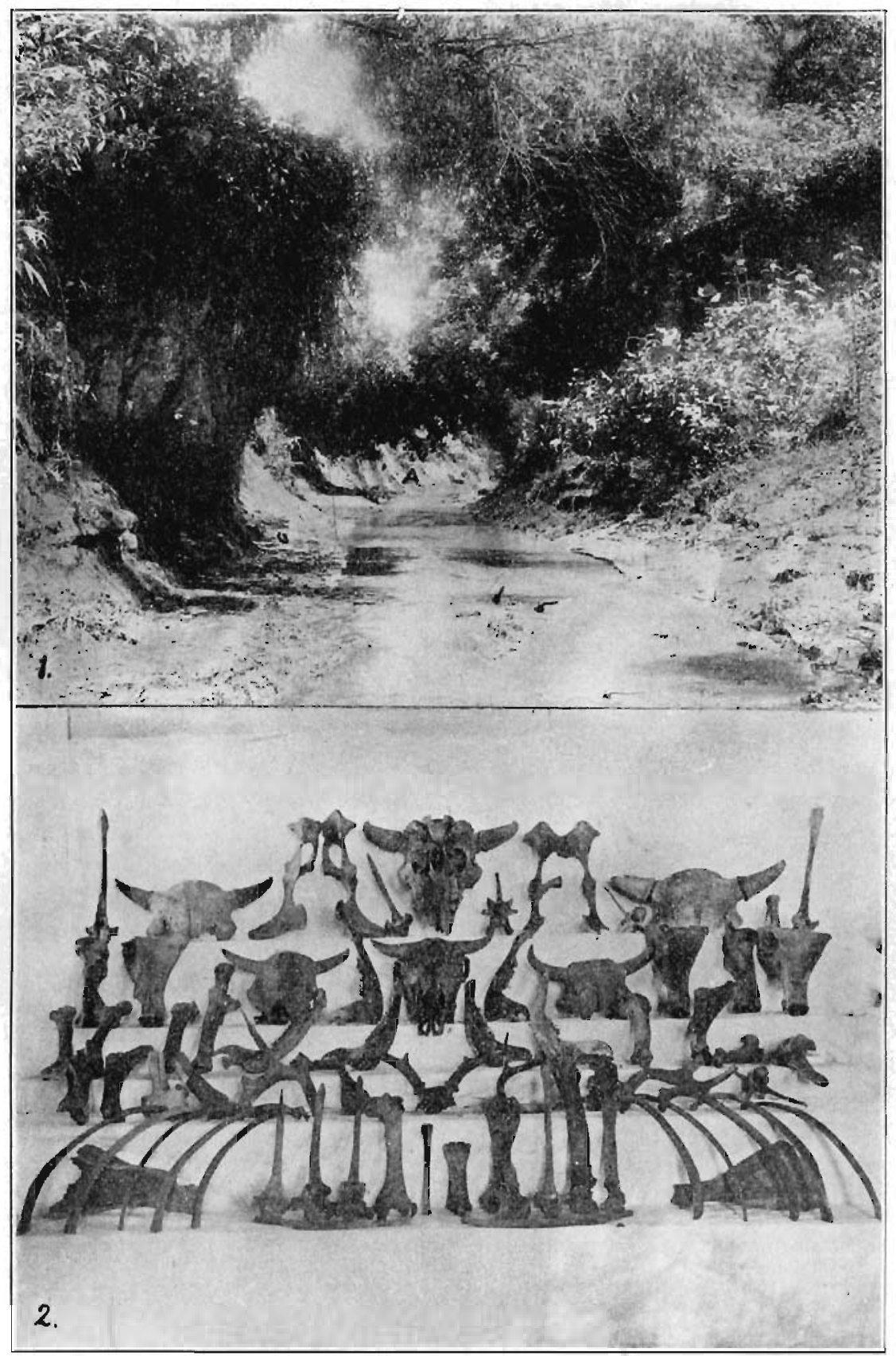

Plate XXXII.-Beaver creek alluvial bed and bones. (1) Beaver creek gully, lonking east. (A) Buried beaver dam (pp. 298, 408). (2) Bones of bison, elk
and Virginia deer (see p. 408). 
Blank faces pg. 409 
upper part of the lowest tough stratum and in the lower part of the upper layer. They were found projecting from the banks, such as the one shown to the left in figure 1, plate XXXII, for a considerable distance, and evidently represent the remains of many animals.

An old beaver-dam, buried to a depth of about twelve feet, was found at the point marked $A$ in the figure. Some of the sticks plainly showed the marks of beavers' teeth. Numerous shells (listed in the alluvial column of the mollusk table) and bits of carbonized wood were associated with the bones.

Mr. Struble reports that thirty years ago there was no gully at this point and that it was possible to drive across the creek. He says that the creek has done most of its cutting in the past ten years.

The Harrison county exposure is located along Hog creek chiefly on the farm of Mr. Lester Adams in the northeast quarter of the southeast quarter of section 14, township 79 north, range 42 west, near Logan, and extends to the adjoining southeast quarter of the same section.

The gully is here cut into alluvium to a depth of from eight to twelve feet. The alluvium presents the same structure as in the Struble section, but the exposed part of the stratum containing the iron root-tubes is at least six feet deep. There are streaks of sand and gravel, ferruginous lines and cloudings, scattered irregular calcareous nodules, and many shells, besides the numerous bones of the bison and elk, which appeared chiefly about half way up the bank.

The alluvium which forms the banks and bed of Beaver and Hog creeks makes a very deep, soft mire when wet, and it is evident that during the period of aggradation by the creek the animals which came down to drink were mired and finally buried in the ooze of the creek-bed.

This explains the excellent state of preservation of the bones, for exposure to the air would have long since caused them to crumble. It also explains the great preponderance of the skulls and bones of males, which is striking: wherever bison remains are found in Iowa. Very few skulls of females were found among those examined. The three lower skulls in figure 2, plate XXXII 
are those of females. The greater number of remains of males is evidently due to the fact that the heavier males had greater difficulty in extricating themselves from the mire and were overwhelmed. This would be especially true of old animals, and it is evident that these skulls belonged chiefly to such individuals.

The abundance of these bones in the alluvial beds warrants the conclusion that the bison was once common in Iowa, for the buried skeletons undoubtedly represent only a small part of the fauna of their time since only those which were buried in mire were preserved, all others disappearing completely.

In addition to the two great exposures here discussed there are numerous alluvial exposures which have yielded shells of mollusks only. These present the usual mixture of land and freshwater forms found in alluvium, and are included in the mollusk table. The best of these exposures were observed at the following points :

In Harrison County.

1. In the deep and narrow gully cut by Stowe creek in the southeast quarter of section 6 , township 81 north, range 43 west.

2. North of the county line exposure in section 5, township 81 north, range 44 west. At the base of the bluff along the road shell-bearing alluvium is exposed to a height of ten feet. It contains bivalve shells also.

3. A deep gully in the southwest quarter of section 7, township 79 north, range 43 west. This is the greatest of these gullies, reaching a depth in some places of more than forty feet.

4. A low exposure east of the manganese dioxide bed in Snyders Hollow.

5. The first road-cut south of the Peyton sand-pit south of Pisgah also shows an alluvial deposit with some calcareous nodules, numerous large land shells and a few Unios. The terrestrial shells are Polygyra profunda, Pyramidula alternata and. Succinea ovalis.

In Monona Countr.

6. Several sections along the road north of the Harrison county line in section 34, north of exposure (2) and similar to it.

7. Along Mucky creek southeast of Mapleton.

8. Along Rock creek south of Ute. The section is eight tc ten feet deep. 


\section{THE SAND-DUNES.}

As lias been noted there are sandy areas on the alluvial plain of the Missouri, especially in close proximity to the river. The finest of these sandy areas in our territory is located in Harrison county near the Blair railway bridge.

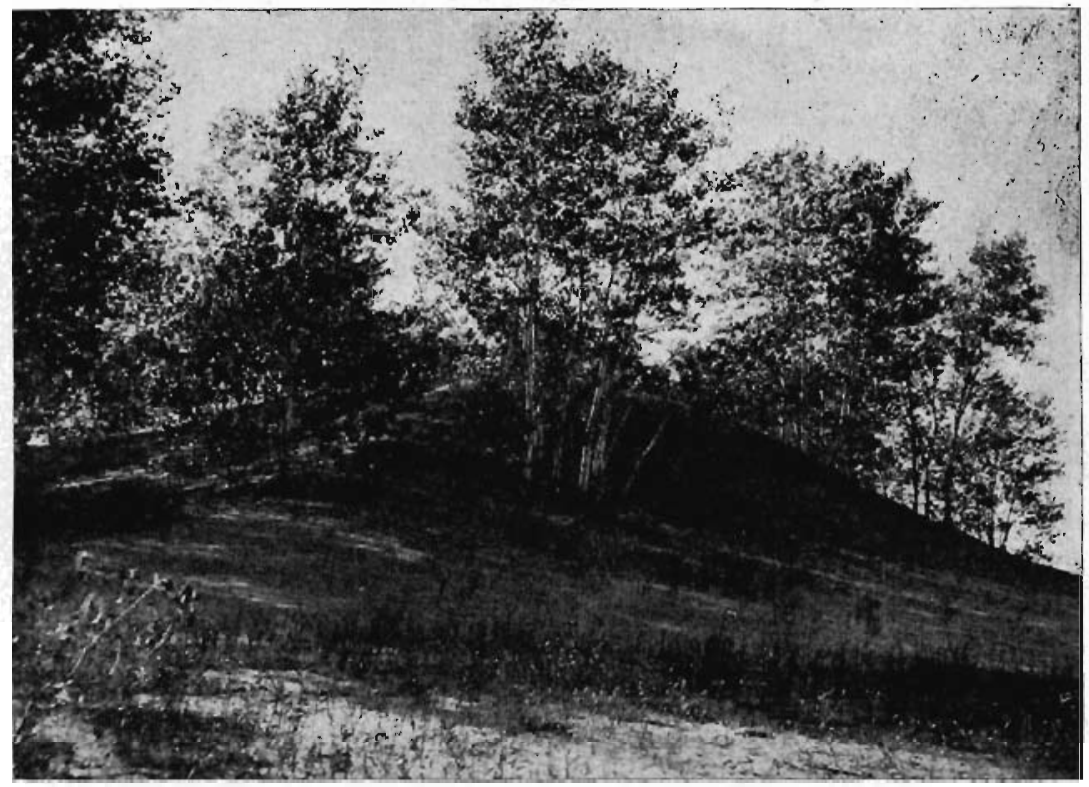

Fig. 35. A large sand-dune, with cottonwoods, west of California Junction, Harrison Co., Ia. Sections of this dune showed laminated sand clearly. (See p. 411.)

Here the sand lias been heaped up into distinct dunes, some of them more than twenty feet high, which are usually formed around a clump of willows or young cottonwoods. At first the dune is bare, as in figure 35 , but soon a scant xerophytic vegetation gains a foothold and finally covers the surface, as illustrated in figure 36. The plants which first appear are for the most part Leguminose which develop root-tubercles with nitrifying bacteria and are thus able to hold their own on the barren sands. All the Leguminose which are listed in the sand-dune column showed large numbers of root-tubercles. The older dunes and sandy areas are covered with a cottonwood forest which is usually fringed with the Missouri willow and other shrubs. 


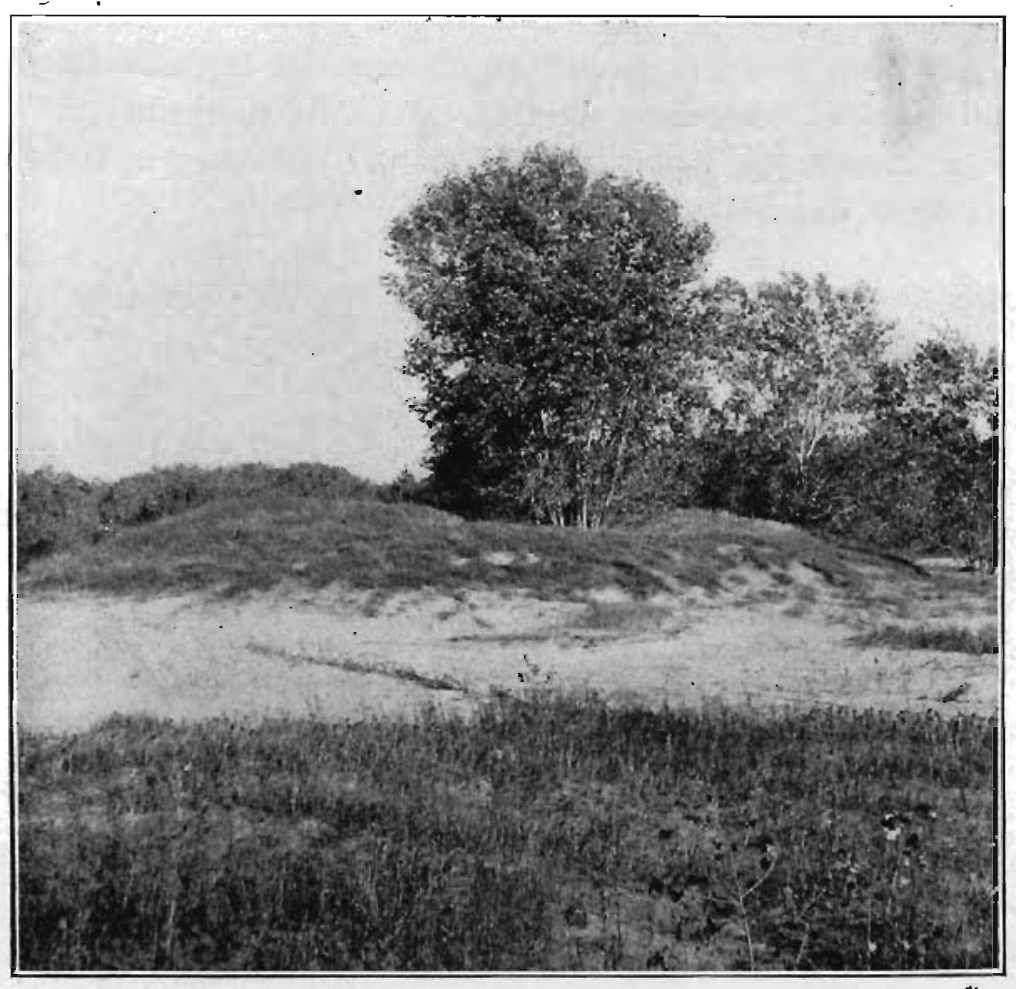

Fig. 36. A sand-dune on which plants (chiefly Cassia chamaecrista) have become established. The dune is now flxed and is beginning to form a flner soll. The trees are cottonwoods, and are responsible for the formation of the dune. Nearly all the plants on these dunes are leguminose, with abindant roottubercles containing nitrifying bacteria. Harrison county, Iowa. (See p. 411.)

On windy days the loose sand is freely shifted about; clouds of dust rise from the sands and are carried across the valley.

\section{MOUNDS}

Practically every prominent point along the loess bluffs on the Iowa side of the Missouri valley between Sioux City and Hamburg, shows one or more burial mounds constructed by the aboriginal inhabitants of this region, and Harrison and Monona counties have their fair share.

It is scarcely the province of this report to take up the discussion of a problem which involves archæological and ethnological questions, but it is proper that attention should be called to the richness of the field which on the Iowa side has remained 
almost untouched save for the occasional investigations of Mr. Robert F. Gilder of Omaha who has made many interesting discoveries on the Nebraska side of the river, and for the efforts of local amateurs who have not made systematic studies of the mounds, but have contented themselves with making collections of their contents. Several interesting collections of this kind are known in Harrison county, those belonging to Mr. J. D. Hornby and Dr. Weeks of Logan being perhaps most noteworthy.

The mounds seem to have been built up chiefly on the upper yellow loess along the more prominent bluffs of the Missouri and its larger tributaries, and frequently contain human skeletons accompanied by various trinkets, such as beads, shells, occasional pieces of pottery, etc.

They are of special interest because they so frequently contain shells and fragments of shells of freshwater mussels (Unios) and these have been regarded as evidence that the loess (of which the mounds are constructed) is of aqueous origin.

A particularly interesting mound was carefully examined by Mr. George H. Culavin of Missouri Valley. It was discovered on the ridge north of the entrance to Snyders Hollow about eightyfive feet above the valley, and contained the skeleton of an adult male and parts of skeletons of two children.

The large skeleton, which is now in the collection of the State University, was buried in a sitting or reclining posture, facing toward the south. The skull was about three feet below the surface, and above it, evidently intended for protection, was a layer of much decayed bur oak sticks and small logs, some of them reaching more than six inches in diameter. Mussel-shells were found in the upper stratum, and fragments were also strewn on the slope near the mound. The skeleton is almost complete and evidently belonged to an individual whose height exceeded six feet. The limb bones are long and rather slender, like those which are commonly found in the mounds of this region. The right forearm was crippled as the radius was broken and the ends failed to unite. The skull is in fine condition, and contains teeth which are remarkably regular and perfect, though somewhat worn with age. 
Various articles of interest accompanied the skeleton. There were two pipestone pipes; more than two dozen perforated bony cores of bears' claws which evidently formed a necklace; a bone scraper; a mass of ochre which was so shaped and situated that it had evidently been carried at the belt in front in a pouch; a badly rusted tube which probably formed the barrel of a short rifle or long pistol; a wooden key of some musical string instrument with flattened head and wrapped with flattened wire; several small hawk-bells; a flint arrow-head; flattened copper tubes, -probably bangles; a mink's skull and two smaller skulls probably belonging to the weasel; the lower mandible of a large bird; and various unidentifiable metallic fragments.

Another interesting mound was found by the writer on the detached ridge south of the Chicago, Milwaukee and St. Paul railway near Grant Center. Shallow excavations and a superficial examination revealed human bones, shell-beads, copper bangles and the ever-present shells of Unio which have been so generally carried to the mounds of the loess ridges by human hands.

All the species of fresh-water mussels found in these mounds, which have thus far been identified, are modern, and live today in the streams of western Iowa and eastern Nebraska.

The mounds of western Iowa should be carefully and systematically studied before they are ruined by the haphazard methods of the mere collector.

\section{ECONOMIC PRODUCTS}

\section{Solls and their Products}

The most valuable products of Harrison and Monona counties, iike those of all the prairie counties, are those which are derived from the soils.

The soils of the bottom-lands consist of rich alluvium, with irregular strips of sand and occasional larger areas covered with. a heavy gumbo. The better drained alluvium forms a very rich soil and the gumbo is quite productive, and if worked when dry may be very satisfactorily cultivated. The sandy areas are now 
used to some extent for the cultivation of watermelons, etc., and they should make very satisfactory truck gardens.

The bottom-lands subject to overflow are at present serviceable only for the growth of native hay, of which great quantities are produced. Large areas of this kind have already been reclaimed, and if the drainage operations now under way prove entirely successful still larger additions to the tillable area will be made.

The soil of the uplands consists of loess almost exclusively and in the interior portions where this retains a large amount $0_{i}^{\prime \prime}$ humus it forms a rich prairie soil, particularly on the riverbenches, which are famed for their fertility. Where the upper yellow loess is developed in the bluff areas but little humus is formed and retained, and the yellow loess appears at the surface. Where not too steep for cultivation even this is very productive, being especially adapted to the cultivation of fruit and alfalfa. The latter can be grown upon all slopes which can be cultivated and while it grows more luxuriantly on well-drained, richer soils it will produce a profitable crop on the drier yellow slopes which will produce but little else. A Monona county alfalfa field is shown on the lower slope, below the road, in plate XXXI, figure 2.

The driest ridges, covered with native grasses, are at present used for pasture.

The cultivation of fruit is proving very successful and should be extended. The sheltered valleys in the bluff territory should largely be devoted to this use.

Perhaps the finest orchard in our territory is that belonging to Mr. C. H. Deur of Missouri Valley (see plate XXV, figure 2) and located in section 1, township 78 north, range 44 west. It covers an area of sixty acres and contains chiefly apple trees set out in 1897,1898 and 1899. It is located on the slopes bordering the Boyer valley and presents a variety of exposures, but on the whole it is protected from the southwesterly winds. Mr. Deur considers fruit-growing profitable in this section.

Other large fruit growers are Mr. A. L. Haights, south of Missouri Valley, with about twenty acres; Mr. W. A. Fouts, two miles north of Missouri Valley, who uses forty acres for fruit 
and vegetables, nearly one-half being in fruit; and Messrs. W. T. Worth and A. G. Worth of Raglan township, Harrison county, the former with more than fifty acres and the latter with eighty acres. In addition to apples, pears and peaches small fruits are grown successfully.

It has been amply demonstrated that fruit can be grown in this territory with profit, and with a judicious selection of shel$t \in$ red slopes and a more general planting of shelter-belts much land scarcely suitable for other purposes may thus be made profitable.

\section{Building Stone}

Building stone has been taken from the limited exposures of Missouri limestone between Logan and Woodbine, but none is quarried at present. The small area of these exposures, together with the growing use of cement blocks, make it improbable that the quarrying of this limestone will be resumed within the near future:

\section{Clays}

The loess elays of this territory, especially Harrison county, were formerly quite extensively employed in the manufacture of brick, and until quite recently yards were in operation in Misscuri Valley, Woodbine, Logan and Dunlap. At present only the Missouri Valley and Woodbine yards are in operation, and there has been a decided falling off in the total value of the product.

The Reports of the Iowa Geological Survey give the value of the clay products (common brick) in Harrison county for the respective years listed, as follows:

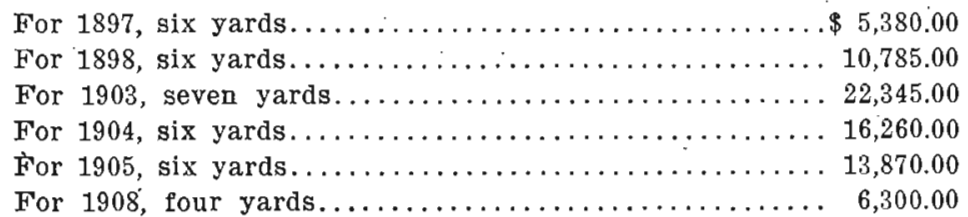

No bricks were burned in the Missouri Valley yards in 1909, and the Logan and perhaps other yards were transformed into cement block works. The latter industry has evidently been 
the cause of the decline of the former. Clay tile seems to have been entirely crowded out by cement tile.

\section{Sand and Gravel}

The widespread deposits of Aftonian sands and gravels furrish an abundant supply of these materials for building and other purposes. They are now extensively used for concrete work, building blocks and tiling, and cement works have, as noted, in large part taken the place of brickyards. The variation in the coarseness of the materials provides for all ordinary uses, and the thickness and extent of the beds insures an abundant supply, while their wide distribution places them within comparatively easy reach of all points within the territory.

Numerous small pits furnish supplies for local use, and some of them have been operated more or less irregularly for seven or cight years. The Cox pit, Peyton pit and Elliott pit are worked on the largest scale, and not only furnish the necessary sand for building purposes but each supplies a cement block and tile factcry. The great extent of the bottom-lands, now being tiled as a result of the establishment of a system of drainage ditches, makes the tile manufacturing industry of especial importance.

\section{Road Materials}

Few counties equal Harrison and Monona in the quality and abundance of road materials. The coarser gravels and the impure beds of the Aftonian in which silt, sand and gravel are mingled, are admirably adapted to such uses, and their wide distribution makes them available in all the territory within or ad. jacent to the uplands.

The loess bluffs and hills, together with the belts of exposed Kansan, furnish an abundance of material for building up roads across the lowlands, and the sand and gravel may be used for a top dressing.

\section{Water Supply}

The principal water supply for domestic and other uses is obtained on the bottom-lands from wells which reach the sands and gravels which underlie the alluvial plain. On the uplands 
this supply comes chiefly from the Aftonian beds which, resting on the impervious Nebraskan drift, form a reservoir usually containing an abundance of water. In all the well-sections already recorded which reached the Aftonian a generous supply of water was found in that formation. The fact that springs are numerous where the Aftonian crops out near the bases of the bluffs lias also been noted. Several well-sections have already been reported in connection with the Aftonian.

\section{Water Power and Drainage Ditches}

While the numerous larger streams have a sufficient fall and an adequate supply of water for the development of great waterpower, it is not probable that this will be utilized for some time to come, as the present tendency is toward the removal of dams and other obstructions from the streams to prevent interference with the great drainage projects. These drainage projects have been pushed forward at great expense, and they involve the changing of many miles of the channels of the principal tributaries of the Missouri river and the construction of many more miles of large drainage ditches. The principal changes and the main ditches are represented on the maps.

The Logan dam which supplied mill-power for many years was recently removed as an obstruction, and the Woodbine dam is the only one in our territory the use of which has been continued to the present time. The dam at Dunlap is not now utilized.

\section{METEOROLOGICAL RECORD}

It is a privilege to be permitted to present here a remarkable meteorological record furnished by Mr. Glenn H. Stern of Logan. The observations here recorded were commenced by Mr. Stern's grandfather, Mr. Jacob T. Stern, for the Smithsonian Institution and were continued to the time of his death. They were then taken up by lis widow who finally passed the work on to the grandson, who is now the official observer at Logan.

It is a unique and valuable record and should be preserved for future ready reference. 
TEMPERATURE AND RAINFALL AT LOGAN, IOWA.

From 1866 to 1909 .

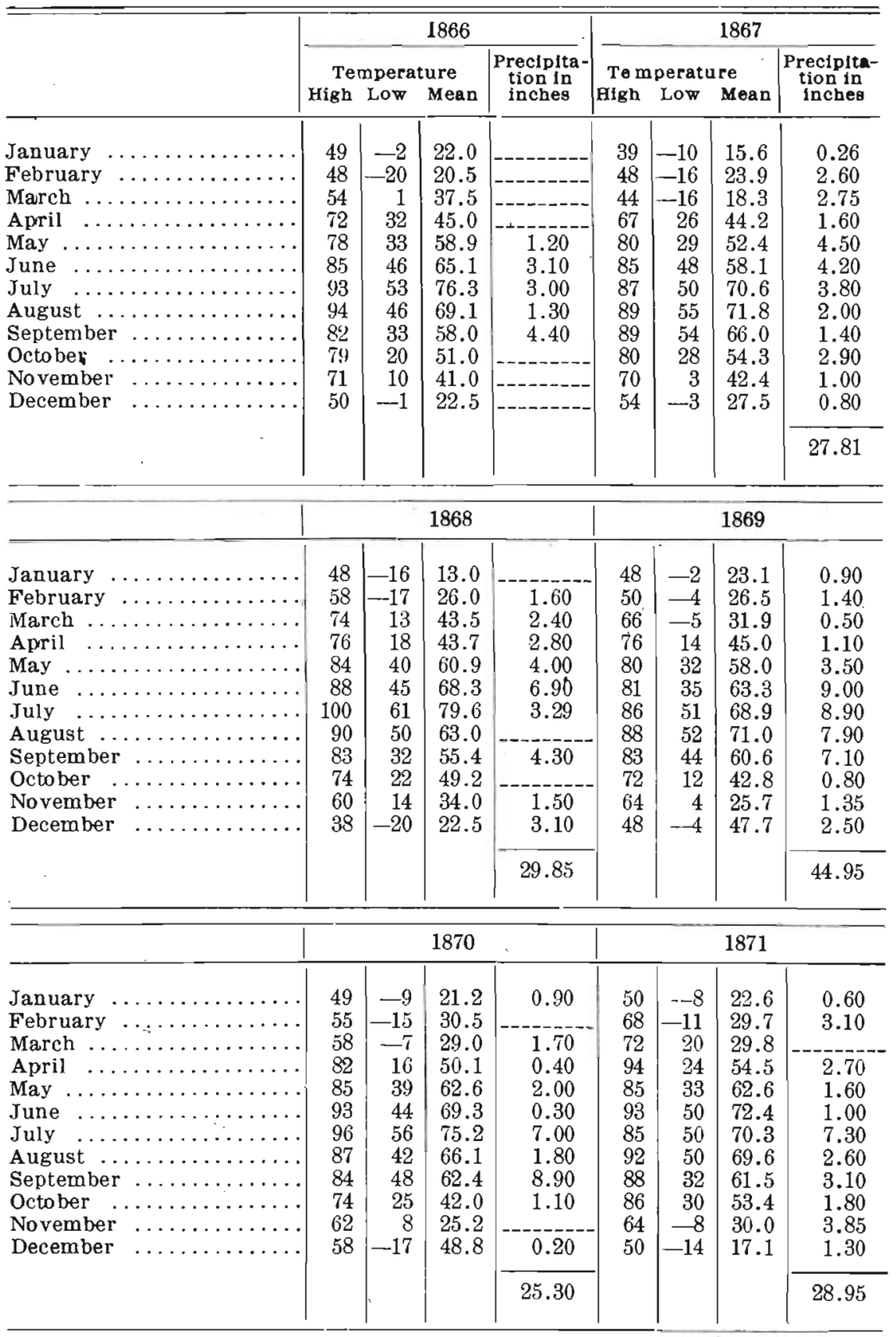


TEMPERATURE AND RAINFALL AT LOGAN, IOWA.

From 1866 to $190 y$.

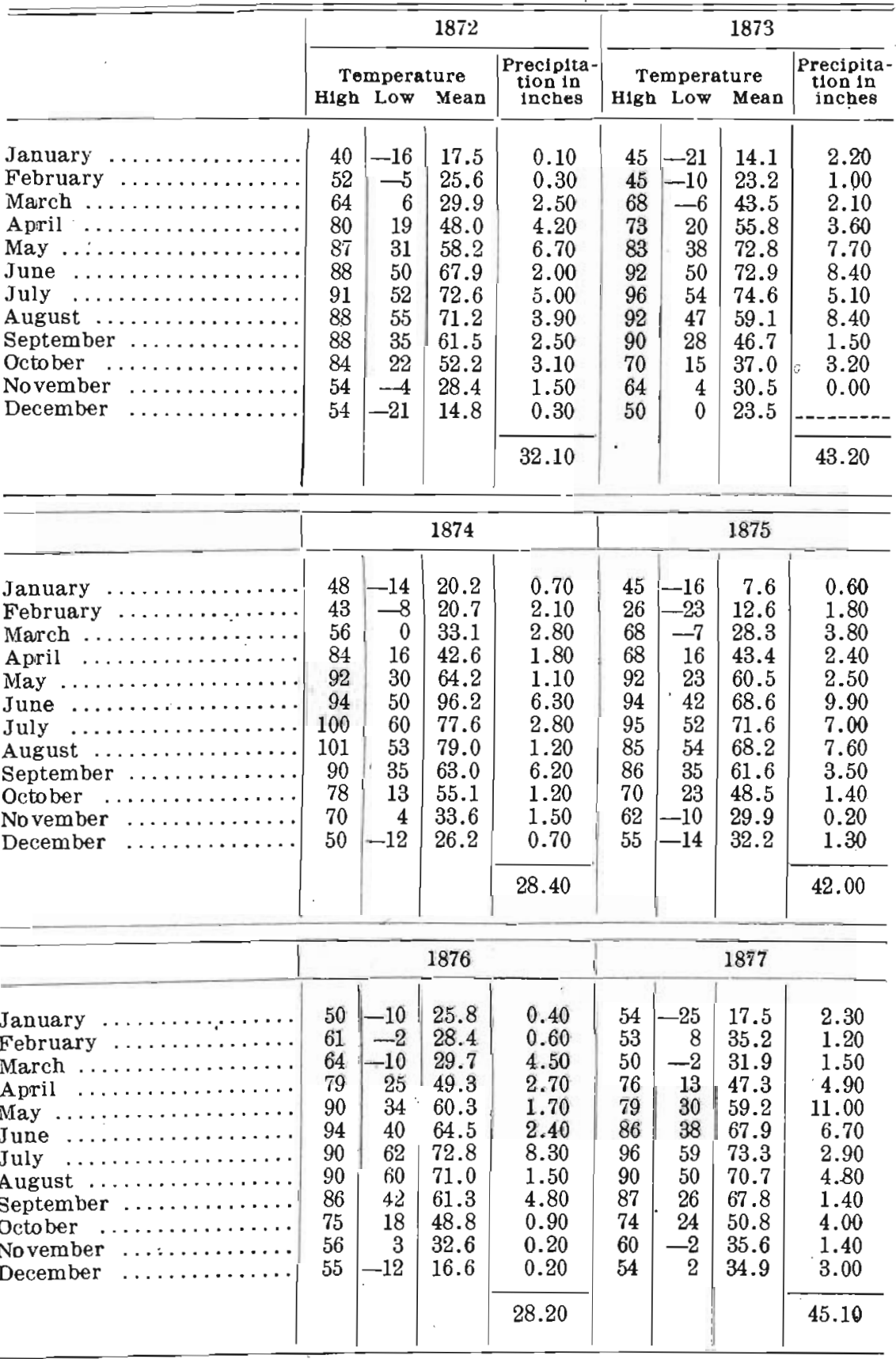


TEMPERATURE AND RAINFALL AT LOGAN, IOWA.

From 1866 to 1909 .

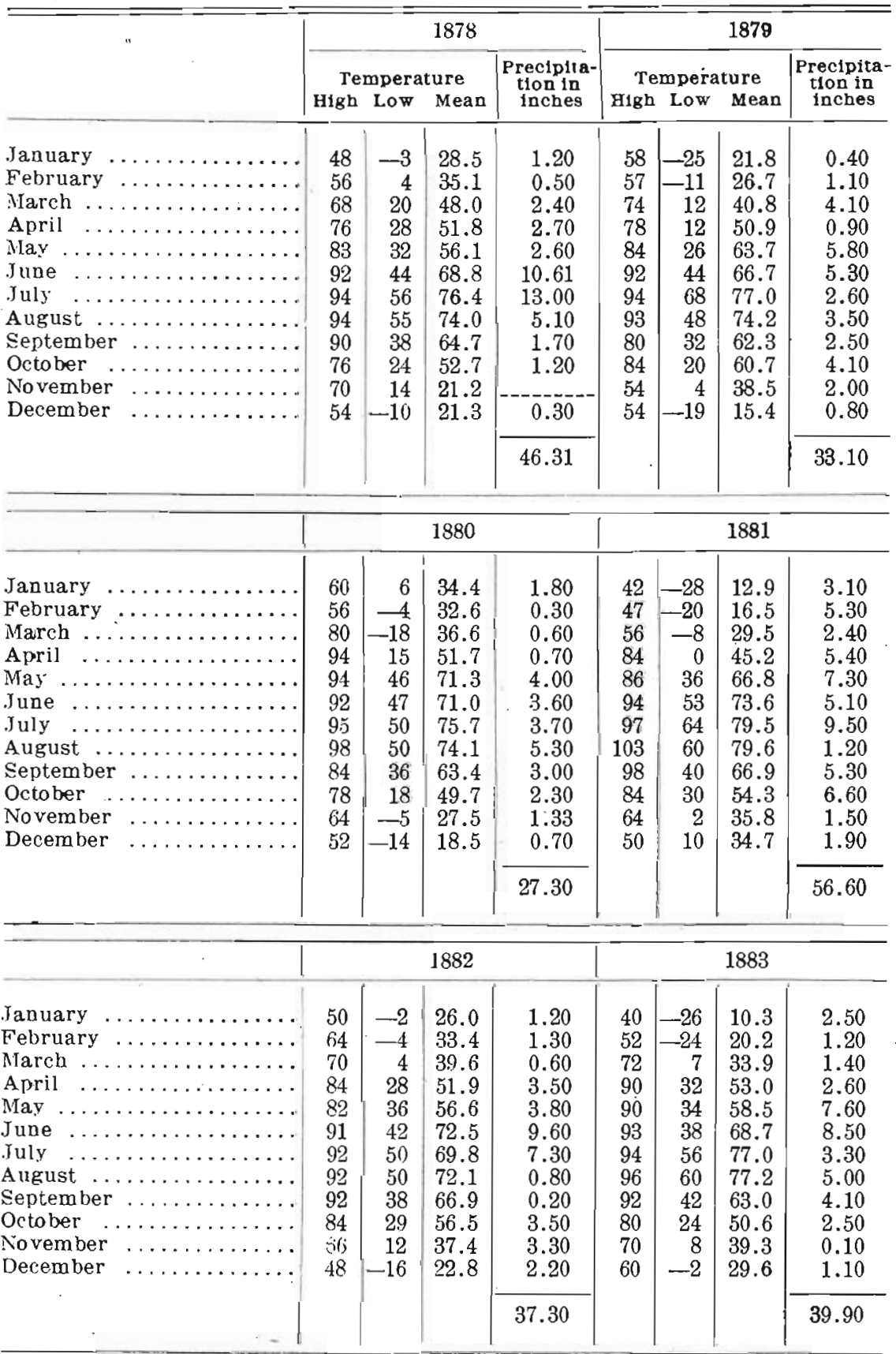


TEMPERATURE AND RALNFALL AT LOGAN, IOWA.

From 1866 to 1909.

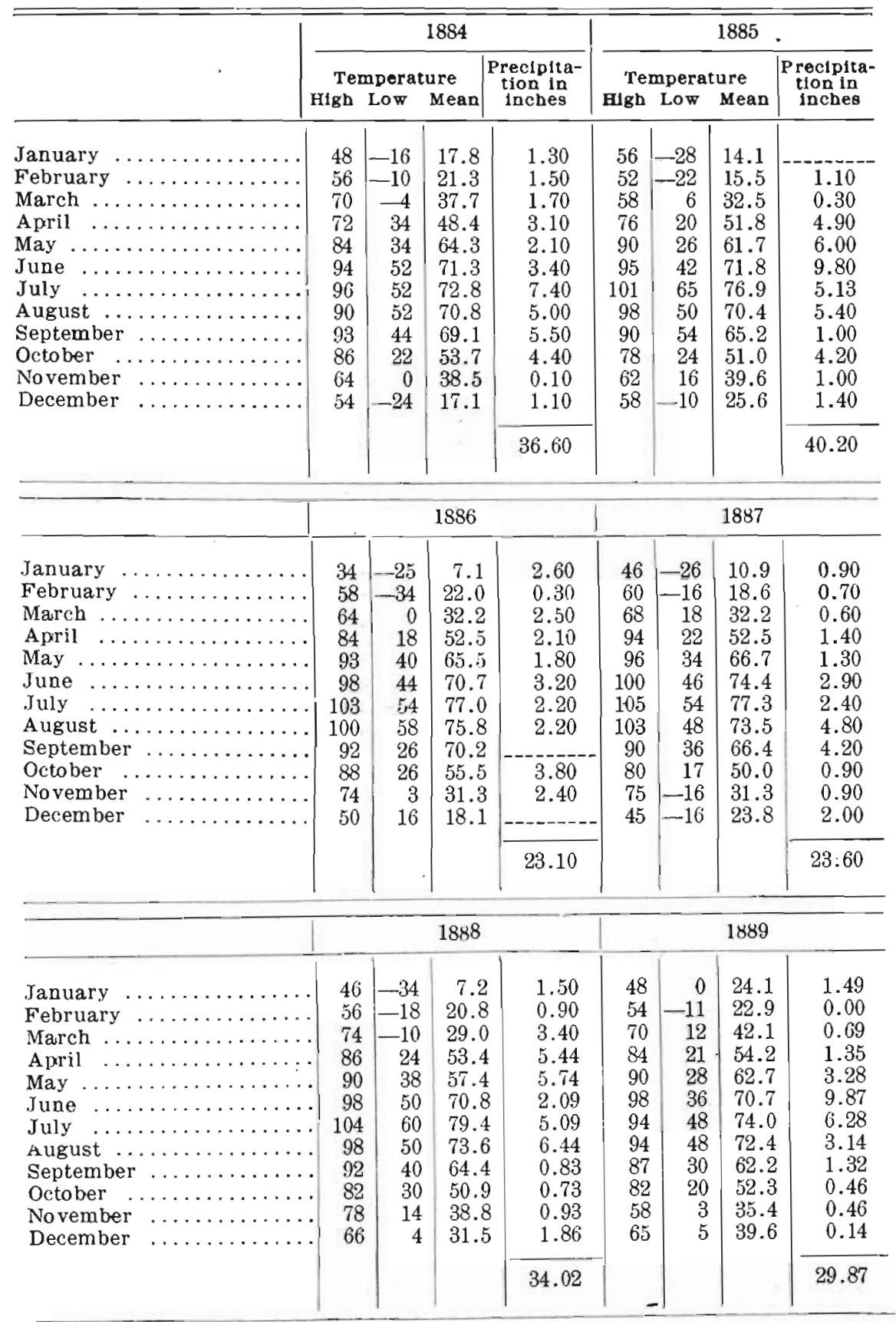


TEMPERATURE AND RAINFALL AT LOGAN, IOWA.

From 1866 to 1809 .

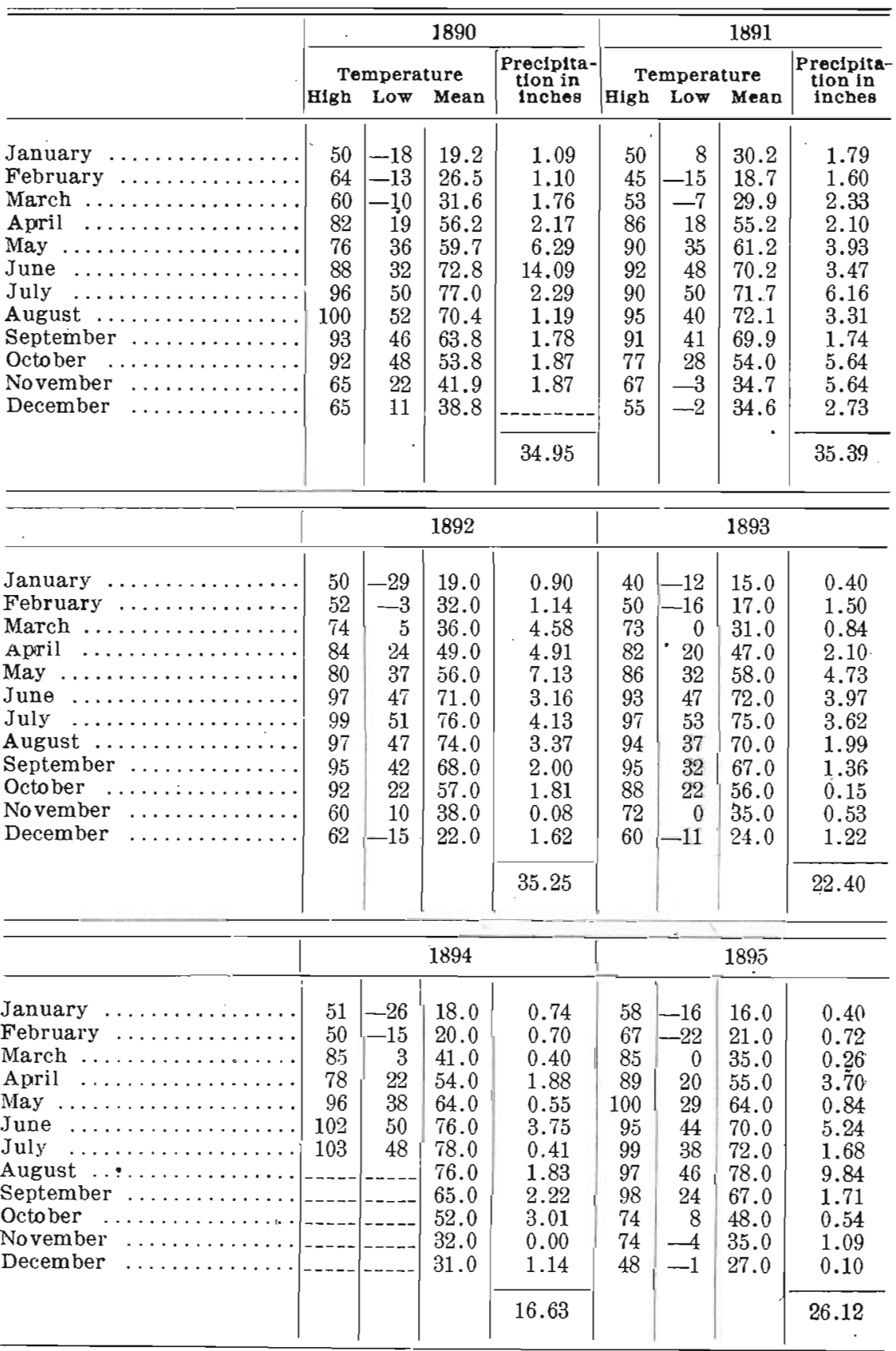


TEMPERATURE AND RAINFALL AT LOGAN, IOWA.

From 1866 to 1909.

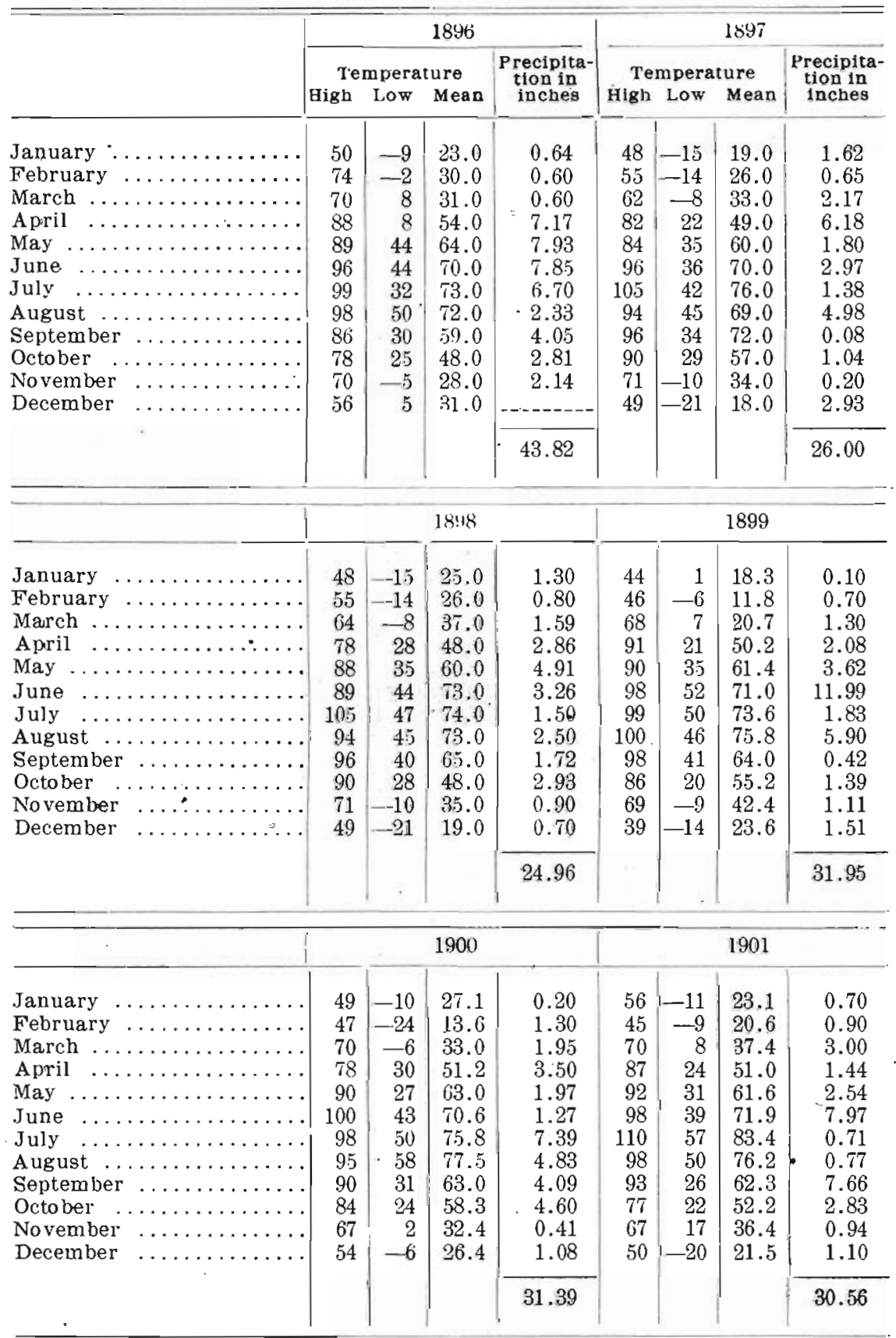


TEMPERATURE AND RAINFALL AT LOGAN, IOWA.

From $1866^{\circ}$ to 1909 .

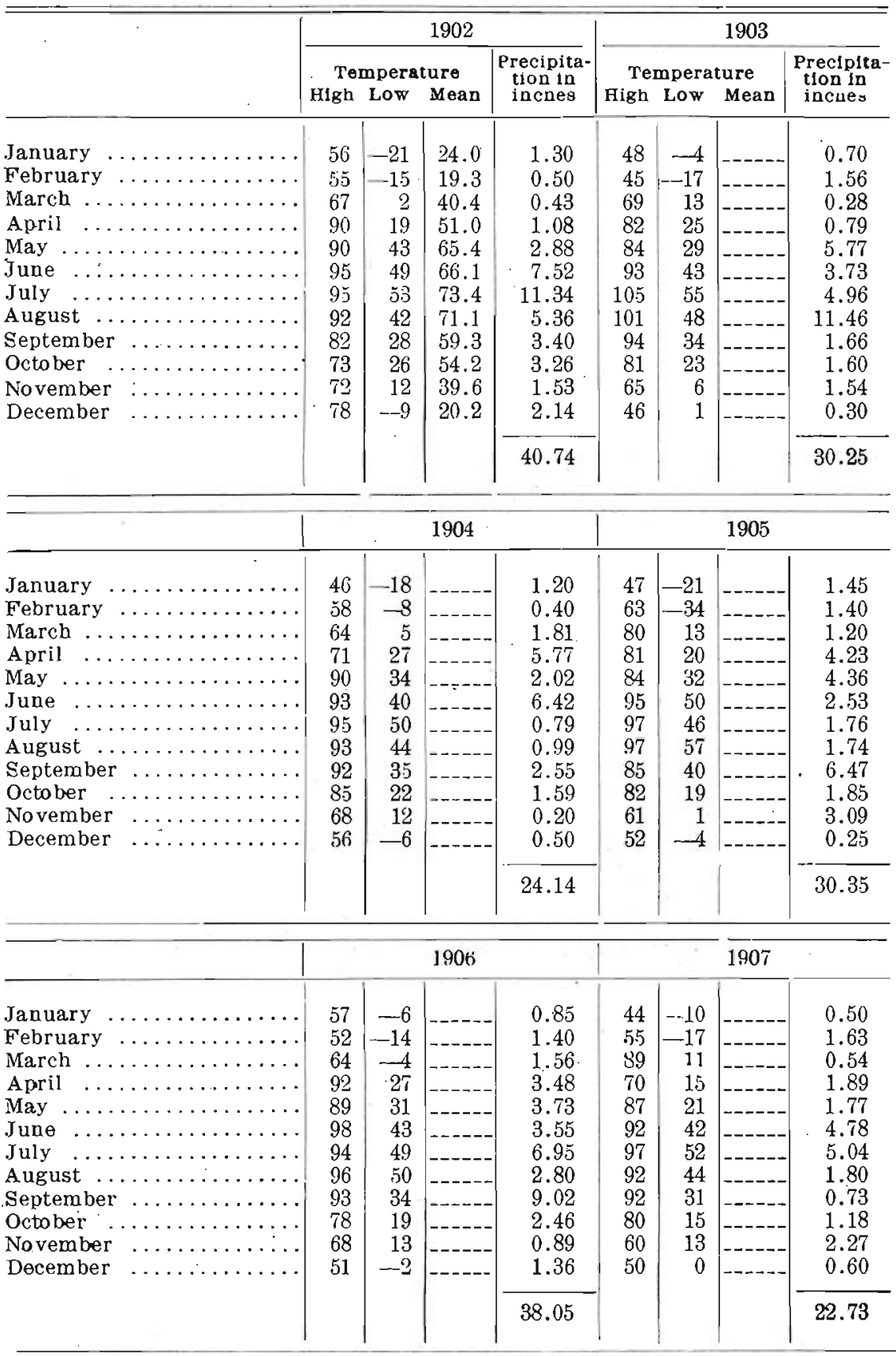


TEMPERATURE AND RAINFALL AT LOGAN, IOWA.

From 1866 to 1909.

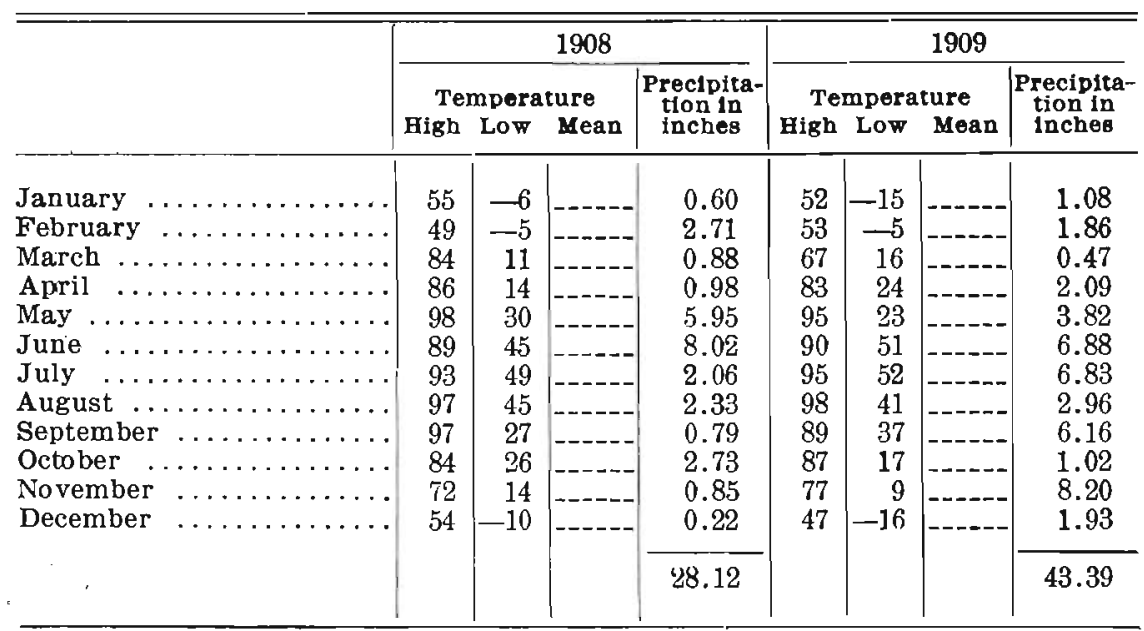

\section{BOTANICAL REPORT}

The botanical problems presented by Harrison and Monona counties are no less interesting than those which belong to the domain of geology. Moreover they are so intimately connected with some of the latter, and so deeply concern the welfare of the people of this part of the state that some discussion of them should find place in this report.

The most important of these problems concerns the possibility of the cultivation of trees and crops in our territory and this involves the question of the cause, or causes, of the treelessness of the prairies which form so large a part of the surface of these counties. Much light is thrown upon this problem by the study of the native flora, and a report upon this is accordingly included.

\section{The Prairies}

TYPES OF PRAIRIES

Few problems of the natural world have attracted as much attention as the cause of the treelessness of the prairies. Layman, amateur and scientific observers have wrestled with it, with the result that the literature of the subject is not only quite voluminous, but exceedingly variable in character and quality. 
The pioneers of Iowa found about seven-eighths of the state covered with prairie, but they sought the forested portions for their homes. This was true also of the pioneers of Harrison and Monona counties, for in these counties the first settlements were lacated in or near the larger groves.

This was done for several reasons: The forest offered building material and fuel so necessary to the home-builder; in it springs were abundant and furnished the indispensable water supply; it provided shelter from the blinding blizzards of the open country and was less likely to be invaded by the fire-fiend that periodically swept the prairies; and finally the pioneer had brought with him the belief that the soils of the forest were more fertile and that because trees did not grow on the prairies the latter would not produce crops.

But the prairie is no longer avoided. Improved methods of transportation and the modern use of artificial building materials have simplified the home-building problem; men no longer depend upon the surface supply of water; the extensive planting of shelter-belts, and the fencing of all lands have removed the horror if not the discomforts of the blizzard; the extensive cultivation of the prairie and the consequent better control of the surface vegetation has minimized the menace of prairie-fires; and man has found that his earlier prejudices against prairie soils were not well founded, that in fact forests grew on the poorest soils and that the rich prairie sustained a flora consisting largely of grasses which are related in structure and by habit to the ordinary cereals which constitute the great bulk of farm crops.

The fact is that the prairies as we knew them in Iowa have become a reminiscence. Their summer splendor and winter terrors have alike disappeared. Over their broad expanse no tinted waves of a varied flora sweep before the summer breeze. for countless acres of grain now cover their surface. The power of the biting blizzard has been largely broken by the groves and shelter-belts which everywhere give comfort and protection to countless happy, prosperous homes.

The prairies have changed, but the climatic causes which 
brought them about are still in existence, and their influence is largely antagonistic to man's interests and should be heeded.

We hear much during the cycles of moister seasons like that which has blessed our state now for several years, of the change in climate, the increase in rainfall, and the like, for in times of prosperity we easily forget adversity, and many of our people have forgotten the dry seasons which immediately preceded the present cycle of successful years, and which threatened to reduce our fair state to a desert condition. Only a few years ago crops failed for several seasons in succession over a considerable part of our state, and the larger lakes of the state were threatened by the drouth. But there has been no great change in climatic conditions and the net result of the influence of the good and evil conditions in a longer period of time is probably about the same.

In both their scientific and economic aspects the causes of the treelessness of the prairie are of so much interest and importance that they deserve serious consideration.

The prairies of Harrison and Monona counties present an inviting field for the study of the problem of their origin. More than nine-tenths of the area of Harrison county, and about eleven-twelfths of the area of Monona county were originally prairie, and large areas still retain their natural characteristics. The varied topography provides a variety of surface conditions, and the relatively large areas in which the forest and prairie come in contact make comparative studies of especial value and interest.

For these reasons the counties here discussed were selected in part as types of a larger area, and in part for special local studies on the cause of the treelessness of the prairies.

Among scientific observers the problem of the prairie has usually been assigned to, or assumed by the geologists, and Dana, Whitney, White, Alexander Winchell, N. H. Winchell, Foster, Newberry, D. D. Owen, Shaler, Upham, Worthen and other well-known geologists wrestled with it with varying success. White specifically states* that the "question of the origin of the prairie has become more hackneyed perhans. than any other

* Report on the Geological Survey of Iowa, vol. I, p. 132, 1870. 
of the speculative questions which North American geology affords," and Willard says* "their explanation belongs to the science of Landscape Geology."

Yet the problem is one which belongs in its most striking aspects to plant ecology and falls properly within the province of the botanist, for no matter what may be the variation in the surface characteristics of the prairies there is comparative uniformity in the nature of their floral covering. Not only are prairies striking because of the absence of trees, but they are marked none the less definitely by the presence of a flora which is wholly distinct from the smaller (chiefly herbaceous) flora of the forest.

The areas which were originally covered with a prairie flora in Iowa are of six more or less distinct types:

1. The broad flat plains which characterized the Wisconsin and Iowan drift areas and a part of the un-eroded Kansan drift area such as may be observed in Osceola county and southward. These plains contained large undrained areas the swamps, ponds and lakes of which possessed a rich hydrophytic flora.

2. The more rolling drift surfaces such as are presented by the greater part of the Kansan area and the more or less distinct moraines bordering the Wisconsin and Iowa areas. $\dagger$ In our territory the drift is almost everywhere covered with loess.

3. The very rough loess ridges which border the Missouri valley and which present the most extreme xerophytic conditions in Iowa.

4. The well-drained alluvial plains such as are shown at their best along the Missouri, but which are more or less developed along all the larger streams. The undrained portions of these plains are, of course, hydrophytic.

5. The prairie ridges which appear in all the forested rougher parts of the state, but are most striking in the more heavily timbered eastern parts where they have been known as "oak openings" because the surrounding forest usually consists of the hardier oaks and because some of these oaks are

* Willard, Daniel E., The Story of the Prairies, p. 21, 1903.

iFor the distribution of the drift areas in Iowa see map plate III, Report of Iowa Geological Survey, vol. XIV, 1904. 
sparsely seattered over them. These prairie openings are sometimes mere tongues of greater prairie areas which extend into the forest, but they are frequently completely surrounded by forest and may be several miles from larger prairie tracts. They vary in area down to a few square rods and are developed independently of geological formations except in so far as these determine topography.

6. The sand-dune areas. (See figures 35 and 36.) These are usually considered distinct from the prairie but a comparison of the floras shows that they differ but little.

All but the first of these types are represented in Harrison and Monona counties, though the sixtl, including the prairieopenings, so blends with the general prairie that it does not here appear in its most striking detached condition.

These several types of prairie areas present a variety of topographic conditions and they are found upon all the types of geologic formations which come to the surface not only in these counties but in the state at large.

They agree only in two particulars, but these so important that they determine the character of the prairie. The one is the prairie flora which is strikingly uniform on the several types of prairie areas; and the other is exposure to certain climatic influences which are herein more fully discussed.

THE PRAIRIE FLORA.

The general character of the prairie flora is shown in the accompanying table. Specimens were collected at the localities marked (+) and are now in the herbarium of the State University of Iowa. . Those marked $\mathrm{P}$ were reported by Professor Pammel in the Proceedings of the Iowa Academy of Science, vol. III, 1896, pp. 106-135, and were not found by the writer.

Of the several localities given in the table Missouri Valley, Blair bridge, Logan, Woodbine and Murray hill are in Harrison county and Ute, Grant Center, Mapleton and Onawa are in Monona county.

The species marked in the first column were collected on the Joess ridges in the northern part of Missouri Valley in exposed places, chiefly near stations (1) and (3) described in connection 
with the notes on evaporation, and shown in plate XXXIII, figure 1, plate XXXVIII, figure 1, and plate XXXIX, figure 1.

Those marked in the second column were collected on the better drained portion of the alluvial plain between Missouri Valley and California Junction.

The third column includes the species collected on the sanddunes near the Blair railway bridge west of California Junction. A portion of this dune area is shown in figures 35 and 36 .

The fourth column contains species which were collected on a bit of original prairie in the cemetery grounds at Logan, in loess-Kansan territory. This area lies on the front of the Logan bench, the slope facing east.

The fifth and sixth columns contain lists of the species collected on Murray hill, the first on the upper or loess part of the ridge illustrated in plate XXI, figure 1, and the second on the lower Aftonian surfaces. The intermediate Kansan and Loveland, occupying the vicinity of the basal part of the most abrupt upper portion of the hill showed exactly the same flora as that of the Aftonian, but most of the plants were more vigorous than those of the gravelly Aftonian surfaces. The difference between the two columns is evidently due to the fact that the loess area was a little more exposed than a part of the Aftonian surface. The most exposed parts of the latter yielded the same flora as that which was found on the loess ridge.

The seventh column contains the record of the species reported by Professor L. H. Pammel* from the Woodbine bluffs. The writer found the same species in the vicinity of Woodbine, but Corydalis aurea var. occidentalis, Hypoxis hirsuta, Lactuca pulchella and Silene antirrhina were observed only along the railway and not on the hills.

The Ute column contains plants collected in part by Mr. Boot and in part by the writer on an inland rolling loess-Kansan prairie area northwest of Ute.

At Grant Center the exposed slopes showed Aftonian in the lower part and loess in the upper part. The plants here listed were collected only on the western slope of the detached ridge lying south of the Chicago, Milwaukee and St. Paul railway, 
except those marked $O$ in the loess column which were collected on other loess ridges and slopes near Grant Center.

The Mapleton plants were collected on the rolling loessKansan areas chiefly southeast and northwest of Mapleton.

The Turin plants were collected on the loess ridges north of Turin, illustrated in plate XXIII, figure 2. The more or less broken ridge, or series of ridges, extends in a somewhat southwesterly direction, and the surfaces are very xerophytic.

The Onawa collections were made on the alluvial prairie east of Onawa.

Many of the species were found practically in all the areas listed, but where specimens were not collected the species is not checked.

With the exception of a few species which belong to the flora of the dry western plains the species in the following list are, or were, more or less common on ali types of prairie represented in the state. Agoseris cuspidata, Anemone patens var. Wolfgangiana; Astragalus caryocarpus, Lithospermum angustifolium and Psoralea esculenta were formerly very widely distributed, but they are becoming noticeably more and more restricted in distribution, and have disappeared from a large part of the state.

The following species belong to the western plains flora:

Aplopappus spinulosus
Astragalus lotiflorus
Astragalus plattensis
Bouteloua hirsuta
Castilleja sessitiflora
Ceanothus ovatus var. pubescens

Lygodesmia rostrata

Oxytropis Lamberti

Pentstemon gracilis

Pentstemon grandiflorus

Yucca glauca.

The Boutelona, Ceanothus, and both species of Pentstemon are also found on the sand-mound in Muscatine and Louisa counties in eastern Iowa. The remaining species are found only in the western part of the state.

The plants in the prairie list which are marked with an asterisk have been introduced, but are now more or less established on the prairies.

Some of the species are found more commonly on somewhat lower or more sheltered grounds and only exceptionally occur in dry places. Such are Amphicarpa Pitcheri, Anemone. 
canadensis, Erigeron philadelphicum, Helianthus strumosus var. mollis, Ranunculus abortivus, Salix longifolia, Silene stellata, Smilacina stellata, Teucrium canadense and Carex gravida.

Cenchrus carolinianus and Cycloloma atriplicifolia are usually found in sand but in western Iowa both occur upon the loess hills. On the other hand Crotalaria sagittalis, Desmodium canadense, Desmodium canescens and Hedeoma hispida were found only in the sandy areas of Harrison county but in other parts of the state they are also found upon dry prairie.

Cyperus Schweinitzii, Paspalum ciliatifolium and Strophostyles helvola are found only in sandy places.

\section{PLANTS OF DRY PRAIRIES}
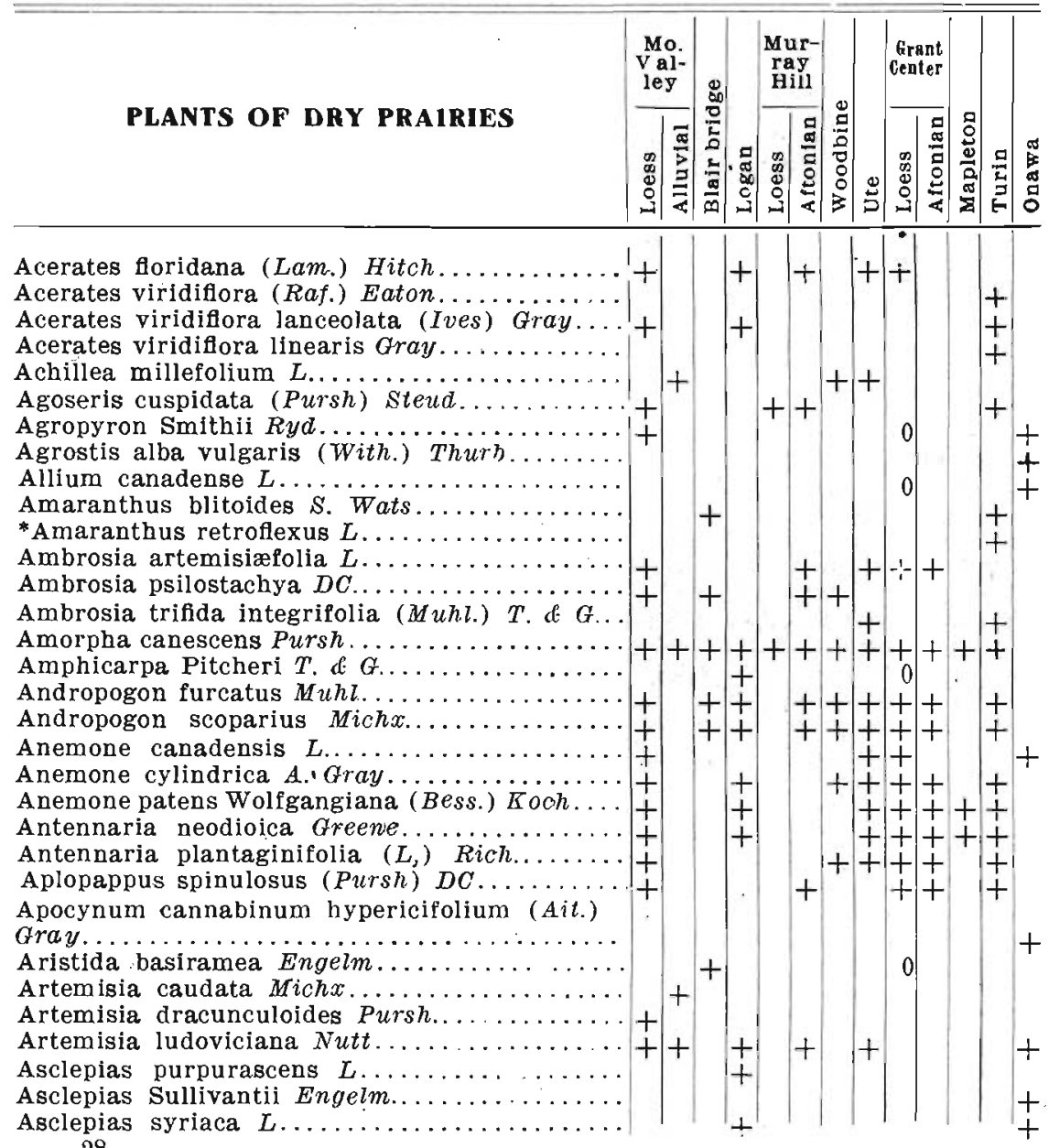
PLANTS OF DRY PRAIRIES

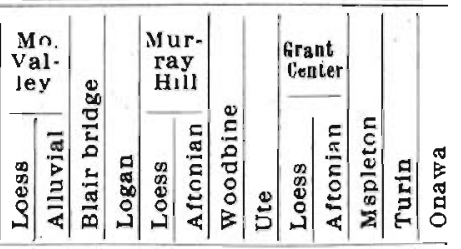

Asclepias tuberosa $L$

Asclepias verticillata $L \ldots \ldots \ldots \ldots \ldots \ldots \ldots \ldots \ldots \ldots \ldots+$

*Asparagus officinalis $L \ldots \ldots \ldots \ldots \ldots \ldots \ldots$

Aster lævis $L \ldots \ldots \ldots \ldots \ldots \ldots \ldots \ldots \ldots \ldots \ldots \ldots$

Aster multiflorus exiguus Fermald..........

Aster novæ-angliæ $L \ldots \ldots \ldots \ldots \ldots \ldots \ldots \ldots \ldots \ldots \ldots \ldots \ldots \ldots \ldots$

Aster oblongifolius $N u t t \ldots \ldots \ldots \ldots \ldots \ldots \ldots+$

Aster sericeus Vent..................

Astragalus canadensis $L \ldots \ldots \ldots \ldots \ldots \ldots \ldots$

Astragalus caryocarpus $k c \ldots \ldots \ldots \ldots \ldots \ldots \ldots+$

Astragalus lotiflorus $H o o k \ldots \ldots \ldots \ldots \ldots \ldots \ldots$

Astragalus plattensis Nutt.

Baptisia leucantha $T$. \& $G$.

a curtipendula (Mirhn.) Torr.........

* Rlassica a

* Brassica nigra (L.) Koch................

Brauneria angustifolia $(D C$.$) Heller.........$

Cacalia suaveolens $L$. .

Cacalia tuberosa Nutt.

(1)

Cannabis sativa $L \ldots \ldots \ldots \ldots \ldots \ldots \ldots$

Capsella bursa-pastoris (L.) Medir.........+

Carex festucacea $s c h k \ldots \ldots \ldots \ldots \ldots \ldots \ldots \ldots \ldots++$

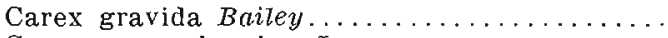

Carex pennsylvanica $\operatorname{Lam} \ldots \ldots \ldots \ldots \ldots \ldots \ldots$

Cassia chamæcrista $L \ldots \ldots \ldots \ldots \ldots \ldots \ldots \ldots$

Castilleja sessiliflora Pursh..............

Ceanothus americanus $L \ldots \ldots \ldots \ldots \ldots \ldots \ldots$

Ceanothus ovatus pubescens $T$. \& $G \ldots \ldots \ldots \ldots+$

Cenchrus carolinianus Walt.............+

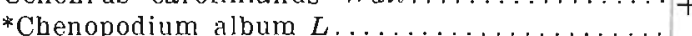

Chrysopsis villosa (Pursh) Nutt...........

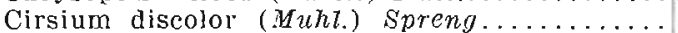

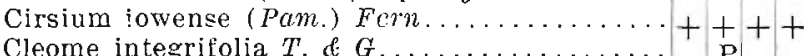

Comandra Richardsoniana Fern...........

Comandra umbellata $(L$.$) Nutt.............$

Convolvulus sepium $t \ldots \ldots \ldots \ldots \ldots \ldots \ldots \ldots \ldots$

Coreopsis palmata $N u t t \ldots \ldots \ldots \ldots \ldots \ldots \ldots$

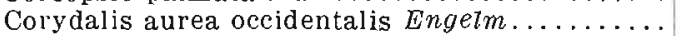

Crotalaria sagittalis $L \ldots \ldots \ldots \ldots \ldots \ldots \ldots \ldots$

Cycloloma atriplicifolium (spreng.) Coult.

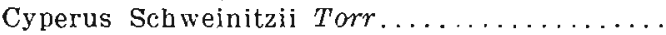

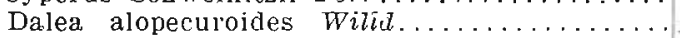

Dalea enneandra $N u t t \ldots \ldots \ldots \ldots \ldots \ldots \ldots$

Delphinium Penardi $H u t h \ldots \ldots \ldots \ldots \ldots \ldots \ldots$

Desmanthus illinoensis (Michx) irick......

Desmodium canadense $(L) D$.$C .$

Desmodium canescens $(L) \quad D. C . . \ldots \ldots \ldots \ldots \ldots$

Desmodium paniculatum pubens $T$. \& $G \ldots \ldots \ldots$

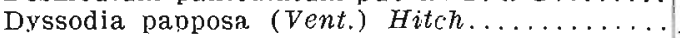

Ellisia nyctelea $L \ldots \ldots \ldots \ldots \ldots \ldots \ldots \ldots \ldots$

Elymus canadensis $L \ldots \ldots \ldots \ldots \ldots \ldots \ldots \ldots$

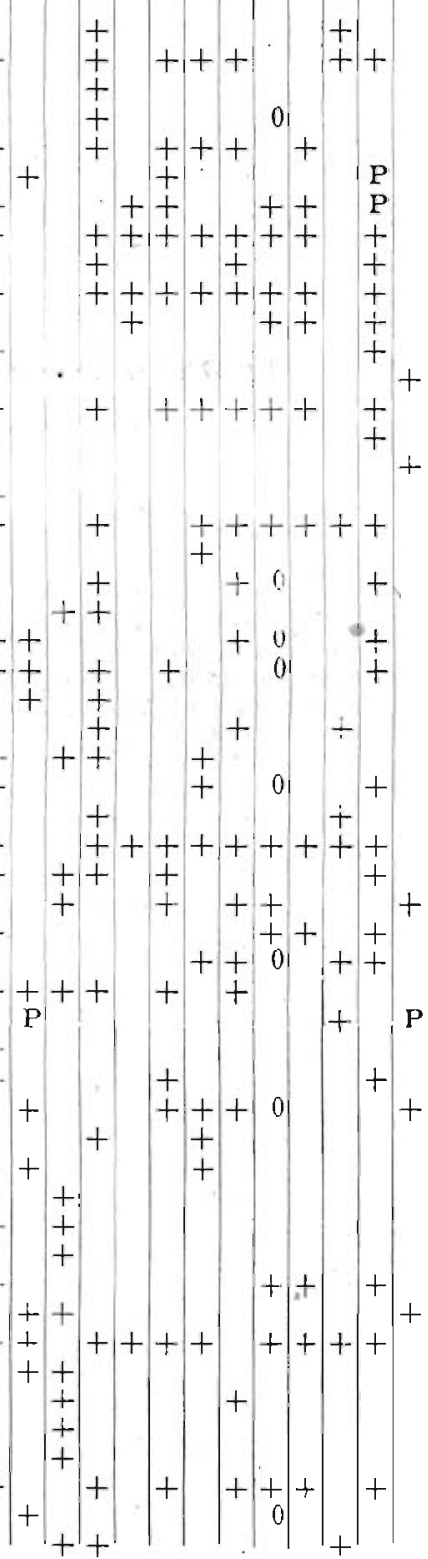


PLANTS OF DRY PRAIRIES

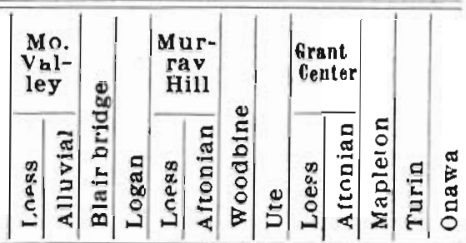

*Equisetum arvense $L$

Equisetum hyemale $L$.

Equisetum hyemale intermediun $A$. A. Eaton

Equisetum lævigatum $A . B r \ldots \ldots \ldots \ldots \ldots$

*Eragrostis megastachya (Koel.) Link.......

Erigeron canadense $L \ldots \ldots \ldots \ldots \ldots \ldots \ldots \ldots$

Erigeron philadelphicum $L \ldots \ldots \ldots \ldots \ldots \ldots \ldots$

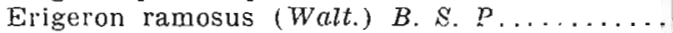

Eupatorium altissimum $L \ldots \ldots \ldots \ldots \ldots \ldots \ldots$

Euphorbia corollata $L \ldots \ldots \ldots \ldots \ldots \ldots \ldots \ldots$

Euphorbia glyptosperma Engelm...........

Euphorbia maculata $L \ldots \ldots \ldots \ldots \ldots \ldots \ldots \ldots+$

Euphorbia marginata Pursh............

Euphorbia Preslì Guss................

Euphorbia serpens $H . B . K \ldots \ldots \ldots \ldots \ldots \ldots$ P

Euphorbia serpyllitolia Pers............

Festuca octoflora Walt...............

Fragaria virginiana Duchesne...............

Gaura coccinea Pursh................

Gaura parviflora Dougl.................. $\mathrm{P}$

Gerardia aspera Dougl...............t+

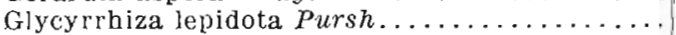

Grindelia squarrosa (Pursh) Dunal.........

Hedeoma hispida Pursh..................

Helianthemum canadense $(L.) \operatorname{Mrch} x \ldots \ldots \ldots$.

Helianthus anduus $L \ldots \ldots \ldots \ldots \ldots \ldots \ldots \ldots$

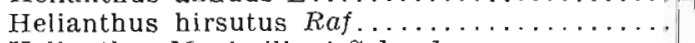

Helianthus Maximiliani Schrad.

Helianthus scaberrimus $L \ldots \ldots \ldots \ldots \ldots \ldots \ldots \ldots+$ Helianthus strumosus var. mollis $T$ \& $G \ldots \ldots .+$

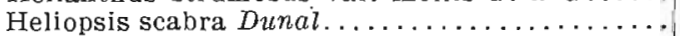

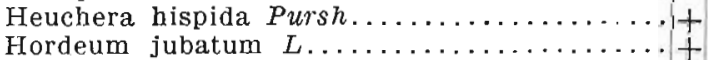

Houstonia angustifolia Mich $x \ldots \ldots \ldots \ldots \ldots+$

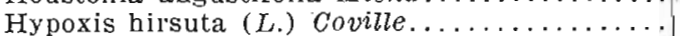

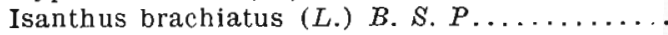

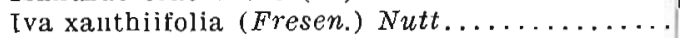

Kœleria cristata $(L$.$) Pers...............$

Kuhnia eupatoroides var. corymbulosa $T$. $G$. .

Lactuca canadensis $L \ldots \ldots \ldots \ldots \ldots \ldots \ldots \ldots$

Lactuca ludoviciana (Nutt.) Rid...........

Lactuca pulchella (Pursh) $D C . . . \ldots \ldots \ldots$

Lactuca sagittifolia $E l\rceil \ldots \ldots \ldots \ldots \ldots \ldots \ldots$

*Lactuca scariola $L \ldots \ldots \ldots \ldots \ldots \ldots \ldots \ldots \ldots \ldots$

Lappula Redowskii var. occidentalis (Wats.)

Ryd.

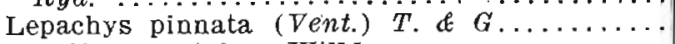

Lepidium apetalum Willd...............

Lespedeza capitata Michx...............

Liatris punctata $H K$.

Liatris scariosa Willd.................

Liatris squarrosa Willd.

Linum sulcatum Riddell.

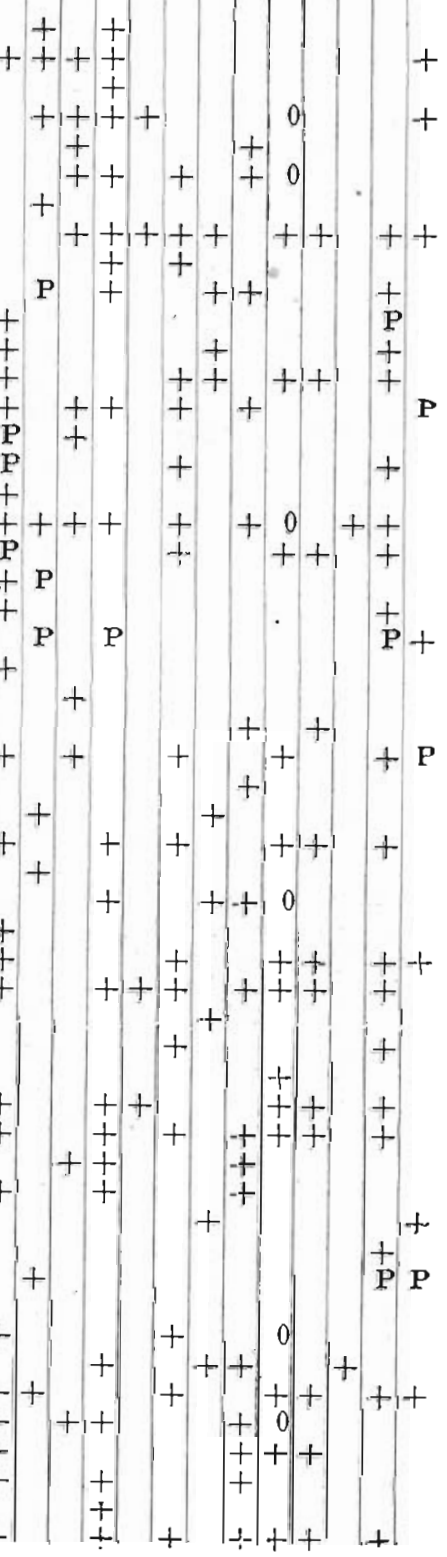




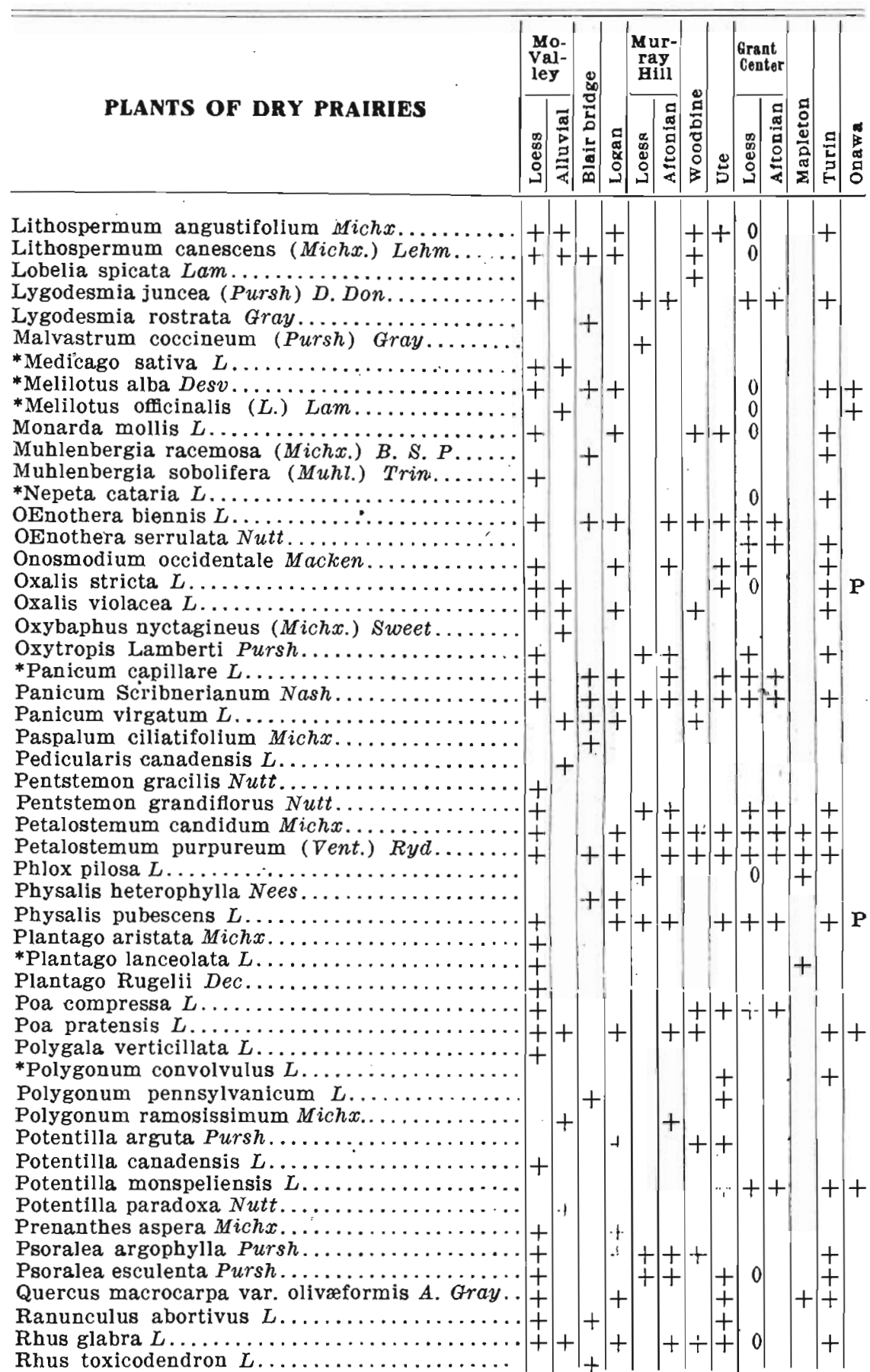




PLANTS OF DRY PRAIRIES

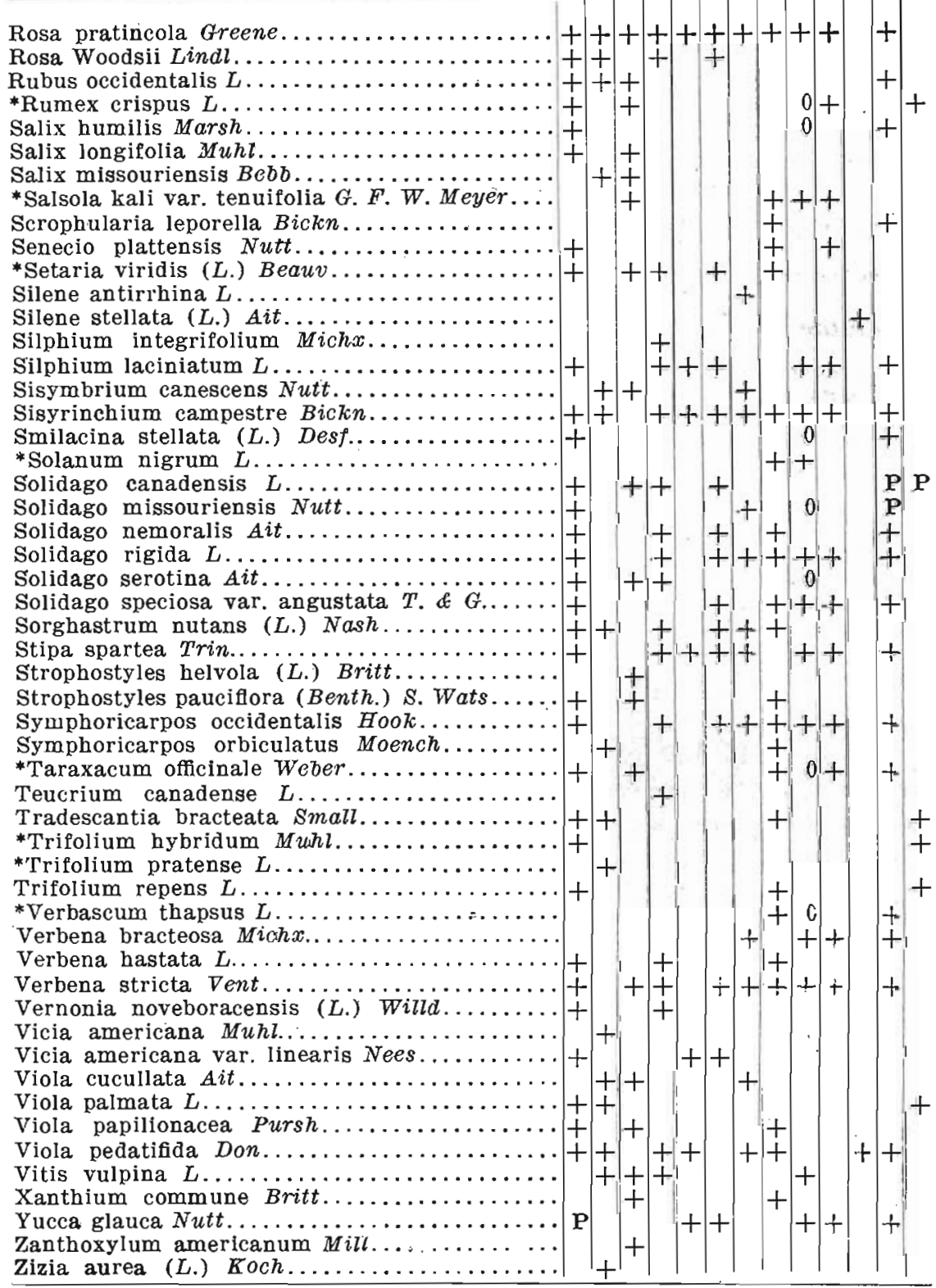


In addition to the species included in the list the following forms were found on dry prairie or sand-dune surfaces at the localities cited:

At Blair bridge on sand-dunes:

* Digitaria humifusa Pers.

Eragrostis pilosa (L.) Beauv.

Euphorbia dentata Michx.

At Pisgah, on dry banks:

Carex gravida Bailey.

Lithospermum canescens (Mickx.)

Lehm.

Rosa pratincola Greene.

At Orson, on dry banks:

Agropyron Smithii Ryd.
* Panicum huachucae var. silvicola Hitch. \& Chase.

Silene antirrhina $\mathrm{L}$

Vicia americana Muhl.

Zizia aurea (L.) Kocb.

Pammel (loc. cit.) reports the following:

Aster ericoides I. Turin.

Aster sagittifolius Wedem. Turin.

Euphorbia Geyeri Engelm. Missouri

Valley.

Euphorbia hexagona Nutt. Missouri

Valley.

Helianthus Maximiliani Sehrad. Whiting.

Martynia proboscidea Glox. Missouri Valley.

Woodbine bluff flora, reported by Pammel (loc. cit.).

Erigeron annuus (L.) Pers.

* Rumex acetosella $\mathbf{L}$.

Euphorbia dictyosperma F. \& M.

Sporobolus cuspidatus (Torr.) Wood.

Polytaenia Nuttallii DC.

Pammel also reports Elymus robustus $\mathrm{S}$. \& $\mathrm{S}$. from the Boyer valley.

This flora of the prairies possesses the ordinary xerophytic characters to a greater or lesser degree. Many of the species have small tops and relatively large roots; some are hairy, scaly or even spiny; cutin and other hard protective structures are developed; poisonous or disagreeable properties are sometimes found; and the stomata are sunken or otherwise protected.

In order that the contrast between the prairie flora and that of other habitats may be brought out more prominently lists of plants which were collected in Harrison and Monona counties in upland and alluvial woods and in swamps, etc., are added. For convenience in making comparisons all the lists are alphabetical. 


\section{PLANTS OF UPLAND WOODS}

Actinomeris alternifolia (L.) DC. Calhoun.

Adiantum pedatum L. Maidenhair Fern. Grant Center.

Agrimonia mollis T. \& G. Ute, Grant Center.

Agrostis perennans (Walt.) Tuck. Thin-grass. 'Ute.

Allium tricoccum Ait. Leek. Ute.

Amelanchier canadensis (L.) Medic. June-berry. Calhoun.

Amphicarpa Pitcheri T. \& G. East of Missouri Valley, Ute.

Apios tuberosa Mœnch. Ute.

Aquilegia canadensis L. Columbine. Missouri Valley, Pisgah, Calhoun, Ute, Grant Center.

Arabis canadensis L. Missouri Valley.

Arabis dentata T. \& G. Missouri Valley.

Arisaema triphyllum (L.) Schott. Indian Turnip. Calhoun, Ute, Grant Center.

Aster cordifolius L. Ute.

Botrychium virginianum (L.) Sw. Calhoun.

Campanula americana L. East of Missouri Valley, Missouri Valley, Ute.

Carex Davisii Schwein. Calhoun.

Carex gravida Bailey. Calhoun.

Carex grisea var. angustifolia Boott. Ute.

Carex laxiflora Lam. Missouri Valley.

Carex laxiflora var. blanda (Desv.) Boott. Calhoun, Ute, Grant Center.

Carex rosea Schk. Missouri Valley, Ute, Grant Center:

Carex scirpoides Schk, Ute.

Carex sparganioides Muhl. Calhoun.

Carya glabra var. villosa (Sarg.) Rob. Pig-nut Hickory. Calhoun, Missouri Valley, Turin, Ute.

Celastrus scandens L. Bittersweet. Pisgah, Ute.

Celtis occidentalis var. crassifolia (Lam.) Gray. Hackberry. Grant Center, Missouri Valley, Ute.

Chenopodium hybridum L. Turin, Onawa, Missouri Valley.

Circaea lutetiana L. Enchanter's Nightshade. Ute.

Cirsium altissimum (L.) Spreng. Tall Thistle, Pisgah, Ute, Grant Center.

Cornus asperifolia Michx. Dog-wood. Logan.

Cornus paniculata L'Her, Dog-wood. Ute, Grant Center.

Cornus stolonifera Michx. Red Osier. Calhoun, Ute.

Corylus americana Walt. Hazel. Missouri Valley, Ute.

Cratatgus mollis (T. \& G.) Scheele. Red Haw. Turin, Missouri Valley, Grant, Center, Ute.

Cryptotaenia canadensis (L.) DC. Ute, Grant Center.

Cynoglossum officinale L. Calhoun.

Cystopteris fragilis (L.) Bernh. Bladder-fern. Missouri Valley, Grant Center. Delphinium tricorne Michx. Larkspur. Ute.

Dentaria laciniata Muhl. Turin.

Desmodium Dillenii Darl. Beggar-ticks. Ute.

Desmodium gradiflorum. (Walt.) DC. Beggar's-ticks. Calhoun, Ute.

Dicentra cucullaria (L.) Bernh. Dutchman's Breeches. Turin, Missouri Valley, Ute. 
Ellisia nyctelea L. Turin, Missouri Valley, Grant Center.

Elymus striatus Willd. Wild Rye. Missouri Vailey, Ute.

Equisetum hyemale var. robustum (A. Br.) A. A. Eaton. Scouring Rush. Magnolia.

Equisetum laevigatum A. Br. Scouring Rush. Missouri Valley.

Erigeron philadelphicus L. Fleabane. Calhoun, Grant Center.

Erigeron pulchellus Michx. Daisy. Missouri Valley.

Erythronium albidum Nutt. Dog's-tooth Violet. Turin, Ute.

Evonymus atropurpureus Jacq. Wahoo. Ute, Grant Center.

Eupatorium purpureum L. Purple Boneset. Ute.

Eupatorium urticaefolium Reich. White Snake-root. East of Missouri Valley, Ute.

Festuca nutans Willd. Missouri Valley, Pisgah, Calhoun.

Fragaria vesca var. amcricana Porter. Ute.

Fragaria virginiana Duches. Wild Strawberry. Missouri Valley, Calhoun, Ute, Grant Center.

Fraxinus pennsylvanica Marsh. Green Ash. Missouri Valley, Ute, Grant Center.

Galium aparine L. Bed-straw. Turin, Missouri Valley, Calhoun, Ute, Grant Center.

Galium circaezans Michx. Calboun.

Galium triflorum Michx. Sweet-scented Bed-straw. Ute.

Geum virginianum L. Ute, Logan, Grant Center.

Glyceria nervata Willd. Manna Grass. Turin.

Gymnocladus dioicus (L.) Koch. Kentucky Coffee-bean. ' Missouri Valley, Grant Center.

Helianthus tuberosus L. Articholie. Missouri Valley, Ute.

Heliopsis helianthoides (L.) B. S. P. Ute.

Heracleum lanatum Michx. Cow-parsnip. Calhoun, Missouri Valley.

Humulus lupulus L. Hop. Turin, Grant Center.

Hydrophyllum virginianum L. Water-leaf. Turin, Missouri Valley, Calhoun, Ute.

Hystrix patula Mœnch. Ute.

Impatiens pallida Nutt. Pale Touch-me-not. East of Missouri Valley, Ute. Grant Center.

Juglans nigra L. Blacli Walnut. Ute, Missouri Valley, Grant Center.

Lactuca floridana (L.) Gærtn. Ute.

Laportea canadensis (L.) Gaud. Ute.

Lappula virginiana (L.) Greene. -Ute, Grant Center.

Lonicera glaucescens Rydb. Yellow Honey-suckle. Pisgah.

Lonicera Sullivantii Gray. Yellow Honey-suckle. Missouri Valley, Calhoun. Menispermum canadense L. Moonseed. Missouri Valley, Ute, Grant Ccnter. Mnium cuspidatum Hedw. Calboun.

Monotropa uniflora L. Indian Pipe. Magnolia.

Morus rubra L. Mulberry. Calhoun.

osmorrhiza longistylis (Torr.) DC. Sweet Cicely. Missouri Valley, Calhoun, Ute.

osmorrhiza longistylis var. villicaulis Fern. Turin, Calboun, Ute, Grant Center. 
Ostrya virginiana (Mill.) K. Koch. Iron-wood. Missouri Valley, Grant Center, Pisgah, Ute, Logan.

Oxalis flipes Small. Ute, Grant Center.

oxalis stricta L. Yellow Wood Sorrel. Missouri. Valley, Calhoun, Grant

Center.

Parietaria pennsylvanica Muhl. Turin, Grant Center.

Phlox divaricata L. Wild Sweet William. Turin, Missouri Valley, Grant

Center, Calhoun, Ute.

Phryma leptostachya L. Ute.

Pilea pumila Gray. Logan, Ute, Grant Center.

Poa pratensis L. Blue grass. Calhoun, Grant Center.

Polygonatum biflorum (Walt.) Ell. Smaller Solomon's Seal. Pisgah.

Polygonatum commutatum (R. \& S.) Dietr. Solomon's Seal. Turin, Missouri Valley, Grant Center, Calhoun, Ute.

Polygonum dumetorum L. Calhoun, Ute.

Prunus americana Marsh. Wild Plum. Turin, Ute, Grant Center.

Prunus virginiana L. Choke Cherry. Turin, Missouri Valley, Grant Center, Calhoun, Ute, Logan.

Psedera quinquefolia (L.) Greene. Virginia Creeper. Ute, Grant Center. Quercus macrocarpa Michx. Bur-oak. Turin, Missouri Valley, Ute, Grant Center.

Quercus macrocarpa var. olivaeformis (Michx. f.) Gray. Missouri Valley, Mapleton.

Quercus velutina Lam. Yellow Oak, Black Oak. Near Logan.

Ranunculus abortivus L. Turin, Missourì Valley, Ute, Grant Center.

Rhamnus lanceolata Pursh. Buck-thorn. Calhoun, Logan.

Rhus glabra L. Smooth Sumac. Missouri Valley, Ute.

Rhus toxicodendron L. Poison Ivy. Ute, Grant Center.

Ribes Cynosbati L. Prickly Gooseberry. Ute.

Ribes floridum L'Her. Ute.

Ribes gracile Michx. Wild Gooseberry. Turin, Missouri Valley, Ute, Grant Center.

Rosa Woodsi Lindl. Wild Rose. Calhoun.

Rubus allegheniensis Porter. Black-berry. Pisgah, Calhoun.

Rubus occidentalis L. Wild Raspberry. Missouri Valley, Calhoun, Grant Center.

Rudbeckia triloba L. Calhoun, Onawa.

Salix aiscolor Muhl. Pussy Willow. Turin.

Sanguinaria canadensis L. Blood-root. Ute, Grant Center.

Sanicula marilandica L. Missouri Valley, Pisgah, Calhoun, Ute, Grant Center.

Scrophularia marilandica L. Ute.

Silene stellata (L.) Ait. f. Starry Campion. Missouri Valley, Ute.

Smilax ecirrhata Englm. Ute.

Smilax herbacea L. Carrion-flower. Turin, Calhoun.

Smilax hispida Muhl. Green-brier. Missouri Valley, Ute, Grant Center.

Solanum nigrum L. Black Night-shade. Missouri Valley.

Symphoricarpos orbiculatus Mœnch, Indian Currant. Missouri Valley, Turin. 
Symphoricarpos occidentalis Hook. Wolf-berry. Turin, Ute, Grant Center. Taraxacum officinale Weber. Dandelion. Missouri Valley, Ute, Grant Center. Thalictrum revolutum DC. Turin, Calhoun, Grant Center.

Tilia americana L. Bass-wood. Missouri Valley, Ute, Turin, Grant Center. Triosteum perfoliatum L. Horse-gentian. Calhoun, Ute, Grant Center.

Ulmus americana L. White Elm. Missouri Valley, Ute, Grant Center.

Ulmus fulva Michx. Red Elm. Missouri Valley, Ute, Grant Center.

Ulmus racemosa Thomas. Cork Elm. Missouri Valley.

Viola cucullata Ait. Blue Violet. Turin, Grant Center.

Viola pubescens Ait. Yellow Violet. Ute.

Viola scabriuscula Schw. Smooth Yellow Violet. Mapleton, Ute, Grant Center.

Viola sororia Willd. Blue Violet. Turin, Missouri Valley, Ute.

Vitis vulpina L. Wild Grape. Missouri Valley, Ute, Grant Center.

Zanthoxylum americanum Mill. Prickly-ash. Missouri Valley, Ute, Grant Center.

\section{PLANTS OF ALLUVIAL GROVES}

Acer negundo L. Box Elder. Logan, California Junction, Blair bridge.

Acer saccharinum L. Soft Maple. Logan.

Amorpha fruticosa L. Wild Indigo. Calhoun, Little Sioux, Blair bridge.

Aster lateriflorus L. Britt. Wild Aster. Little Sioux.

Celtis occidentalis var. crassifolia (Lam.) Gray. Hackberry. Pisgah, Modale.

Cornus paniculata L'Her. Dog-wood. California Junction, Blair bridge.

Crataegus mollis (T. \& G.) Scheele. Red Haw. California Junction, Blair bridge.

Echinocystis lobata (Michx.) T. \& G. Wild Cucumber. Logan, Turin.

Evonymus atropurpureus Jacq. Wahoo. Little Sioux.

Eupatorium urticaefolium Rich. Onawa.

Festuca nutans Spreng. Fescue Grass. Onawa.

Fraxinus pennsylvanica Marsh. Green Ash. California Junction.

Gleditsia triacanthos L. Honey Locust. California Junction.

Gymnocladus dioica (L.) Koch. Kentucky Coffee-bean. Logan.

Juglans nigra L. Black Walnut. Missouri Valley, Turin, etc.

Leersia virginica Willd. White Grass. Logan.

Morus rubra L. Mulberry. Pisgah.

Pilea pumila (L.) Gray. Rich-weed. Logan.

Polygonum lapathifolium L. Smart-weed. Logan, Ute.

Populus deltoides Marsh. Cotton-wood. Logan, California Junction, Blair bridge, etc.

Prunus americana Marsh. Wild Plum. California Junction.

Psedera quinquefolia (L.) Greene. Virginia Creeper. California Junction, Blair bridge.

Quercus macrocarpa Michx. Bur-oak. California Junction.

Radicula palustris (L.) Monch. Marsh Cress. Logan.

Ranunculus septentrionalis Poir. Butter-cup. Turin.

Rhus glabra L. Smooth Sumac: Missouri Valley, etc.

Rhus toxicodendron L. Poison Ivy. Missouri Valley, etc.

Ribes floridum (L.) L'Her. Flowering Currant. California Junction. 
Ribes gracile Michx. Wild Gooseberry. California Junction.

Rudbeckia laciniata L. Cone-flower. Logan.

Rumex altissimus Wood. Tall Dock. Missouri Valley, Onawa.

Salix amygdaloides Anders. Peach-leaved Willow. Missouri Valley, California

Junction, Logan, Blair bridge.

Salix discolor Muhl. Pussy Willow, Logan.

Salix longifolia Muhl. Sand-bar Willow. Logan.

Salix missouriensis Bebb. Missouri Willow. Missouri Valley, etc.

Salix nigra Marsh. Black Willow. Logan.

Sambucus canadensis $\mathrm{L}$. Elder-berry. California Junction, Missouri Val-

Sambucus canadensis L. Common Elder-berry. California Junction, Mis-

souri Valley.

Sanicula marilandica L. Black Snake-root. California Junction.

Sicyos angulata L. Bur Cucumber. Little Sioux.

Silphium perfoliatum L. Cup-plant. Logan.

Solidago serotina Ait. Golden-rod. Logan.

Stachys palustris L. Wound-wort. Blair bridge.

Stachys tenuifolia Willd. Logan.

Ulmus americana L. White Elm. California Junction, Blair bridge, etc.

Ulmus fulva Michx. Red Elm. Logan.

Urtica gracilis Ait. Nettle. Logan, Mapleton.

Vitis vulpina L. Wild Grape. Logan, Missouri Valley, etc.

Zanthoxylum americanum Mill. Prickly Ash. Modale.

PLANTS OF LOW GROUNDS, MARSHES, ETC.

Acnida tuberculata Moq. Onawa. Low grounds.

Ammania coccinea Rottb. Blair bridge, Modale. Swamps.

Artemisia biennis Willd. Pisgah. Low grounds.

Bidens cernua L. Pisgah. Borders of ponds, etc.

Bidens vulgata Greene. Spanish Needles. Ute. Moist grounds.

Boltonia asteroides (L) L'Her. Turin, Missouri Valley. Low places.

Calamagrostis canadensis (Michx.) Beauv. Blue Joint-grass. Onawa. Low grounds.

Carex Bebbii Olney. Missouri Valley, Onawa. Low grounds.

Carex crus.corvi Shuttlw. Onawa, Modale. Swamps.

Carex lanuginosa Michx. California Junction, Denison. Low grounds.

Carex riparia W. Curtis, California Junction. Low grounds.

Carex scoparia Schk. California Junction. Low grounds.

Carex stricta Lam. Missouri Valley. Low grounds, swamps.

Carex stricta var. angustata (Boott) Bailey. California Junction. Low places.

Carex trichocarpa Muhl. Califolnia Junction. Low places.

Carex tribuloides Wahl. Missouri Valley. Borders of swamps.

Carex vulpinoidiea Michx. Missouri Valley, Onawa, Pisgah. Low grounds.

Cornus stolonifera Michx. Red Osier. Modale. Borders of swamps.

Cyperus acuminatus Torr. \& Hk. Blair bridge. Wet places.

Cyperus aristatus Rottb. Blair bridge. Wet places.

Cyperus erythrorhizos Muhl. Modale. Wet grounds.

Cyperus esculentus L. Onawa. Wet grounds.

Cyperus rivularis Kunth. Blair bridge, Modale. Low grounds.

Cyperus strigosus L. Blair bridge. Low places. 
Echinodorus cordifotius (L.) Griseb. Missouri Valley, Blair bridge. Ponds. Eleocharis palustris (L.) R. \& S. Onawa. Swamp borders.

Eleocharis tenuis (Willd.) Schultes. Pisgah. Swamp borders.

Eupatorium perfoliatum L. Boneset. Missouri Valley. Low places.

Gerardia tenuifolia Vahl. Missouri Valley. Swamp borders.

Helenium autumnale L. Sneeze-weed. Missouri Valley. Low grounds. .

Helianthus grosseserratus Mart. Saw-tooth Sunflower. Onawa, Logan. Low places.

Iris versicolor L. Blue Flag. Missouri Valley. Swamps and wet grounds.

Lippia lanceolata Michx. Missouri Valley. Low places.

Lobelia siphilitica L. Blair bridge. Low grounds, borders, etc.

Lycopus americanus Muhl. Water Hoarhound. Blair bridge. Bogs.

Lythrum alatum Pursh. Modale. Wet places.

Mentha arvensis var. canadensis (L.) Briq. Pisgah. Bogs.

Nelumbo lutea Pers. Yellow Nelumbo. Onawa. Ponds.

Panicum huachucae var. silvicola Hitch \& Chase. Blair bridge. Low grounds.

Phalaris arundinacea L. Missouri Valley, Little Sioux. Wet places.

Poa triflora Gilib. Onawa, Blair bridge. Low grounds.

Polygonum lapathifolium var. incarnatum Wats. Turin. Low grounds.

Polygonum Muhtenbergii (Meisn.) Wats. Missouri Valley, Modale. Ponds.

Potamogeton illinoiensis Morong. Blair bridge. Ponds.

Potamogeton pectinatus L. Mapleton. Ponds.

Potentilla paradoxa Nutt. Blair bridge. Borders of ponds, etc.

Radicula palustris (L.) Mœnch. Missouri Valley, Pisgah. Swamps.

Radicula sinuata (Nutt.) Greene. California Junction, Little Sioux. Swamps.

Ranunculus cymbalaria Pursh. Blair bridge, Pisgah. Wet borders.

Rumex altissimus Wood. Onawa, Missouri Valley. Low grounds.

Sagittaria latifolia Willd. Missouri Valley. Swamps.

Salix amygdaloides Anders. Peach-leaved Willow. Blair bridge. Low grounds.

Salix cordata Muhl. Heart-leaved Willow. Mapleton. Low grounds.

Salix aiscolor Muhl. Pussy Willow. Pisgah. Bogs, etc.

Salix Tongifolia Muhl. Sand-bar Willow. Missouri Valley. Wet borders.

Salix missouriensis Bebb. Missouri Willow. Blair bridge. Low places.

Scirpus americanus Pèrs. Blair bridge. Borders of ponds and swamps.

Scirpus atrovirens L. Missouri Valley, Grant Center, Modale. Ponds and swamps.

Scirpus validius Vahl. Missouri Valley, Blair bridge. Ponds and swamps.

Scutellaria lateriflora L. Mad-dog Skull-cap. Turin. Wet places.

Sphenophotis pallens (Spreng.) Scrib. Missouri Valley. Low grounds.

Spiranthes cernuc (L.) Rich. Blair bridge. Low places, in sand.

Sporobolus heterolepis Gray. Blair bridge. Low sandy places.

Stachys palustris L. Blair bridge. Low grounds.

Stachys palustris var. homotricha Fern. Onawa. Low grounds.

Steironema citiatum. (L.) Raf. Calhoun. Wet places.

Typha latifolia L. Cat-tall. Missouri Valley, Blair bridge. Ponds and swamps.

Pernonia fasciculata Michx. Iron-weed. Missouri Valley, Modale, Turin. Low grounds. 
Cratty also reports the following species in the Bulletin from the Laboratories of Natural History, State University of Iowa, vol. III, from the localities cited:

Eleocharis palustris (L.) R. \& S. Missouri Valley, p. 325.

Scirpus atrovirens Mubl. Woodbine, p. 330.

Carex lanuginosa Michx. Missouri Valley, p. 341.

Carex vulpinoidea Michx. Missouri Valley, p. 354.

The foregoing lists contain all the plants which were collected in the respective habitats, and while they are probably not complete they present a comparative view of the flora of our territory which will not be materially affected by any additions which may be made to any of the lists. The prairie flora is distinctly set apart from the others and is the most constant and most characteristic feature of the prairies of whatsoever type.

EXPOSURE TO EVAPORATION

Another common characteristic of all prairie is exposure to the two great factors which control evaporation, the sun and wind. The maximum heat of the day is reached at about two o'clock in the afternoon. The "two o'clock sun" beats down upon the southerly and southwesterly slopes of rough areas, and equally affects uniformly flat areas; the prevailing. winds of summer to which the prairie flora is exposed are from: the south or southwest, and the sun-scorched southwesterly slopes are also most exposed to these winds, the flat prairie again suffering almost equally. Countless illustrations of the effect of this exposure may be observed throughout Iowa and neighboring states, but none are finer than those which may be seen in Harrison and Monona counties.

The contrast between the exposed Missouri bluffs and the inland sheltered valleys is almost everywhere sharp. This is well illustrated by the two figures on plate XXXIII. Figure 1 shows the faces of the bluffs just above Missouri Valley. They are here fully exposed to the west and southwest, and both sun and wind have free play. The result is that only the xerophytic flora of the prairie can exist under the trying conditions. Figure 2 shows the sheltered valley on the east side of the same ridge. Neither sun nor wind can operate as effectively in the sheltered valley and the result is the development of the mesophytic flora 
of the forest. Plate XXXIV also furnishes a fine illustration. Here the two views were taken from the same point,-figure 1 looking southeast toward the prairie ridge which has its side exposed to the west and southwest; and figure 2 looking southwest toward the sheltered slope which is covered with forest growth.

The ridge at Turin, plate XXIII, figure 2, extends in a southwesterly direction and both of its sides are exposed and both are covered with a prairie flora.

Illustrations of this kind may be multiplied indefinitely both in and outside of our territory, and several are furnished by the illustrations of this report. Thus, plate $\mathrm{XXI}$, figure 1, shows the exposed faces of Murray hill, which are covered wholly with a typieal prairie flora; plate XXII, figure 1, shows similar surfaces near Pisgalı; plate XXXI, figure 2, illustrates the exposed Missouri bluffs in southern Monona county; plate XXXVI, figue 1, shows a series of short ridges projecting into a valley which opens to the southwest, the exposed top of each ridge being prairie and each valley sheltering a bur-oak grove; and figures 32 and 33 bring out the contrast between the prairie slopes on the exposed bluffs of the Missouri above Missouri Valley, and the sheltered forested bluffs nearly opposite, above Florence, Nebraska.

In many places there are northern and eastern slopes which are also devoid of groves. Sometimes this is due to the fact that local topography causes a lateral deflection of the prevailing winds in such manner that these slopes are more freely swept by them. The.deflection is sometimes downward, as along surfaces which slope downward gradually toward the north. In such cases the currents of air follow the sloping surface in accordance with the well-known tendency of moving gasses to follow somewhat irregular surfaces," whereas when the northern slope is more abrupt the prevailing southwesterly winds often pass over without following it. In the latter case, however, there is sometimes a division of the current as illustrated

* Plate XXXVI, figure 2, illustrates such prairie areas on gradual northern siopes. 


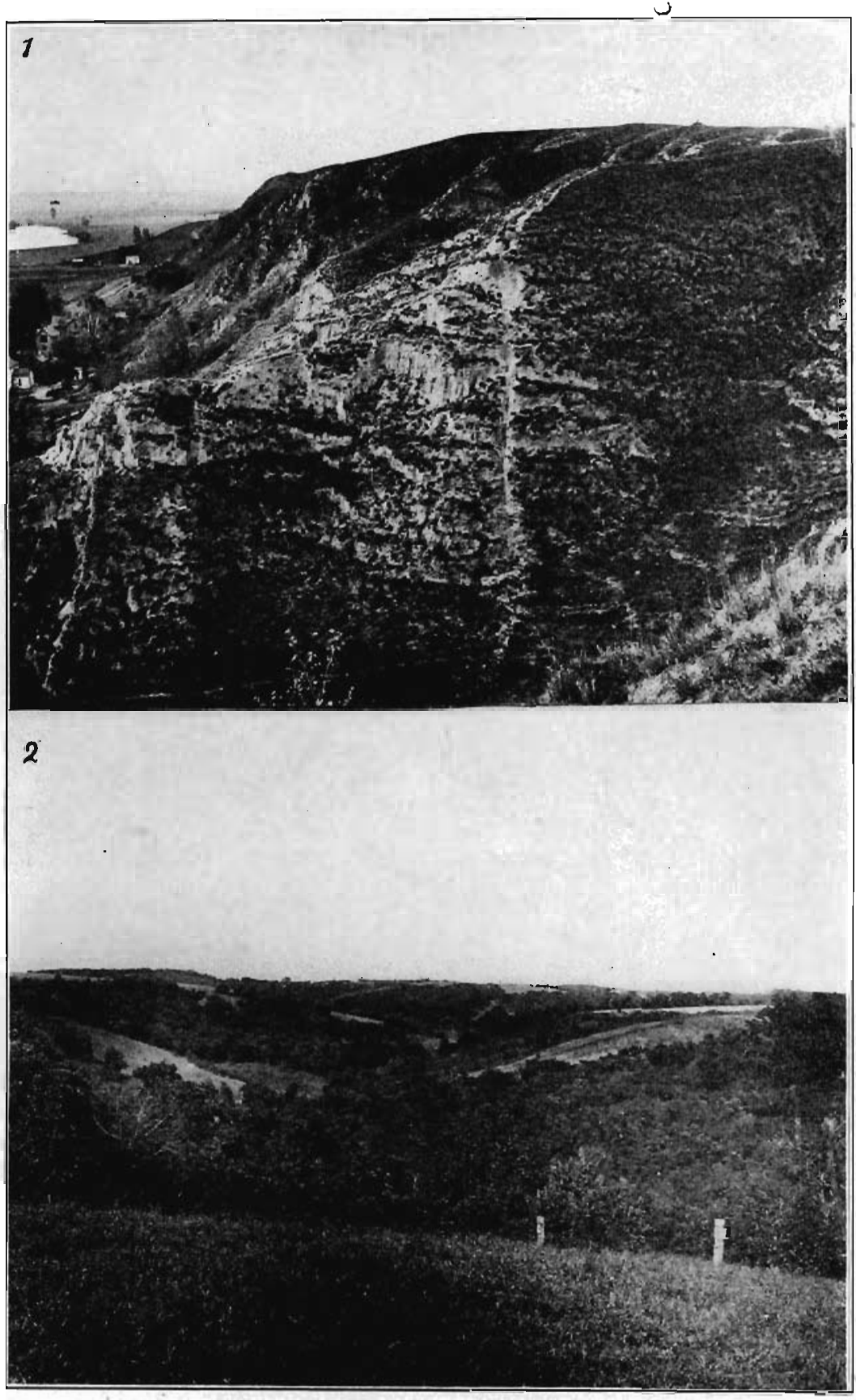

Plate XXXIII.-Missouri Valley topograply and groves. (1) Looking uorth along main bluffs in Missouri Valley (pp. 284, 392, 400, 431, 445). (2) Snyder's Hollow. Looking northeast from top of ridge in (1). (See pp. 393,445 .) 



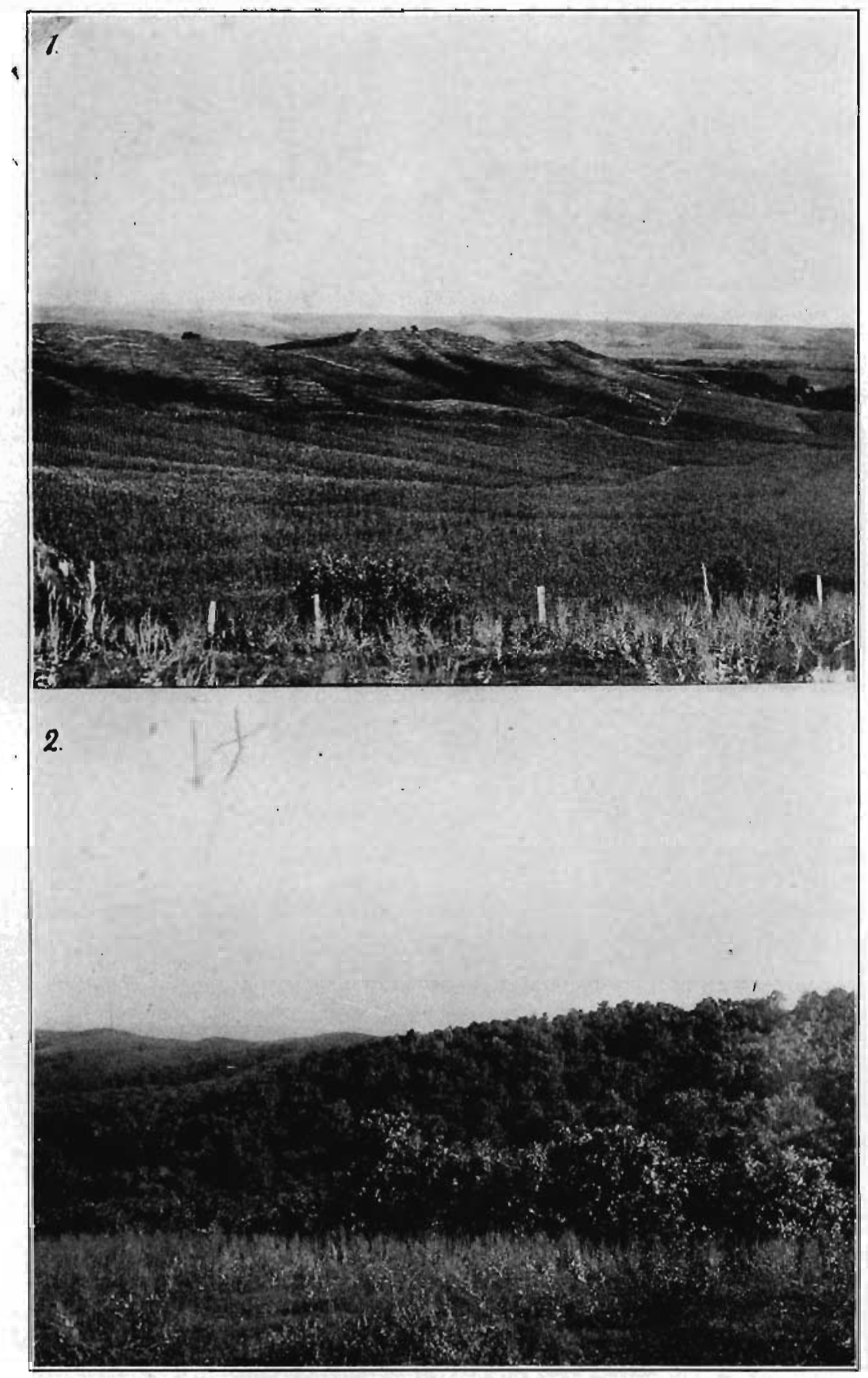

Plate XXXIV-Prairie and forest in section 27 township 84 north, range 44 west (p. 284). (1) Looking southeast at exposed slopes. (2) Looking southwest at timbered slopes. (See pp. 284, 446.) 
.
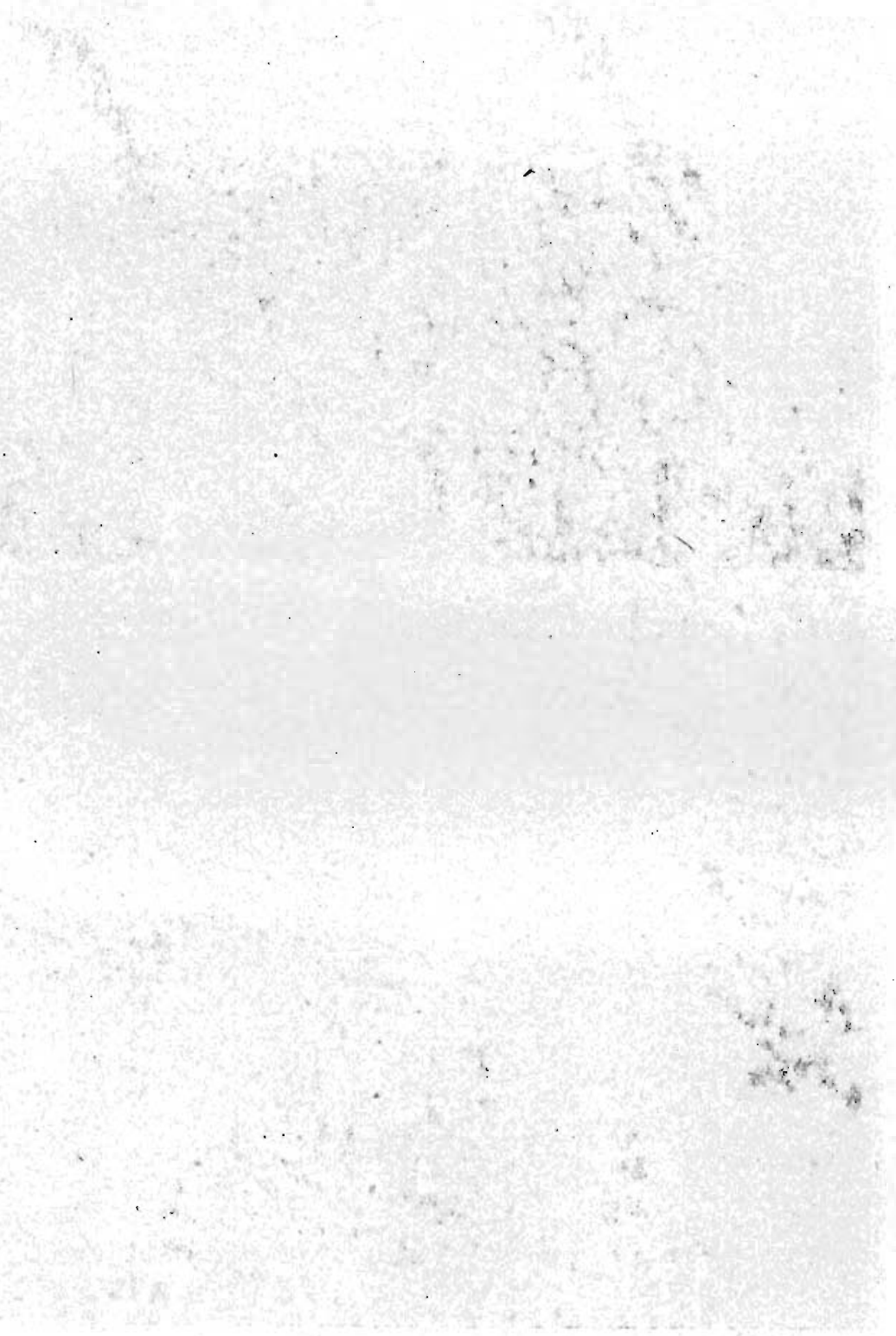


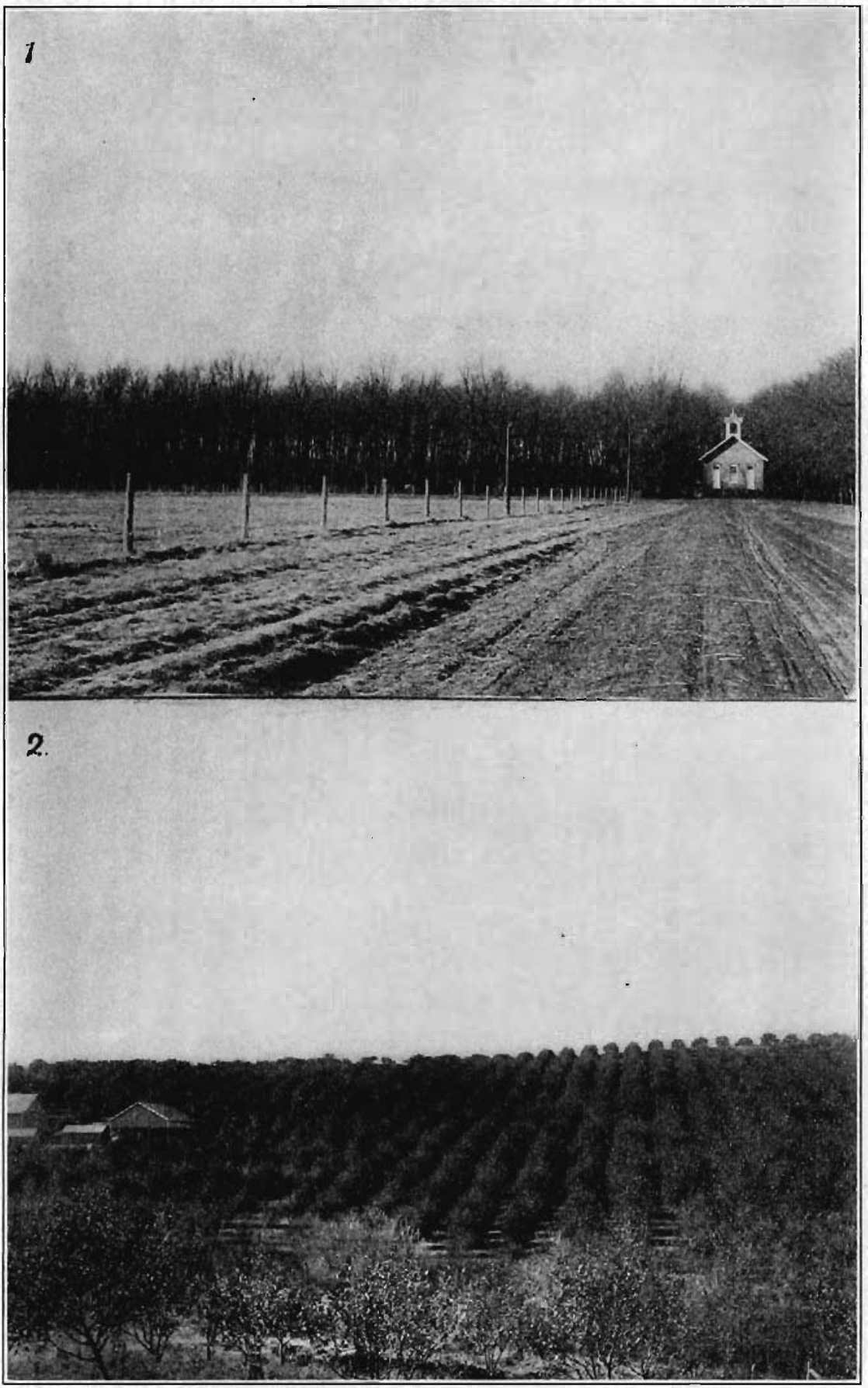

Plate XXXV.-Artificial groves. (1) Whiting grove in northeast quarter section 25 , township 85 north, range 46 west. Looking west (p. 475 ). (2) Deur orchard, section 1, township 78 north, range 44 west. (See p: 415 .) 


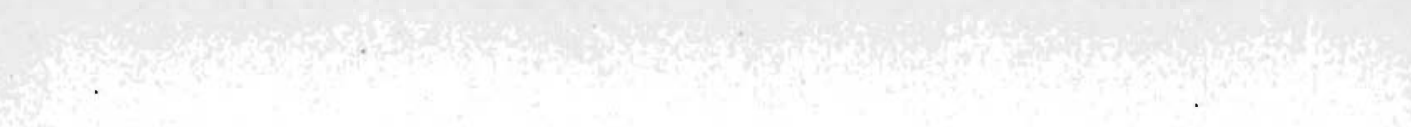
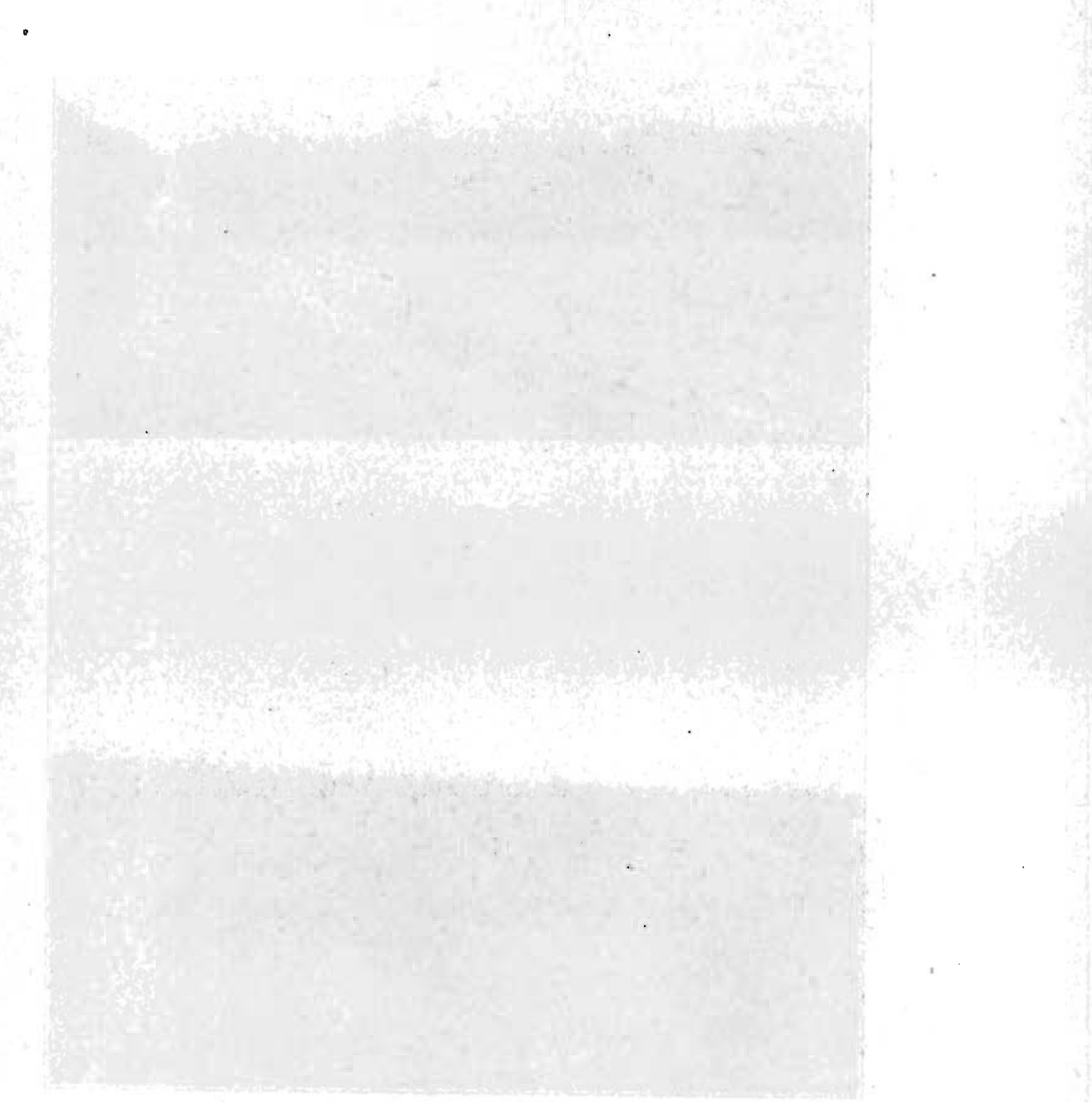

$x^{2} x^{2}$ 


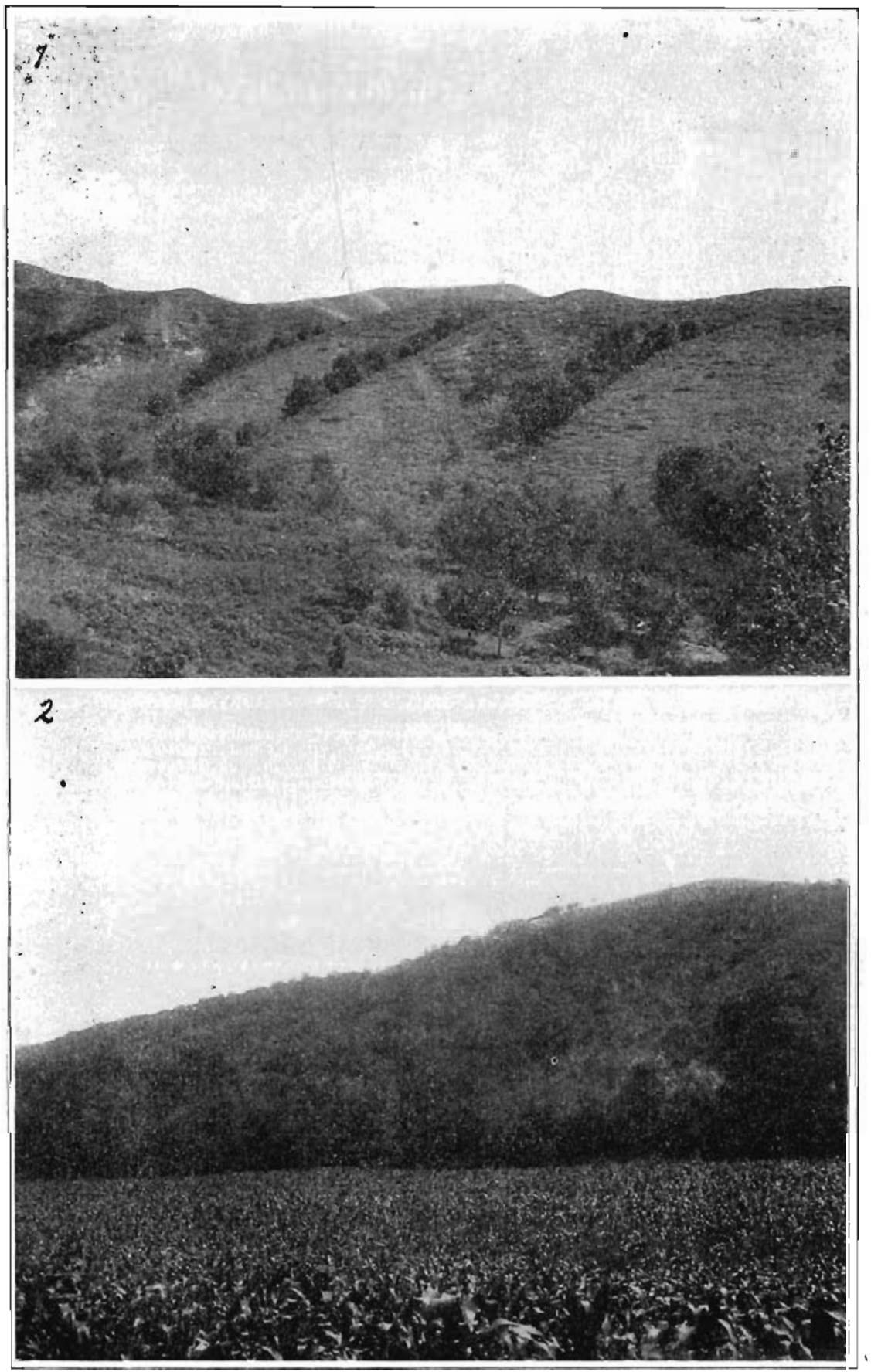

Plate XXXVI.-Prairie ridges. (1) Sheltered ravines with buroaks, looking south from Murray Hill. (2) Looking southeast in section 15, township 84 north, range 44 west. (See p. 446.) 


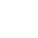


in figure 37 , in which case a part of the current sweeps back up the leeward slope. This occurs in rough territory where ridge after ridge intercepts the air-currents and causes disturbances in their lower strata, and was observed only where ridges in front (to the right in the figure) caused this deflection. The writer has frequently tested this by releasing bits of paper, the pappus of composites and other light objects from the summits of such ridges, and invariably when strong winds were blowing most of these objects were swept upward again, often to the feet of the experimenter. In such cases the leeward slope is

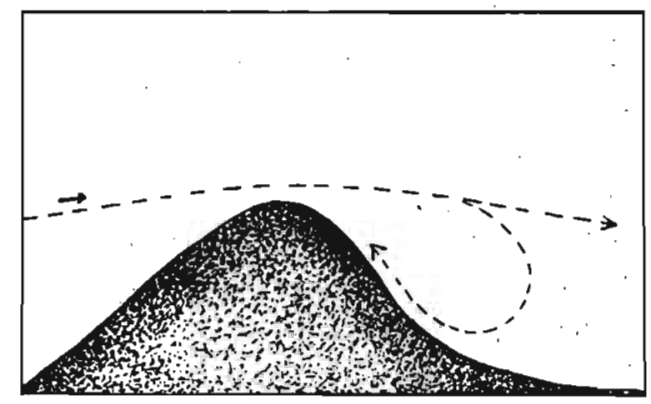

Figure 37. Arrows show the direction of the wind. On the leeward side a part of the current sweeps back up the hill.

almost as much exposed to the dry winds as the windward side, and it is then wholly or largely prairie. In all the preceding cases the prairie areas are distinctly exposed to the prevailing summer winds.

In all cases where the topography of the prairie is rough the rapid run-off of the rains precipitated upon the steep slopes assists in more rapidly making the surfaces xerophytic. That this is not the prime cause however is evident from the fact that steep slopes (especially those facing the north or northeast) are densely covered with a mesophytic forest-growth where sheltered from the winds. Excellent illustrations are furnished by Snyders Hollow at Missouri Valley and Woodwards Glen at Grant Center, where prominent ridges cut off the prevailing summer winds, and by practically every timbered hollow or valley in our territory, for all are similarly situated. The fact 
that the groves are practically restricted in this and similar territory to the roughest areas is also worthy of consideration.*

That other obstructions than those produced by topographic features have a similar influence upon vegetation is illustrated by plate XXXVII which shows two views of a prairie grove near George, Iowa. Figure 1 shows the sheltered interior of the grove (looking east), here cut by a road. The walnuts on the south side of the road are prospering in the shelter of their companions which form the southern' part of the grove. Figure 2 shows the southwest corner of the same grove, growing on the same kind of surface, but at this point exposed fully to the sun and wind from the southwest because lacking the protection of other trees. The walnuts in this part of the grove are stunted and dying out.

The striking distribution of the groves on rougher lands in the western part of Iowa and elsewhere suggested a series of observations on the relative rate of evaporation from the sheltered and protected slopes. The bluffs and ridges bordering the Missouri valley on the east side are especially well suited for such observations as the exposure of the faces of the bluffs is extreme, and as the ridges are often very sharp so that the transition from prairie to forest is very abrupt.

\section{Evaporatiox.}

In order that all the conditions affecting evaporation might be properly taken into account a series of meteorological observations was undertaken at Missouri Valley in the summer of 1908. This work included observations on evaporation; temperature and relative humidity, velocity and direction of wind, clearness of sky, barometric pressure, and in a general way on rain-fall.

Evaporation. An effort was made to employ three kinds of evaporimeters. An open tin pan, one foot in diameter, and with upright sides, was buried to the rim at each of the four stations described below.

\footnotetext{
*The clumps and narrow belts of trees along the larger streams on the allúvial plain form an exception to the rule. The diffusion of moisture from the stream in both soil and air evidently makes this possible as the plants in these beits are all mesophytic with the possible exception of the partly xerophytic cottonwood which thrives in liarger groves on the sandy areas bordering the Mịssouri because its extensive root-system is developed largely in the water-laden sand-beds of the bottomlands.
} 


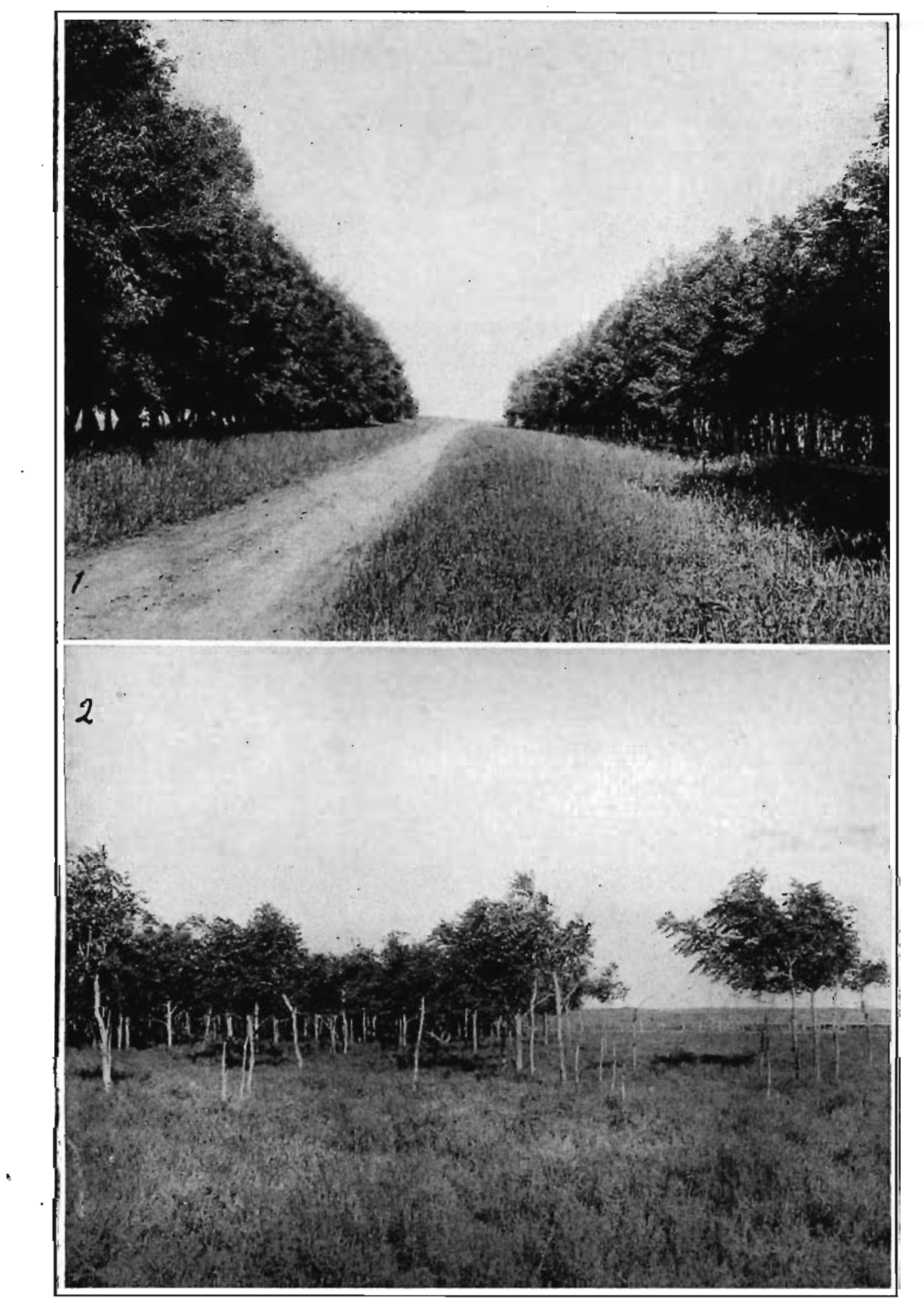

Plate XXXVII.-Walnut grove near George, Iowa. 1.-Looking east through the sheltered part. 2.-Looking east at the exposed southwest corner. (See p. 450). 
p. [452]

(vol.20.) 
At two of the stations Piche evaporimeters, graduated to hundredths of a cubic inch, were suspended eight inches above the surface of the soil on iron rods driven into the ground. These evaporimeters were frequently tested and worked together perfectly.

An effort was also made to employ porous cup-evaporimeters at these two stations, ${ }^{*}$ but owing to various accidents they failed several times.

Temperature and relative humidity. For this purpose a Marvin Sling Psychrometer with the Fahrenheit scale (the U. S. standard) was employed, rain-water being used.for the wetbulb. Readings were also taken from two Centigrade psychrometers as an additional check.

Wind velocity. The velocity of the wind was measured at one of the stations (number one) by a Green's cup anemometer which was set up at this station throughout each of the observation days. A small mill anemometer (air-meter) was also employed for short periods at various intervals at all the stations.

Barometric pressure. This was measured by an Aneroid barometer.

Rain-fall: No effort was made to measure the rainfall, but during August and September, 1908, when these observations were made, Mr. Stern reported the rainfall at Logan, eight miles away, as follows:

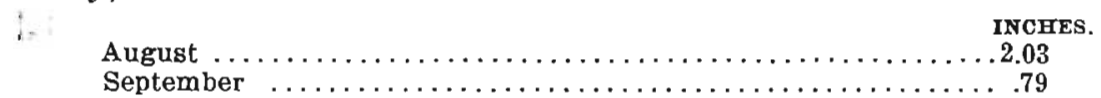

This also probably approximately measured the rainfall at Missouri Valley, and by far the greater part of this was precipitated during the first half of August, which was decidedly rainy. The latter half of August and the first half of September were very dry. By the middle of September the hills were dry and brown, and in the more exposed places only a few of the more pronounced xerophytes were in flower. The following were observed in flower at that lime near. stations (1) and (3):

Aster oblongifolius

Aster sericeus

Chrysopsis villosa

Grindelia squarrosa

Helianthus scaberrimus
Kunnia eupatoroides var. corymbutosa.

Liatris punctata

Solidago speciosa var. angustata

Solidago rigida

*These were kindly furnlshed for the purpose by Dr. Forrest Shreve of the Carnegle Desert Botanical Laboratory. 
By this time even the leaves on the bur-oaks curled, and during the day most plants which still retained leaves were wilted.

The stations. Four stations were selected for the observations.

Station 1 was located at an elevation of 140 feet above the alluvial plain on the west side of the ridge forming the bluffs of the Missouri valley just above Missouri Valley. It was fully exposed to the southwest and west, but was somewhat sheltered by the ridge to the south and southeast. Its vicinity was covered with a typical prairie flora. This station, with some of the apparatus in place is shown in the foreground in plate XXXVIII, figure 1, looking south, and at the point marked (1) in plate XXXIX, figure 1, looking east.

Station 2 was located in the grove on the leeward side of the same ridge at the same altitude as station (1), and ninety-five feet east of it. It was stationed fifty feet east of the west edge of the grove shown to the left in plate XXXIX, figure 1, and also in plate XXXVIII, figure 2. The latter figure also shows in the foreground the border strip, about twenty-five feet wide, which separates the grove in which this station is located from the typical prairie surrounding station (1). The latter station is located about twenty feet west of the west side of this border strip. The border strip follows the very top of the ridge between stations (1) and (2), and the latter station is sheltered partly by this intervening low ridge and to a greater extent by the higher ridge to the south, besides being under cover of the forest.

The observations at stations (1) and (2) should be compared to show the combined influence of the protecting ridge and grove on evaporation.

The floras of the two stations were very distinct. That of the prairie at stations (1) and (3), which is essentially one, is recorded in the first (or loess) column of the table of prairie plants. In the immediate vicinity of station (2) the following plants were collected, practically all, excepting the introduced weeds, belonging to the flora of the forest: 


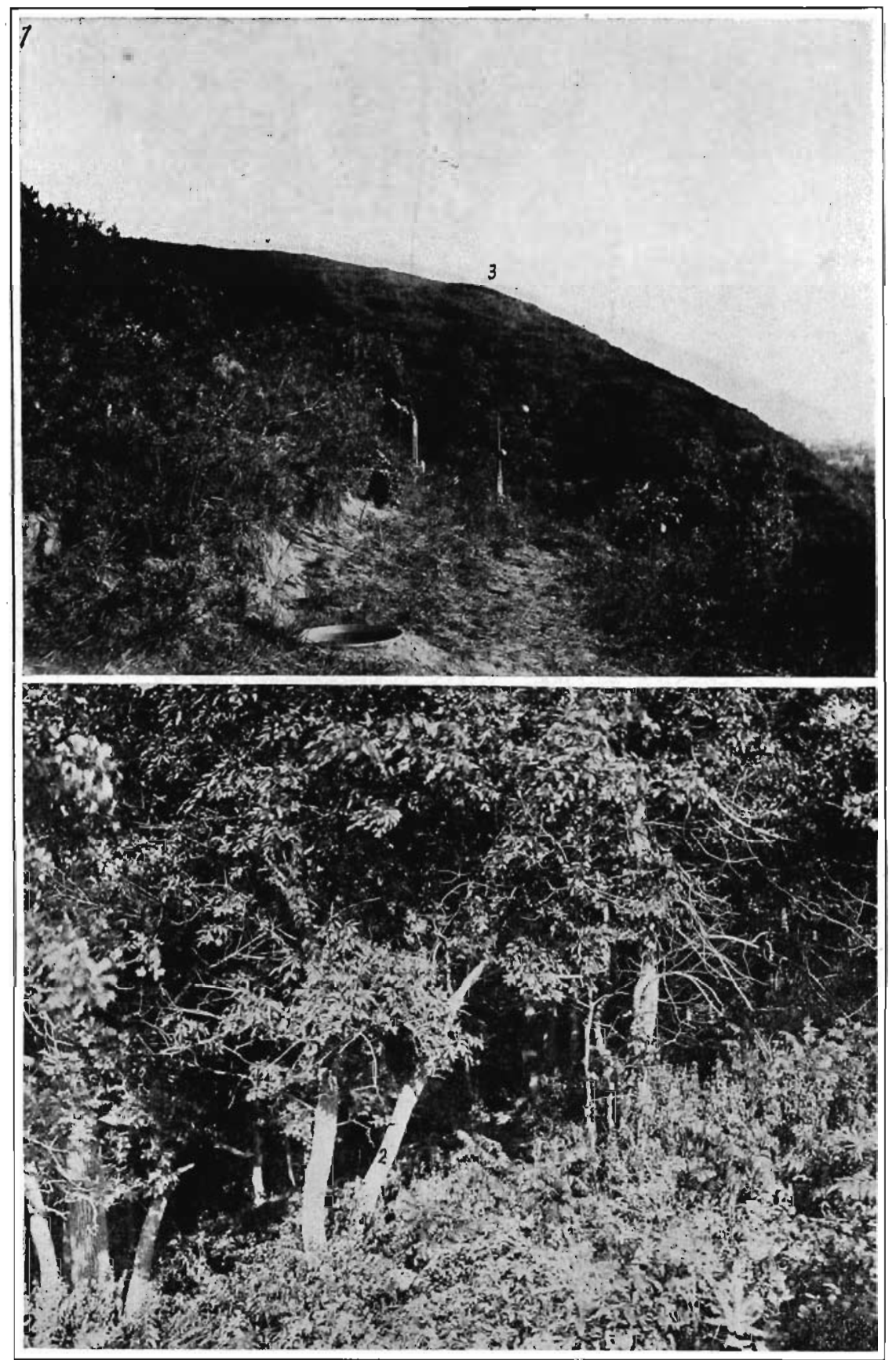

Plate XXXVIII.-Meteorological stations, Missouri Valley. (1) Looking south across stations (1) and (3). (2) Looking east toward station (2) in grove in line with buroak marked (2). (See pp. 454 and 459 .) 
p. $[456]$

$(v .20)$ 


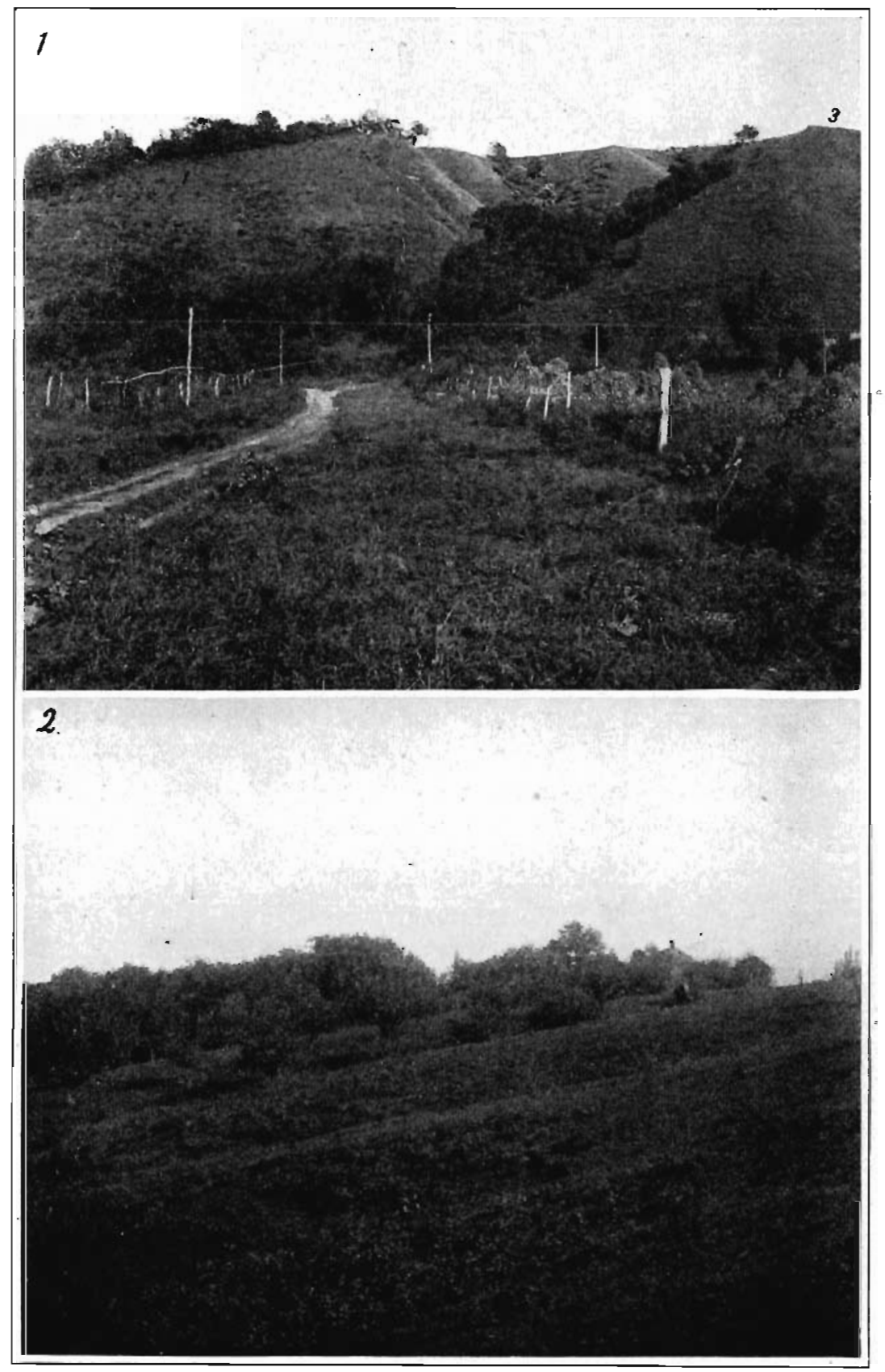

Plate XXXIX.-Meteorological stations, Missouri Valley. (1) Lookins east toward stations (1) and (3). (2) Looking east of south toward station (4). (See pp. 454 and 459 .) 
Corylus americana

Crataegus mollis

Cystopteris fragilis

Dicentra cucullaria

Ellisia nyctelea

Elymus striatus

Eupatorium urticaefolium

Festuca nutans

Fraxinus pennsylvanica

Hydrophyllum virginianum

Ostrya virginiana

Polygonatum commutatum

Prunus virginiana

Psedera quinquefolia

Quercus macrocarpa
Ranunculus abortivus

Rhus glabra (large)

Ribes gracile

Silene stellata

Smilax hispida

Solanum nigrum (introduced)

Symphoricarpos orbiculatus

Taraxacum offcinale (introduced)

Tilia americana

Olmus americana

Olmus fulva

Viola sororia

Vitis vulpina

Zanthoxylum americanum

The following plants were collected on the border strip between stations (1) and (2). They present a mixture of species of both forest and prairie, the latter predominating:

\author{
Amorpha canescens \\ Anemone cylinarica \\ Aster sericeus \\ Ceanothus ovatus var. pubescens \\ Eupatorium altissimum \\ Fragaria virginiana \\ Fraxinus pennsylvanica (small) \\ Gerardia aspera
}

\author{
Hetianthus scaberrimus \\ Monarda mollis \\ onosmodium occidentale \\ Poa pratensis \\ Quercus macrocarpa var. olivaeformis \\ Rhus glabra (small) \\ Sanicula marilandica \\ Symphoricarpos occidentalis
}

Station 3 was located on the most prominent point on this side of the bluffs, and fully exposed to the south and west. It was about 350 feet almost due south of station (1), and like the latter was surrounded by a distinct prairie flora. Its position is shown at the point marked (3) in plate XXXVIII, figure 1, and plate XXXIX, figure 1.

This was the most exposed station of the series.

Station 4 was located on the east side of the same ridge, at a point 375 feet east and 220 feet south of station and at the same altitude as that station. The ridge between stations (3) and (4) rises about twenty-five feet above them and its slope on the east side is sufficiently steep to afford protection from excessive evaporation on that side. The eastern slope was formerly covered with forest, but this had been removed and a young orchard has been set out on a part of the slope. Station (4) was in an open place sheltered only by the 
ridge but in an area which had been but recently forested. This , station is shown at the point marked (4) in plate XXXIX, figure 2 , looking south along the cleared slope.

The observations at stations (3) and (4) should be compared to bring out the protective influence of the ridge alone.

Care was exercised in placing the pieces of apparatus required for these observations in such manner that they did not interfere with $\epsilon$ ach other.

The observations were continued for a whole day at intervals of about a week from the 13th of August to the 12th of September. Each observation day was given wholly to this work and hourly readings (excepting those of the evaporating pans) were made from 7 o'clock A. M. to 7 o'clock P. M. Earlier and later readings were also at first taken but they could not be continued as the days grew shorter and they are not here included. So far as made they did not in any way modify the results obtained.

Notwithstanding the care which was exercised in making. these readings it is probable that occasional errors were made, the possibility of which will be appreciated by those who have ventured to face the tedium of such work in midsummer in a rough territory. The results which were obtained, however, are so generally consistent, and they agree so well with observations made at other points, notably at Ute by Superintendent D. H. Boot under the writer's direction, and at Omaha and Council Bluffs and in the vicinity of Lake Okoboji, Iowa, by the writer himself, that they are here offered with the confident conviction that such errors as may have occurred are rare or insignificant and would not materially affect the general results.

Rate of Evaporation.

The several types of evaporimeters did not show the.same relative rate of evaporation at the several stations, but this was evidently due largely to the difference in position and altitude above the surface. In all cases, however, evaporation was shown to be much greater at the exposed stations (1) and (3) than at the more or less sheltered stations (2) and (4).

Evaporating pans. The evaporating pans were filled to the 
index (a pointed wire) at 7 o'clock A. M. Readings were then taken at 2 and 7. o'clock P. M. During the nights of the 13 th and 14th days of August and 28th and 29th of August, the pans were also left in the field and readings were taken at 7 o'clock A, M. On the 28th of August observations were also made from 4 to 7 o'clock P. M. and were continued on the following day.

The following table gives the totals for the times indicated:

Amount of Evaporation from Evaporating Pans.

\begin{tabular}{|c|c|c|c|c|c|}
\hline \multirow{2}{*}{$\begin{array}{l}\text { Date } \\
1908\end{array}$} & \multirow{2}{*}{ - Hours } & \multicolumn{4}{|c|}{ Stations } \\
\hline & & 1-Prairie & 2-Grove & 3-Prairie & 4-Cleared \\
\hline $\begin{array}{l}\text { Aug. } 13 \ldots \ldots \ldots \ldots \ldots \\
\text { Aug. } 21, \ldots \ldots \ldots \ldots \\
\text { Aug. } 28, \ldots \ldots \ldots \ldots \\
\text { Aug. } 29 \ldots \ldots \ldots \ldots \ldots \\
\text { Sept. } 5 \ldots \ldots \ldots \ldots \ldots \\
\text { Sept. } 12 \ldots \ldots \ldots \ldots\end{array}$ & $\begin{array}{l}6 \text { A. M.-7 P. M. } \\
7 \text { P. M.-6 A. M. } \\
7 \text { A. M.-7 P. M. } \\
4 \text { P. M.-7 P. M. } \\
7 \text { P. M.-7 A. M. } \\
7 \text { A. M.-7 P. M. } \\
7 \text { A. M.-7 P. M. } \\
7 \text { A. M.-7 P. M. }\end{array}$ & $\begin{array}{l}221 \mathrm{cc} . \\
131 \mathrm{cc} . \\
212 \mathrm{cc} . \\
84 \mathrm{cc} . \\
63 \mathrm{cc} . \\
348 \mathrm{cc} . \\
250 \mathrm{cc} . \\
357 \mathrm{cc} .\end{array}$ & $\begin{array}{l}98 \mathrm{cc} . \\
57 \mathrm{cc} . \\
46 \mathrm{cc} . \\
9 \mathrm{cc} . \\
20 \mathrm{cc} . \\
66 \mathrm{cc} . \\
47 \mathrm{cc} . \\
116 \mathrm{cc} .\end{array}$ & $\begin{array}{l}360 \mathrm{cc} . \\
144 \mathrm{cc} . \\
283 \mathrm{cc} . \\
118 \mathrm{cc} . \\
89 \mathrm{cc} \\
456 \mathrm{cc} . \\
375 \mathrm{cc} . \\
500 \mathrm{cc} .\end{array}$ & $\begin{array}{l}296 \mathrm{cc} . \\
111 \mathrm{cc} . \\
181 \mathrm{cc} . \\
58 \mathrm{cc} . \\
36 \mathrm{cc} . \\
227 \mathrm{cc} . \\
139 \mathrm{cc} . \\
213 \mathrm{cc} .\end{array}$ \\
\hline
\end{tabular}

Cup evaporimeters. At the same time the cup evaporimeters at stations (1) and (2) showed the following losses:

\begin{tabular}{|c|c|c|c|}
\hline Date & Hours & Station 1 & Station 2 \\
\hline 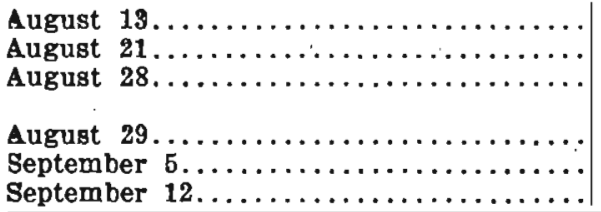 & $\begin{array}{l}6 \text { A. M.-6 P. M. } \\
7 \text { A. M.-7 P. M. } \\
4 \text { P. M.-7 P. M. } \\
7 \text { P. M.-7 A. M. } \\
7 \text { A. M.-2 P. M. } \\
7 \text { A. M.-7 P. M. } \\
7 \text { A. M.-2 P. M. }\end{array}$ & $\begin{array}{cc}37 & \text { cc. } \\
27 & \text { cc. } \\
9 & \text { cc. } \\
2.5 & \text { cc. } \\
23 \text { cc. } \\
35.5 \text { cc. } \\
13.5 \text { cc. }\end{array}$ & $\begin{array}{l}24.5 \mathrm{cc} . \\
10 \mathrm{cc} . \\
6 \mathrm{cc} . \\
2-\mathrm{cc} . \\
7.5 \mathrm{cc} \\
14.5 \mathrm{cc} \text {. } \\
6 \mathrm{cc} .\end{array}$ \\
\hline
\end{tabular}

Piche evaporimeters. The Piche evaporimeters at stations (1) and (2) gave the following total results:

\begin{tabular}{|c|c|c|c|}
\hline Date & Hours & Station 1 & Station \\
\hline 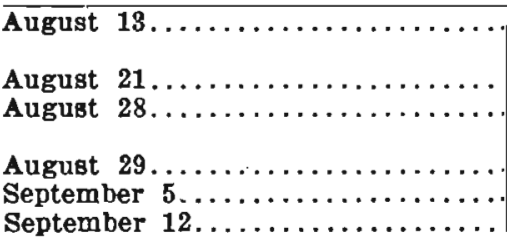 & $\begin{array}{l}6 \text { A. M.-7 P. M. } \\
7 \text { P. M.-6 A. M. } \\
7 \text { A. M.-7 P. M. } \\
4 \text { P. M.-7 P. M. } \\
7 \text { P. M.-7 A. M. } \\
7 \text { A. M.-7 P. M. } \\
7 \text { A. M.-7 P. M. } \\
7 \text { A. M.7 P. M. }\end{array}$ & $\begin{array}{l}.34 \text { cu. in. } \\
.045 \mathrm{cu} \text {. in. } \\
.30 \mathrm{cu} \text {. In. } \\
.08 \mathrm{cu} \text {. in. } \\
.015 \mathrm{cu} \text {. in. } \\
.485 \mathrm{cu} \text {. in. } \\
.45 \mathrm{cu} \text {. in. } \\
.675 \mathrm{cu} \text {. in. }\end{array}$ & $\begin{array}{l}.14 \text { cu. in. } \\
.04 \text { cu. in. } \\
.135 \text { cu. in. } \\
.025 \text { cu. in. } \\
.015 \text { cu. in. } \\
.22 \text { cu. in. } \\
.22 \text { cu. in. } \\
.31 \text { cu. in. }\end{array}$ \\
\hline
\end{tabular}


The Relative Humidity of the air varied at the several stations as indicated in the following table:

\begin{tabular}{|c|c|c|c|c|c|c|c|c|c|c|c|c|c|c|c|c|}
\hline \multirow[b]{3}{*}{ Hour } & \multicolumn{4}{|c|}{ August 21} & \multicolumn{4}{|c|}{ August 29} & \multicolumn{4}{|c|}{ September $\mathbf{5}$} & \multicolumn{4}{|c|}{ September 12} \\
\hline & \multicolumn{4}{|c|}{ Station } & \multicolumn{4}{|c|}{ Station } & \multicolumn{4}{|c|}{ Station } & \multicolumn{4}{|c|}{ Station } \\
\hline & 1 & 2 & 3 & 4 & 1 & 2 & 3 & 4 & 1 & 2 & 3 & 4 & 1 & 2 & 3 & 4 \\
\hline 7 & .79 & .82 & .80 & & & & & & & & 88 & & & & & \\
\hline 8 & .75 & .78 & & .7 & .83 & .83 & .80 & & .86 & .88 & .90 & .82 & .68 & .70 & .63 & .59 \\
\hline 9 & & & & & .74 & .78 & .72 & & .82 & .84 & .75 & .7 & .54 & .56 & .55 & .63 \\
\hline 10 & .62 & .66 & .59 & .58 & .70 & .72 & .70 & & .72 & .79 & & .7 & & .57 & .51 & .51 \\
\hline 1 & & & & & & .58 & .57 & & & & & & & .53 & & .45 \\
\hline 12 & .56 & .62 & .51 & .57 & .50 & .54 & .50 & .47 & .59 & .63 & .58 & & .48 & .51 & & .44 \\
\hline & .57 & .60 & & & & & & & & & & & & & & \\
\hline $\mathbf{2}$ & .57 & .56 & .61. & .64 & .52 & .52 & .53 & .5 & .45 & .46 & .43 & & .33 & .37 & & .37 \\
\hline$?$ & .66 & .67 & .61 & .6 & .4 & .5 &. & & .4 & .4 & & & & & & .38 \\
\hline & & .66 & .58 & .68 & & .58 & & & .4 & .4 & & & .35 & & & .40 \\
\hline & .61 & .72 & & & .52 & .58 & .5 & .6 & .47 & .52 & .46 & & 9 & .39 & .40 & .50 \\
\hline & .7. & .72 & .68 & .78 & .59 & 3 & .6 & & & .5 & .6 & & .41 & .47 & .43 & .47 \\
\hline & & .74 & .68 & .81 & .72 & .70 & .72 & .7 & & & & & .43 & .45 & .43 & .53 \\
\hline
\end{tabular}

The psychrometric record for August 13th is incomplete, and is omitted.

The foregoing results show clearly that evaporation is much more rapid in the exposed prairie areas.

The relation which meteorological conditions bear to evaporation is well illustrated by the results which were obtained at station (1) and represented in part graphically in plates XL and XLI. Each of the figures on these plates presents three curves: The full line (A) represents the amount of evaporation from a Piche evaporimeter, measured in tenths of a cubic inch, the latter forming the ordinates of the curve; the broken line $(B)$ represents the velocity of the wind in miles per hour, the latter forming the ordinates of the curve; and the dotted line (C) 'represents the temperature in Fahrenheit degrees, the latter also forming the ordinates of the curve.

In all cases the hours of the day between $70^{\prime}$ 'clock A. M. and 7 o'clock P. M. form the abscissas of the curves, each space representing one hour.

The numbers $0,2,4,6,8,10,12$ and 14 on the left hand side of each figure represent wind-velocity in miles per hour; the corresponding decimals represent evaporation from the Piche 


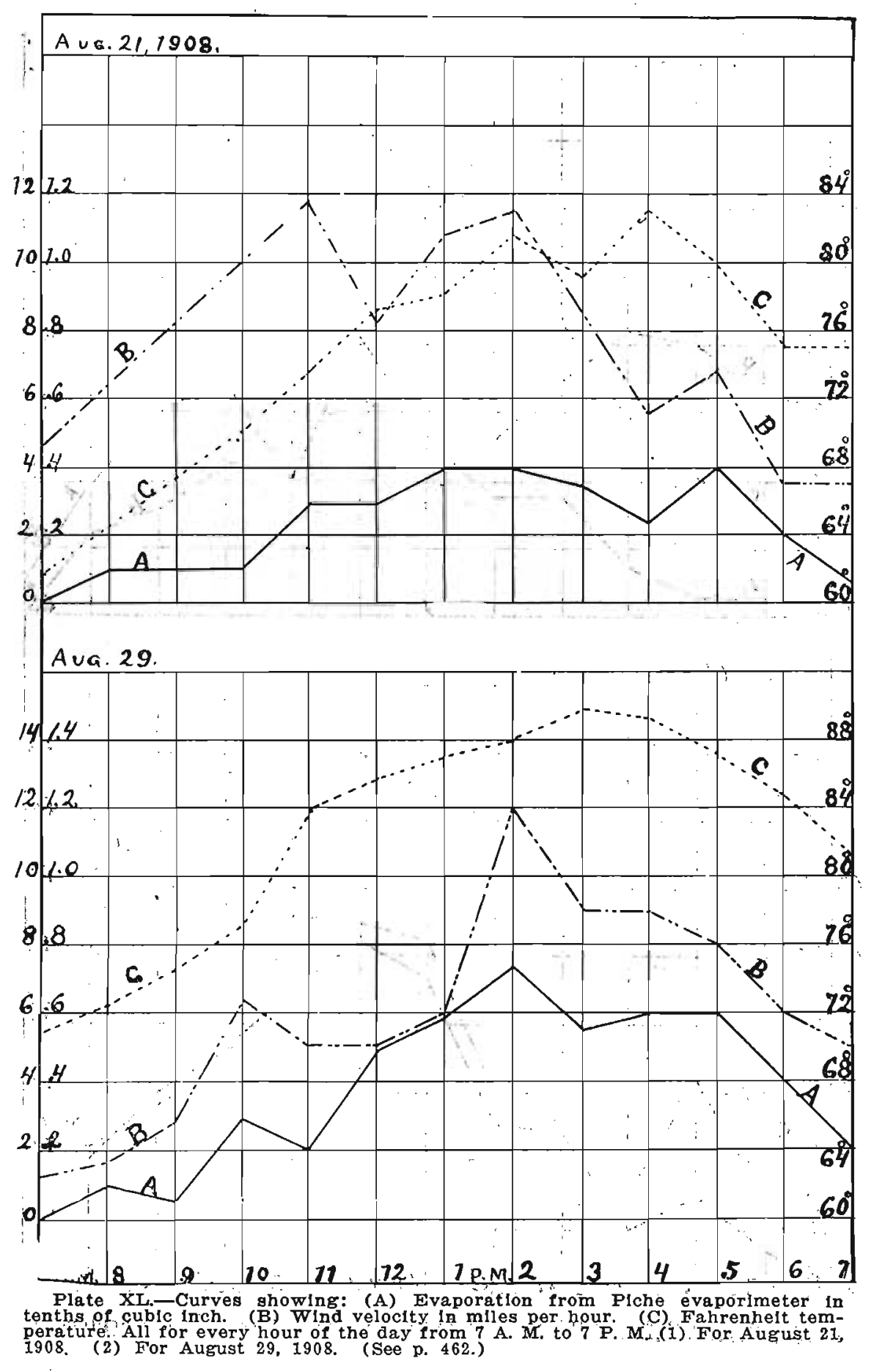




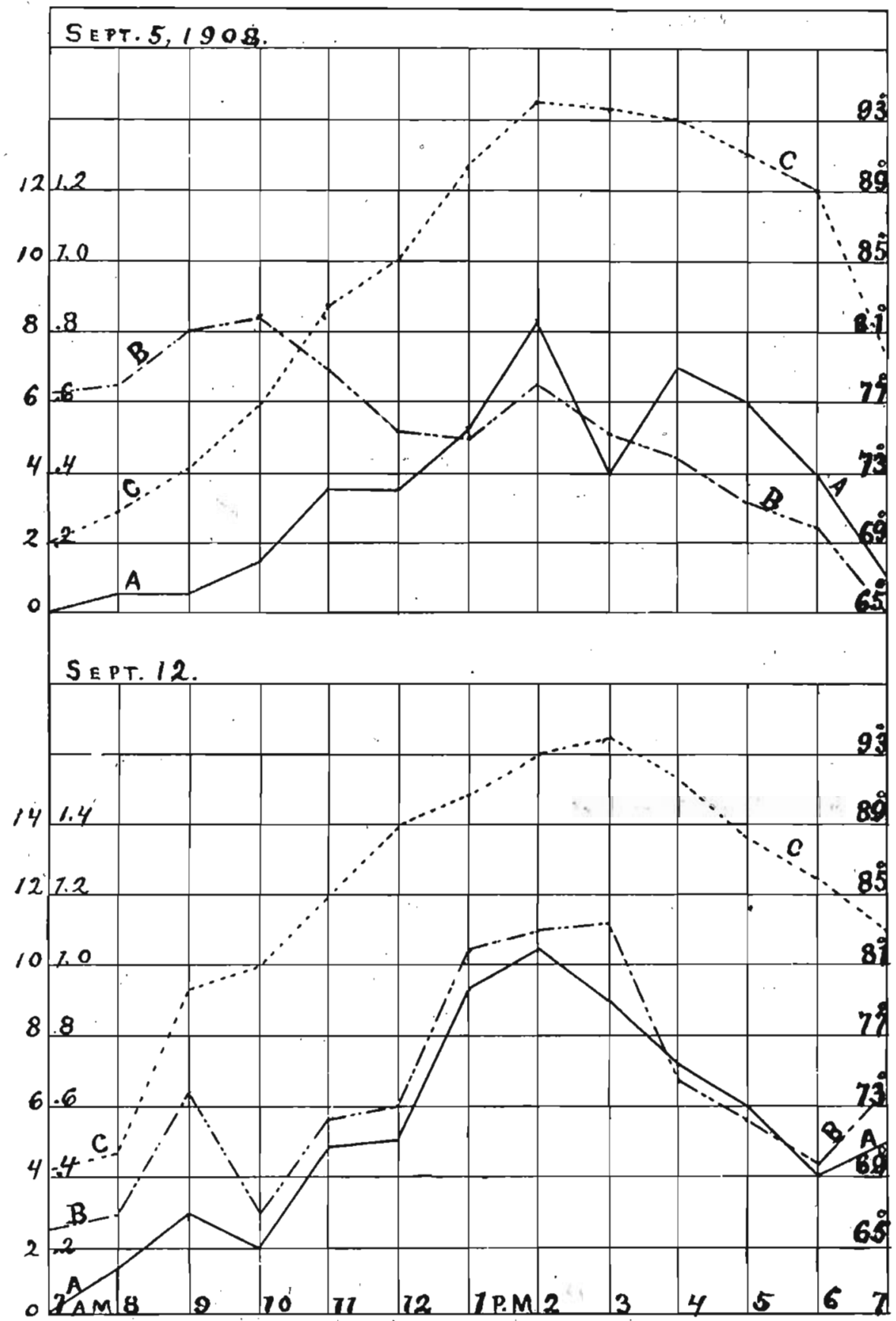

Plate XLI.-Same as plate XL. (1) For September 5, 1908 . (2) For September 12, 1908. (See p. 462.) 
evaporimeter measured in tenths of a cubic incli; and the degrees Fahrenheit are indicated on the right hand side of each figure.

A striking relation between evaporation and wind velocity is shown by these figures. While the temperature curve is in most cases comparatively regular the curves representing wind velocity and amount of evaporation are more or less irregular, but correspond closely to each other in their irregularities. This is especially noticeable in the afternoon when both wind and sun are most effective. The close relation between wind velocity and evaporation is more pronounced as the day advances, and it also became more striking as the dry season advanced and the relative humidity of the air diminished.

An inspection of the relative humidity table for station (1) shows the following variation:

\begin{tabular}{|c|c|c|c|}
\hline & Minimum & Maximum & Average \\
\hline August. & $\ldots . .57$ & .79 & .65 \\
\hline August 29 & $\ldots . .47$ & .86 & .62 \\
\hline September & $\ldots .44$ & .88 & .62 \\
\hline September & $12 \ldots \ldots \ldots \ldots \ldots \ldots \ldots$ & .68 & .44 \\
\hline
\end{tabular}

Rains were frequent during the first half of August, but very little rain fell between the foregoing dates.

The curve for September 5th also shows that both wind and temperature must operate together to cause the maximum evaporation, for on this day the wind was quite brisk early in the morning, yet evaporation was slow until the temperature had increased sufficiently to induce great evaporation, the function of the wind evidently being the removal of the vapors as fast as they are formed thus making room for more. In the same connection it is interesting to compare the amount of evaporation at night and in the day time. It will be observed that at night evaporation at the several stations was more nearly the same than in the daytime, for the exposure of the several stations was then more nearly equal, the sun laving disappeared and the wind having died down.

The foregoing facts suggest an explanation of the presence of dry prairies on southwesterly slopes, for these slopes are not only exposed to the prevailing southwesterly winds of summer but also to the "two-o'clock sun" which produces the maximum temperature and the minimum humidity of the air. 
The clearness of the sky did not vary sufficiently to bring out any striking results. The record for the several observation days is briefly summarized as follows:

August 13. Hazy.

August 21. Hazy A. M.; cloudy P. M.

August 29. Cloudy A. M.; hazy P. M.

September 5. Clear but quite hazy.

September 12. Clear but somewhat hazy.

The direction of the wind for the same days varied as follows:

August 13. Northwest.

August 21. Mostly southwest.

August 29. Southeast A. M.; south P. M.

September 5 . Southeast, then south, then southwest; at 3 o'clock P. M.,

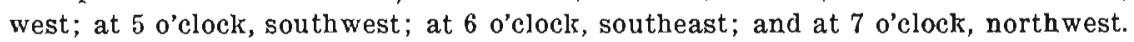
September 12. Southeast, then southwest, then southeast.

The barometric pressure at Station (1) varied as follows (measured in inches) :

- August 13. 28.97 to 28.88 A slight rise and then a gradual fall.

August 21. 28.79 to 28.75 A gradual fall.

August 29. 28.70 to 28.75 Somewhat irregular.

September 5. 28.72 to 28.68 Somewhat irregular.

September 12. 28.96 to 28.84 Somewhat irregular.

Relative humidity curves were not included in the figures on plates XL and XLI, for fear of causing confusion. These curves may be easily constructed by using the relative humidities recorded in the table as ordinates and the hours of the day as abscissas. For this purpose the lowest line in each figure should be marked respectively $.56, .49, .43$ and .31 and each vertical space should represent .06 . Curves so constructed will correspond quite closely with the evaporation curves, being of course their reverse.

The conclusions reached from these observations may be briefly stated as follows: That evaporation is most rapid from surfaces exposed to the prevailing summer winds and to the afternoon sun, and that both are necessary to cause maximum evaporation; that in rough territory these surfaces are chiefly southwesterly and hence exposed as stated, and this at the time of the day when the relative humidity of the air is the lowest; that the effect of wind upon evaporation is best brought out and is greatest when the temperature is sufficiently high to produce rapid evaporation; that evaporation varies with the di- 
rection of the wind and the position of protective barriers such as ridges; and finally that upon all the areas exposed to maximum evaporation a prairie flora, largely xerophytic, is developed, while the mesophytes of the grove and forest develop in our territory only in places sheltered from the chief evaporating agencies.

Similar observations which were made during the same period at Council Bluffs and Omaha confirm these conclusions. A station was established at Council Bluffs, Iowa (on the east side of the Missouri valley) on a dry prairie ridge northeast of the Ninth avenue entrance to Fairmount Park, at an altitude of about 140 feet above the bottoms. This station was fully exposed to the south, southwest, west and northwest.

Another station was located at the same elevation near the intersection of Woolworth avenue and Sixth street in Omaha, Nebraska. This station was located on the rounded western bluffs on a slope looking northeast, and was well exposed to the north, northeast and southeast. This slope was formerly timbered but is now almost bare. This station was in charge of Mr. Lumir Buresh of the Omaha High School whose patient care and perseverance made the double observations possible, the writer taking charge of the station on the east bluff.

On the 17th of August the observations on the west side were made at another station located in a clearing on the timbered bluffs above Florence, Nebraska, all the readings for that date being made at this station. The Florence station was also about 140 feet above the river valley. All the other west side observations were made at the Woolworth avenue station.

The work was conducted in the same manner as at Missouri Valley, excepting that no evaporating pans were used.

The relative rate of evaporation on the opposite sides of the valley is shown in the following summary:

\begin{tabular}{|c|c|c|c|c|c|}
\hline \multirow[b]{2}{*}{ Date } & \multirow[b]{2}{*}{ Time } & \multicolumn{2}{|c|}{ Piche Evaporimeter } & \multicolumn{2}{|c|}{ Cup Evaporimeter } \\
\hline & & $\begin{array}{c}\text { Council } \\
\text { Bluffs }\end{array}$ & Omaha & $\begin{array}{l}\text { Council } \\
\text { Bluffs }\end{array}$ & Omaha \\
\hline $\begin{array}{l}\text { August } 17 \ldots \ldots \ldots \\
\text { August } 30 \ldots \ldots \ldots \\
\text { September } 6 \ldots \ldots \\
\text { September } 13 \ldots \ldots\end{array}$ & $\begin{array}{l}7 \text { A. M. to } 7 \text { P. M. } \\
12 \text { M. to } 7 \text { P. M. } \\
10 \text { A. M. to } 7 \text { P. M. } \\
12 \text { M. to } 7 \text { P. M. }\end{array}$ & $\begin{array}{l}.36 \mathrm{cu} \text {. in. } \\
.41 \mathrm{cu} \text {. in. } \\
.39 \mathrm{cu} \text {. in. } \\
.32 \mathrm{cu} \text {. in. }\end{array}$ & $\begin{array}{l}.10 \mathrm{cu} . \text { in. } \\
.24 \mathrm{cu} . \text { in. } \\
.37 \mathrm{cu} \text {. in. } \\
.27 \mathrm{cu} . \text { in. }\end{array}$ & $\begin{array}{l}43 \mathrm{cc} . \\
38 \mathrm{cc} .\end{array}$ & $\begin{array}{l}24 \mathrm{cc} . \\
10 \mathrm{cc} .\end{array}$ \\
\hline
\end{tabular}


The direction of the wind on the same dates was as follows:

August 17. North and northeast.

August 30. South and southeast.

September 6. North, northeast and northwest.

September 13 . Southeast.

The greater relative evaporation on the west side on September 13th was evidently. due to the fact that the station was exposed to the southeast wind during the entire day, whereas the Coun. cil Bluffs station was sheltered.

The apparent great discrepancy between the Piche and cup evaporimeters on September 6th was evidently due to the circumstance that at the Omaha station the Piche evaporimeter was exposed to the sun while the cup evaporimeter was in the shade during most of the afternoon.

The observations already noted which were made at Ute by Mr. David H. Boot, and those made by the writer in the vicinity of the Lakeside Laboratory at Lake Okoboji in the summer of 1909 , also confirm the general conclusions based on the observations made at Missouri Valley.

It is now necesary to consider the application of these results to our problem. The prairie areas are uniformly so situated that they are fully exposed to the factor's which cause rapid evaporation, namely the sun and the wind. During much of the year they may present conditions quite favorable to plant growth, but there are seasons and there are portions of the year, especially in midsummer, when evaporation and consequent dessication become so extreme that only those plants which are especially adapted to dry regions can survive. The more or less frequent recurrence of such periods which are fatal to the mesophytes of the forest is sufficient to wipe out or rather prevent the development of a forest flora on those surfaces which are most exposed to evaporation. Forest trees are perennial and must exist through all the varying conditions of succeeding seasons. Any period, no matter how short, which is fatal to trees is sufficient to prevent the development of a forest even though the greater part of each season be favorable to tree-growth, and the failure of the trees of course results in the failure of the minor forest flora which in our territory is essentially mesophytic. 
Moreover it should be remembered that trees are tall and lift the transpiring leaf surfaces to a considerable height. In this position the leaves are not only more exposed to the direct rays of the sun, but they are much more exposed to strong winds.

The well-known fact that wind-velocity increases with height above the ground which was demonstrated by Stevenson* and has been frequently verified since, increases the danger to taller plants and makes more difficult the development of forest trees. This increased exposure to evaporation at greater heights should also be kept in mind when comparing the results of the observations at Missouri Valley, for evaporation was there determined at or near the surface of the ground, therefore in positions most favorable to dry areas.

It should not be assumed, however, that increased evaporation necessarily means greater loss of water by the plant. Experiments which are now being conducted in the plant physiology laboratory in the State University of Iowa indicate that transpiration is stimulated and increased by somewhat greater wind velocity, but that when the velocity is increased beyond a certain maximum, which is variable for different plants, transpiration is diminished, the activity of the plant being evidently checked by the violence of the wind. The increased loss of water at the optimum velocity must not be set down as disadvantageous to the plant, for it merely indicates greater vigor and activity on the part of the plant.

However a limit must be reached, and moreover where hot, dry winds blow almost constantly, as they do in summer during the daytime in our territory, the loss of water from the unprotected younger structures and the interference with the stomatal apparatus which to some extent controls transpiration, must ultimately result in the elimination of all plants which cannot well resist these conditions.

This limits the flora of these exposed areas largely to xerophytes, and it is a fact especially worthy of note; and one which will be set out in detail in the near future, that the flora of the prairies, especially that of the usually dry midsummer period; is decicledly xerophytic. This is further emphasized by the sim-

"Nournal of the Scot. Meteorological Society, New Series, vol. v, 1880, p. 348. Also cited in Schimper's Plant Geography (English edition), 1903, p. 76 . 
ilarity of the floras of the prairie and the xerophytic sand-dune areas, the plants of the latter being with very few exceptions identical with those of the dry prairie. That they are serophytic is revealed in the tufted habit, as illustrated in figure 34; the development of large root-systems and the stunting of the exposed tops; the development of thick cutin, deep-seated stomata and strong protective tissues; the production of hairs and scales on the exposed surfaces; and various other adaptations which are recognized as essential to the protection of plants growing on dry surfaces. Hence the structurally protected xerophytes of the prairie persist in exposed places while the mesophytes of the forest fail, and any cause or combination of causes tending to bring about xerophytic conditions will eliminate mesophytes and give the field to the xerophytes of the prairie.

Rainfall should receive attention in connection with evaporation, but it is here given but little prominence as a factor in determining the treelessness of the prairies for the reasons first, that it is entirely sufficient for forest growth within our territory, as shown by Mr. Stern's table, and indeed it is sufficient throughout the prairie sections of the Mississippi valley, if only properly distributed, and second that it cannot be a determining cause because frequently, as illustrated by several of the figures, prairie and forest are in close proximity, upon opposite sides of the same ridge, where they evidently receive the same amount of rain.

The conclusion is therefore inevitable that the question is one of conservation rather than precipitation of moisture, and the claim usually made by meteorologists that forests have no effect on precipitation has no significance in connection with our problem, nor has it any application to the question of the influence of the forest on moisture, for the forest must be considered as a conservator of moisture rather than a rain-maker.

Moreover it must be remembered that a tree, or any other ordinary plant, is quite as much dependent for the possibility of carrying on its functions on the moisture of the air as it is on the moisture of the soil, and any conditions which serve to dissipate the moisture of the air will be fatal to many plants, espe- 
cially those which are mesophytic, even though sufficient moisture falls apon the soil.

\section{CONTRIBUTING CAUSES OF PRAIRIES}

In the extensive literature of the subject the treelessness of the prairies has been attributed to various causes. It is not purposed here to enter into a detailed discussion of the influence of the various factors which have affected the problem as that is reserved for a more extended paper on the subject now in print, but a brief review of the chief causes which have been presented in explanation of the phenomenon may be of interest.

Fire.-This has been the most widely accepted cause of the prairies, and was offered by R. W. Wells as early as 1818* and has been accepted by a large number of writers since. To those who still recall the magnitude and the fury of prairie fires this may seem a plausible explanation, for trees would be injured or killed and seedlings would be destroyed, making the perpetuation of the forest impossible.

It is much more probable, however, that such fires were possible because of the treelessness of the prairies and the consequent annual development of a compact crowded mass of vegetation which furnished abundant fuel to the flames.

While no doubt locally effective, this factor does not explain the general phenomenon. Many tracts still uncultivated have been free from the scourge of fire for thirty or forty years, yet they have not developed groves. The testimony of some of the oldest settlers in Harrison and Monona counties agrees that there has been a denser growth developed in the limited natural groves of the territory since the cessation of fires, but that there has been little or no lateral extension of the groves, nor have any new groves appeared except where set out by man. The native groves still seek the sheltered slopes and valleys as of yore.

Moreover fires do not explain the absence of trees and the presence of a prairie flora in the oak openings already described, as it would be impossible to conceive of the frequent recurrence of fires on these limited areas in the heart of the forest which

\footnotetext{
* Americán Journal of Science and Arts, Series I, vol. 1, pp. 332 and 333.
} 
remain prairie to the present day. Nor do they explain the absence of trees and the presence of the prairie flora on sand-dune areas which do not as a rule produce a sufficient amount of vegetation to feed such fires.

Fires cannot be regarded as more than a local modifying factor.

Excess of moisture.-Excess of moisture, especially in undrained places, is fatal to most trees, and this was regarded as an important factor in prairie-formation and was advanced as early as 1820 by Bourne," who thought that prairies were due to excess of water and the barrens to fires. This seemed especially plausible in such regions as the Wisconsin drift area in the north-central part of Iowa where large undrained areas appeared upon the general prairie. But this explained the absence of trees from the prairie swamps and not from the higher prairie, and certainly not from the oak barrens nor from the prairie ridges of our territory.

Old lake-beds. - The same thought was carried a little farther by those who advanced the theory that the whole prairie region was once a great lake, a theory which was consistent with the lacustrine hypotlesis of loess-formation. The lake theory was offered by $J$. D. Whitney in $1858,+$ and was favored by many geologists. It was especially urged by Lesquereaux $\neq$ and by Alexander Winchell.\$

This theory also fails to explain the types of prairie mentioned under the preceding head and is entirely inconsistent with the rolian hypothesis of loess-formation, a fact of special importance because much of the prairie occurs upon loess.

Old sea-bottom.- In his discussion of the prairies of Alabama W. W. McGuire expressed the opinion that the prairies of that region were formed by the sea. Whatever may be the relation which the areas here designated as prairies bear to our northern prairies it is certain that the latter were not formed by the sea,

*American Journal of Science and Arts. Series I, vol. ii, p. 36.

tSee Hall's Geological Survey of Iowa, vol. i. p. 25.

†Geological Survey of Jllinois, vol. i, $1866, \mathrm{pp} .23 \mathrm{~S}-254$

sAmerican Joumal of bience and Arts; Series II, vol. xxxvii IS64, p. 332: and Centennial History of Mason County, Jlinois, 1876, pp. 67-73.

tomerican Journal of Science and Arts series I, vol, xxvi 1834, pp. 93-28. 
for glacial, fluviatile and æolian formations have been deposited in our territory since it was elevated above the sea.

Lack of moisture. - In direct opposition to the preceding views are those which were held by those who attempted to account for the prairie on the ground of insufficient moisture. Here were included the references to insufficient rainfall to which attention has already been given, and here may be included the conclusions reached in this paper.

Temperature.-Temperature alone has not been regarded as an important factor excepting in so far as it affects humidity, and also because a high temperature tends to bring out buds earlier on southern slopes and thus exposes them to late frosts. The latter, however, is of greater importance in its relation to cultivated trees. Native groves did not ordinarily develop on southerly slopes and temperature could not have therefore produced the stated effect.

Glacial action.-Various attempts have been made to connect the prairies more or less directly. with glacial action, but this explanation encounters an insurmountable obstacle in the presence over large parts of our prairies of an æolian loess deposit which was evidently interglacial or postglacial, and in the presence of prairie on comparatively modern alluvial plains.

Geological formations.-Numerous efforts have been made to show some relation between the prairies and surface geological formations, but as has been noted prairies occur on all the geological formations which come to the surface in the upper Mississippi valley, and geological formations seem to affect the problem only as they determine topogxaphy or the kind of soil.

Soils.-Soils have been closely. associated with the preceding factor and much importance has been attached to them. But prairies appear upon all of our soil types, and soils seem to influence the formation of prairie only when their physical composition facilitates run-off or evaporation.

Wind.-Wind alone has been considered a factor of much importance in prairie-formation but the facts presented in this paper demonstrate that it is effective only when acting with a high temperature.

Cattle and bison.- Some importance has been attached to the 
earlier effects produced by the tramping and grazing of great bison herds, and later to over-grazing, but these are usually regarded as merely local.

Not one of the foregoing factors can account for the prairies in their various aspects, nor can the combination of all of them explain all the phases of these treeless tracts. Exposure to evaporation and a common flora seem to be the only universal characteristics, and Harrison and Monona counties furnish a fair share of evidence to the effect that exposure to evaporation is the dominant cause of the prairie and that the prairie flora is the response to the conditions produced by this exposure.

\section{Tree-Planting.}

The conclusions concerning the cause of the treelessness of the prairies might make it appear that all attempts at tree-cultivation in the prairie sections must ultimately fail. It is extremely probabie that if left to themselves the trees which have been set out on the prairies would fail excepting possibly where large groves have been set out. The usual fate of isolated trees (excepting the cotton-wood, which thrives alone) and the failure of many of the groves in the dry seasons of the middle nineties warn us that the prairie is quite as illy adapted to tree growth as ever, and that trees will succeed only when planted in larger groves and given proper care. For the conditions on the prairies are so near the border line that with proper care and attention man may throw the balance in favor of the trees and cultivate them successfully where they would fail naturally.

That forest trees will grow on the prairies of Harrison and Monona counties is amply demonstrated by the numerous groves and shelter-belts which are scattered over the landscape, and by the numerous shade-trees cultivated in the towns and along the highways.

The most common trees in the groves and shelter-belts are the box-elder, soft maple, cottonwood, green ash, walnut, catalpa, Scotch pine, Austrian pine, and red cedar. The first five and the last one are native. Willows are also sometimes planted for shelter-belts:

For shade and ornamental purposes the following species are 
most commonly planted in addition to those already mentioned: the American elm, red elm, black cherry, mulberry, hackberry and honey locust among native species, and the black locust; hard maple; mountain ash, white pine, balsam, Norway spruce, hemlock, arbor vitæ and other introduced species.

Most of these species require the protection of shelter-belts and for this purpose the species of the first list are suitable.

The people of the western part of the state owe a debt of gratitude to one of the old settlers of Monona county, Hon. C. E. Whiting, who not only by word but by example taught them that trees would thrive upon the prairies, and who transformed his homestead, northeast of Whiting, and its vicinity from a monotonous prairie to a region sheltered and made beautiful by splendid groves; for not only did he himself plant extensively but he inoculated his neighbors with the desire to do likewise. No grander monument stands today in our state than that which Judge Whiting erected to himself in the magnificent groves and shelter-belts which stand as evidence of his wisdom and foresight.

A brief record of these groves, furnished by his daughter, Mrs. Charles Holmes, will be of interest.

The first grove was set out in 1865. It is located near the old homestead, one of the finest country homes in Iowa, in the northeast corner of section 25 , township 85 north, range 46 west, and consists largely of soft maples. The seed was planted in the spring of 1865 , and the trees were cultivated like any other ordinary crop. These soft maples now vary from eight to seventeen inches in diameter, and form a dense forest from which all traces of prairie plants have disappeared though the grove was set out on the open prairie. In the shelter of this grove practically all the shade trees listed were planted and they have prospered remarkably well, adding greatly to the beauty of the home.

It is interesting to note that the original prairie flora has here been entirely replaced by a typical forest flora which has been developed notwithstanding the fact that all the trees in the grove were grown from seed.

The following grouping of plants found in the grove will suggest the manner of introduction. 
FRUTTS MORE OR LESS FLESHY.

Evonymus atropurpureus Jacq. Wahoo.

Fragaria virginiana Duches. Wild Strawberry.

Menispermum canadense L. Moonseed.

Morus rubra L. Mulberry.

Psedera quinquefolia (L.) Greene. Virginia Creeper.

Rhus toxicodendron L. Poison Ivy.

Ribes gracite Michx. Wild Gooseberry.

Rubus occidentalis L. Wild Raspberry.

Sambucus canadensis L. Common Elder.

Vitis vulpina L. Wild Grape.

FRUIT CARRIED BX WIND.

Acer negundo L. Box Elder.

Eupatorium purpureum L. Purple Boneset.

Eupatorium urticaefolium L. White Boneset.

Fraxinus pennsylvanica var. lanceolata. (Bookh.) Sarg. Green Ash.

Lactuca floridana (L.) Gærtn.

olmus americana L. White Elm.

TRUYT BUR-LIKE.

Arctium minus Bernh. Burdock.

Galium aparine L. Bed-straw.

Lappula virginiana (L.) Greene. Beggar's Lice.

Sanicula marilandica Michx. Black Snake-root. SEEDS EATEN BY BIRDS. (?)

Amphicarpa monoica (L.) Ell. Hog Peanut.

Zanthoxylum americanum Mill. Prickly Ash.

MISCELLANEOUS SEEDS-SMALL, LIGHT.

Cryptotaenia canadensis $\mathrm{L}$.

Plantago Rugelii Dec. Plantain.

Urtica gracilis Ait. Nettle.

ABTIFICIALLY PLANTED.

Acer saccharinum L. Solt Maple.

Juglans nigra L. Black Walnut.

Pinus strobus L. White Pine.

Pinus sylvestris L. Scotch Pine.

The fleshy and edible fruits were probably carried by birds from the native groves along the Missouri or the Little Sioux; the light or winged fruits were carried by the wind; the burlike forms were carried by animals or man; and some of the light miscellaneous forms may have been driven along the surface of snow in winter. 
It is worthy of note that with the exception of some of the trees which were set out by Judge Whiting, and the burdock which is an introduced weed, the plants are all native and belong to the forest flora. Yet the nearest natural grove is several miles away.

This complete change of flora illustrates how different are the habits and requirements of the forest and prairie floras.

The second grove was planted along the north line of the northeast quarter of the same section just west of the first grove. This consists largely of cottonwoods which were set out in 1866, seedlings from the Missouri bars being used.

Some of the cottonwoods are older, having been planted in the early sixties, and walnuts were planted later, seed which had been covered with earth all winter being used.

The third grove was planted in 1867. It is located on the north line of the same section and forms a continuous grove with the two preceding groves. It consists of walnuts which were treated as before.

The fourth grove consists chiefly of walnut which was set out in 1869. It is located along the north line of the northeast quarter of the northwest quarter of the same section.

The fifth grove was set out in 1870, and consists of soft maple. Seed collected along the Little Sioux was used. This grove is located in the northwest quarter of section 30, township 85 north, range 45 west.

The sixth grove consists chiefly of walnut and was planted in 1871. It is three-quarters of a mile long and lies along the south line of the north half of section 25. There are a few old cottonwoods in this grove.

The seventh grove is nearly a mile and a half long and extends along the north line of section 30 and the north line of the northwest quarter of section 29, township 85 north, range 45 west. The grove is about fifteen rows wide and the rows are mostly about five feet apart. This grove or shelter-belt consists of green ash, soft maple, walnut and cottonwood, and excepting where injured by stock, or where too closely crowded, the trees are thrifty.

Not only did Judge Whiting thus demonstrate the possibility 
of growing trees successfully on the prairies, but he gave the benefit of his experience to others, for he published numerous reports of his experiences in the government agricultural reports and in the Reports of the Iowa Horticultural Society. The latter contains a number of articles which might well be read with profit by those who are recklessly cutting away their groves and shelter-belts. The more important of these papers are the following:

Tree and Timber Culture. First Annual Report, 1867, pp. 43-45.

Cottonwoods, pp. 125-126; and Timber growing, pp. 197-200; both in the Eighth Report for 1873.

Value of the Black Walnut. The Report for 1880 , pp. 379 and 380 .

How far is it profitable to plant timber belts for protection? The same Report, pp. 297-299.

In the last paper Judge Whiting made a statement which should receive the attention of every farmer in the state. It is as follows: "Timber-belts for the protection of crops alone will pay."

This statement, made by a man who had greater experience than any other person in the state, is especially significant in the light of the observations made at Missouri Valley. The latter demonstrate that an obstruction which checks the hot summer winds also checks evaporation. Crops suffer from evaporation even more than do ordinary prairie plants and a shelter-belt will check this and assist in conserving the moisture so necessary to the crops. Farmers will yet come to a realization of the fact that it pays to use a strip of even the most valuable land for a shelter-belt where the field is exposed to summer winds, for the gain in the field resulting from the protection given by the shelterbelt will more than compensate in the end for the loss of possible crops on the strip given up to the grove.

As soon as time permits the writer expects to determine quantitatively, if possible, the difference which such an obstruction as the shelter-belt would offer would cause in the amount of evaporation from the adjoining field. That there is a difference the experiments thus far made demonstrate beyond question.

The record of tree-planting in Monona county would not be complete without some reference to the efforts of Judge Addi- 
son Oliver of Onawa. In $1890 \mathrm{Judge}$ Oliver planted 1,500 bushels of walnuts on a tract three-quarters of a mile square in sections 16 and 17 in Franklin township, south of Onawa. The native forest of cottonwood, soft maple and elm had been removed from this tract so far as the timber was serviceable for railway uses, and the walnuts were promiscuously planted on this cutover land. The trees were not cultivated but were permitted to grow without care. Many of the walnuts were destroyed by late frosts when quite young.

Many thousands of black locust, Russian mulberry and catalpa were also planted on the same tract, but the catalpas were all destroyed and few of the Russian mulberries survived. The black locust is regarded by Judge Oliver as the most rapid grower and the best of the hard-wood trees in this section of the state.

Judge Oliver also set out about fifty acres of 'walnuts, cottonwoods and some ash at his old homestead five miles southeast of Onawa. These suffered more or less from fires and neglect. He also planted four strips of walnuts totaling three and a half miles in length and each five rods wide. He also planted diamond willows in low places and regards them as very valuable for fuel.

Many other illustrations of successful tree-planting in our territory might be given, but these splendid examples sufficiently demonstrate that with proper care trees may be profitably grown on the alluvial prairies. That they may also be successfully grown on the uplands is shown by the innumerable groves which dot the hillsides and the upland prairies in both counties.

\section{Weeds.}

Many introduced plants and several native species rank as weeds. They may be only unattractive, giving to roadsides, barnyards, waste places and front yards an unsightly appearance, or they do positive injury by crowding or destroying useful crops in fields and gardens, or by restricting the area of pastures by occupying much space to the exclusion of forage plants.

Most of the foreign weeds were introduced with seeds of cropplants, but some are undobtedly distributed by the railways 
which also assist in the distribution of native weeds. Several native species of plants are sufficiently adaptable to environment to become weeds even on cultivated grounds.

Cutting of weeds before their fruiting season and thorough cultivation of the soil will eliminate, or at least much restrict these pests. However, even such methods are effective only when a concerted effort is made in a large territory. Individual effort avails but little if the weeds of surrounding lands are permitted to grow unchecked.

The laws of the state already provide penalties for failure to eradicate certain weeds, but unfortunately these laws are not self-enforcing. If our citizens realized the magnitude of the loss which our state suffers annually from mere weeds a more effective public sentiment would force closer attention to the problem of weed extermination.

Most of the weeds here listed are widely distributed through Harrison and Monona counties, but in the following list only those localities are specifically mentioned in which specimens were collected. Those marked with an asterisk were introduced.

$$
\text { WEEDS AND INTRODUCED PIATTS. }
$$

*Abution Theophrasti Medic. Velvet Leaf. Local.

* Amaranthus albus L. Not uncommon. Turin, Onawa.

Amaranthus blitoides Wats. In dry places. Missouri Valley, Grant Centel, etc.

* Amaranthus hybriaus L. Pig-weed. Common. Logan, etc.

* Amaranthus retroflexus L. Locally very common. Missouri Valley, Grant Center, etc.

Ambrosia artemisiaefolia L. Ragweed. Very common in waste places along roadsides, etc.

Ambrosia trifida L. Greater Ragweed. Locally common on lower grounds.

* Anthemis cotula L. Dog-fennel. Pisgah, waste places, not common.

Bidens frondosa L. Beggar-ticks. Ute.

*Brassica arvensis (L.) Ktze. Charlock. Very common in fields, etc.

* Brassica nigra (L.) Koch. Black Mustard. Less common than the preceding. Missouri Valley, etc.

*Bromus racemosus L. Missouri Valley, Onawa. Local.

*Bromus secalinus L. Cheat. Fields, local. Missouri Valley, etc.

*Camelina sativa (L.) Crantz. False Flax. Common along railways. California Junction.

*Cannabis sativa L. Hemp. Locally common. Missouri Valley, Logan.

*Capsella bursa-pastoris (L.) Medic. Shepherd's Purse. Waste places. MIssouri Valley, Ute, Grant Center, etc.

Cassia chamaecrista L. Partridge-pea. Locally very common on loess and in sandy places. Missouri Valley, etc. 
Cenchrus carolinianus Walt.; Sand-bur. On loess and sand. Missouri Valley, etc.

*Chenopodium album L. Lambsquarters. Common in gardens and waste places. Logan, Missouri Valley, Turin, Onawa, Grant Center.

*Chenopodium urbicum L. Goose-foot. Less common. Missouri Valley, Turin, Onawa.

Corivolvulus sepium $\mathrm{L}$. Wild Morning-glory. Very common along roadsides, in fields, etc. Missouri Valley, Grant Center, etc.

*Cynoglossum officinale L. Beggar's Lice. Not common. Calhoun.

* Dactylis glomerata L. Orchard Grass. Local. Missouri Valley, Grant Center, etc.

* Datura tatula L. Thorn Apple. Locally common, especially in hog-pastures.

* Daucus carota L. Carrot. Not common. Mapleton.

*Digitaria sanguinalis (L.) Scop. Crab-grass. Common in waste places. Missouri Valley, etc.

Dyssodia papposa (Vent.) Hitch. Fetid Marigold. Very common in dry places. Missouri Valley, Grant Center, etc.

*Echinochloa crus-galli (L.) Beauv. Barnyard-grass. Waste places. Logan, Missouri Valley.

*Eragrostis megastachya (Koel.) Link. Snake-grass. Local. Logan, Ute, etc. Eragrostis pilosa (L.) Beauv. Locally common. Logan, etc.

Erigeron canadensis L. Horse-weed. Very common in waste places. Logan, Blair bridge, Ute, Grant Center, etc.

Erigeron ramosus (Walt.) BSP. Daisy Flea-bane. Very common in meadows, etc. Missouri Valley, Blair bridge, Turin, Onawa, Grant Center, etc.

Euphorbia heterophylla L. Spurge. Not common. Missouri Valley.

Euphorbia maculata L. Locally common. Turin, Onawa, Missouri Valley.

Euphorbia marginata Pursh. Snow-on-the-mountain. Common in dry pastures. Missouri Valley, Turin, Grant Center.

Euphorbia Prestii Schrad. Spurge. Common in dry places. Logan, Missouri Valley, Blair bridge, Ute.

Helianthus annuus L. Sun-fiower. Common. Missouri Valley, Blair bridge, Onawa, Turin, Grant Center.

*Hibiscus trionum L. Flower-of-an-hour. Local. Missouri Valley, Modale.

Hordeum jubatum L. Squirrel-tail Grass. Very common locally. Missouri Valley, Murray hlll, Turin, Ute, Grant Center.

*Ipomoea purpurea (L.) Roth. - Morning-glory. Very common in fields, especially on the alluvial bottoms. Missouri Valley, etc.

Iva xanthiifolia (Fresen.) Nutt. Marsh-elder. Onawa, Grant Center, etc.

${ }^{*}$ Lactuca scariola L. Prickly Lettuce. Common in waste places. Missouri Valley, Turin, Onawa, etc.

Lepidium apetalum Willd. Pepper-grass. Common in dry places. Missour1 Valley, Turin, Grant Center, etc.

*Lepidium virginicum L. Pepper-grass. In waste places. Grant Center, etc.

* Lotus corniculata L. Rare. Mapleton.

* Lychnis dioica L. Red Campion. Not common. Missouri Valley.

Lygodesmia juncea (Pursh) D. Don. Very common on loess hills. Missouri Valley, Logan, Turin, Grant Center.

* Malva rotundifolia L. Round-leaved Mallow. Waste places. Turin, Onawa, Grant Center. 
Martynia louisiana Mill. Unicorn-plant. Reported by Pammel. Rare.

* Medicago sativa L. Alfalfa. Common in waste places. Missouri Valley, etc.

* Melilotus alba Desv. White Sweet-clover. Locally very common. Missouri Valley, Logan, Turin, Onawa, Grant Center, etc.

* Melilotus officinale L. Yellow Sweet-clover. Less common. Missouri Valley, Grant Center.

*Nepeta cataria L. Catnip. Local. Turin, Grant Center, etc.

OEnothera biennis L. Evening Primrose. Common. Missouri Valley, Lugan, Grant Center.

Oxalis stricta L. Yellow Wood-sorrel. Common in fields, etc. Missouri Valley, Turin, Onawa, Ute, Grant Center, etc.

oxybaphus nyctagineus (Michx.) Sweet. Four-o'clock. Local. Missouri Valley, etc.

Oxytropis Lamberti Pursh. Loco-weed. Locally common on dry loess hills. Missouri Valley, Turin, Grant Center.

Panicum capillare L. Old-witch Grass. In fields, etc. Missouri Valley, Grant Center, etc.

Panicum Scribnerianum Nash. Prairie Panic-grass. Common in dry pastures. Missouri Valley, Logan, Turin, etc.

*Phleum pratense L. Timothy. Frequent. Onawa, Grant Center, etc.

Physalis subglabrata Mack. \& Bush. Ground Cherry. Local. Logan.

* Plantago lanceolata L. Plantain. In fields, etc. Missouri Valley, Mapleton. Plantago Rugelii Dec. Plantain. Locally common. Missouri Valley, Ute, etc. Poa pratensis L. Blue Grass. Everywhere common.

* Polygonum aviculare L. Local. Missouri Valley, Grant Center, etc.

* Polygonum erectum L. Local. Missouri Valley, Grant Center.

*Polygonum convolvulus L. Bind-weed. Quite common. Logan, Grant Center, Ute, etc.

*Polygonum orientale L. Prince's Feather. Local. Missouri Valley, Grant Center.

Polygonum pennsylvanicum L. Smart-weed. Common. Missouri Valley, Logan, Modale, Turin, Ute, Grant Center, etc.

* Rumex acetosella L. Sour-dock. Chiefly along railroads. Missouri Valley, Turin.

* Rumex crispus L. Curly-dock. Locally common. Missouri Valley, Grant Center, etc.

Rumex verticillatus L. Dock. Local. Missouri Valley.

* Salsola kali var. tenuifolia G. F. W. Meyer. Russian-thistle. Dry places. Missouri Valley, Logan, Onawa, Grant Center.

* Setaria viridis (L.) Beauv. Green Fox-tail. Common in fields, etc. Missouri Valley, Logan, etc.

* Sisymbrium offcinale L. Hedge Mustard. Waste places and roadsides. Grant Center, etc.

Solanum carolinense L. Horse Nettle. Local. Mapleton, Logan.

*Solanum nigrum L. Black Nightshade. In fields and gardens. Missouri Valley, Grant Center, etc.

* Solanum rostratum. Dunal. Buffalo-bur. Introduced from the southwest. Woodbine. Reported by Pammel.

Solidago rigida L. Stiff Golden-rod. Very common in dry pastures. Missouri Valley, Logan, Turin, Ute, Grant Center, etc. 
-Sonchus asper (L.) Hill. Sow Thistle. Waste places. Logan, Grant Center, etc.

Strophostyles helvola (L.) Britt. Wild Bean. Sandy places. Blair bridge.

Strophastyles pauciflora (Benth.) S. Wats. Wild Bean. On loess and sand. Missouri Valley, etc.

*Taraxacum offcinale Weber. Dandelion. Very common. Missouri Valley, Ute, Grant Center, ètc.

Thlaspi arvense L. Penny-cress. Chiefly along -railways. Little Sioux, Caltfornia Junction.

* Trifolium hybriáum L. Alsike Clover. Becoming very common. Missouri valley, etc.

*Trifolium pratense.L. Red Clover. Common. Missouri Valley, etc.

Trifolium repens L. White Clover. Common. Missouri Valley, Ute, Grant Center, etc.

* Verbascum thapsus L. Mullein. Łocal. Ute, etc.

Verbena bracteosa Michx. Local. Pisgah, Grant Center, etc.

Verbena hastata L. Blue Vervain. Frequent. Missouri Valley, Logan, etc.

Verbena stricta Vent. Hoary Vervain. Very common, especially in prairie pastures, etc. Throughout our territory.

Derbena urticaefolia L. White Vervain. Local. Missouri Valley, Turin, Ute, etc.

Vernonia fasciculata Michx. Ironweed. In low pastures. Missouri Valley, etc.

Vernonia noveboracensis (L.) Willd. Locally common in dry pastures. Missouri Valley, Turin.

Xanthium commune Britt. Cockle-bur. Common in waste places and fields.

Yucca glauca Nutt. Soap-weed. Locally common in dry loess pastures. Turin, Grant Center, etc.

\section{ACKNOWLEDGMENTS}

The writer desires to express especial appreciation to Professor Samuel Calvin, the Director of the Iowa Geological Survey, for the generous support and encouragement which he has given to the work from the very outset, and also for valuable special assistance, some of which is specifically acknowledged in the text.

So generous and so helpful were the people of Harrison and Monona counties in furthering the progress of the survey that it is difficult to make specific acknowledgments, as names of deserving persons are sure to be omitted. The people of these counties are certainly entitled to thanks for their uniform courtesy and willingness to help in the cause, and the writer regrets that he was not able in some cases to accept offers of still further generous help. 
While it is thus difficult to make specific acknowledgments the services rendered by some of the citizens of these counties are so valuable that they should receive special mention.

Valuable plats, maps and other data were liberally furnished by Messrs. J. S. Wattles of Missouri Valley, C. L. Crow, J. C. McCabe and L. C. Brown of Logan, J. B. P. Day of Castana, and Mitchell Vincent of Onawa. These gentlemen not only furnished valuable information based on their engineering experience, but their long time residence in the territory gave them a fund of other helpful information which they freely contributed. Mr. Crow was especially active in securing information of this kind.

Mr. Glenn H. Stern's contribution of the remarkable meteorological record is especially appreciated.

Many persons furnished valuable materials. Special thanks are due to Messrs. Claude Cox of Missouri Valley, W. E. Babcock of Turin and George Peyton of Pisgah to whom the richness of the Aftonian collection of mammals is largely due. Thanks are due for other valuable donations by the Woodbine Normal School; by the Sioux City Academy of Science and Letters; by Messrs. Frank Peckenpaugh, and Lester Adams of Logan; Drs. J. L. and J. H. Tamiesea, and G. F. and G. H. Culavin of Missouri Valley; and Chas. I. Whiting of Mapleton.

Many persons offered desirable information bearing on the work of the Survey or gave assistance in the work, and the following should be specially mentioned in addition to those already enumerated: Messrs A. H. Sniff, C. H. Deur, and J. C. Prather of Missouri Valley; Almor Stern of Logan; Professors M. S. Kinney and M. A. Reed of the Woodbine Normal; Hon. Parker K. Holbrook of Onawa; A. B. Elliott, and George Fischer of Turin; David Tacy of Castana; C. F. Griffin and C. A. Hawthorn of Mapleton; Hon. Will C. Whiting and Charles Holmes of Whiting; and others specially mentioned in the text. Especially valuable information on tree-planting was furnished by Mrs. Charles Holmes of Whiting and Judge Addison Oliver of Onawa. Finally the writer desires to thank Messrs. Lumir Buresh of Omaha, and Levi A. Giddings of Magnolia for their assistance in the trying and tedious work connected with the 


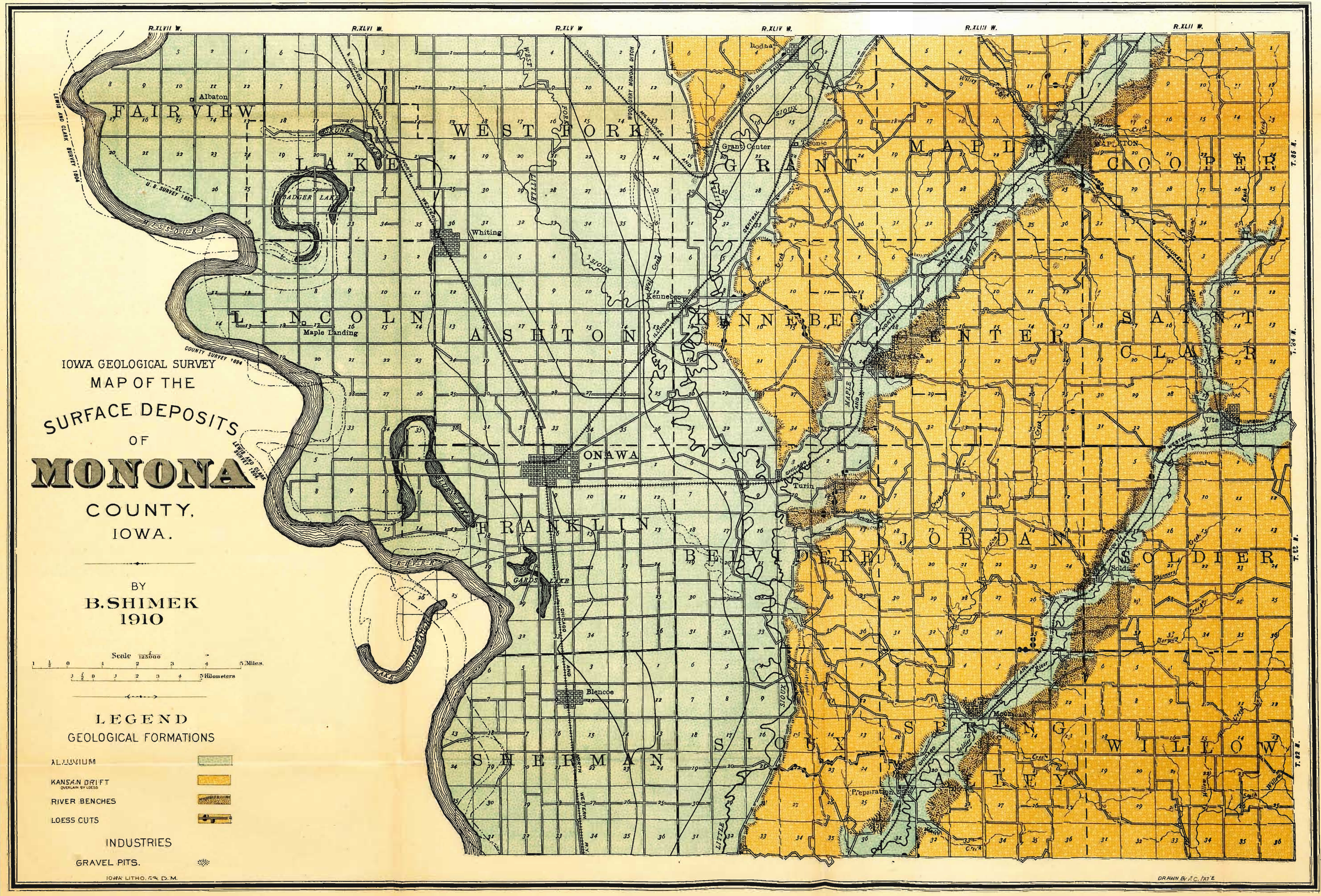


observations on evaporation, and to Mr. David H. Boot who undertook similar observations in the vicinity of Ute.

An acknowledgment should also be made to the Bulletin from the Laboratories of Natural History of the State University of Iowa for the use of cuts for plates XXXVI to XLI inclusive, and for figure 35, and to the Iowa Academy of Sciences for the cuts for figures 31 and 34 inclusive, and figure 36. 
